DEPARTMENT OF THE INTERIOR

UNITED STATES GEOLOGICAL SURVEY

CHARLES D. WALCOTT, DHECTOR

\title{
UNDERGROUND WATERS
}

or

\section{STERN UNITED STATES}

MYRON L. FULLER

GHOLOGIST IN CHARGF

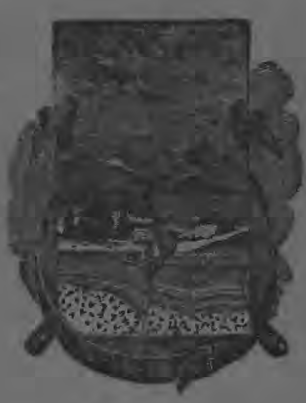

WASHINGTON

GOVERNMENT PRINTING OFFICE

1905 


\section{PUBLICATIONS OF UNITED STATES GEOLOGICAL SURVEY.}

The publications of the United States Geological Survey consist of (1) Annual Reports; (2) Monographs; (3) Professional Papers; (4) Bulletins; (5) Mineral Resources; (6) Water-Supply and Irrigation Papers; (7) Topographic Atlas of the United States, folios and separate sheets thereof; (8) Geologic Atlas of United States, folios thereof. The elasses numbered 2, 7, and 8 are sold at cost of publication; the others are distributed free. A circular giving complete lists may be had on application.

The Professional Papers, Bulletins, and Water-Supply Papers treat of a variety of subjects, and the total number issued is large. They have therefore been classified into the following series: $A$, Economic geology; B, Descriptive geology; C, Systematic geology and paleontology; D, Petrography and mineralogy; E, Chemistry and physicg; F, Geography; G, Miscellaneous; H, Forestry; I, Irrigation; J, Water storage; K, Pumping water; L, Quality of water; M, General hydrographic investigations; N, Water power; 0 , Underground waters; P, Hydrographic progress reports.

The following Water-Supply Papers are out of stock, and can no longer be supplied: Nos.1-16, 19, 20, $22,29-34,36,39,40,48,46,57-65,75$. Complete lists of papers relating to water supply and allied subjects follow. (PP=Professional Paper; $B=$ Bulletin; WS=Water-Supply Paper.)

\section{SERTES I-IRRIGATION.}

WS 2. Irrigation near Phcenix, Ariz,, by A. P. Davis. 1897. 98 pp., 31 pls. and maps. WS 5. Irrigation practice on the Great Plains, by E. B. Cowgill. 1897 . 39 pp., 11 pls. WS 9. Irrigation near Greeley, Colo., by David Boyd. 1897.90 pp., 21 pls. WS 10. Irrigation in Mesilla Valley, New Mexieo, by F. C. Barker. 1898. 51 pp.,11 pls. WS 13. Irrigation systems in Texrs, by W. F. Hutsou. 1898. 68 pp., 10 pls. WS 17. Irrigation near Bakersfield, Cal, by C. E. Grunsky. 1898.96 pp., 16 pls. WS 18. Irrigation near Fresno, Cal., by C. E. Grunsky. 1898. 94 pp., 14 pls. WS 19. Irrigation near Merced, Cal., by C. E. Grunsky. 1899. 59 pp., 11 pls. WS 23. Water-right problems of Bighorn Mountains, by El wood Mead. 1892.62 pp., 7 pls. WS 32. Water resources of Forto Rico, by H. M. Wilson. 1899.48 pp., 17 pls. and maps.

WS 43. Conveyance of water in irrigation canals, fumes, and pipes, by Samuel fortier. 1901. 86 pp., 15 pls.

WS 70. Geology and water resources of the Patrick and Goshen Hole quadrangles, Wyoming, by G. I. Adams. 1902.50 pp., 11 pls.

Ws 71. Irrigation systems of Texas, by T. U. Taylor. 1902. $137 \mathrm{pp}, 9$ pls.

Ws 74. Water resources of the State of Colorado, by A. L. Fellows. $1902.151 \mathrm{pp}, 14 \mathrm{pls.}$

WS 87. Irrigation in India (second edition), by H. M. Wilson. 19r3. 238 pp., 27 pls.

WS 93. Proceedings of first conference of engineers of the reclemation service, with accompanying papers, compiled by F.H. Newell, chief engineer. 1904. $361 \mathrm{pp}$.

The following papers also relate especially to irrigation: Irrigation in India, by H. M. Wilson, in Twelfth Annual, Pt. II; two papers on irrigation engineering, by H. M. Wilson, in Thirteenth Annual, Pt. III.

\section{SERIES J-WATER STORAGE.}

WS 33. Storage of water on Gila River, Arizons, by J. B. Lippincott. 1900.98 pp., 39 pls. WS 40. The Austin dam, by Thomas U. Taylor, 1900.51 pp., 16 pls.

WS 45. Water storage on Cache Creek, California, by A. E. Chandler. 1901.48 pp., 10 pls.

ws 46. Physical characteristics of Kern River, California, by F. H. Olmsted, and Reconnaissance of Yuba River, California, by Marsden Manson. 1901. $57 \mathrm{pp}, 8 \mathrm{pls}$

WS 58. Storage of water on Kings River, California, by J. B. Lippincott. 1902.100 pp., 32 pls.

WS 68. Water storage in Truckee Basin, California-Nevada, by L. H. Taylor. 1902. 90 pp., 8 pls.

WS 73. Water storage on Salt River, Arizona, by A. P. Davis. 1902.64 pp., 25 pls.

WS 86. Storage reservoirs on Stony Creek, California, by Burt Cole. 1903.62 pp., 16 pls.

Ws 89. Water resoarces of the Salinas Valley, California, by Homer Hamlin. 1904, 91 pp., 12 pls,

WS 93. Proceedings of first conference of engineers of the reclamation service, with accompanying papers, compiled by F. H. Newell, chief engineer. 1904.361 pp.

The following paper also should be noted under this heading: Reservoirs for irrigation, by J. D. Schuyler, in Fighteenth Annual, Pt. IV. 


\section{UNDERGROUND WATERS}

\section{EASTERN}

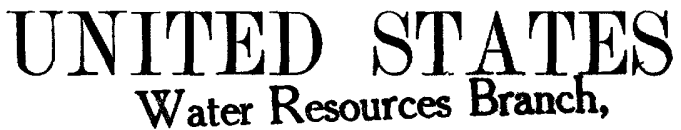

Geological Survey,

Box 3106, Capitol Station Oklahoma City, Okla.

MYRON L. FULLER

GHOLOGIST IN CHARGE

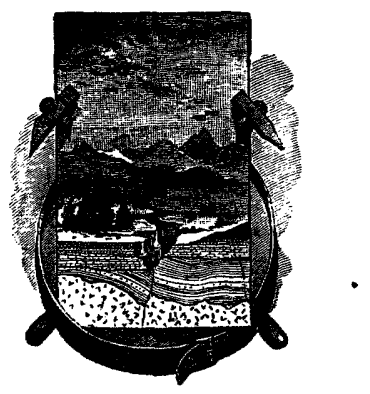

\section{W ASHINGTON}

GOVERNMENT PRINTING OFEICE 1905 


\section{CONTENTS.}

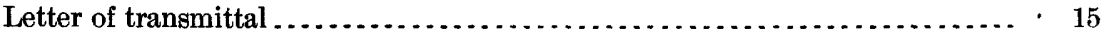

Introduction ....................................................... 17

Occurrence of underground waters, by M. L. Fuller................... 18

Sources of ground water ........................................ 18

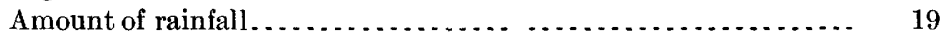

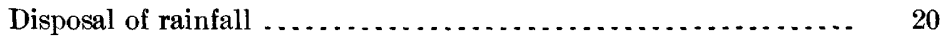

Evaporation ........................................ 20

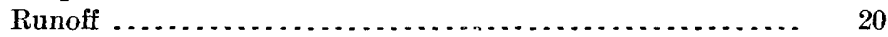

Absorption ......................................... 20

Permeability and storage capacity of rocks ...................... 21

Methods of absorption ............................ 21

Bedding planes ................................. $\quad 22$

Solution caverns................................... $\quad 22$

Faults .............................................. 22

Joints ........................................... 23

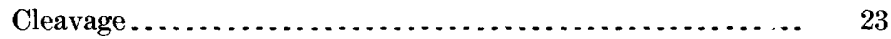

Foliation and schistosity .......................... 23

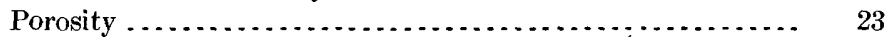

Occurrence and amount of ground water ....................... 24

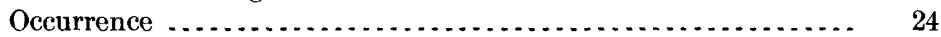

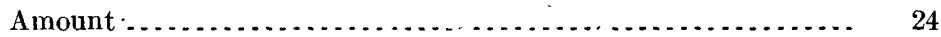

Water-bearing formations......................................... 25

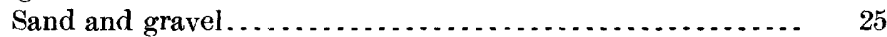

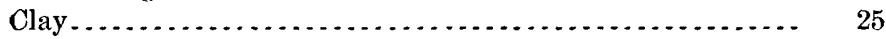

Till.............................................. 26

Sandstone, conglomerate, and quartzite ............... 27

Slate .......................................... $\quad 27$

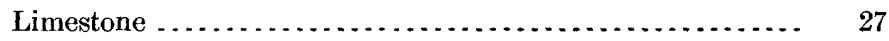

Granite, gneiss, and schist ......................... 28

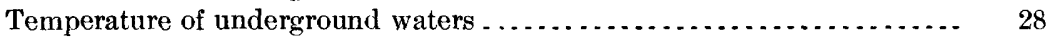

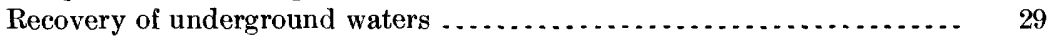

Seepage.............................................. $\quad 29$

Springs .............................................. $\quad 30$

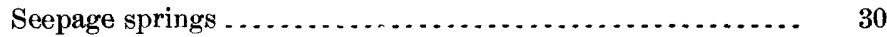

Springs from definite underground channels............. 31

Fissure springs ................................. 31

Geyser springs ..................................... $\quad 32$

Wells........................................................ 33

Dug wells..................................... 33

Driven wells .................................... 33

Drilled and bored wells.......................... 33

Pumps............................................... 33 
Occurrence of underground waters-Continued. Page.

Artesian flows. ................................................. 34

Essentłal conditions ...................................... 34

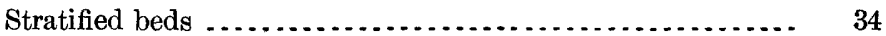

Joints and faults ................................... 34

Direction of movement of water ....................... 35

Underground water conditions in eastern United States ............... 35

Area of glacial drift .................................... $\quad 36$

Weathered rocks.................................... 37

Rock water provinces................................ 38

Coastal Plain..................................... 38

Piedmont Plateau ............................... 39

Appalachian Mountains............................. 39

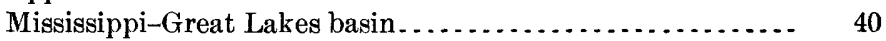

Maine, by W. s. Bayley ..................................... 41

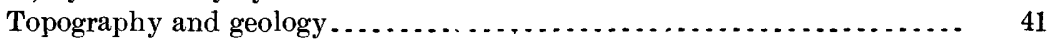

Water supply .............................................. 41

Public supplies.......................................... 43

Rivers.................................................... 44

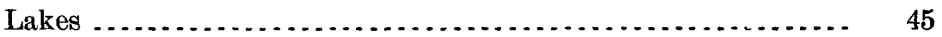

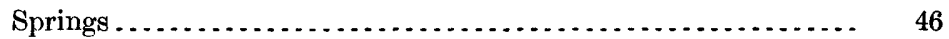

Drilled wells . . . . . . .

Private supplies....................................... 47

Dug, driven, and bored wells......................... 47

Drilled wells ................................................ 48

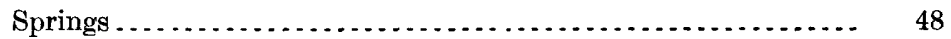

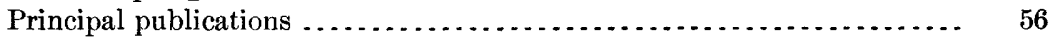

New Hampshire, by M. L. Fuller ............................... 57

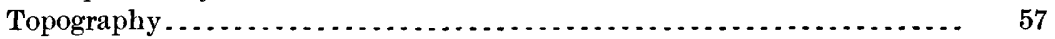

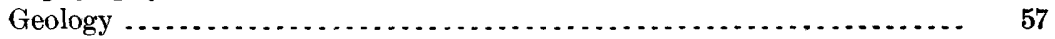

Underground waters............................................. 58

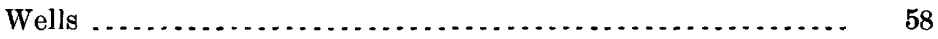

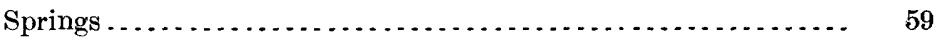

Principal publications ........................................ 59

Vermont, by G. H. Perkins....................................... 60

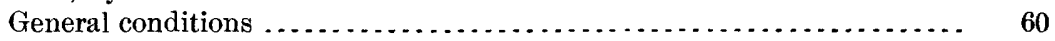

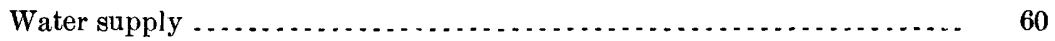

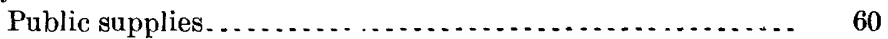

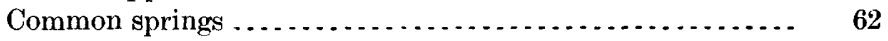

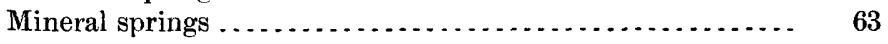

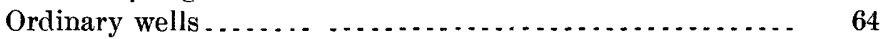

Deep and artesian wells. ........................... 64

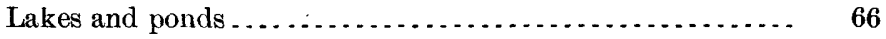

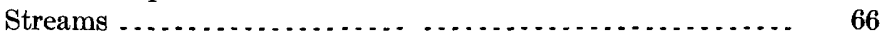

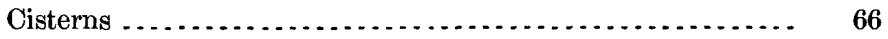

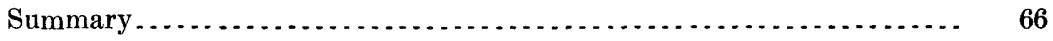

Principal publications ......................................... 67

Massachusetts and Rhode Island, by W. O. Crosby ................. 68

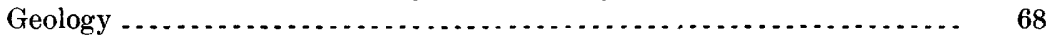

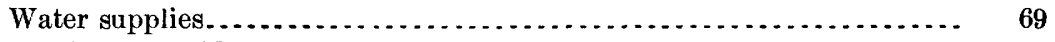

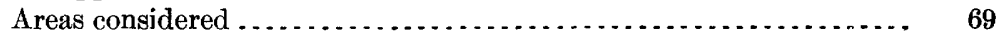

Berkshire Valley ................................... 70

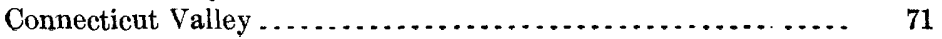


Massachusetts and Rhode Island-Continued.

Water supplies-Continued.

Page.

Areas considered-Continued.

Eastern and western highlands ......................... 71

Nashua Valley ...................................... 72

Coastal lowlands ........................................... 72

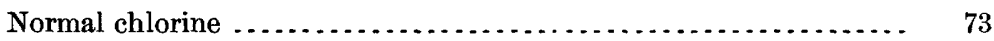

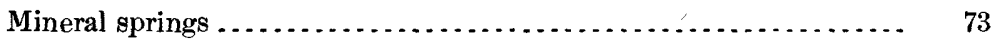

Massachusetts.............................................. 73

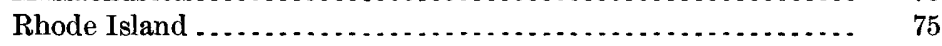

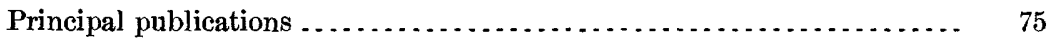

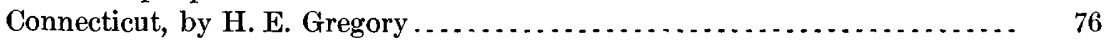

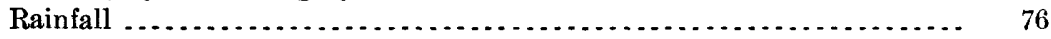

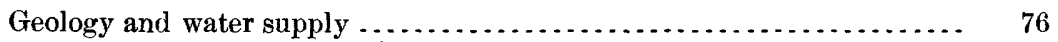

Geologic subdivisions. . . . . . . .

Limestone area . .................................. 76

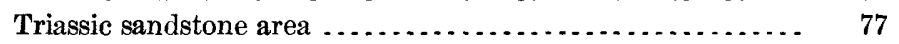

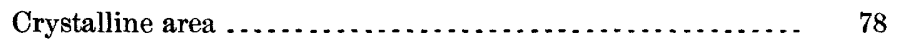

Faults ........................................... 79

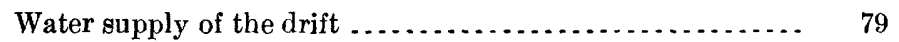

Mineral springs . . . .

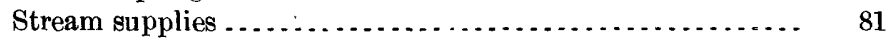

Irrigation. . . . . . . . .

Principal publications ............................................ 81

New York, by F. B. Weeks.................................. 82

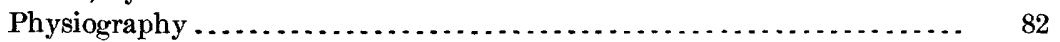

Geology and underground waters.............................. 83

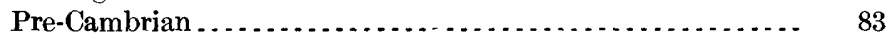

Cambrian.......................................... 83

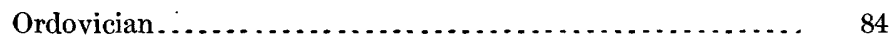

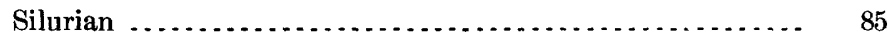

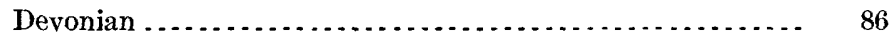

Triassic ......................................... 86

Cretaceous ........................................ 86

Quaternary .............................................. 87

Production of mineral waters................................. 87

Principal publications ......................................... 92

New Jersey, by G. N. Knapp................................. 93

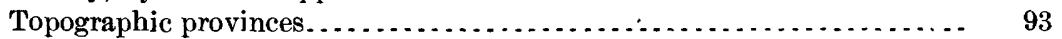

Geology and water supply ..................................... 94

Appalachian province................................. 94

Crystalline highlands province........................ 95

Piedmont province. ....................................... 96

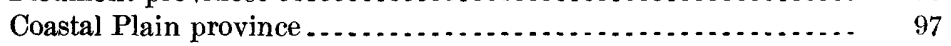

Summary of water resources.......................... 101

Distribution of wells and population ................... 102

Mineral springs.................................. 102

Principal publications ....................................... 103

Pennsylvania, by M. L. Fuller ................................ 104

Topography................................................ 104

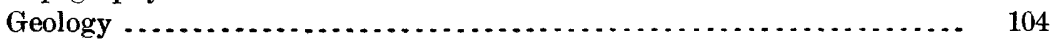

Sources of water supply ................................... 105

Streams and lakes .................................... 105 
Pennsylvania-Continued.

Sources of water supply-Continued.

Page.

Wells.............................................. 106

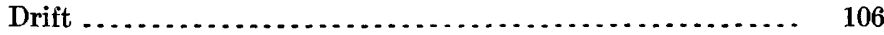

Stream deposits $\ldots \ldots \ldots \ldots \ldots \ldots \ldots \ldots \ldots \ldots \ldots \ldots \ldots . . \ldots \ldots$

Crystalline rocks ................................. 106

Triassic rocks .................................. 107

Cambrian and Silurian rocks ....................... 107

Devonian rocks................................. 107

Carboniferous rocks............................... 108

Coastal Plain deposits.......................... 108

Mineral springs. ........................................ 109

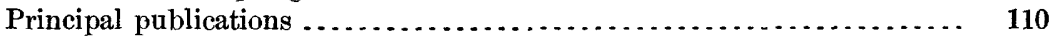

Delaware, by N. H. Darton ................................... 111

Geology .................................................... 111

Water horizons............................................. 111

Water supplies .............................................. 112

Deep wells ......................................... 112

Well prospects ...................................... 113

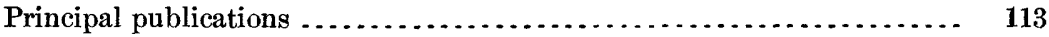

Maryland, by N. H. Darton and M. L. Fuller ...................... 114

Topography and geology .................................... 114

Water supplies ........................................... 115

Springs .................................................... 115

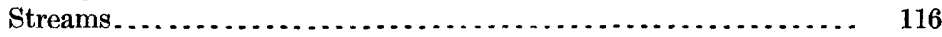

Wells................................................ 116

Allegheny Plateau............................. 116

Appalachain Mountains......................... 116

Piedmont Plateau .............................. 116

Coastal Plain..................................... 117

Water horizons. ............................................. 118

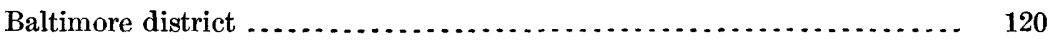

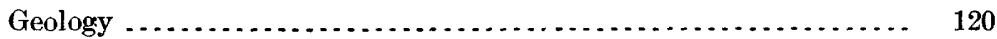

Water horizons and well prospects........................ 121

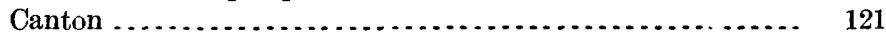

East Baltimore from Canton to the Basin ............... 121

$\begin{array}{ll}\text { Region between the Basin and Harbor and Middle Branch.... } & 121\end{array}$

Region from Brooklyn to Curtis Bay................ 122

Region southeast of Canton to Sparrow Point............ 122

Northeast Baltimore............................. 122

Western part of Baltimore ......................... 123

Principal publications ........................................ 123

District of Columbia, by N. H. Darton and M. L. Fuller................ 124

Geology .............................................. 124

Water horizons and prospects ............................... 124

Waters of the crystalline rocks .................... 124

Waters of the sedimentary rocks................... 125

Mineral springs ................................... 126

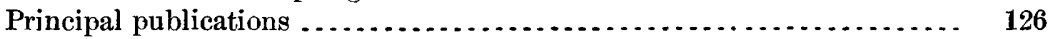

Virginia, by N. H. Darton and M. L. Fuller...................... 127

Physiographic divisions...................................... 127

Geology and water horizons................................. 127

Coastal Plain ............................................... 127

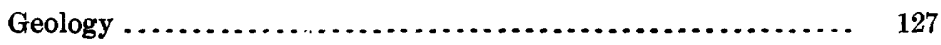


Virginia-Continued.

Geology and water horizons-Continued.

Page.

Coastal Plain-Continued.

Water horizons....................................... 128

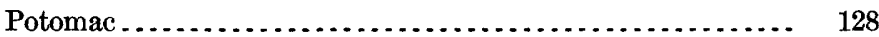

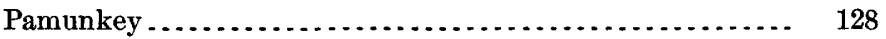

129

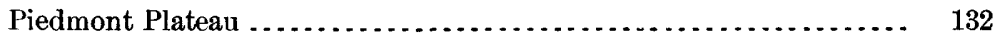

Crystalline rocks .............................. 132

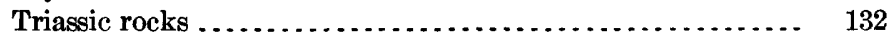

Appalachian Mountain belt . . . . . . . . . . . . . . . . . . . . . . . 132

Cumberland Plateau................................... 133

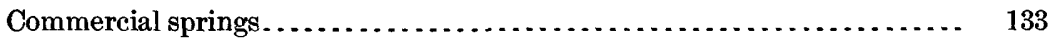

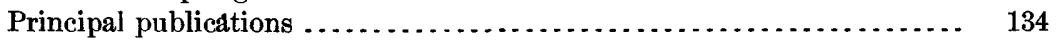

North Carolina, by M. L. Fuller. . . . . . . . . . . . . . . . . . . . . . . . 136

Coastal Plain................................................ 136

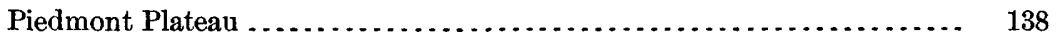

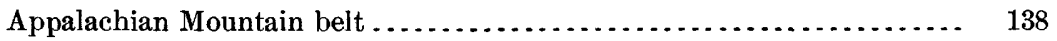

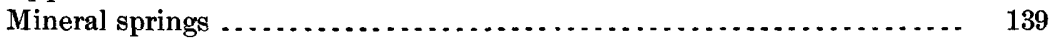

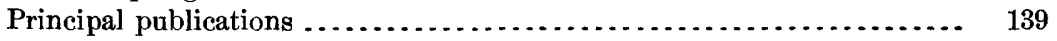

South Carolina, by L. C. Glenn .................................. 140

Subdivisions ........................................... 140

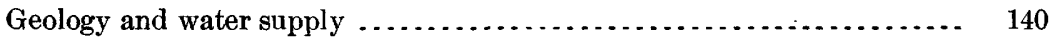

Piedmont Plateau ...................................... 140

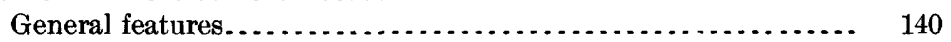

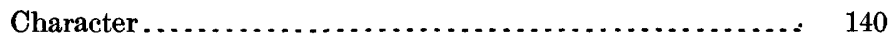

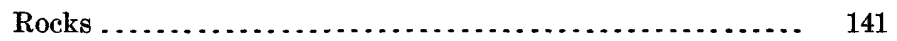

Residual soil mantle................................ 141

Water supplies of Piedmont Plateau ....................... 141

Effect of residual mantle ........................... 141

Springs ......................................... 141

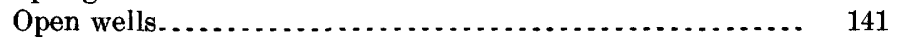

Deep wells..................................... 143

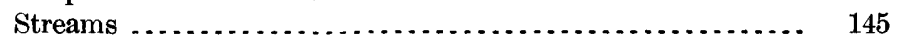

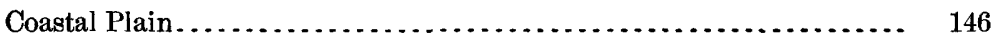

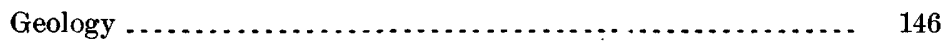

Crystalline floor . ............................. 146

General character of deposits.................... 146

Potomac formation ........................... 146

Marine Cretaceous beds.......................... 147

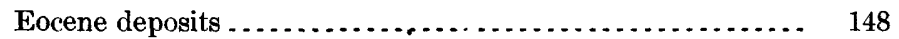

Miocene marl .................................... 148

Lafayette and Columbia sands...................... 148

Wells ............................................ 149

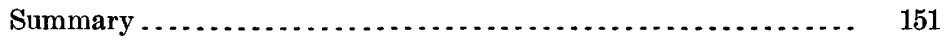

Shallow wells ..................................... 151

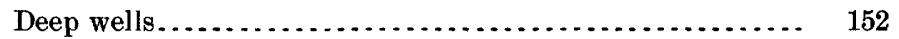

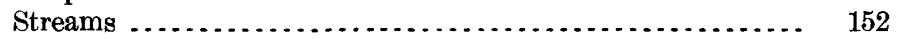

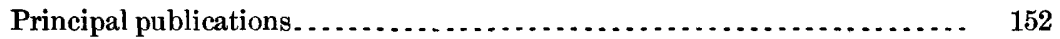

Georgia, by S. W. McCallie .................................... 153

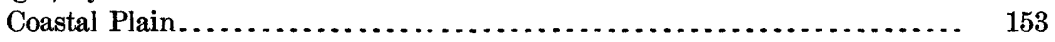

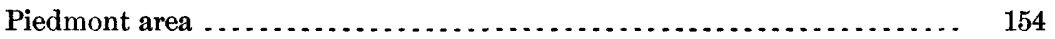

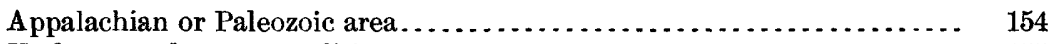

Underground water conditions $\ldots \ldots \ldots \ldots \ldots \ldots \ldots \ldots \ldots \ldots \ldots \ldots \ldots \ldots \ldots \ldots$ 
Georgia-Continued. Page.

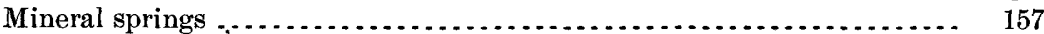

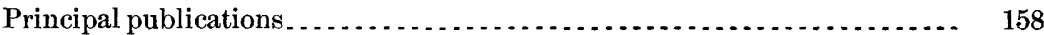

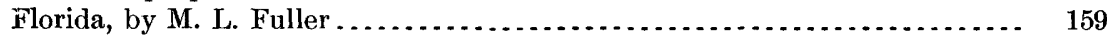

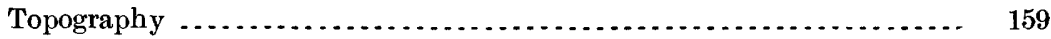

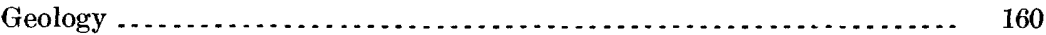

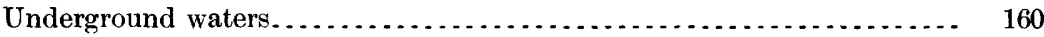

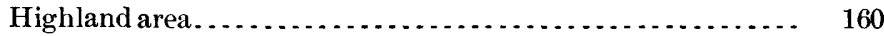

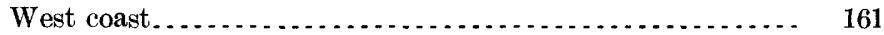

East coast. ... . . . . .

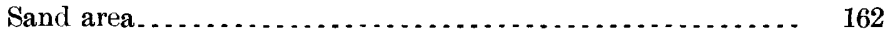

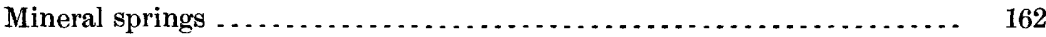

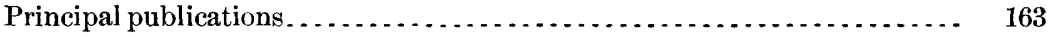

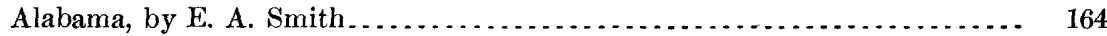

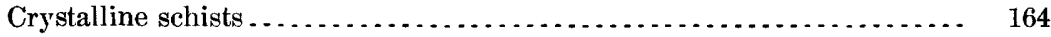

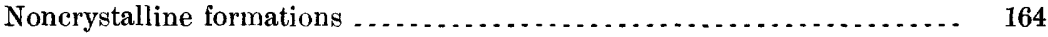

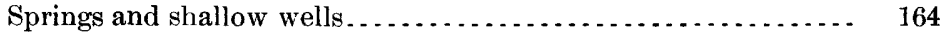

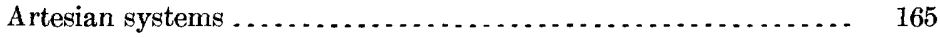

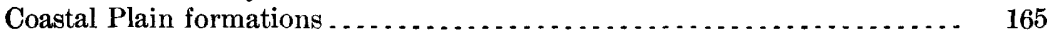

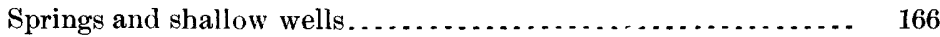

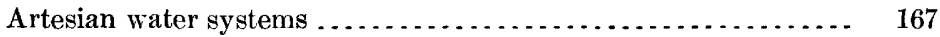

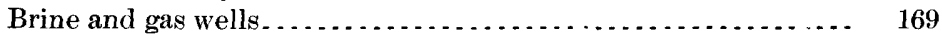

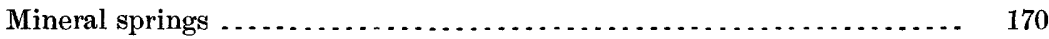

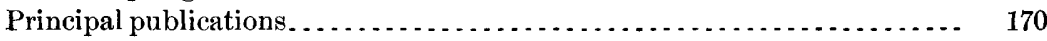

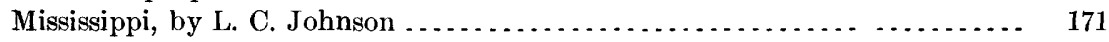

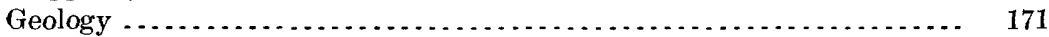

Mississippian rocks. . . . . . . . . . . . . . . . . . . 171

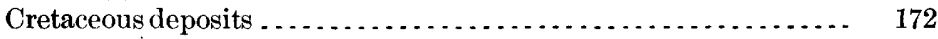

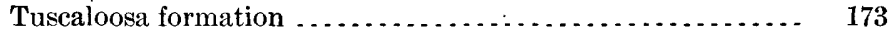

Eutaw beds . . . . . . . . . . . . . . . . . . 173

Selma chalk or Rotten limestone.................. 173

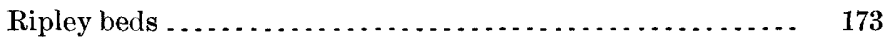

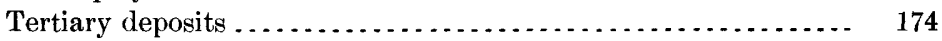

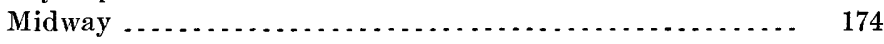

Lignitic group. . . . . . . . . . . . . . . . . . . . . . . . 174

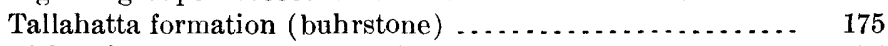

Lisbon formation (calcareous Claiborne) ............. 175

Jackson and Vicksburg formations.................. 176

Grand Gulf group . . . . . . . . . . . . . . . . 176

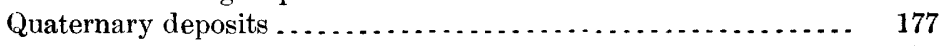

Lafayette sands and gravels ...................... 177

Loess and loam ..................................... 177

Pontchartrain clay and Biloxi sand .................. 177

Alluvium ........................................... 177

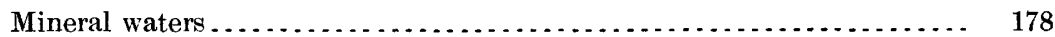

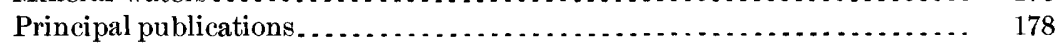

Louisiana and southern Arkansas, by A. C. Veatch . . . . . . . . . . . . . . 179

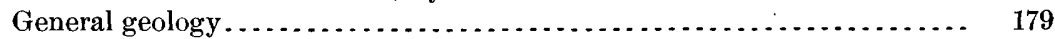

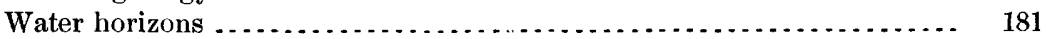

Lower Cretaceous ................................ 181

Bingen sand ............................................ 182

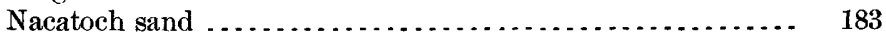

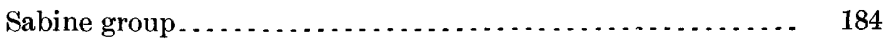

Cockfield beds ................................... 185 
Louisiana and southern Arkansas-Continued.

Page.

Water horizons-Continued.

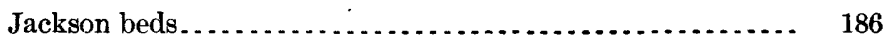

Catahoula beds.................................... $\quad 186$

Mineral springs .........

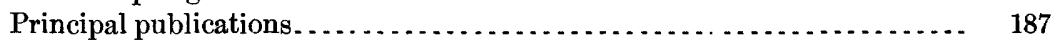

Northern Arkansas, by A. H. Purdue ............................ 188

Description of the region.................................... 188

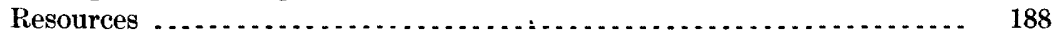

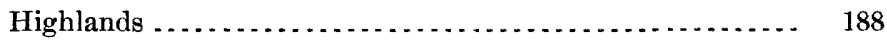

Lowlands ........................................ 189

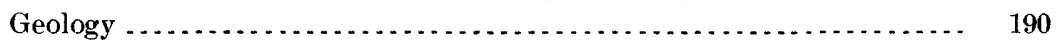

Plateau region $\ldots \ldots \ldots \ldots$

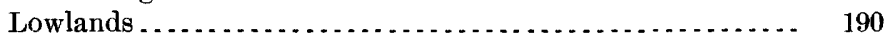

Water resources............................................ 191

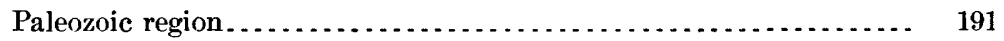

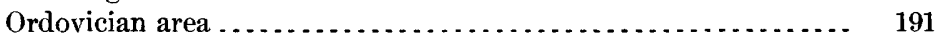

Boone chert area .................................. 192

Boston Mountain area ............................... 193

Batesville sandstone ............................. 193

Archimedes limestone ............................. 193

Pentremital limestone . . . . . . . . . . . . . . . . . . . . . . . . 194

Artesian conditions .................................... 194

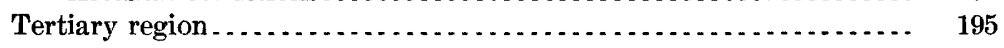

Artesian conditions .................................. 196

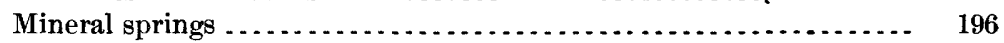

Principal publications......................................... 197

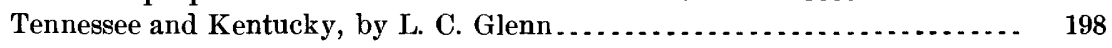

Tennessee ................................................... 198

Topography $\ldots \ldots \ldots \ldots \ldots \ldots$

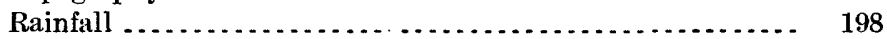

Valley of East Tennessee.................................. 198

Description ....................................... 198

Water resources................................ 198

Cumberland Plateau.................................... 199

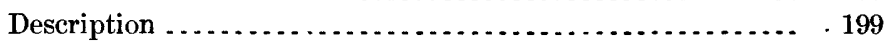

Water resources................................ 200

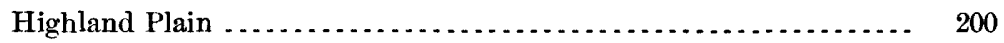

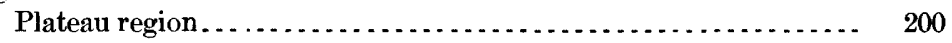

Description ..................................... 200

Water resources.............................. 201

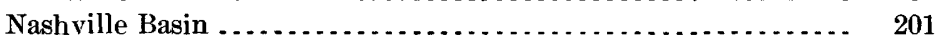

Description . .

Water resources..................................... 201

Western valley of Tennessee River........................ 202

Gulf Coastal Plain ......................................... 202

Description ........................................... 202

Geology and water supply ........................ 203

Mississippi alluvial plain :................................... 205

Commercial springs ....................................... 205

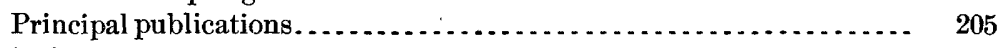

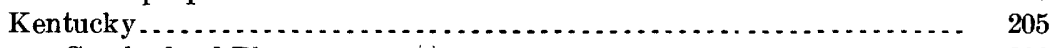

Cumberland Plateau ....................................... 206 
Kentucky-Continued.

Cumberland Plateau-Continued.

Lexington plain

Gulf Coastal Plain

Commercial springs

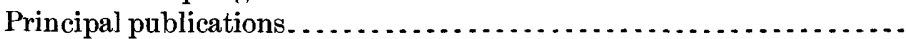

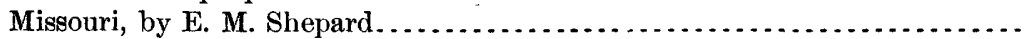

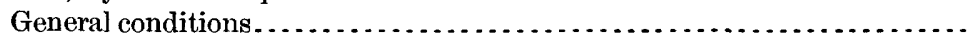

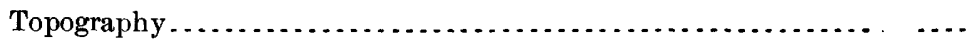

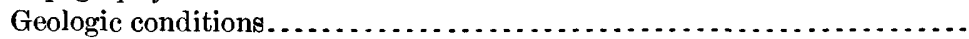

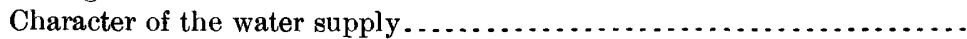

Northwestern plateau district .............................

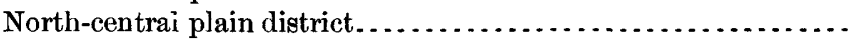

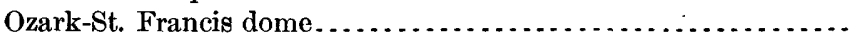

Southeastern lowlands

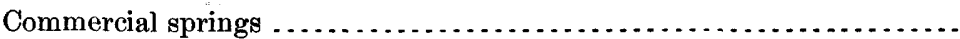

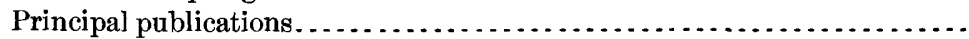

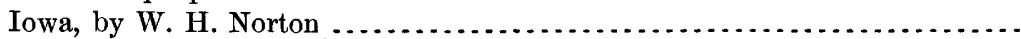

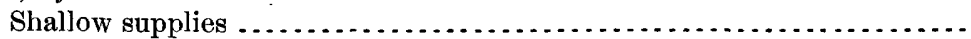

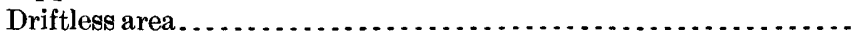

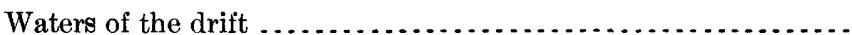

Artesian waters

Cambrian rocks ................................... 223

Ordovician, Silurian, and Devonian rocks............... 223

Carboniferous rocks .................................. 224

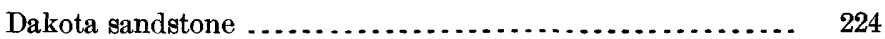

Summary . . . . . . . . . . . . . . . . .

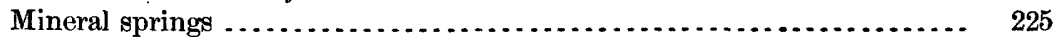

Principal publications............................................ 225

Minnesota, by C. W. Hall ....................................... 226

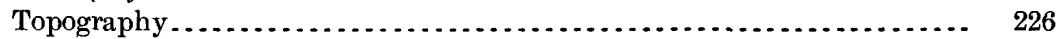

Water resources ............................................ 226

General conditions .................................. 226

Water-bearing strata.................................. 226

Cambrian.......................................... 227

Ordovician...................................... 227

Cretaceous ...................................... 228

Glacial drift...................................... 228

Artesian basins . . . . . . . . . . . .

Southeastern artesian basin ........................ 228

Red River Valley basin ............................ $\quad 230$

Shallow wells .......................................... 231

Springs ................................................... 231

Principal publications......................................... 232

Wisconsin district, by Alfred R. Shultz ......................... 233

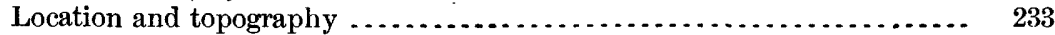

A rea included...................................... 233

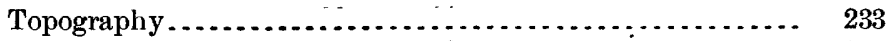

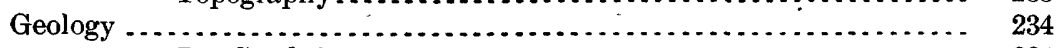

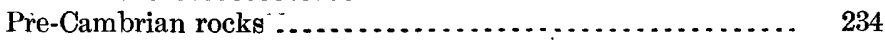

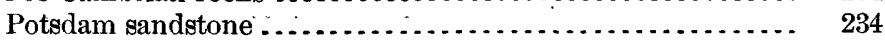

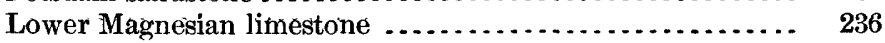

St. Peter sandstone ................................. 236

GaTena-Trenton limestone............................ 236

Cincinnati shale................................. $\quad 236$ 
Wisconsin district-Continued.

Geology-Continued.

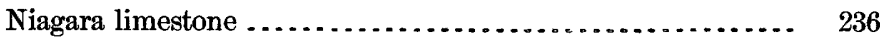

Later rocks ........................................ 237

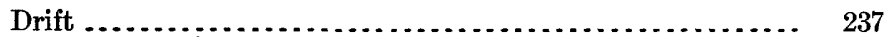

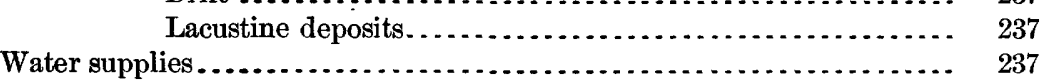

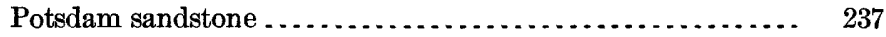

Lower Magnesian limestone......................... 238

St. Peter sandstone ................................. 238

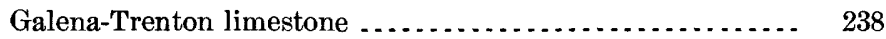

Niagara limestone .................................. $\quad 239$

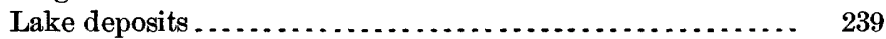

Springs ............................................... $\quad \mathbf{2 3 9}$

Mineral waters...................................... 240

Principal publications...................................... 241

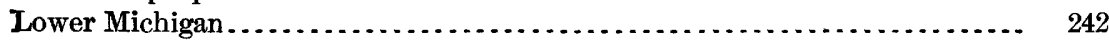

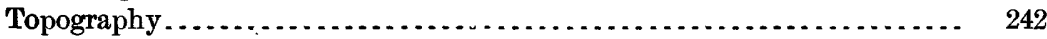

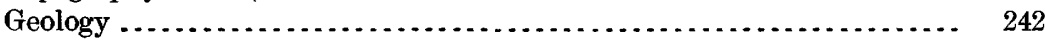

Underground water supplies ................................ 242

Supplies of the drift . ................................ 242

Eastern shore district............................. 242

Saginaw Valley district $\ldots . \ldots \ldots \ldots \ldots \ldots \ldots \ldots \ldots \ldots \ldots . .244$

Northeastern shore district.......................... 244

Western shore district ................................. 244

North-central district ............................... 245

Saginaw moraine district............................ 245

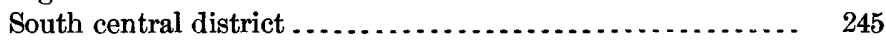

Rock waters ........................................ 245

Trenton limestone.................................. 245

Hudson and Utica shales............................. 245

Niagara and Clinton limestones .................... $\quad 245$

Monroe and Salina beds ........................... 245

Dundee limestone ................................... $\quad 245$

Traverse series ..................................... 245

Antrim shales.................................... 245

Berea shale and grit.............................. 246

Coldwater shales .................................... 246

Lower Marshall sandstone ........................... 246

Napoleon or Upper Marshall sandstone .................. $\quad 246$

Michigan series................................... 246

Parma sandstone ................................... 246

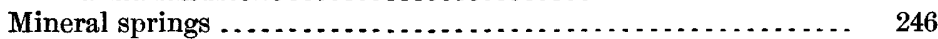

Principal publications......................................... 247

Illinois, by Frank Leverett ........................................ 248

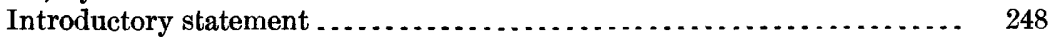

Geologic column ......................................... 248

Principal water-bearing formations . . . . . . . .................... 250

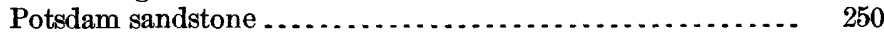

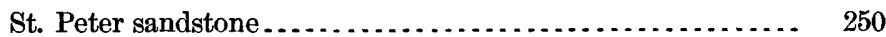

Galena limestone........................................ 250

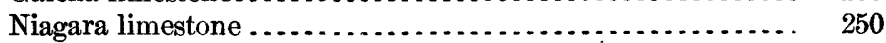

Devonian limestones................................... 251

St. Louis limestones . . . . . . . . . . . . . . . . . . . . . . . . . 251

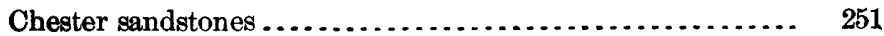


Illinois-Continued.

Principal water-bearing formations-Continued.

"Conglomerate" sandstone ........................... 251

Coal Measures..................................... 251

Tertiary deposits ................................... 251

Glacial deposits ................................... . 251

Localities favorable for artesian wells.......................... 252

Waters in relation to habitation ................................ 254

Mineral springs ............................................ 256

Principal publications......................................... 256

Indiana, by Frank Leverett ...................................... 258

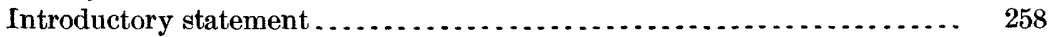

Geologic column ............................................... 258

Principal water-bearing formations ............................ 259

St. Peter sandstone .............................. $\quad 259$

Trenton limestone.............................. $\quad 259$

Hudson River beds................................ 260

Clinton and Medina beds ........................... 260

Niagara limestone ................................. $\quad 260$

Waterlime and Lower Helderberg limestones............ $\quad 260$

Devonian shales................................. 260

Waverly shale ................................. $\quad 260$

Knobstone formation ................................. 260

St. Louis limestone beds ............................. 261

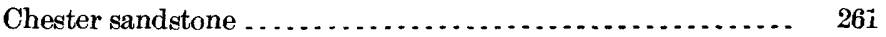

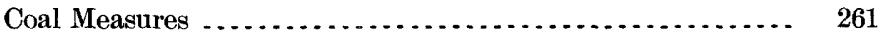

Tertiary deposits ................................ 261

Drift ............................................... 261

Localities favorable for artesian wells .......................... 263

Mineral waters.............................................. 263

Principal publications ........................................ 264

Ohio, by Frank Leverett...................................... 265

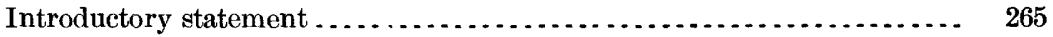

Geologic column ......................................... 265

Characteristics of waters of different depths ....................... 266

Relative values of different rock formations as water-bearers.......... 266

Trenton limestone............................ $\quad 267$

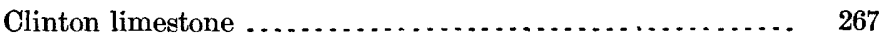

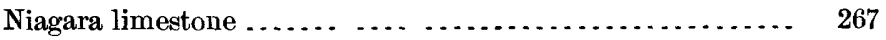

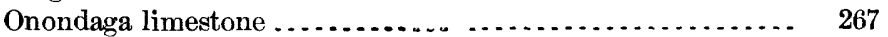

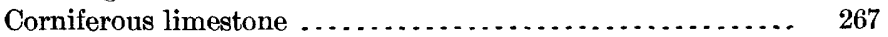

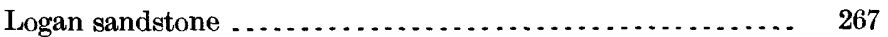

Berea grit.................................... 267

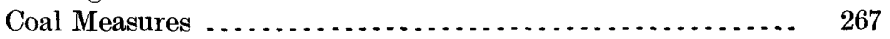

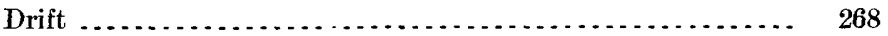

Localities favorable for artesian wells ........................ 268

Mineral springs ........................................... 269

Principal publications .......................................... 270

West Virginia, by M. L. Fuller ................................ 271

Appalachian Mountain belt .................................. 271

Cumberland Plateau....................................... 272

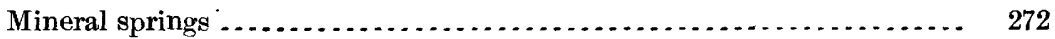

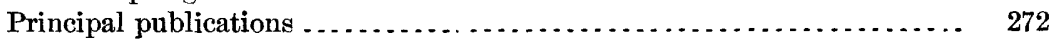

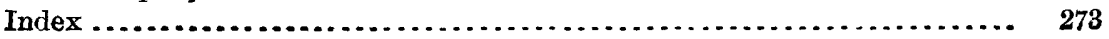




\section{L L U S T R A T I 0 N S.}

Plate I. $A$, A sink-hole connection with underground drainage system; $B$,

Underground channel ...................................

Page.

II. $A$, Outcrop cut by joint openings; $B$, Cleavage in slate............

III. $A$ and $B$, Sandstones viewed under the microscope..............

IV. $A$, Spring formed at outcrop of impervious floor; $B$, Artesian well

V. Map showing geologic areas and spring localities of New York .....

VI. Sections across southern New Jersey . . . . . . . . . . . . . . . . . . . . . .

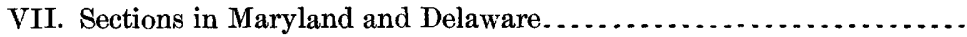

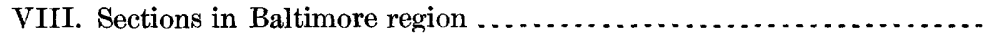

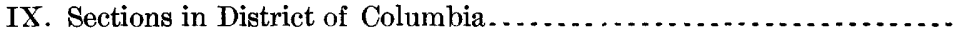

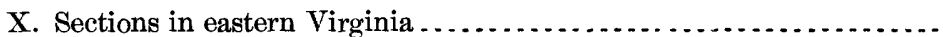

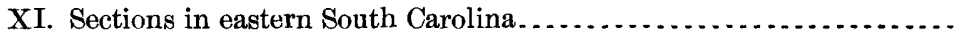

XII. Map showing artesian systems of Alabama ....................

XIII. Geologic map of northern Arkansas ..........................

XIV. Map showing artesian localities in Iowa.......................

XV. Geologic sketch map of Illinois..............................

XVI. Map showing thickness of drift in Illinois....................

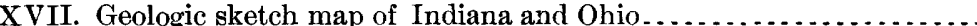

XVIII. Map showing thickness of drift in Indiana and Ohio............. 262

Fic. 1. Rainfall map of eastern United States......................... 19

2. Absorptive conditions of outcrops .......................... 21

3. Relation of areas of outcrop to dip ........................ 22

4. Common types of faults ................................. 22

5. Relative size and storage capacity of dug and drilled wells........ 26

6. Differences in conditions of adjacent wells in limestone ........... 27

7. Well in jointed rocks..................................... 28

8. Lines of underflow into channel ............................ 30

9. Springs along faults or joints near South Britain, Conn ............ 32

10. Section showing principal requisites of artesian wells .............. 34

11. Section illustrating thinning out of porous water-bearing bed ........ 35

12. Section showing transition from a porous to a nonporous water bed... 35

13. Upward circulation of water along joint........................ 35

14. Geologic and water-supply districts in eastern United States......... 36

15. Location of flowing or nearly flowing wells of Maine............... 49

16. Water-bearing drift deposits of Vermont..................... 65

17. Areas of limestone, sandstone, and crystalline rock water supplies of

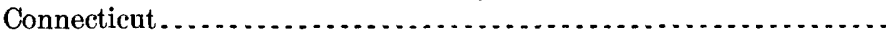

18. Subdivisions of New Jersey governing the occurrence of underground

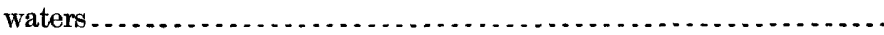

19. Geologic subdivisions of Pennsylvania.......................

20. Cross section of the Coastal Plain region of North Carolina........... 
FIG. 21. Areas of flowing wells in Georgia ............... Page.

22. Principal artesian areas of Florida $\ldots \ldots \ldots \ldots \ldots \ldots \ldots \ldots \ldots \ldots \ldots . \ldots 1$

23. Geologic sketch map of Mississippi ........................ 172

24. Deep-water prospects in Louisiana and southern Arkansas........... 181

25. Artesian areas in Louisiana and southern Arkansas . . . . . . . . . . .... 182

26. Section from Locksburg, Ark., to Cameron, La .................. 183

27. Section from Eldorado, Ark., to Abbeville, La .................. 184

28. Relief map of Arkansas................................... 189

29. North-south section from Missouri line to Arkansas River ........... 190

30. Generalized east-west section across northern Arkansas . .......... 193

31. Geologic sketch map of Missouri............................ 210

32. Ideal cross section through Missouri ........................ 211

33. Sketch map of Missouri showing water resources................ 212

34. General geologic section of Iowa.......................... 221

35. Artesian basins of Minnesota ............................. 229

36. Geologic section from Baraboo, Wis., to Des Moines, Iowa ......... 233

37. Wisconsin outcrop of Potsdam and St. Peter sandstones............ 235

38. Geologic sketch map of lower Michigan ...................... 243

39. Section across lower Michigan............................. 244

40. Section from Wisconsin River to Cap au Grès. ................... 253 


\title{
LETTER OF TRANSMITTAL.
}

\author{
DePARTMENT OF THE' INTERIOR, \\ United States Geological Survey, \\ Hydrographic Branch, \\ Washington, D. C., May 11, 1904.
}

SIR: I have the honor to transmit herewith a manuscript entitled "Underground Waters in Eastern United States," which I would recommend to be published in the series of Water Supply and Irrigation Papers.

The aim of the paper is to present a brief summary of the underground water conditions in the States east of the Mississippi and in those States bordering that river on the west. It is prepared to meet the demand of drillers and others for general information relating to the broader features of the occurrence of underground waters in the various States or districts.

The report includes papers by twenty geologists and embraces discussions of the conditions in each State and of the general occurrence of underground waters as a whole.

Very respectfully,

F. H. NEwELL, Chief Engineer.

Hon. Chardes D. Walcott,

Director United States Geological Survey. 


\title{
UNDERGROUND WATERS OF EASTERN UNITED STATES.
}

\author{
M. L. Fuller,
}

Geologist in charge.

\section{IN TRODUCTION.}

\author{
By M. L. Fuller.
}

The present paper is a brief summary of the urderground water conditions in eastern United States, prepared to meet the demands of drillers and others for infornation relating to the general water resources of the various States or of specified regions.

The detail with which the several regions or subjects are discussed depends mainly on their relative importance, although because of the greater amount of work done in certain localities, or on certain problems, it is possible to make more complete and definite statements in regard to the underground water supplies in some regions than in others. The included reports have been prepared by a number of geologists, each, in general, having charge of the investigations in a particular State or group of States. Because of the number of contributors there is necessarily considerable variation in the manner of treatment of the subject, but in most cases the same general plan has been followed.

In preparing the paper simplicity of treatment has been kept in mind, and elaborate geologic discussions have been omitted. Wherever possible maps have been given in preference to long and possibly obscure discussions. In some instances, however, it has been necessary to describe the various water-bearing formations under their geologic names. Where this has been necessary the aim has been to employ those terms which are oldest and best known to the people of the States to which the discussion relates.

For the purpose of presenting in a simple manner a few of the more important features relating to the nature and occurrence of subterranean waters and of making more intelligible the descriptions of the conditions in the various States, there is given a short paper on the general occurrence of underground waters.

IRR $114-05-2$ 


\title{
OCCURRENCE OF UNDERGROUND WATERS.
}

\author{
By M. L. Fuller.
}

\section{SOURCES OF GROUND WATER.}

In general those who have written on underground waters have stated that rainfall is the only source of underground waters. In reality, however, while rainfall probably contributes at least 99 per cent to the total subterranean water, there are several other possible sources of such water.

It is a well-known fact that in coral and other islands of porous material, such as sand and gravel, especially where the rainfall is light, the sea water penetrates through the pores of the rock for a considerable distance inland. Where the rainfall is heavy the salt water may be displaced to some depth by fresh water, but the downward penetration of the fresh water must be necessarily limited. In other instances sea water is known to penetrate along solution passages or caverns into the interior of limestones, and at Cephalonià, in Greece, a stream of salt water leaves the sea and, passing inland, finally disappears into porous limestones.

By far the larger portion of the sedimentary deposits, including sandstones, shales, limestones, etc., were originally laid down along the borders or beneath the surface of the ocean and were, of course, originally saturated with salt water. It is probable that this water was often retained in the materials when they became consolidated into rocks, and is represented by the salt water now found at great depths in many of the wells drilled for oil and gas, in which it is not uncommon to encounter, after passing through many hundred feet of entirely dry rock, porous beds filled with salt water, possibly accompanied by gas and oil. It is claimed by others, however, that the salt waters are not originally included portions of the sea, but are surface waters which have become charged with mineral matter which they have dissolved in the course of their passage through the rock.

Practically all volcanic rocks contain water when they are erupted at the surface and all eruptions are accompanied by discharges of large amounts of steam. The occurrence of this water has been accounted for in several ways. It may have been originally included in the rocks which were melted to form the lava, or it may represent water which 
has penetrated downward through fissures and come in contact with the molten lava on its way to the surface.

\section{AMOUNT OF RAINFALL.}

The rainfall in the eastern United States is abundant, and although only a portion of it is absorbed by the earth and becomes a part of the subterranean stores, the amount is sufficient to furnish ample under-

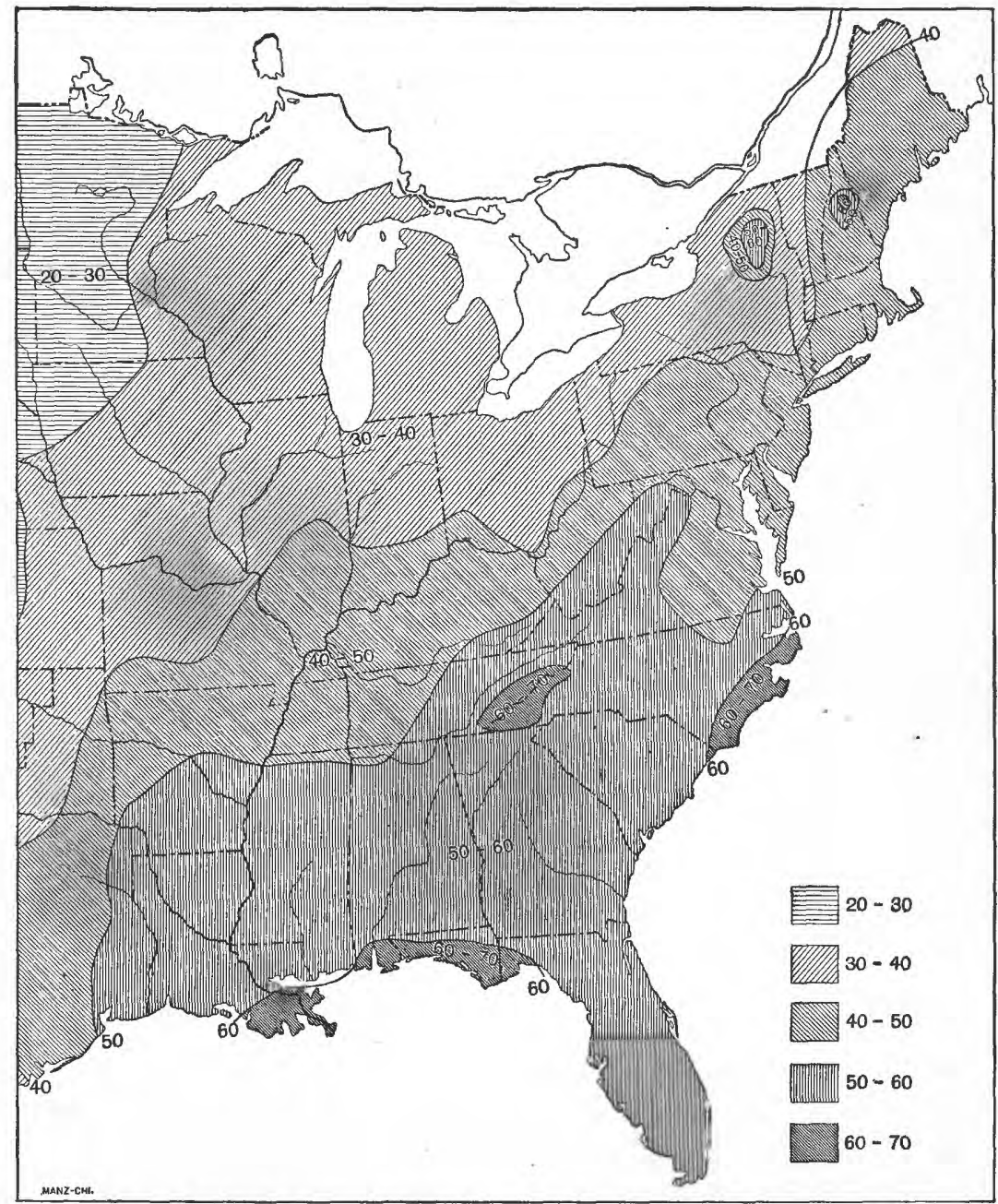

FIG. 1.-Rainfall map of eastern United States. Figures represent inches of annual rainfall.

ground supplies for a large proportion of the inhabitants. The average rainfall varies from 20 to nearly 70 inches, the lowest being in the extreme northwestern portion of Minnesota. Rain to a depth of over 60 inches a year falls on the Mississippi delta below New Orleans and along the Gulf coast from near Mobile, Ala., to Tallahassee, Fla. 
Similar amounts fall in the higher mountains of western North Carolina and eastern Tennessee, along the coast of North Carolina, and in the Adirondack and.White mountains. In the Gulf and South Atlantic States the rainfall is between 50 and 60 inches; in the New England, Central Atlantic, and Ohio River States, between 40 and 50 inches; in the Upper Mississippi and Great Lakes States, from 30 to 40 inches, while in northwestern Iowa and most of Minnesota the rainfall is only from 20 to 30 inches.

\section{DISPOSAL OF RAINFALL.}

The rainfall is removed from the surface principally in three ways: (1) By evaporation; (2) by run-off through the streams, and (3) by absorption into rocks and unconsolidated deposits.

Evaporation.-Evaporation, although far less conspicuous than the other methods of removal of the water, is, nevertheless, one of the most important. The amount evaporated depends on the temperature and the relative dryness of the air, and commonly amounts to one-half or more of the total water falling as rain. Locally, evaporation is dependent to a considerable extent on the density of the vegetation, but when broad areas are considered the amount of vegetation has a less conspicuous effect on the total evaporation.

Run-off.-The amount of run-off is dependent partly on evaporation and partly on the nature of the materials on which the rain falls. The proportion of run-off or discharge to the total rainfall is indicated for the Mississippi and its tributaries in the following table: ${ }^{a}$

\section{Proportion of run-off to rainfall in Mississippi basin.}

Ohio

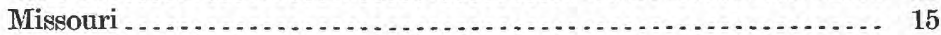

Upper Miississippi ...................................... 24

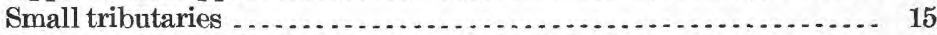

Arkansas and White........................................ 15

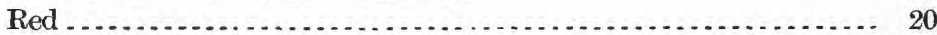

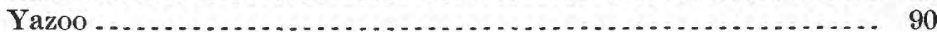

St. Francis............................................ 90

Entire Mississippi system ................................ 25

The run-off of streams in New England is considerably greater. With a rainfall which averages from 40 to 50 inches the run-off of a number of streams is as follows:

Proportion of rainfall to run-off in New England.

Inches.

Kennebec ......................................... 22.4

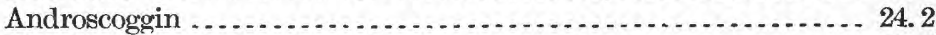

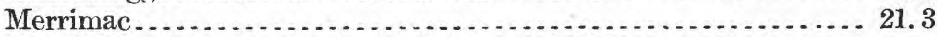

Absorption.- The rainfall that is not removed by evaporation or by the surface streams is absorbed by the soil or rocks with which it comes into contact, either directly or after being gathered into streams.

$a$ Humphreys and Abbot, Phys. and Hydrol. of Mississippi River, Washington, 1861, p. 136. 


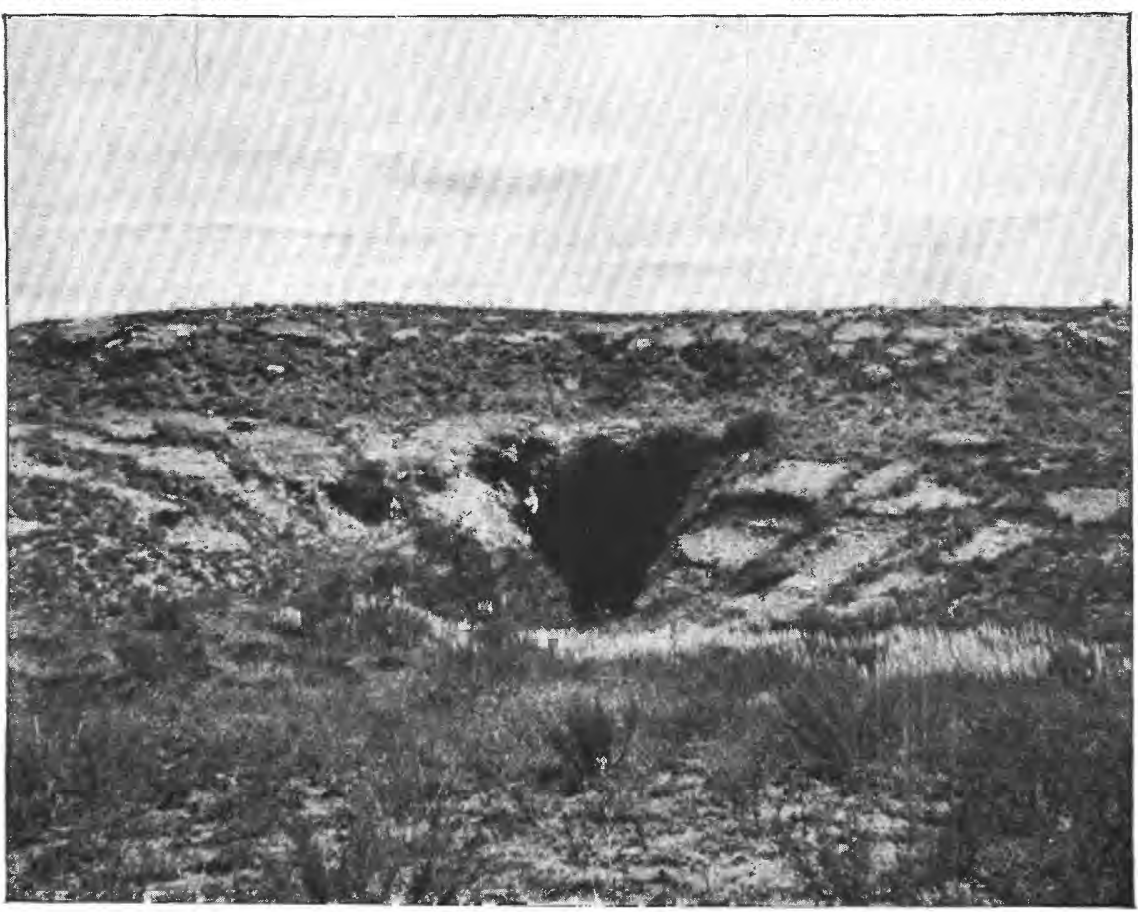

A. SINK-HOLE CONNECTION. WITH UNDERGROUND DRAINAGE SYSTEM.

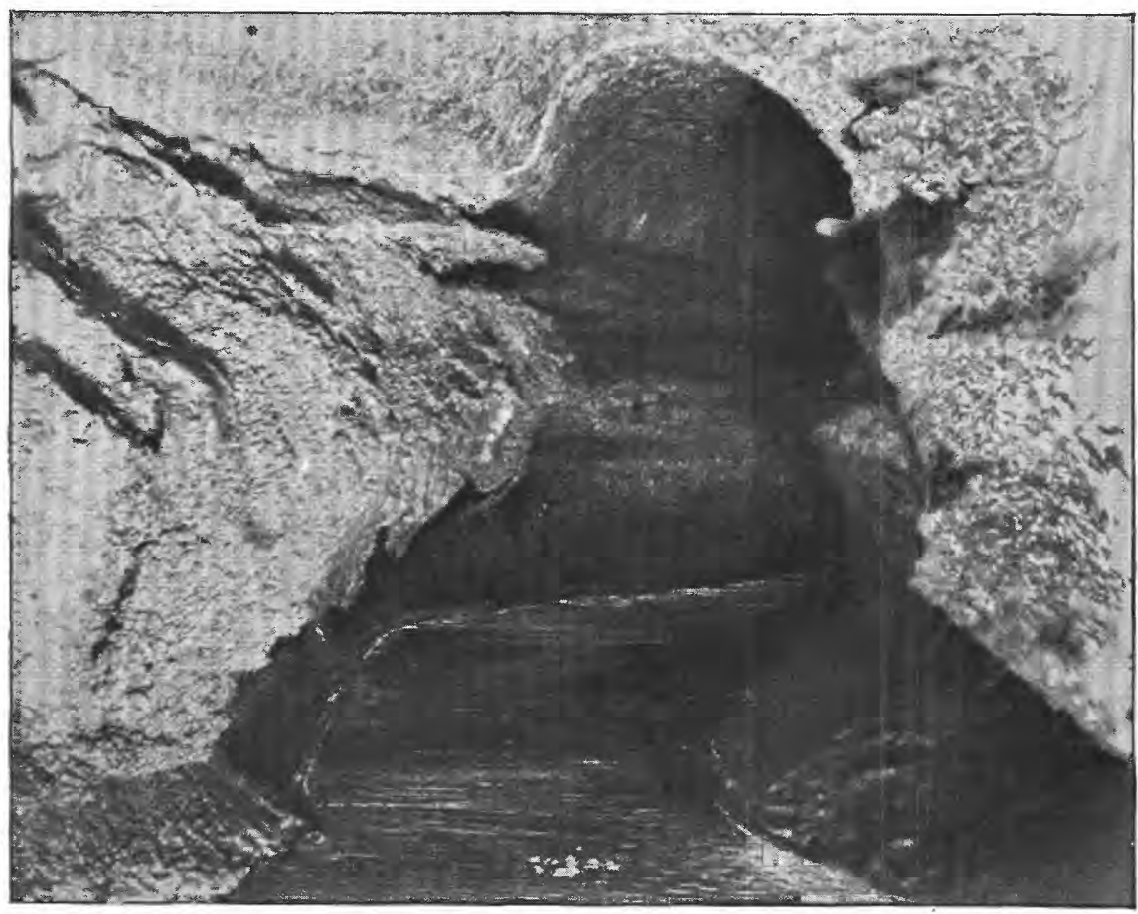


Absorption takes place both directly and indirectly. In the case of direct absorption the rain falls upon the surface of the rock and the water is absorbed either by its pores or by the fissures or cavities which it may contain. In indirect absorption the water is first directly absorbed into loose unconsolidated deposits overlying the solid rocks, or is gathered into streams flowing over their surfaces. In those cases where the rocks are directly exposed to the rainfall the water which is not immediately absorbed runs off and either enters loose materials or is gathered into the streams as indicated. The unconsolidated materials soon become saturated to a certain level, and the rocks upon which they lie are in this way kept constantly in contact with the water, which is continually absorbed.

In the case of the water entering the sands and gravels the direction of the movement is generally toward the river rather than away from it, but in arid regions, where the rainfall is slight, waters are often absorbed by the gravels from the streams which have come from regions of greater rainfall. The relative amount of water indirectly absorbed by the rocks is far greater than that directly received through rainfall.

\section{PERMEABILITY AND STORAGE CAPACITY OF ROCKS.}

Methods of absorption.-The amount of water which enters the rocks or other materials by direct absorption varies greatly with the nature of the materials. The amount absorbed by the porous beds of

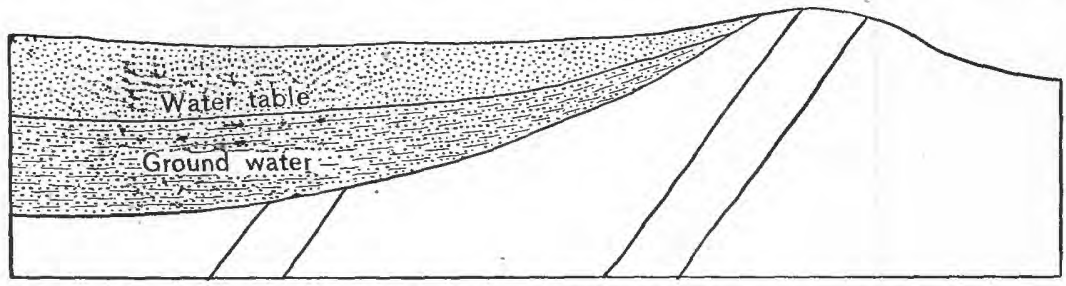

Fra. 2.-Absorptive conditions of outcrop.

sands and gravels that occur along stream valleys and along lake shores and the coast is very large. In some regions, as in portions of Cape Cod and Long Island, there are practically no surface streams, the water being absorbed by the soil as soon as it falls and carried to the sea by underground drainage.

Next to unconsolidated deposits, the rocks which present the conditions most favorable for direct absorption are the sandstones and certain of the porous limestones. In the case of the granites, slates, and other massive rocks the direct absorption is very slight.

Besides the character of the material, the amount of absorption depends very largely upon the inclination of the porous beds, the amount being much greater in the gently inclined beds than in those 
having steep dips. Thus in fig. 3 the two beds represented as outcropping on a level surface present widely different absorptive conditions owing to the difference in area of their absorptive surfaces, the exposed surface of the gently sloping bed $\left(a^{\prime}-b^{\prime}\right)$ being several times greater than that of the highly inclined bed $(a-b)$.
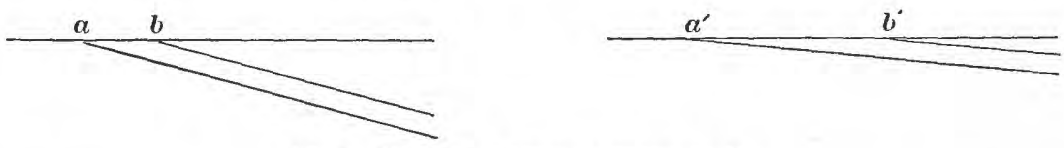

FIG. 3.- Relation of areas of outcrop to dip.

Bedding planes.-Bedding planes are the surfaces separating beds of stratified rock. Where the character of the rock changes, as it frequently does along these bedding planes, the conditions are generally very much more favorable for the passage of water than elsewhere in the rock. The same is true in igneous rocks where two types of rock come together.

Solution caverns.- In a few instances waters enter the ground as definite streams through caverns or other passages formed by the solution of limestone and other similar rock. One of the most commom methods by which water enters the limestones is by means of the depressions known as sink holes. These sinks are due to the caving in of underground caverns which have previously been formed by underground streams. A connection is frequently maintained through these sinks between the surface and the underground channels, and the waters falling on the surface flow into them and pass downward to join the underground supplies. Pl. I, $A$, shows such a sink, while Pl. I, $B$, shows an underground channel in soluble rock.

Faults.-A fault is a plane or fracture which cuts the rocks and along which movement has taken place, resulting in the displacement
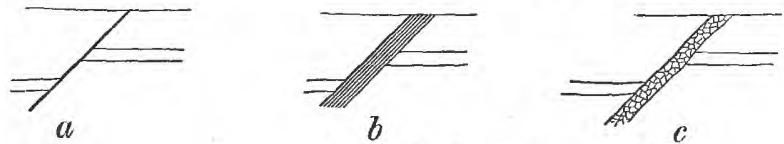

FIG. 4,-Common types of faults.

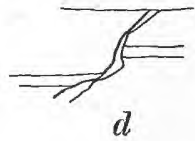

with relation to one another of the rocks on the opposite sides. Sometimes the fault consists of a single plane, with solid walls on either side, as indicated in fig. $4, \alpha$, but in many cases there are really a number of parallel planes, very close together, along which slipping has taken place. In such instances the rock on either side has the sheety appearance indicated in the cross section, fig. $4, b$. In other cases the rocks on either side of the fault plane are completely crushed and the fragments more or less disturbed with relation to one another. In still other cases the fractures are irregular, and the movement of the rocks has been such that projecting points come opposite one another, leaving intervening cavities, as shown in fig. $4, c$. 


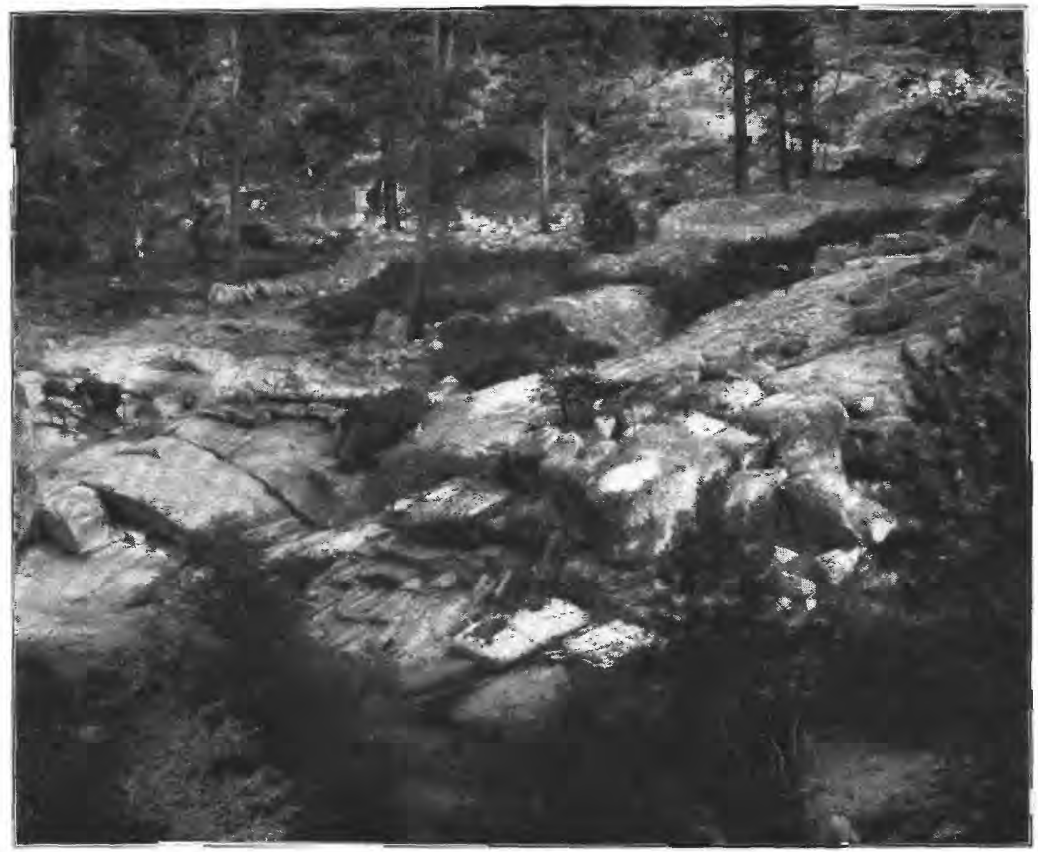

A. OUTCROP CUT BY JOINT OPENINGS.

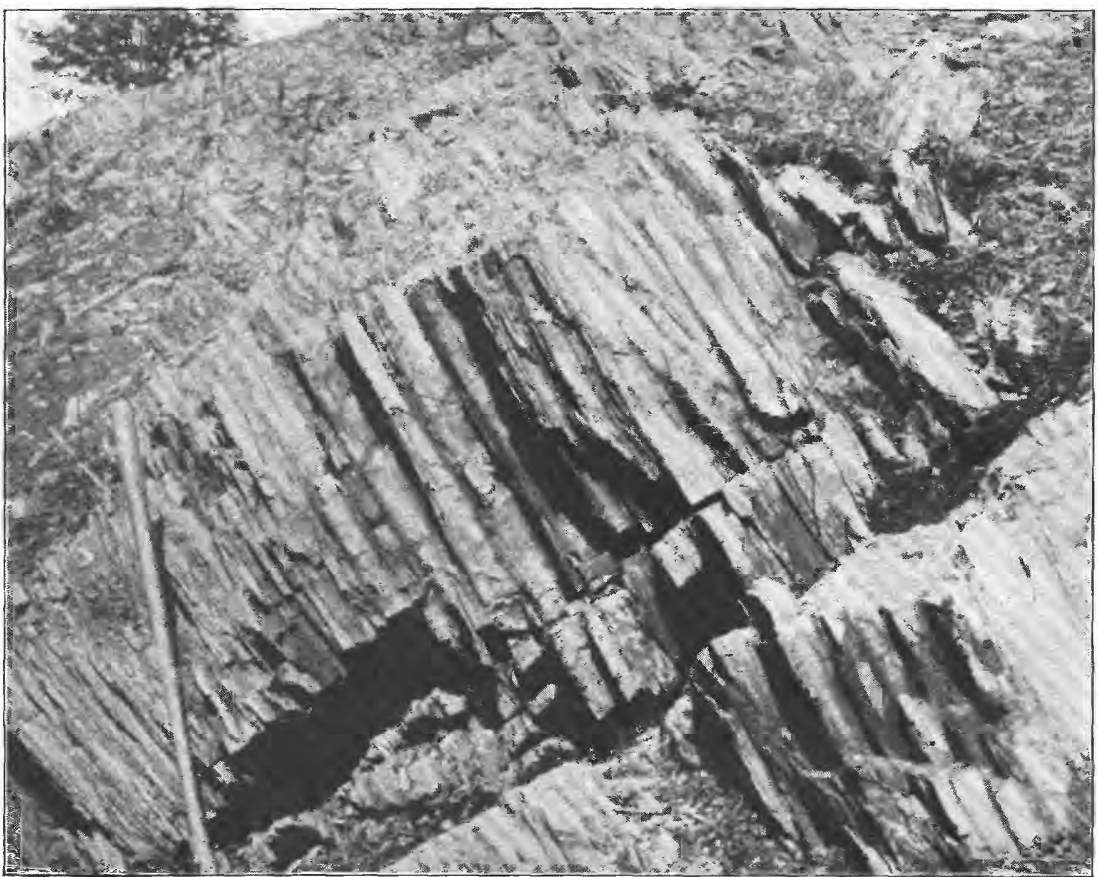

B. cleavage in slate. 
The conditions for the passage of water are least favorable in the case of a single definite fault plane. In the sheeted type of faulting the conditions are somewhat more favorable, as there are more surfaces along which the water can penetrate. Along the crushed zones the open spaces are frequently very considerable and permit the passage of large amounts of water. In the case of an irregular fault plane, as in fig. $4, d$, the conditions are less constant, but in general such a fault will permit of the passage of considerable amounts of water.

Joints.- Joints are smooth fracture planes cutting the rock in various directions. They differ from the faults in that there has been practically no motion of the rocks bordering the plane. They therefore correspond most nearly to the single fault plane described above, and likewise present relatively unfavorable conditions for the passage of large amounts of water. At the same time water in moderate amounts very frequently passes along such planes, especially along the line of intersection of two or more planes. PI. II, $A$, illustrates an outcrop of a rock ledge cut by joints in two directions and presents conditions favorable to the absorption and downward passage of water.

Cleavage.-Cleavage is the name applied to the minor planes cutting the rock. Unlike the joints they usually run in only one direction, and are frequently not actual fractures, but are simply lines along which the rock would tend to split under favorable conditions. Cleavage is best devoloped in fine-grained compact rocks of which the wellknown roofing slate is the best example. Pl. II, $B$, shows a number of these cleavage planes in a ledge of this material. Cleavage does not afford as ready a passage for the water as the other features described.

Foliation and schistosity.-Foliation and schistosity are features due to the occurrence of the minerals of the rock in thin plate-like crystals parallel to one another. The arrangement is such that in many instances water passes with some readiness into the rock along the planes formed by layers or laminæ of these crystals.

Porosity.-Porosity is the term given to designate the amount of pores or open spaces between the particles of which the rock is made up. In a general way porosity is determined by the amount of water which the rock is capable of absorbing. The amount varies greatly, being least in the compact igneous rocks and greatest in sandstones and loose sand. In the following table are given the amounts of water which a cubic foot of sand and some common rocks will absorb:

\begin{tabular}{|c|c|c|c|}
\hline Material. & $\begin{array}{l}\text { Water ab- } \\
\text { sorbed per } \\
\text { cubje foot. }\end{array}$ & Material. & $\begin{array}{l}\text { Water ab- } \\
\text { sorbed per } \\
\text { cubic foot. }\end{array}$ \\
\hline Sand ......... & $\begin{array}{l}\text { Quarts. } \\
10\end{array}$ & Dolomite & $\begin{array}{l}\text { Quarts. } \\
1-10\end{array}$ \\
\hline Potsdam sandstone. . . . . . . . . . . & $2-6$ & Chalk & \\
\hline Triassic sandstone............ & 4 & Granite . . & $\frac{1}{10} \sigma-\frac{1}{4}$ \\
\hline Trenton limestone........... & $\frac{1}{4}-1 \frac{1}{4}$ & & \\
\hline
\end{tabular}


Pl. III shows the appearance of two sandstone fragments under the microscope. The black portions in these sections represent what were originally open spaces between the grains.

\section{OCCURRENCE AND AMOUNT OF GROUND WATER.}

Occurrence.-The underground water which has been derived in the various ways outlined above occurs in the rocks under a variety of conditions. A part occupies the spaces along the bedding, fault, joint, and cleavage planes and a part occurs in the solution channels and caverns dissolved in the soluble rocks. The various fracture planes indicated, while very numerous in the aggregate, nevertheless comprise but a very small proportion of the open spaces within the rock, as they are limited to plane surfaces. The pores, or spaces between the particles which make up the rocks, are, on the contrary, everywhere present throughout the entire mass and constitute by far the larger proportion of the open space in the rock.

Amount.-In general, it is necessary only to penetrate a few feet of strata to reach a zone saturated with water, the depth depending upon the amount of precipitation, being least in regions of much rainfall and greatest in arid regions.

The downward limit of penetration of the water is dependent upon a variety of causes. It is frequently assumed that all rocks are saturated to great depths, the limit to which the water will penetrate being assumed to be that point at which the weight of the rock becomes so enormous that pores between the particles can not exist. This limit has been placed at about 6 miles. Practical experience in well drilling, however, shows that the assumption that all rocks are saturated below a moderate depth is far from being substantiated. In the Pennsylvania and New York oil regions, for instance, it is a very common experience to encounter, at a depth often of only a few hundred feet, rocks which are practically destitute of water. These include coarse-grained open sandstones, capable of holding large amounts, yet as far as can be determined they are absolutely dry, it being necessary in many instances to pour in from the top the water necessary for the process of drilling. In some instances after passing through these water-free rocks salt waters are encountered, but it is very rarely the case that fresh waters are found below the dry series. In some instances wells have been drilled several thousand feet without encountering any water whatever below the first few hundred feet. Although the rocks are far from being saturated, slight amounts of moisture are doubtless held in the pores.

Notwithstanding the fact that the depths to which the waters penetrate in quantities are probably much less than is frequently assumed, there is, nevertheless, an enormous amount of ground water. It has been estimated that the average pore space of the surface rocks is 


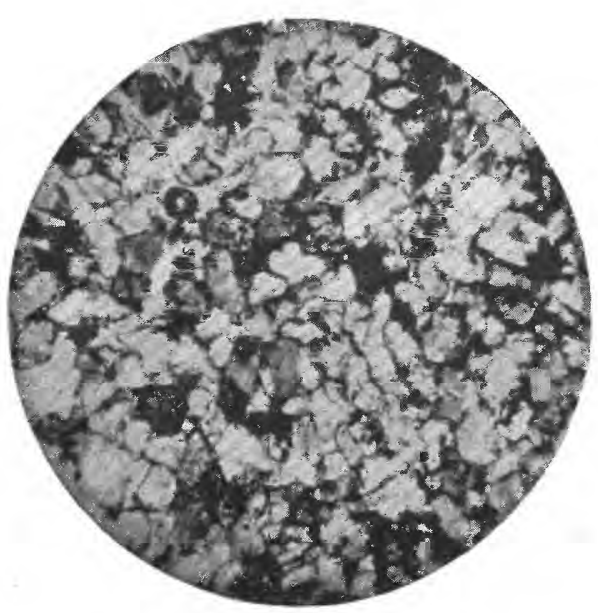

$A$

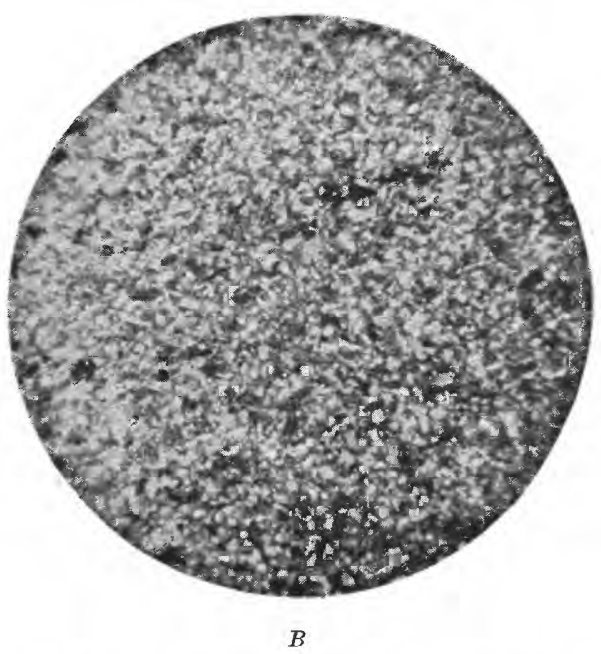

SANDSTONES VIEWED UNDER THE MICROSCOPE. 
about 10 per cent of their volume, but 5 per cent will probably be found to be more nearly correct.

\section{WATER-BEARING FORMATIONS.}

All rocks contain more or less water which, as pointed out, occupies either cavities in the rock or occurs between the minute pores. The water which occurs in the pores is given up readily only in the coarser rocks, such as sandstones, the fine-grained rocks yielding very little of such water when penetrated by the drill. In these rocks, the water, when found, usually comes from the joint, fault, or foliation planes. The conditions of the occurrence of water in the various rocks are very variable and are described in the following pages.

Sand and gravel.-Sands and gravels are very porous, 30 per cent of their volume frequently being made up of free space between the grains. In such materials the whole mass is saturated with water below the water level, and when penetrated by wells copious supplies are quickly yielded. The waters are generally of good quality, but are sometimes somewhat mineralized, the material being derived from the more soluble fragments and particles which constitute the deposits.

In passing downward through the sands surface waters are subjected to natural filtration, especially in the finer varieties, and the substances with which they may have originally been polluted are frequently removed. In the coarser types of sand, and in gravel, the water passes downward more rapidly, the conditions are less favorable for filtration, and the waters may remain polluted. In general, however, waters from sand and gravels, if taken from a considerable distance below the surface, are safe to use.

In the sands and finer gravels the cheapest and best method of obtaining water is by driven wells, which can be sunk quickly and at a very slight cost. In the very fine sands or quicksands, however, it is very difficult to exclude the material from the pipes, the quicksand frequently penetrating the well and clogging the pipe or ruining the pump. Because of the readiness with which sands and gravels yield their water, wells located close together frequently affect one another, the lower well or the wells which draw from the sand at the lowest points drawing the water from the higher wells. The readiness of movement of the water is also the cause of important fluctuations of level of the surface of the saturated zone, the water level often falling rapidly after wet seasons. To secure permanent supplies the wells should penetrate to the level which the water surface occupies in the driest seasons.

Clay.-Clay is very impervious to water, and in itself contains little or none which can be utilized as a source of supply. Water, however, is frequently reported in clays, but usually comes from more or less sandy layers. In some cases sand which approaches clay in 
fineness, and which is sometimes mistaken for clay, yields considerable amounts of water. Clay is of the greatest importance, not as a waterbearer but as a confining layer to porous sands, from which it prevents the water from escaping. The waters of clays, because of the fineness of the material, come into contact with relatively large amounts of mineral matter and frequently become mineralized, lime and salt being the most common substances dissolved. The waters of clays are, as a rule, free from contamination. When, because of the absence of other sources, it is necessary to obtain supplies from clay, a well should be sunk with as large a diameter as possible and continued beneath the point at which the water is obtained to a sufficient depth to furnish ample storage capacity, as clay waters are slight in amount and are yielded very slowly. Dug wells are usually most satisfactory where the clay is near the surface, but such wells should be carefully covered and guarded from all sources of pollution (see fig. 5).

Till.-Till is a heterogeneous mixture of clay, sand, gravel, and bowlders, deposited by glaciers in the northern portion of the coun-

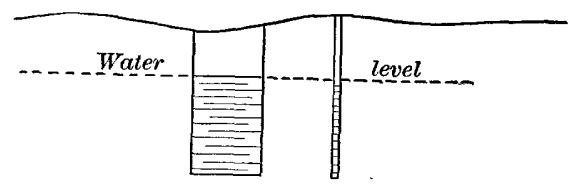

FIG. 5.-Relative size and storage capacity of dug and drilled weils. try. In texture it varies from porous to impervious according to whether sand or clay predominates. It is seldom definitely bedded. The water generally occurs in small more or less tubular channels a few inches in diameter, but occasionally is distributed through interstratified sandy beds.

In the aggregate the till yields a large amount of water, being the source of supply in the rural districts at a great number of points throughout the entire northern portion of the country. Because of the occurrence of the water in definite channels, however, the success of wells varies greatly. In general, wells of large diameter, similar to those described in the preceding paragraph, give the best success. Fig. 5 represents two wells of the same depth, one of the dug type and one of the bored type. It will be seen that in the well of the dug type not only is a larger amount of material encountered in cross section, but that the area of surface from which water can enter is many times greater than in the well of the bored type. The open well also presents larger storage possibilities, it being thus possible to utilize small supplies, which would be insufficient in the case of the bored well.

The water of the till is generally uncontaminated because in its downward penetration through the clay of which the till is in part composed it is subjected to natural filtration. If the water becomes polluted, however, it may retain its dangerous character for a long period of time and for considerable distances. 
Sandstone, conglomerate, and quartzite.-Sandstone is on the whole the best water-bearer of the solid rocks. Under the most favorable conditions the rock is saturated throughout its extent below the regular ground-water level, and water is yielded wherever the sandstone is struck by the drill within these limits. The water is yielded freely as a rule, although in some of the finer-grained sandstones it flows less readily. In quality the water averages better than in any other material except sand and gravels. It is almost never polluted, and wells can generally be safely used if they are cased to keep out the surface waters. The drilled type of well is utilized except where the sandstone is very near the surface.

Conglomerates sometimes furnish considerable water supplies, although as a rule their absorptive powers are not so great as those of sandstones, and they are much less frequently encountered. Quartzite is a sandstone in which the spaces between the grains have been filled by hard, siliceous matter. Because of the filling of the pores by this material there is relatively little chance for the water to enter, and the rocks are not commonly an important source of water.

Slate.-Slate, like clay, is a poor water bearer, but may yield water from bedding, joint, cleavage planes, etc. Its most important use, however, is as a confining layer to prevent the escape of water from porous sandstones which may be interbedded with it. The waters are reached by deep wells and are generally uncontaminated.

Limestone. - The waters of limestone occur mainly in open channels, caverns, etc, dissolved in the rock by the water itself. The water originally probably followed joint or bedding planes, which were gradually enlarged by solution into the caverns which we now find.

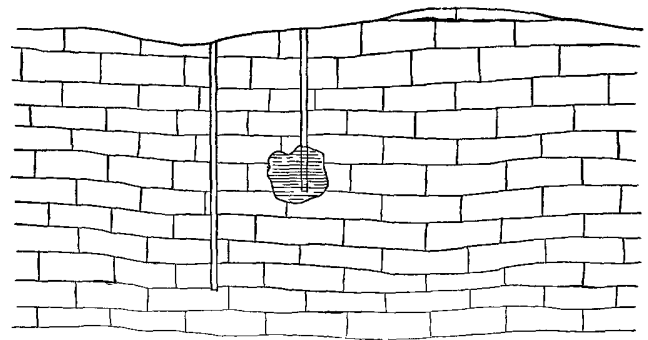

FTG. 6.-Difference in conditions of adjacent wells in limestone.

The occurrence of caverns and passages within the limestone is very irregular and their location can seldom be predicted. Most deep wells, however, which are drilled in limestone regions encounter one or more such passages at a relatively slight depth from the surface. Wells, even where only a few feet apart, nevertheless often obtain very different results, as a difference of a foot or two frequently means the missing of a certain channel, as indicated in fig. 6 . The waters are generally hard, but are not commonly otherwise mineral- 
ized. There is, however, a considerable likelihood of pollution, due to the fact that much of the waters of the underground streams in the limestone have found their way downward through sink holes, carrying with them more or less surface wash (see Pl. I, $A$ ).

Granite, gneiss, and schist.--The granites and gneisses are very dense and possess very small pore spaces, and the body of these rocks hold very little water. In schists, hówever, considerable water often pene-

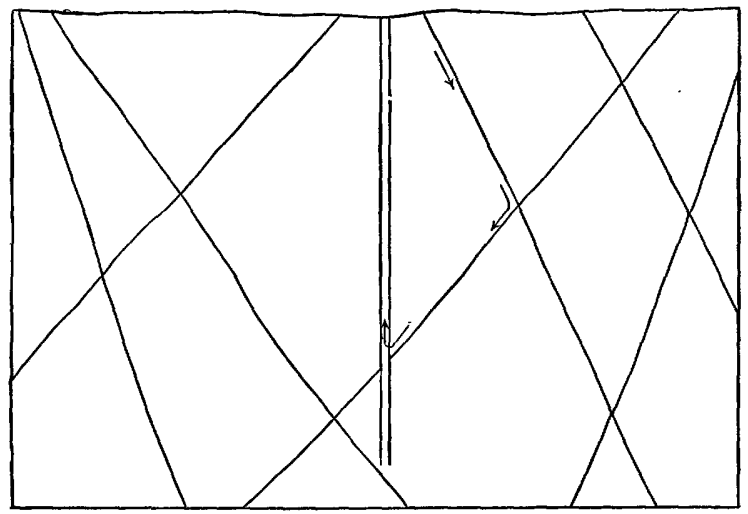

FIG. 7.-Well in jointed rock.

trates along the foliation planes and is held by the rock, but such water is given up very slowly and is not of importance as a source of supply.

It is along the joints that the largest supplies are obtained. These joints are most common near the surface and diminish in number and in definiteness as depth increases. For this reason the water supplies, if obtained at all, are generally found within 200 or 300 feet of the surface. It is generally useless to go deeper than 500 feet for waters in these crystalline rocks, although in some instances, as at Atlanta, water supplies have been obtained at depths as great as 1,600 feet. The joints generally occur in complex systems of intersecting planes, and it is possible for polluted water starting very near the mouth of the well to pass in a zigzag course downward along the joints, finally reaching the well at a depth of many hundred feet (fig. 7), as was the case in a well at Atlanta, Ga., which finally had to be abandoned. For this reason wells drilled in igneous rocks in cities and other thickly populated regions are liable to become polluted. Waters from such wells, if they are to be used for drinking purposes, should be tested occasionally to determine the possibility of pollution.

\section{TEMPERATURE OF UNDERGROUND WATERS.}

In all wells there is a certain depth, which differs in different localities, at which there is practically no difference in the temperature of the water from season to season or from year to year. This is known 
as the normal temperature of the water for a given region, and it agrees very closely with the mean annual temperature of the same locality. The depth of uniform temperature varies somewhat in different localities, but is commonly from 50 to 60 feet below the surface. The temperature varies from about $40^{\circ}$ or $45^{\circ}$ in New England to about $65^{\circ}$ or $70^{\circ}$ in the Gulf States.

Waters occurring nearer to the surface than the zone of uniform temperature vary in temperature according to season, being warmer than the normal in summer months and colder in the winter months. The temperature of waters warmer than the normal may also be due to the great depth from which the waters have come.

The main cause of rise in temperature below the line of invariable temperature is the internal heat of the earth. This internal heat increases rapidly downward, the rate of increase varying from $1^{\circ}$ in 30 feet to $1^{\circ}$ in 100 feet, the average increase being about $1^{\circ}$ to 50 feet. The temperature of the water is very little affected in passing through the upper 50 feet of its course, hence its temperature is a fair indication of the depth from which it is derived.

Besides the internal heat of the earth the heat of igneous masses below the surface of the earth has been thought to give rise to the hot springs of many localities, and in some instances the heat evolved by the chemical decay of rocks has been cited to explain the temperature of hot springs.

\section{RECOVERY OF UNDERGROUND WATERS.}

Water is returned to the surface in three general ways: (1) By seepage, (2) by springs, and (3) by wells. A brief discussion of each method is given in the following pages.

\section{SEEPAGE.}

Although a relatively obscure method, seepage is of great importance in returning water to the surface, especially in sands and gravels. Seepage water does not occupy definite channels, but fills the pores between the component grains of the various surface or other deposits. It emerges at the surface whenever the water level within the deposits becomes, through additions from rainfall, etc., higher than that of the lowest depressions or level of the surface. Sometimes, as on the south side of Long Island and elsewhere, the waters seep out from the sands over extensive areas along the shores a few feet above sea level. In such places the water frequently does not gather into definite channels, but forms more or less extensive fresh marshes, and gradually works its way into the sea. More frequently, however, seepage waters emerge in stream channels and other depressions. In some cases the water enters the stream at or just above the surface, but in most 
instances the main supply enters below the water level along the sides and bottom of the channel.

The distinction between seepage and springs is not sharp. The term "spring" is usually limited to those occurrences where the water comes out at a definite point; or at least emerges from a restricted area, but water that often appears at the surface as general seepage is often found, on excavating at its point of emergence, to come from a definite channel, and to approach a true spring in character.

SPRINGS.

Springs are not only exceedingly numerous throughout large portions of the eastern United States, especially in the more rugged regions, but form a most important source of water supply. In many of the hilly districts they constitute, in fact, almost the only source of domestic supply. In general they are free from pollution and not too strongly mineralized for ordinary uses. Mineral springs, however, are not uncommon, and are much used for medicinal and table purposes, and have lead to the development of sanitariums and many large and popular pleasure resorts.

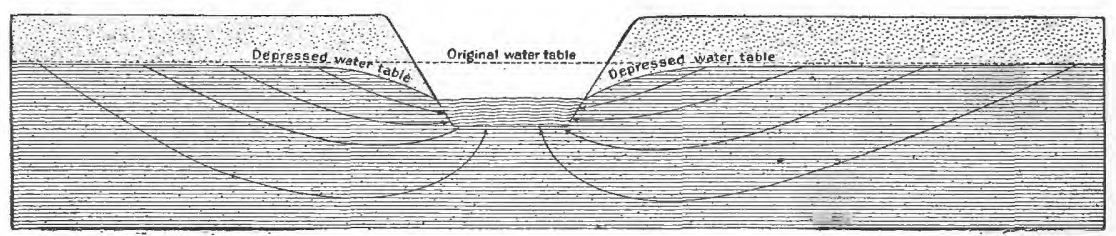

FIG. 8.-Lines of underflow into channel.

Seepage springs.-This term is applied when the water seeps out of sand or gravel, and differs from general seepage only in that it is restricted to a very small area. Such springs are usually marked by abundant vegetation at points of emergence, and the water as it collects is often colored or carries an oily scum due to the decomposition of vegetable matter. The scum is often mistaken for petroleum. Before using such a spring the vegetation should be cleared away and a small reservoir constructed, or tank sunk in the ground.

The waters of the seepage springs usually come from no great distance beneath the surface and are not usually very cold. Being fed by waters coming from near the surface they are sometimes likely to become polluted, and local conditions should be carefully studied before the water is used for drinking.

Seepage springs sometimes emerge along the top of an underlying impervious bed, but more frequently occur where valleys are cut downward into the zone of saturation of a more or less uniform water-bearing deposit, or where the water table comes to the surface near a stream, a lake, or the sea. Under favorable conditions the seepage from sands, as on Long Island, gathers into channels and forms streams of 


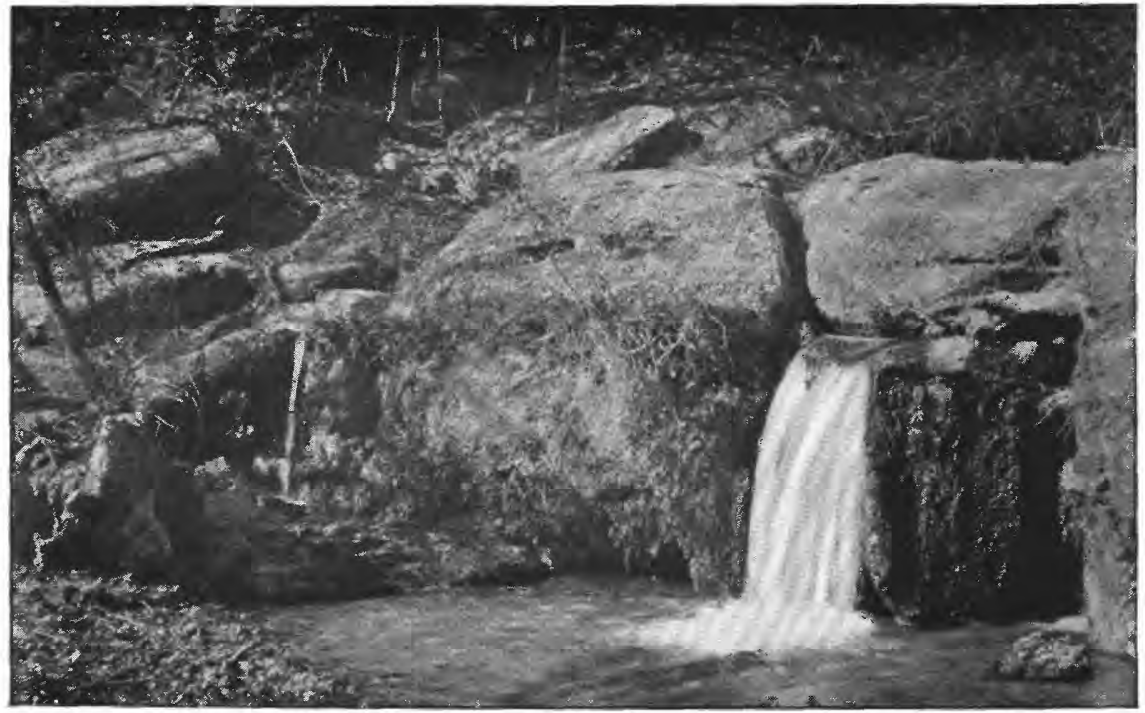

A. SPRING FORMED AT OUTCROP OF AN IMPERVIOUS FLOOR.

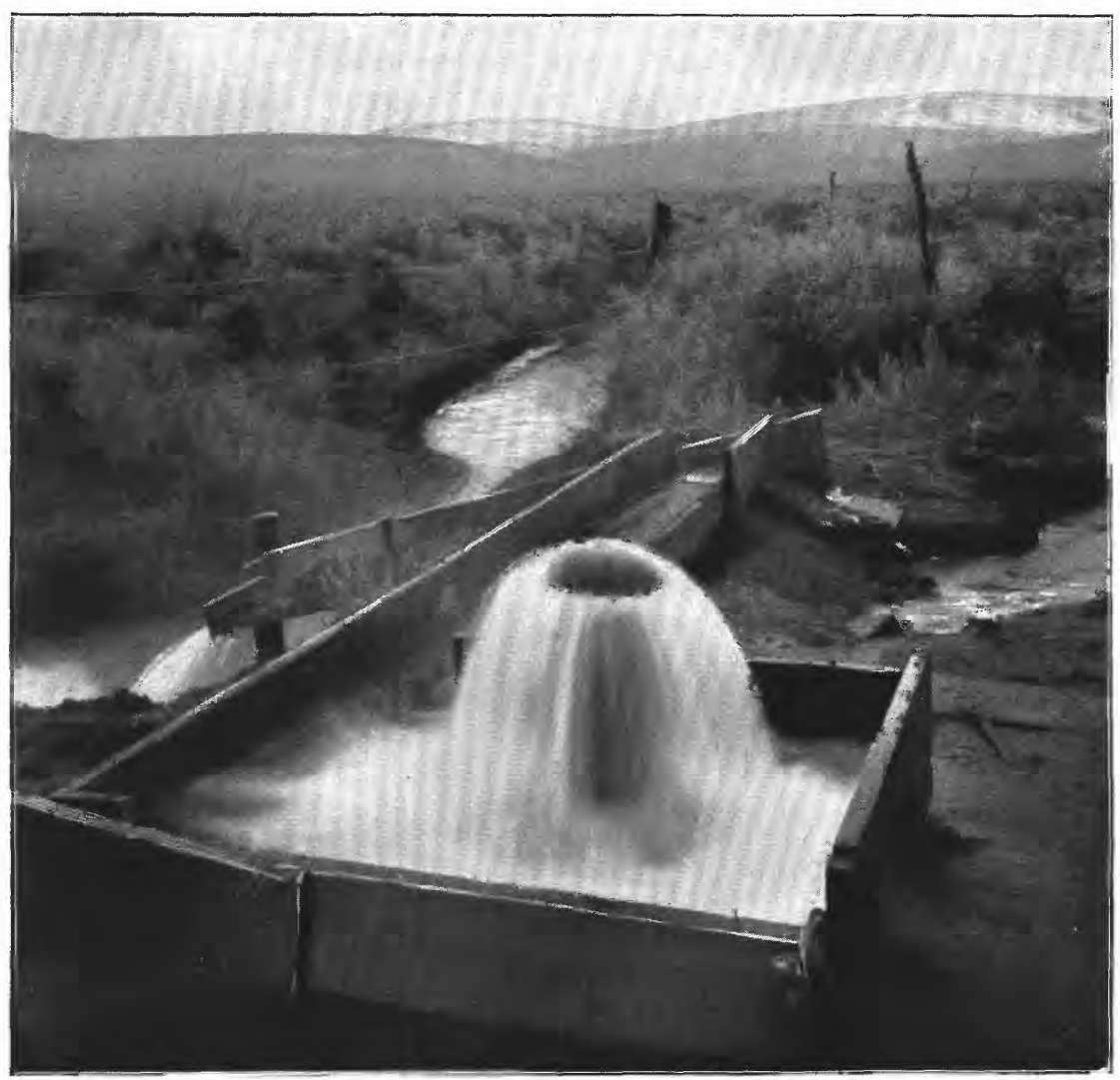

B. ARTESIAN WELL. 
considerable size, some of them flowing $5,000,000$ gallons or more daily.

Springs from definite underground channels.-In this group is embraced a great variety of springs, including both those flowing in the small more or less tubular passages in the drift, and those occupying large solution channels or caverns in the soluble rocks.

The channels of the drift springs are generally established along some more or less sandy or other porous layer, or even in places along the path left by a decaying root. At first the motion appears to be mainly by seepage, but in many instances a passageway is gradually opened along which a definite stream finds its way. The waters reach the channels by percolation through the clays and sands, and are usually free from pollution. If such a channel, however, leads from a cesspool, or similar source of pollution, the water becomes highly charged with matter dangerous to the health. Once contaminated it is likely to continue so for long distances, as little natural filtration takes place, owing to the nature of the channel. The water should be thoroughly tested by a chemist if there seems any likelihood of contamination.

In limestones and other soluble rocks the underground passages are often many miles in length. Single passages, as in the Mammoth Cave of Kentucky, have been traversed for a distance of nearly 10 miles, while passages as yet undiscovered, but several times as long, probably exist. Some of these passages are many feet in diameter and are traversed by streams of considerable size, or even rivers. The Silver Springs of Florida give rise to a river which is navigable from the ocean to its source in the springs, while springs of similar volume occur elsewhere in Florida and Arkansas, and possibly elsewhere. The waters of such springs vary greatly in composition, although most of them are hard. Some waters are exceedingly clear, the bottoms of springs being distinctly visible at a depth of many feet, but in others the waters are muddy after severe storms. In the first case it is probable that the waters feeding the underground stream reached it by percolation through the porous earth or rock, during which its impurities were largely removed. In the second case the waters in part appear to have penetrated downward through sinks, or entered the rock directly as streams. In both cases they are very liable to pollution by impurities washed in with the water (see Pl. I).

Fissure springs. - The term fissure springs is here used rather comprehensively to include the springs issuing along bedding, joint, cleavage, or fault planes (Pl. IV, A). The distinguishing feature is a break in the rocks along which the waters can pass, it being immaterial whether any considerable open space exists. These springs differ from the preceding in that they are as a class of deeper-seated origin. Seepage and drift springs are largely confined to unconsolidated surface de- 
posits, while the channels of limestone springs do not ordinarily extend much below the level of the surrounding surface drainage. In fissure springs, on the other hand, the waters are frequently derived from great depths, as is attested by their temperatures. The waters are almost never subjected to contamination, but are, however, often highly mineralized. Springs of this class are often scattered along

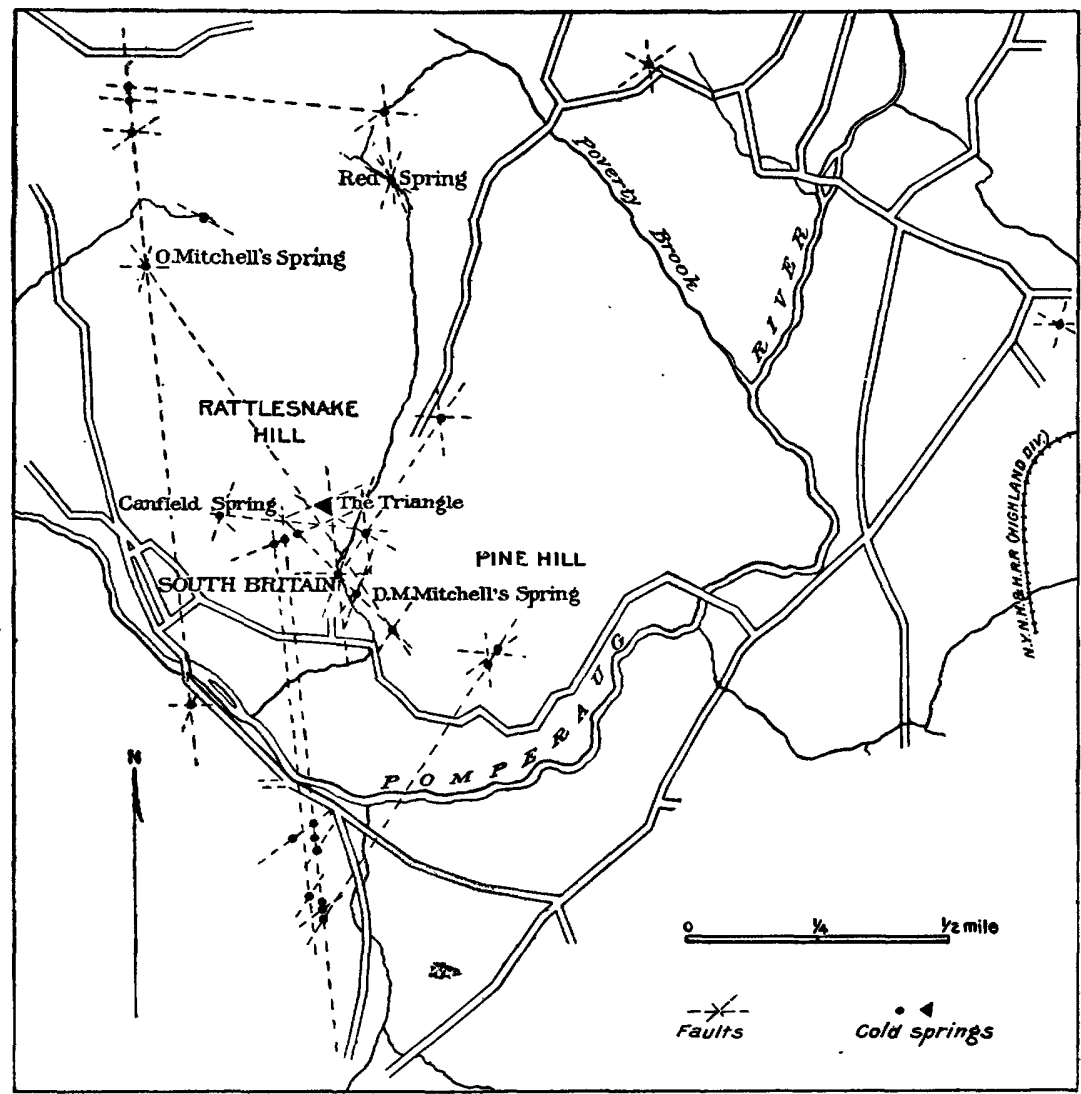

Fis. 9.-Map showing location of springs along faults or joints near South Britain, Conn. (After Hobbs.)

straight lines for considerable distances, their position being determined by lines of fracture or jointing, as shown in fig. 9 .

Geysers.-Geysers are those springs in which at more or less regular intervals the water is ejected with some force. The waters are always warm or hot and, therefore, come from considerable depth. Geyser springs generally emerge from tubular conduits that are lined with silica, deposited by the water, and end at the surface in a cone of similar material. The ejection of the water is probably due to the expelling force of steam generated deep below the surface under certain peculiar conditions. 
WELLS.

Wells are of three general classes: (1) Dug, (2) driven, and (3) drilled or bored. A few paragraphs will be devoted to their consideration, but detailed discussions will not be attempted.

Dug wells.-Dug wells are especially adapted to loose unconsolidated surface deposits in which the water supply is rather scanty. They present a large surface from which the water can enter and have a large storage capacity, but, on the other hand, they must necessarily be of limited depth, and because of the difficulty in keeping out surface and shallow-soil waters and other materials, are especially liable to pollution. They are also quite expensive and need to be frequently cleaned. They are undesirable if sufficient supplies can be had by driving or drilling.

Driven wells.-Driven wells consist of a pipe, with strainer and pointed end, which are driven into sand and similar soft deposits. They can be put down in a few hours, are exceedingly cheap, and effectively exclude surface waters. The principal difficulty arises from the penetration of sand and the clogging of the pipe. Driven wells furnish ideal supplies in many sandy regions, but are, of course, not adapted to the conditions existing over the greater part of the country.

Drilled and bored wells.-These include those wells drilled by machinery in rock or other deposits. Many different methods of drilling are employed, the one used at a particular point depending upon the material to be encountered or upon the nature of the well demanded. Among the most common are: (1) The ordinary churn-drill method, in which the drill is rapidly lifted and dropped, forcing its way down by impact; (2) the diamond-drill method, in which a cylinder set at the bottom with diamonds is rotated, cutting out a core of the rock; (3) the steel-shot method, in which loose chilled steel shot takes the place of diamonds, and (4) the jet process, in which a current of water is forced from the lower end of the pipe and by loosening the surrounding material allows the latter to sink. Many other methods or modifications are in use. Pl. IV, $B$, represents one of the deep drilled wells yielding flowing water.

\section{PUMPS.}

In raising water to the surface a variety of methods are used, but except for the bucket of the open wells they all depend upon some type of pump. Of the hand pumps, the ordinary valve pump, the chain pump, and the force pump are the most common. For raising large supplies windmills usually afford a cheap and satisfactory method on the farm, but in industrial establishments, where not only a large IRR $114-05-3$ 
but a constant and steady supply is needed, some form of power pump is used. Electricity, steam, and gasoline are all used, the latter being especially popular because of cheapness and ease of operation. Various forms of "air-lift" processes, by which water is lifted by a current of air that is forced into the well tubing, are successfully used.

\section{ARTESIAN FLOWS.}

\section{ESSENTIAL CONDIIIONS.}

Stratified beds.-In 1885 Prof. Thomas C. Chamberlin, in a paper entitled "Requisite and Qualifying Conditions of Artesian Wells," a explained the principles of artesian flow, and called attention to many of the special conditions which tend to determine the success or failure of these wells. The conditions which, according to Professor Chamberlin, may properly be considered as those of true artesian flow are as follows:

I. A pervious stratum to permit the entrance and the passage of water.

II. A water-tight bed below to prevent the escape of water downward.

III. A like impervious bed above to prevent the escape upward, for the water, being under pressure from the fountain head, would otherwise find relief in that direction.

IV. An inclination of these beds, so that the edge at which the waters enter will be higher than the surface at the well.

V. A suitable exposure of the edge of the porous stratum, so that it may take in a sufficient supply of water.

VI. An adequate rainfall to furnish this supply.

VII. An absence of any escape for the water at a lower level than the surface at the well.

Some of the features outlined above are illustrated by the following diagrams taken from Professor Chamberlin's report. There are many

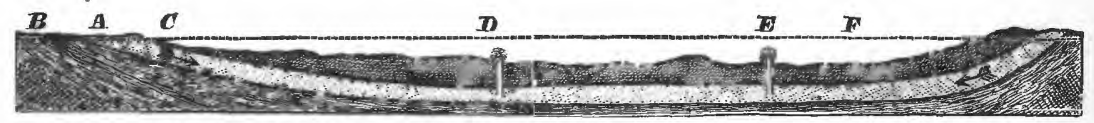

FIG. 10.-Section showing principal requisites of artesian wells. $A$, a porous stratum; $B, C$, impervious beds below and above $A$, acting as confining strata; $F$, height of water level in porous beds $A$, or, in other words, height of reservoir or fountain head; $D, E$, flowing wells springing from the porous water-filled bed $A$.

other minor conditions and modifications of the requisites outlined above which bear on the occurrence of artesian waters, but the essentials are here given.

Joirats and faults.-Flowing water is not confined to those wells which penetrate beds under the conditions outlined by Professor Chamberlin. The principle on which artesian waters depend is equally applicable to other rocks, the essential feature being simply that the water be confined and that the outlet through the well be considerably 
lower than the catchment area at which the water entered. A bedding, joint, or fault plane, or other fissure in insoluble rocks, or a solution passage in limestones, sometimes affords favorable conditions for artesian flows, although because of their commonly limited development

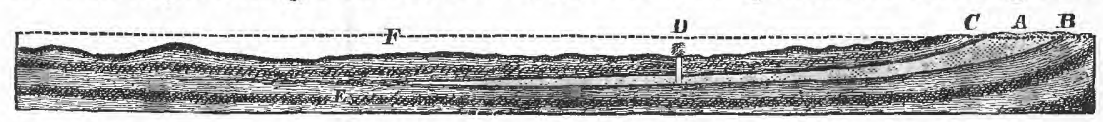

FIG. 11.-Section illustrating thinning out of porous water-bearing bed $A$, inclosed between impervious beds $B, C$, thus furnishing conditions for artesian well $D$.

they are far less frequently encountered than the broad porous sandstones and other sedimentary beds.

Besides occurring along bedding planes or along joint or fault planes water frequently follows a combination of passages, such as indicated in fig. 13, which shows an inclined bed cut by a joint, the motion of

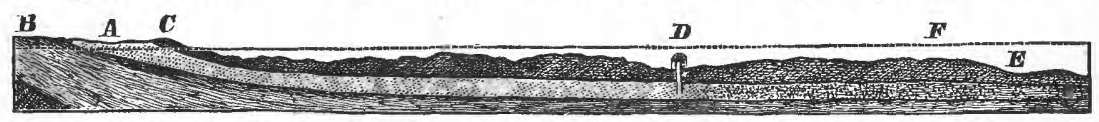

FIG. 12.-Section showing transition from porous to impervious bed. $A$, a close-textured,impervious bed, inclosed between impervious beds $B$ and $C$, furnishes conditions for an artesian well $D$.

the water being indicated by the arrow. Exactly the same conditions might occur if the bed $b$ were to be replaced by a joint or fault plane of the same position.

Direction of movement of water.-In the majority of cases the water encountered by wells is moving down the dip of the beds or down the

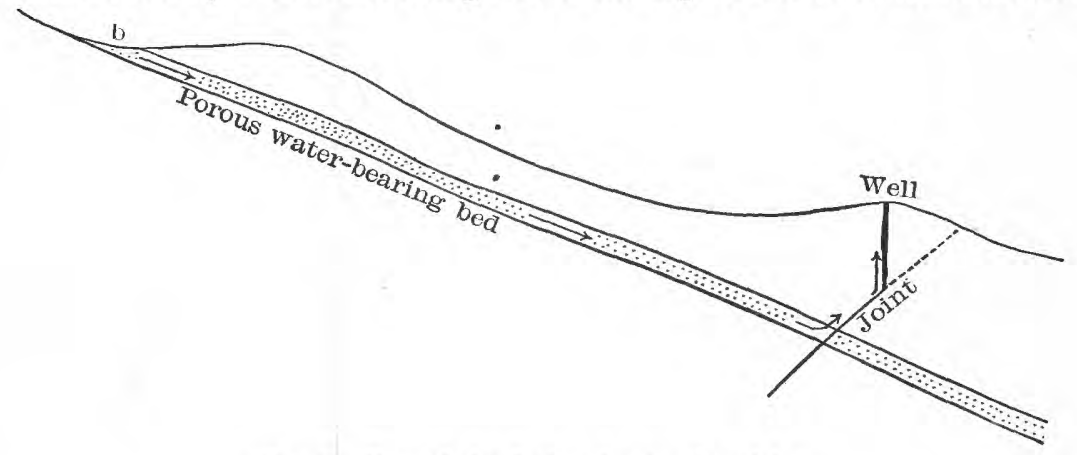

FIG. 13.-Upward circulation of water along joint.

joint or fault line, but in many instances, as in the cases outlined above and illustrated in fig. 13, the water may be moving upward.

\section{UNDERGROUND WATER CONDITIONS IN EASTERN UNTTED STATES.}

There are great differences in the underground water conditions in different parts of eastern United States. These are due in part to the presence in the northern half of a mantle of surface deposits left by glaciers or by streams connected with the ice. A part of the 
difference is also due to the difference in weathering of the rocks in the northern and southern portions, while still another part is due to variations in the character of rocks and of topography.

\section{AREA OF GLACIAL DRIFT.}

This area is bounded on the south by a line which, starting at Nantucket, passes through Marthas Vineyard, Long Island, across New

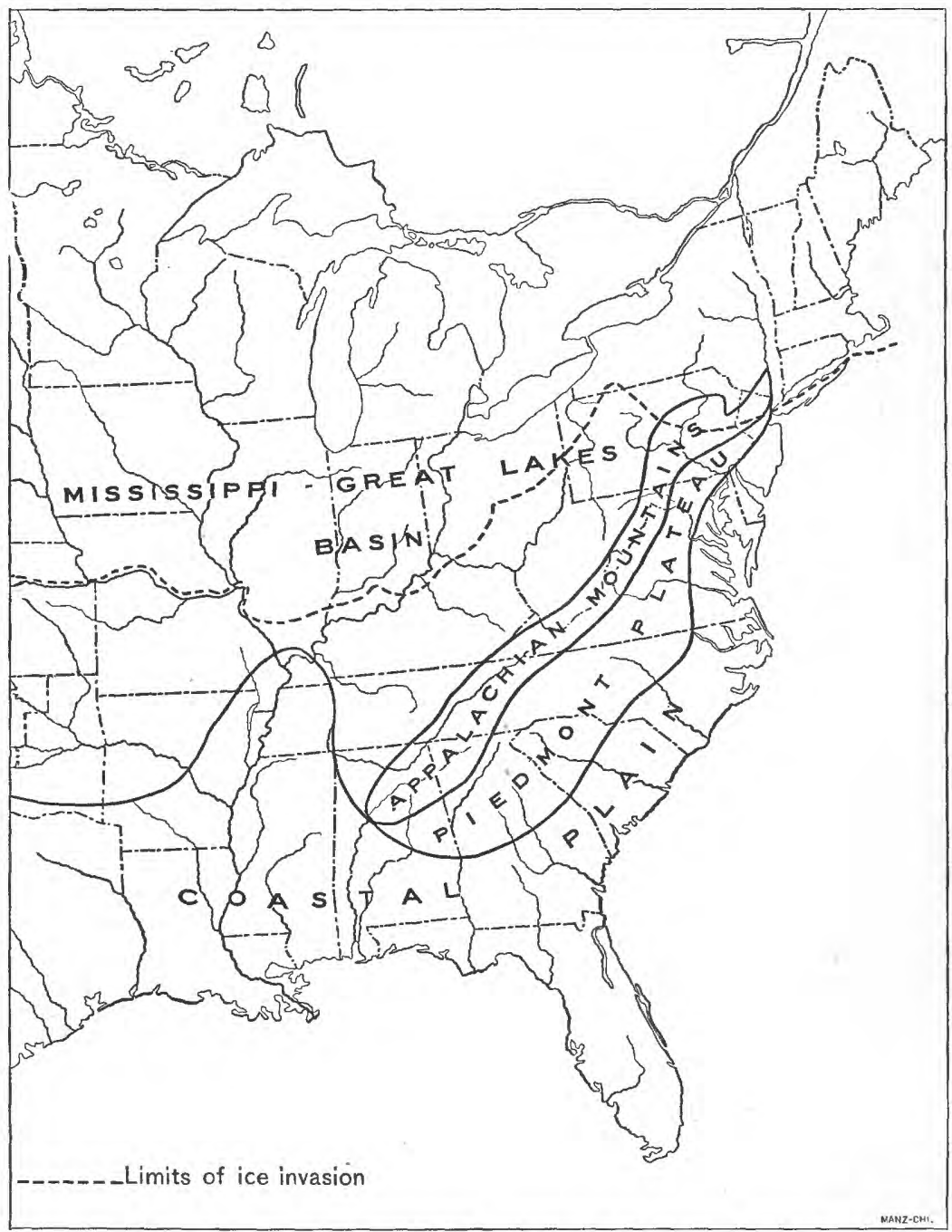

FIG. 14.-Geologic and water-supply districts in eastern United States.

Jersey, northwestward across Pennsylvania into New York, then southwestward across Pennsylvania and Ohio to the vicinity of Cincinnati, where it crosses the river for a short distance into Kentucky, 
thence westward across southern Indiana, Illinois, and central Missouri, to a point near Kansas City, where it leaves the region under consideration (see fig. 14). All of the region north of this line was covered one or more times by great ice sheets, except a small area in southwestern Wisconsin and adjacent portions of Minnesota, Iowa, and Illinois, where there appears to have been a sort of island of land surrounded by ice, known as the "Driftless area."

North of the boundary mentioned the surface, except for the small driftless area, is covered with a mantle of materials deposited by the glacier and known as drift. The drift is divjded into two main types, the first known as till, and the second as modified or stratified drift. Till is composed of a heterogeneous mass, consisting of clay, sand, and bowlders, frequently known as hardpan. It was deposited mainly directly by the ice, either beneath the sheet or at its margin. The second class of drift includes gravels, sands, and other stratified deposits formed by streams leading outward from the ice sheet. It is found chiefly along the valleys which were once occupied by glacial streams, but considerable amounts were also deposited in temporary glacial lakes which existed between the northward sloping land and the retreating ice sheet, while some was laid down as broad wash plains.

The glaciers which left the various types of drift started in the far north in relatively recent geologic times and spread southward to the limits mentioned. Before their advance the rocks were probably deeply weathered and covered with soil, as in the South at the present time, although the extent of the weathering was doubtless somewhat less. The first work of the ice was to remove this soft weathered material. Part was incorporated with the till and part was carried off by the streams to form clay and sand deposits. Later, after. the removal of the surface soil, the glacier began the work of wearing down the solid rocks, plucking off fragments both large and small from the ledges and transporting them southward. This material was also left in part in the till, and in part carried away by the streams.

The effect of the drift on the water supply of the northern portion of the country is very great. In general the drift holds very much more water than any of the rocks. This water is yielded readily to shallow wells, and furnishes by far the larger part of the well supplies in the region where it occurs. Water is least abundant in the till and most abundant in the stratified drift. Its occurence in till and in sand and gravel has already been described (see pp. 25-26).

WEATHERED ROCKS.

South of the limits of glacial advance the place of the drift is partly taken by the weathered or decomposed rocks. The weathering seems to be deepest in the south where the climate is more humid and, therefore, more favorable to rock decay. 
The soils south of the drift limits consist of small fragments or particles of disintegrated rocks. They are usually colored red and yellow by weathering and are very porous, absorbing much water. Their thickness, however, is not sufficient to make them a good source of water supply, although they yield water to many shallow wells. The water is subjected, as in sands and similar materials, to more or less complete filtration in its passage downward.

\section{ROCK WATER PROVINCES.}

Leaving out of account New England and eastern New York, which compare most nearly with the Piedmont Plain, the main divisions of the eastern United States, viewed from the standpoint of underground water supplies, are: (1) The Coastal Plain, (2) the Piedmont Plateau, (3) the Appalachian Mountains, and (4) the Mississippi and Great Lakes basin. The limits of these divisions are shown in fig. 14.

Coastal Plain.-The Coastal Plain consists of a strip of unconsolidated deposits, extending from Long Island on the north along the Atlantic and Gulf States into Mexico on the south. The width varies from a few miles at the north to several hundred miles in the Mississippi River region.

The surface of the Coastal Plain is low, usually not exceeding 100 to 300 feet above sea level and, where uncut by erosion, is generally flat. Owing to the soft character of the materials, however, the streams have generally cut fairly deep valleys. which are separated, where not too close together, by flat-topped ridges marking the original surface. Where the streams are close together the surface is cut into rolling hills.

The materials include clays, sands, gravels, marls, and a few more or less solid limestones, the latter being present mainly in the Southern States. A few of the sandy layers have been consolidated and now form sandstones. The beds dip gently toward the coast. The waters in the North occur mainly in sands and gravels, especially in those at the base of the Coastal Plain deposits. Farther south, particularly.in the Gulf States, water is found both in sands and in the porous limestones. The quality of the water in the gravels in the northern portion of the belt is generally soft and good, but farther south, notably where sands and gravels alternate with clay or limestone beds, the waters are often hard or are charged with sulphur and iron. The capacity of the wells is generally large and many of them flow without pumping. In the aggregate there are several thousand deep wells scattered throughout the Coastal Plain. They are used principally for domestic and farm supplies, but some of them that yield soft waters are utilized for industrial purposes. In the Gulf States, especially in Louisiana, a large number of wells furnish water for the irrigation of 
rice. A considerable number are also used as a source of public water supplies.

Piedmont Plateau.-The Piedmont Plateau proper consists of a belt of crystalline rocks, including a few small basins of Triassic sediments, that extends southward from southeastern New York along the east front of the Appalachian Mountains to Alabama, lying between the mountains and the Coastal Plain. Where the plateau joins the Coastal Plain its elevation is only a few hundred feet, but the altitude of its surface increases gradually toward the northwest, until at the base of the mountains, especially in western North Carolina and vicinity, its highest points have an altitude of several thousand feet. In the main its surface, where uncut by streams, is flat or gently rolling, but in its higher portions it has been cut into a series of prominent mountains. In the vicinity of the streams near the coast it is also cut into a series of lower hills, as in the case of the Coastal Plain.

The rocks of the Piedmont Plateau proper consist mainly of schists, gneisses, granites, and other metamorphic or igneous rocks, all of which are of crystalline texture. The rocks of the Triassic basins consist mainly of sandstones, shales, etc.

The waters of the Piedmont Plateau are relatively uncertain in occurrence, depending largely on the existence of joints or other fissures in the rocks, but good supplies have nevertheless been obtained at numerous points. In composition the waters are usually fairly good, although they sometimes contain considerable mineral matter. Relatively few deep wells have been sunk in this region, owing to the uncertainty of supply, dependence being placed largely on streams or on shallow wells dug in the weathered upper portion of the rocks. The waters are used largely for domestic and farm purposes and in small industrial establishments. In a few places public water supplies are obtained from the Piedmont rocks, and some important mineral springs are found in the region.

Similar to the Piedmont Plateau are the great areas of igneous rocks in Minnesota and Wisconsin and in New York and New England. The topography of the rocks in these regions is in general somewhat more rugged than in the Piedmont Plateau proper, and less use is made of the waters, largely because of the abundance of lakes, springs, and spring-fed streams, or of waters in the glacial drift which overlies the erystalline rocks in this portion of the country.

Appalachian Mountains. - The Appalachian Mountains may be considered as beginning in eastern Pennsylvania and extending southward to central Alabama. The Berkshire Hills in Connecticut and Massachusetts and the Green Mountains in Vermont are included in the area by some. The rocks throughout the region are strongly folded and broken by faults, the harder beds giving rise to the great mountain ridges 
which characterize the belt. The rocks consist of quartzites, sandstones, shales, and limestones. The sandstones and certain of the limestones carry considerable amounts of water, but are seldom used as a source of supply. The water in the limestones is carried in definite channels and is of rather uncertain occurrence. Both the sandstones and limestones yield copious springs in places. Wells in the synclines or rock troughs frequently yield water which will sometimes rise to the surface, but in general dependence is placed on the springs which occur in large numbers throughout the belt. In the wider limestone valleys wells or cisterns are often used. There are very few cities or large industrial establishments in this region and deep wells are therefore somewhat rare.

The Mississippi-Great Lakes basin.-This basin includes the remaining portion of the territory in the eastern half of the United States. The surface is moderately low, seldom exceeding 1,000 feet in elevation, and is usually not characterized by prominent hills or mountains. Except in the areas of igneous rocks, noted above, the rocks consist of flat or very gently folded sandstones, limestones, shales, etc., varying from Cambrian to Carboniferous in age. The Cambrian and other of the older sandstones carry large amounts of water, which is obtained by wells that frequently flow at the surface. The Silurian limestones also contain considerable water, but, as is the case with water in limestones elsewhere, its occurrence at a particular point can seldom be predicted.

The younger rocks, including the Devonian and Carboniferous, consist to a considerable extent of alternations of shales, shaly limestones, and sandstones. In the limestones the water occurs very much as in other limestones. In the sandstones and shales, however, its occurrence is uncertain owing to the lack of persistence of the beds. One well may obtain water, while another a few feet away may fail. The waters are often mineralized, especially in Michigan, where they contain a high percentage of salt. The Carboniferous limestones abound in springs, some of which are of great size. 


\section{MAINE.}

\section{By W. S. BAyLeY.}

\section{TOPOGRAPHY AND GEOLOGY.}

The surface of Maine consists essentially of an extensive southwardfacing slope draining directly into the Atlantic Ocean and a smaller northward-facing slope draining into St. John River. The latter area is a great plain corered largely by swamps and interrupted by a few irregular-shaped hills. The surface of the southern slope is much more broken. It is crossed by many ridges of low mountains trending east or northeast, some of which rise several thousand feet above the platform on which they rest. These are separated by wide areas of plain, on which are many small glacial hills and ridges. Near the coast the surface is rough. Rocky ridges and low, bare hills stretch from the shore line some miles inland, but the hills are not lofty and the valleys between them are not deep.

All the rocks are Paleozoic or older, except the very late marine clays and the glacial deposits. The northern portion of the State is underlain by moderately folded Silurian and Devonian limestones, shales, and sandstones, cut here and there by igneous rocks, some of which are certainly volcanic. In this area the conditions are the most favorable for the occurrence of artesian waters.

The section bordering the coast is underlain by granites, gneisses, crystalline scbists, and ancient lavas intersected by intrusives. The central portion of the State, between the northern and the coast belts, is composed of slates, quartzites, and impure limestones, very much like the rocks in the northern belt, but usually more crystalline and more closely folded. These, too, are cut by granites and other intrusives. Conditions are not so favorable for artesian water in the central and the coast belts as they are in the northern belt; nevertheless, in some areas within them, where the rocks are less highly tilted than elsewhere, or where they are much fissured, artesian waters have been developed. Springs, moreover, abound and a few drilled wells deliver water at the surface. 
Upon the rocks of all three belts the glaciers that once covered the entire State deposited clay, sand, gravel, and a mixture of clay and bowlders. The latter constitutes the till, which covers all the older. rocks as a blanket, varying in thickness from a few inches to many feet. The clay, sand, and gravel form terraces, hills, and ridges that run in gently sinuous lines for long distances over hill and valley, following; in the main, the directions of the principal drainage lines. In these deposits the various components are often interstratified, furnishing ideal conditions for successful shallow wells. Most of these wells obtain water either from the sand and gravel layers interleaved between the clay beds or from the rock surface underlying all the sediments.

The only remaining rocks that are at all widely spread in Maine are the beds of fossiliferous marine clays, which extend far inland up the river valleys and into lowlands where the elevation is not more than 230 feet above sea level. Over these clays are layers of river sand, deposited at a time when the streams were being fed by the melting glaciers. At the base of this sand, where it lies upon the clay, there is usually a constant sheet of water moving slowly riverward. This furnishes an unfailing source of supply to wells situated near the river banks, but unfortunately the water is often contaminated with impurities of various kinds.

\section{WATER SUPPIYY.}

With the exception of Florida, Maine is the least densely populated of all the Eastern States. Because of this low density (23.2 per square mile) and its abundance of lakes and streams, its people have felt little necessity for seeking sources of water supply below the surface. Consequently, the underground waters of the State have been, on the whole, but slightly utilized, except in certain restricted areas, where, for one reason or another, the surface waters are not suitable for domestic or manufacturing purposes.

Until very recently the rivers and lakes have afforded excellent water for nearly all purposes. With the increase in the number of factories established on the main waterways for the advantages resulting from the possession of cheap water power, the rivers have become less and less valuable as sources of water supply, partly because of the waste products poured into them from the factories and partly because of the increased amount of sewage which they must carry in consequence of the growth of the manufacturing communities on their banks.

The drift of the population toward centers is well shown by the census of 1900. The number of cities and villages separately enumerated in this year was 43 , as against 25 in 1890 , and their population was 258,431 , as against 184,821 , or 37.2 per cent of the total population in 1900 , as against 28 per cent in 1890. 
The natural result of the two tendencies above mentioned has been to pollute the principal water courses, with the consequent result that communities drawing their public supplies from streams are beginning to complain of the quality of the water furnished them and are turning toward the lakes for relief.

Along the coast strip, where the larger rivers are tidal, communities are dependent upon lakes and small brooks for their public supply. On the islands the principal sources of drinkable water are springs and drilled wells, but since there are only a few island settlements of any considerable size the question of large public supplies is not of great moment.

Within the interior of the State village communities that are not situated near large lakes or spring-fed brooks have often taken advantage of the numerous good springs that abound everywhere and spring water has been piped through the settlements.

\section{PUBLIC SUPPLIES.}

The aggregate population furnished by water corporations from the three principal sources above mentioned is about 285,000 , or about 40 per cent of the entire population of the State. Of this number about 152,000 obtain public water from lakes, 122,000 from rivers, and 14,000 from springs. In addition there is one community (Castine, population about 900 ) that draws its supply from four drilled wells. 


\section{RIVERS.}

The communities at present obtaining their public supply from rivers and brooks are as follows:

Preliminary list of communities drawing upon streams as the sources of their public water supply.

\begin{tabular}{|c|c|c|}
\hline Place. & County. & Source of supply. \\
\hline Augusta . & Kennebec & Kennebec River. \\
\hline Bangor . . . & Penobscot & Penobscot River. \\
\hline Belfast ... & Waldo ... & Little River or Coles Brook. \\
\hline Bethel & Oxford .. & Chapman Brook. \\
\hline Benton .... & Kennebec & Messalonskee River. \\
\hline Biddeford & York ..... & Saco River. \\
\hline Brewer... & Penobscot. & Penobscot River. \\
\hline Calais .... & Washington & St. Croix River. \\
\hline Caribou & Aroostook. & Aroostook River. \\
\hline Dover..... & Piscataquis. & Piscataquis River. \\
\hline Ellsworth ...... & Hancock . & Branch Pond Stream. \\
\hline Ellsworth Falls. & $\ldots$ do ... & Do. \\
\hline Fairfield. . & Somerset & Messalonskee River. \\
\hline Freeport & Cumberland & Brook. \\
\hline Fryeburg . & Oxford .. & White Lot Brook. \\
\hline Gardiner . & Kennebec. & Cobossecontee Stream. \\
\hline Oldtown.. & Penobscot . & Penobscot River. \\
\hline Houlton . & Aroostook & Moose Brook. \\
\hline Kingfield. & Franklin .. & Brook flowing into Tuffs Pond. \\
\hline Milltown .... & Washington & St. Croix River. \\
\hline Old Orchard. & York..... & Saco River. \\
\hline Pittsfield . & Somerset . & Sebasticook River. \\
\hline Presque Isle & A roostook & Kennedy Brook. \\
\hline Richmond.... . & Sagadahoc. & Kennebec River. \\
\hline Rumford Falls. & Oxford ... & Androscoggin River. \\
\hline Saco $\ldots . . . . .$. & York.... & Saco River. \\
\hline Somerville..... & Lincoln ... & Sheepscot River. \\
\hline Sorrento...... & Hancock .. & Piscataquis River. \\
\hline South Berwick. & York...... & Two Brooks. \\
\hline Van Buren & Aroostook & $\begin{array}{l}\text { St. John River and Violette } \\
\text { Brook. }\end{array}$ \\
\hline Waterville. & Kennebec & Messalonskee River. \\
\hline
\end{tabular}




\section{LAKES.}

The list below is an enumeration of the communities utilizing lakes as their sources of supply.

Preliminary list of communities utilizing lakes as sources of water supply.

\begin{tabular}{|c|c|c|}
\hline Place. & County. & Source of supply. \\
\hline Auburn & Androscoggin & Lake Auburn or Wilton Pond. \\
\hline Bar Harbor........ & Hancock .. & Eagle Lake. \\
\hline Bath ..... & Sagadahoc.. & Lake Nequassetto. \\
\hline Bath (emergency) & .....do & 120 driven wells. \\
\hline Belgrade .... & Kennebec .. & Belgrade Lake. \\
\hline Boothbay Harbor ...... & Lincoln ..... & Adams Ponḍ. \\
\hline Brunswick. & Cumberland & \\
\hline Camden . & Knox ..... & Mirror or Oyster River Lake. \\
\hline Gorham ... & Cumberland . & Sebago Lake. \\
\hline Kittery ..... & York....... & Folly Pond. \\
\hline Lewiston . & Androscoggin . & Lake Auburn. \\
\hline Livermore Falls. & .....do .... & \\
\hline Newport. & Penobscot ... & Pillsbury Pond. \\
\hline Norway .. & Oxford ....... & $\begin{array}{l}\text { Norway or Great Pennessee- } \\
\text { wassee Lake. }\end{array}$ \\
\hline Oakland. & Kennebec . & Messalonskee Lake. \\
\hline Phillips . & Franklin ... & Mount Blue Pond. \\
\hline Portland & Cumberland & Sebago Lake. \\
\hline Rockland. & Knox ... & Mirror or Oyster River Lake. \\
\hline Rockland (auxiliary). & ..... do .. & Lake Chicawanstin. \\
\hline Rockport .... & ..... do .... & Mirror or Oyster River Lake. \\
\hline Seal Harbor & Hancock & Jordan's Pond. \\
\hline South Portland. & Cumberland & Sebago Lake. \\
\hline South Paris ..... & Oxford & Norway Lake. \\
\hline Southwest Harbor. & Hancock & Long Pond. \\
\hline Thomaston ... & Knox . & Mirror or Oyster River Lake. \\
\hline Westbrook ... & Cumberland . & Sebago Lake. \\
\hline Wilton ....... & Franklin ............ & \\
\hline Woolwich .... & Sagadahoc.. & Lake Nequassetto. \\
\hline York ........ & York... & Chase's Lake. \\
\hline York Corner.... & $\ldots$... do ...... & Do. \\
\hline
\end{tabular}




\section{SPRINGS.}

In the communities named below springs furnish nearly all the water used. In all cases this is carried by pipes either directly from the springs or from reservoirs into which the spring water is pumped.

Preliminary list of communities obtaining their public supply from springs.

\begin{tabular}{|c|c|c|}
\hline Place. & County. & Remarks. \\
\hline Addison ...... & Washington - & \\
\hline Appleton . & Knox ..... & \\
\hline Bingham . & Somerset ... & 2 springs fill $1 \frac{1}{2}$-inch and 6 -inch pipes. \\
\hline Brownville & Piscataquis .. & 3 springs; piped to hotel and private \\
\hline Cherryfield . & Washington & \\
\hline Fort Fairfield & Aroostook & \\
\hline Guilford... & Piscataquis . & Supplies 30 families. \\
\hline Hallowell ... & Kennebec... & \\
\hline Harrington ... & Washington & \\
\hline Lisbon Falls . & Androscoggin & \\
\hline Lubec....... . & Washington . & 350,000 gallons a day. Temperature, $42^{\circ}$. \\
\hline Millbridge ... & ..... do ...... & Fills 2-inch pipe. Temperature, $40^{\circ}$. \\
\hline Monson & Piscataquis .. & Supplies 30 families. \\
\hline North Waterb & York...... & \\
\hline Paris Hill .... & Oxford ..... & From 10,000 to 30,000 gallons a day. \\
\hline Peru ....... & ..... do ...... & \\
\hline Sanford .... & York ...... & Fills $\frac{1}{8}$-inch and $\frac{3}{4}$-inch pipes. \\
\hline Sangerville . . & Piscataquis .. & \\
\hline Searsmont ... & Waldo ...... & \\
\hline Searsport ... & ..... do .... & - \\
\hline Skowhegan & Somerset ... & 500,000 gallons a day. \\
\hline Springvale... & York....... & 100 gallons a minute. \\
\hline Stratton ..... & Franklin ... & \\
\hline Union ....... & Knox ..... & \\
\hline Winterport . . & Waldo ..... & 125,000 gallons a day. \\
\hline Yarmouth... & Cumberland. & 120,000 gallons a day. Temperature, $49^{\circ}$. \\
\hline Yarmouthville & ..... do .... & \\
\hline
\end{tabular}

\section{DRILLED WELLS.}

The village of Castine is furnished with water for domestic and fire purposes by four drilled wells, of which three, situated at an elevation of 130 feet, are now used. In these the water was struck at a depth of $62 \frac{1}{2}$ feet, or $67 \frac{1}{2}$ feet above mean high-water mark. It rises naturally within 25 feet of the surface and is pumped to the surface with the aid of a windmill. These wells yield 40,000 gallons daily. 
A fourth well, 675 feet deep, is located at an elevation of 217 feet. Water was struck in this well at a depth of 620 feet. It apparently came from fissures in the rock. The water level in this well is only 27 feet below the surface-i. e., it is $127 \frac{1}{2}$ feet higher than the level in the lower wells and 190 feet above sea level. All the wells are situated on the backbone of a small peninsula that extends into Penobscot Bay. This peninsula is only 2 miles long and 1 mile wide, and is joined to the mainland by a narrow isthmus which has been crossed by a canal. The deepest well, whose water rises 190 feet above sea level, is only half a mile from the shore of the bay.

\section{PRIVATE SUPPLIES.}

The farming communities in Maine, as elsewhere in the Eastern States, consist of isolated families or very snlall groups of families in villages that are not large enough to warrant the wholesale distribution of water. Water can not be conveyed to them economically from long distances, hence their supplies must come from near-by sources, which are available almost everywhere immediately beneath the surface. These underground sources are tapped by dug and by drilled wells, or by the natural fissures through which springs issue.

\section{DUG, DRIVEN, AND BORED WELLS.}

The soil covering of Maine is largely glacial in origin. The drift which covers the hard rocks is of considerable thickness over most of the State, and from its nature it affords many reservoirs for the storage of ground water. Where gravels and sands are intercalated between clay beds these furnish abundant water. The depth of the layers from which the water is derived varies widely even in the same neighborhood, because the coarse-grained beds are not of great horizontal extent, and neighboring wells, therefore, must often obtain their water from different layers. In those places where the drift covering is thin the rock under the drift is blasted into, and in this way a shallow basin is made, into which water seeps from the basal layers of the overlying drift and from the crevices opened up in the rock.

In the valleys of many of the rivers are deposits of clay, which were either laid down by the rivers themselves or by bays of the ocean which formerly extended inland up the river valleys. Between the successive beds of clay are often thin layers of water that are continuously flowing riverward as broad sheets. Where these are intercepted by wells an abundant and constant supply of water is obtained. Wells of this class possess, in a measure, artesian characters. The water often rises above its immediate source, and its height is only slightly affected by droughts. On the other hand, the beneficial effect of sand filtration upon the water is lacking, and consequently these wells are more apt to become polluted than those that obtain their 
water by tapping supplies in sand or gravel. A rapid examination of the records of the State board of health shows that the greater proportion of the polluted wells investigated by the board are those which obtain their water from between clay layers; whereas, on the other hand, the wells obtaining their supply from the sand beds in the drift usually furnish good water, although they may be situated in the midst of farm buildings that have occupied the land for periods of fifty or seventy-five years.

DRILLED WELLS.

Because of the abundance of streams, lakes, and springs in the State, and the ease with which the underground water in the glacial drift may be reached by dug, driven, and bored wells, the use of drilled wells is not common. There are a few in the interior counties where the supply of surface water is not constant and where the drift is thin and dug wells are likely to fluctuate with variations in the amount of rainfall, but by far the greater portion of the deep wells are situated either on the islands off the cost or in a narrow strip on the mainland bordering the shore. This shore strip is almost insular in character. Deep inlets extend back into the land, separating it into narrow tongues that are almost surrounded by salt water. Moreover, the drift covering is usually thin, and in this belt, as on the islands, the collecting areas are small and the capacity of the drift for storage is small.

Records of the rocks drilled through have been kept for very few of the wells. This fact, together with the fact that the geology of the State is practically unknown, makes it impracticable to work out at present the limits of artesian basins. From the scanty data at hand, however, it appears probable that at least one basin exists in the northeastern part of the State, in the eastern portion of Aroostook County, and another in the west-central part, surrounding Moosehead Lake.

At Greenville, at the mouth of Moosehead Lake, are two wells that flow. These two and a few others in the coast belt are the only ones that furnish water at the surface. In the great majority of the wells, however, the water is forced upward by natural pressure some distance above its source.

Of the 448 drilled wells of which reports have been received, 134 are 100 feet deep or over. Of these there are 2 over 500 feet deep, 7 between 300 and 400 feet, and 25 between 200 and 300 feet.

\section{SPRINGS.}

Throughout the interior of the State springs are frequently used as sources of water supply when they are situated at a greater elevation than the buildings to be furnished with water. Often several families combine and hare the water of the larger springs distributed through their dwellings by pipes. Occasionally the water is raised by wind- 
mills, but usually it is distributed by gravity alone. In those portions of the State where the well water is hard, springs are more generally utilized than in those portions where the well water is soft. In a few instances where the quality of the water in the streams near by is poor, springs supply water for manufacturing establishments.

Very important springs, which are of great economic value to the

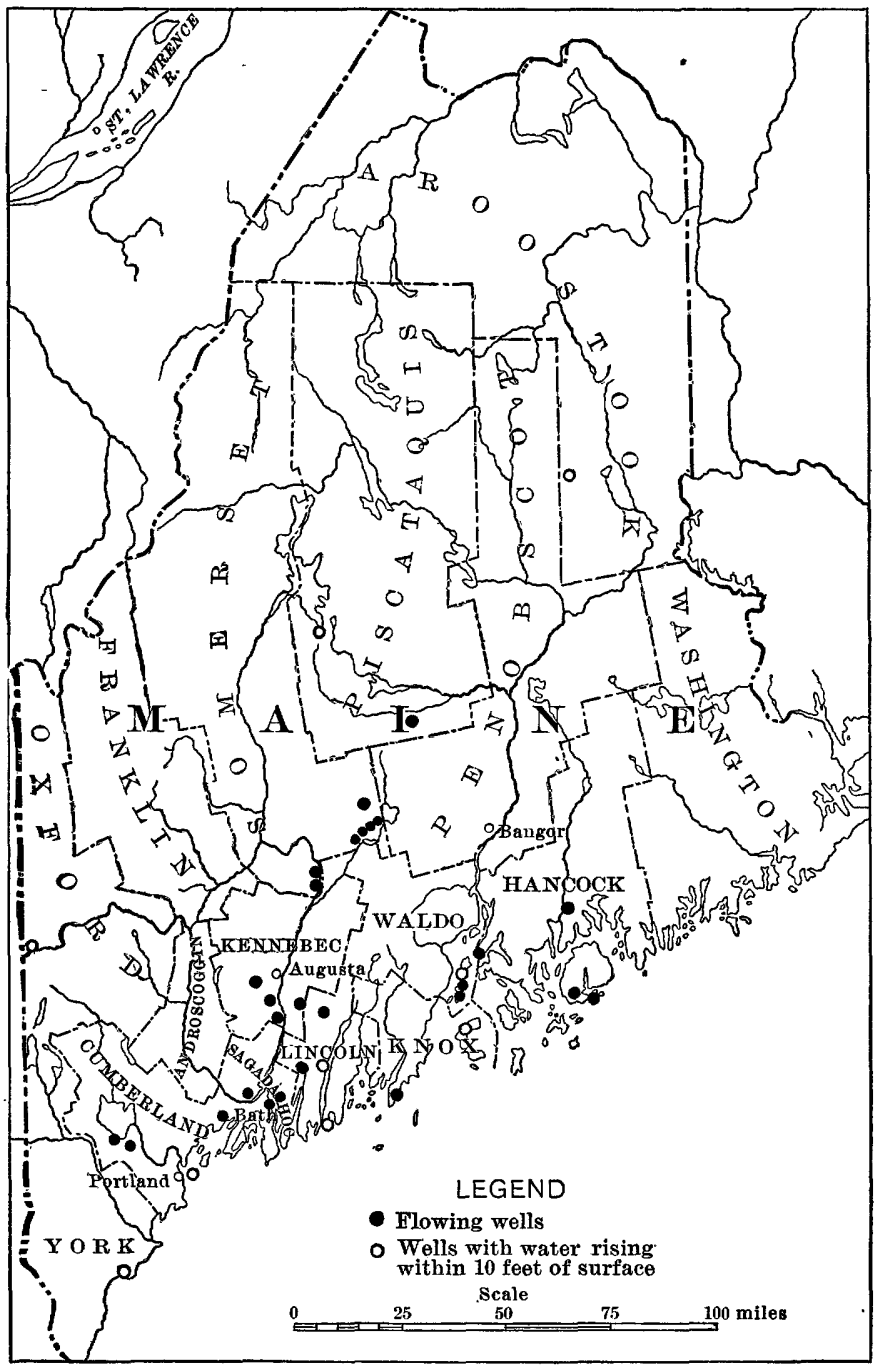

FIG. 15.-Location of flowing or nearly flowing wells of Maine.

State, are those which may be denominated commercial springs. This group includes those springs whose waters are sold by measure, i. e., in small parcels. Of this class there are two subclasses. In the first are included springs that furnish water to consumers in their vicinity 
at regular intervals, to be used as table water. In this group there are at present known to be 25 springs, from which 486,000 gallons are sold at a cost to the consumers of $\$ 29,782$. A list of these, with analyses of their waters, is given in the table on pages 51 to 53 . The second subclass includes springs whose waters are bottled and shipped to distant points. The mineral springs whose waters are supposed to possess medicinal properties are included here, and also certain other springs whose water is exceptionally pure. The quantity of water shipped from these in 1902 was 355,865 gallons, valued at $\$ 71,415$. This amount does not include the sales of water from Poland Spring, the proprietors of which decline to make any statement as to the quantity or value of the water supplied by them to consumers. It is known, however, that the aggregate value of the water shipped from this spring is greater than that of all the other springs in the State. The springs in this group number 22 . (See table on page 54.) 


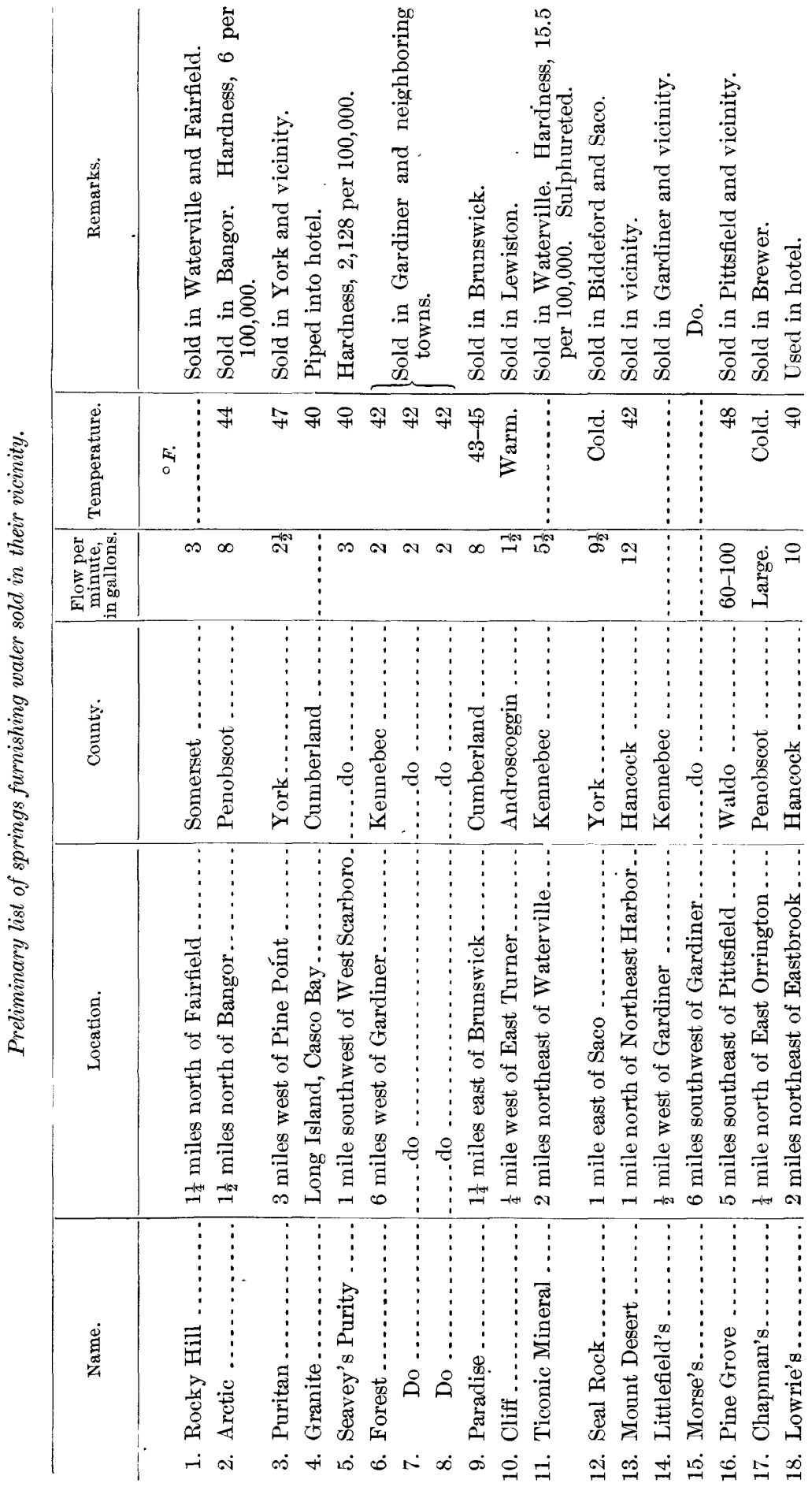



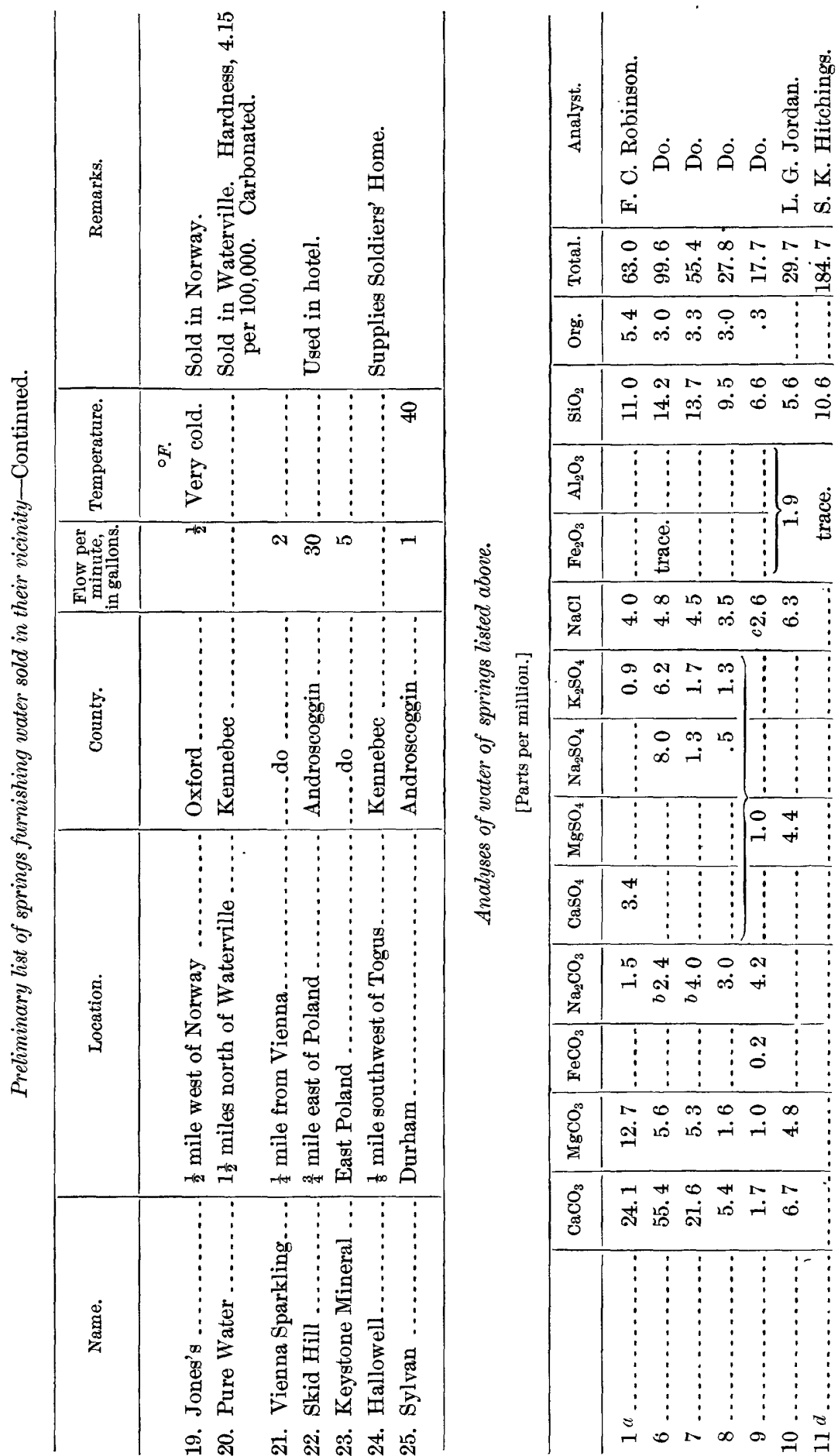


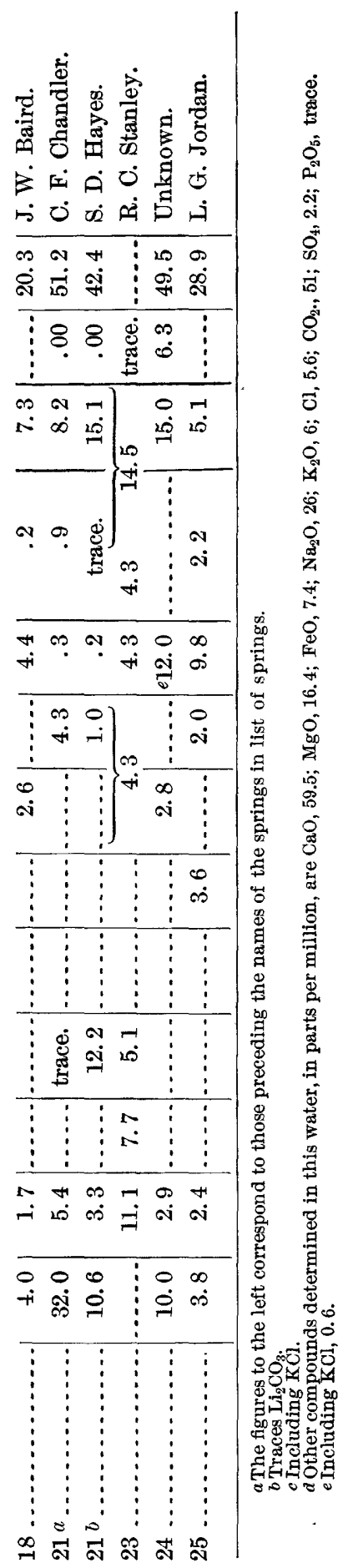


54 UNDERGROUND WATERS, EASTERN UNITED STATES. [NO. 114.

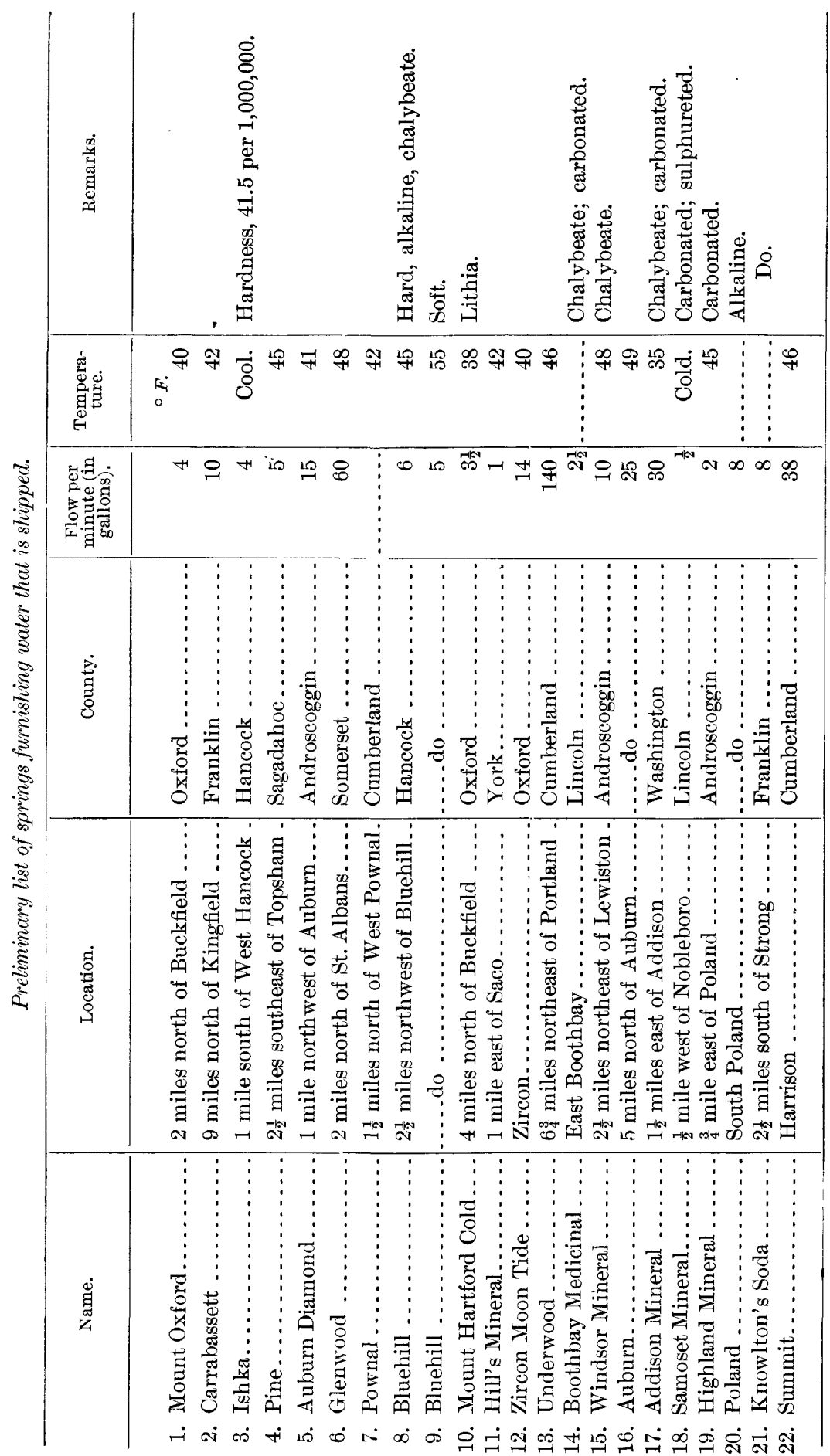




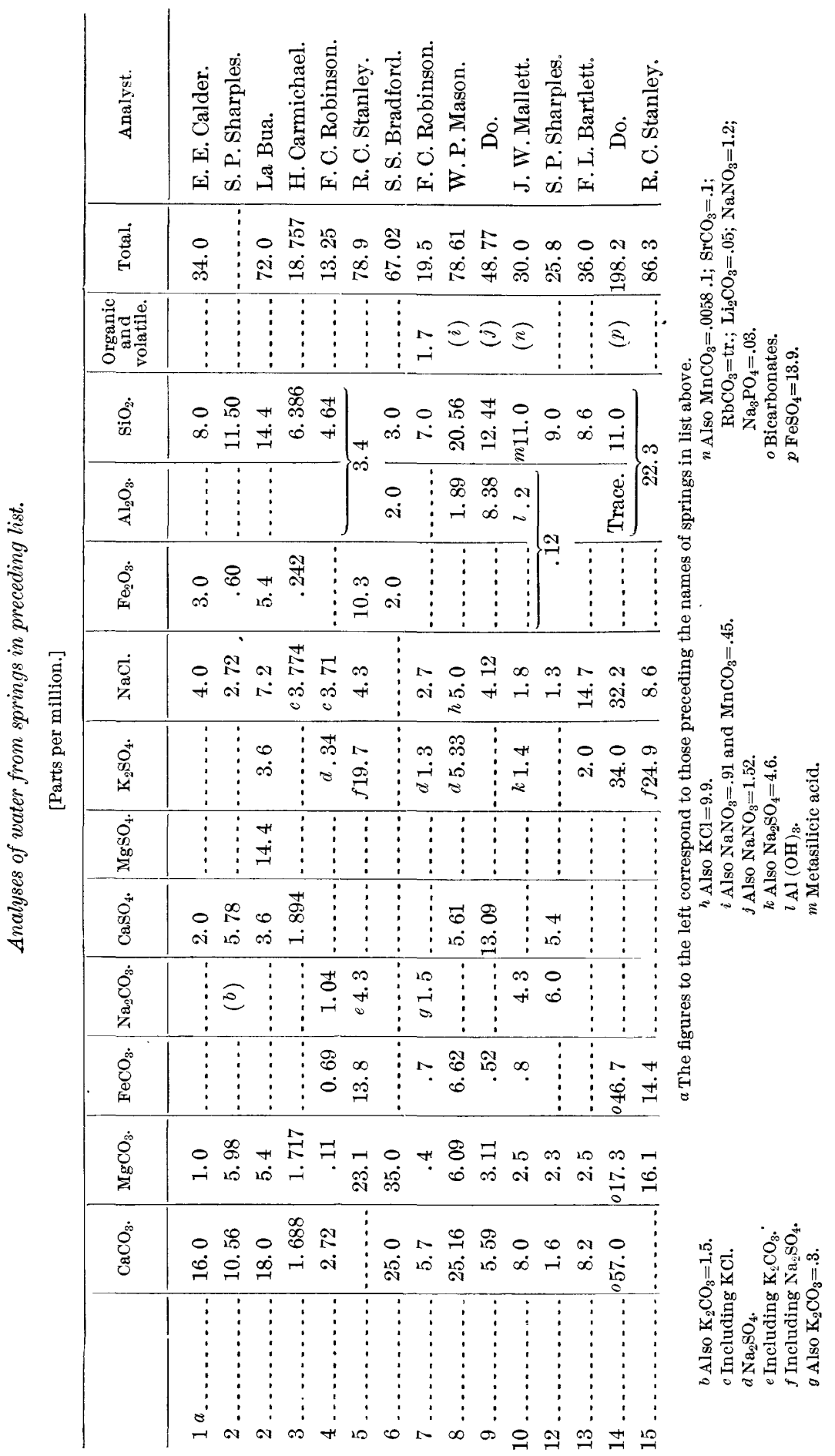




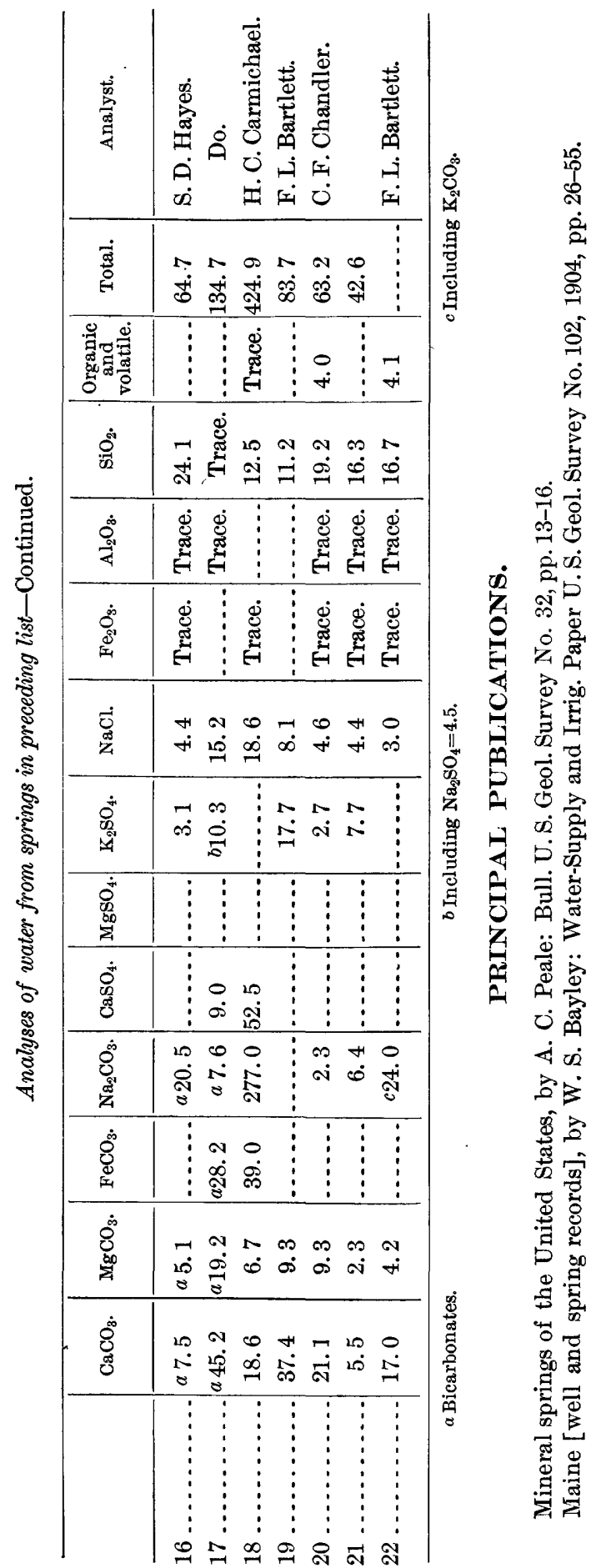




\title{
NEW HAMPSHIRE. ${ }^{a}$
}

\author{
By M. L. Fuller.
}

\section{TOPOGRAPHY.}

Taken as a whole New Hampshire is more rugged than any other New England State. Although the mountains are lacking in the definite trend which characterizes the Green Mountain and Berkshire Hill ranges, they comprise, nevertheless, the highest and most rugged peaks of the eastern section of the country north of North Carolina: The highest land is in the western and northern parts of the State, culminating in the White Mountains of the north-central portion, where Mount Washington and several other peaks reach elevations of 5,000 to 6,000 feet or over. The lowest area within the State is in the southeastern portion, where much of the land is less than 500 feet above sea level, considerable tracts lie between 500 and 1,000 feet, and a few hills and ridges above 1,000 feet.

In general the hills and mountains present smooth and rounded outlines, while the valleys are generally wide, with gentle or moderate slopes. In addition to the rock hills, there are, in the southern third of the State, a large number of smooth, lenticular hills, 100 feet or more in elevation above their base, composed of deposits formed by the glaciers when they occupied the region. They are known as drumlins.

\section{GEOLOGY.}

Over the greater part of the State the rocks are of the crystalline type, and include granites, gneisses, etc., but along the western border, . and also along a broken belt extending from the southwestern portion of the State northeastward into Maine, in the vicinity of Rochester, there are extensive outerops of slates, quartzites, schists, etc., with occasional small areas of limestone. The rocks of all types are generally characterized either by bedding or lamination planes, and are frequently much broken by joints.

Like other New England States, New Hampshire is covered with surface deposits of unconsolidated material laid down by the ice sheet or its associated drainage ways. This surface material or drift is not

$a$ The portions of the present descriptions relating to wells and springs are based on data collected by Mr. J. M. Boutwell. 
of uniform distribution, being in general of much greater thickness in the southern portion of the State than in the northern. Neither is the drift of uniform thickness in the same general region, the crests and sides of the mountains and many of the higher hills being thinly coated with or even nearly free from glacial materials. In the valleys and on the lowlands, however, the drift deposits reach a considerable thickness and afford the most important source of water in the State.

Of the types of drift the stratified deposits along the present stream channels are the most important. The sands and gravels along the Connecticut, Merrimac, Pemigewasset, Ashuelot, Contoocook, Saco, and Great Ossipee rivers are of considerable importance. Many small areas and a few large ones are covered by deposits laid down in glacial lakes at a time when the retreating ice margin blocked the northwardflowing streams. Extensive stratified deposits also occur along the Atlantic coast in the southeastern portion of the State. Outside of the areas of stratified materials of the river bottoms, glacial lake basins, and along the coast, the surface is generally covered with a bowlder clay, or hard pan, known as till. In general it is very thin, but becomes of considerable thickness in the lenticular hills, known as drumlins, in the southern third of the State.

\section{UNDERGROUND WATERS.}

WELLS.

The wells may be grouped into two classes: (1) Those in the drift and (2) those entering the rock. Of the wells in the drift, those in the compact and more or less clayey till or hard pan yield the least satisfactory supplies both as regards quantity and quality. In the stratified drift, especially in the sands and gravels of the valleys and basins mentioned above, the supplies are generally of good quality and ample in volume. In the more densely populated portions of the State, especially near the coast, the shallow drift waters are sometimes liable to pollution, but satisfactory supplies can usually be obtained at almost any point where the stratified drift occurs.

Wells are in general drilled into the rock only when satisfactory supplies can not be obtained from the drift. The rocks over a large part of the area are crystalline and dense and do not present ideal conditions for water storage, so that the value of a rock well must always be in doubt until it is completed. As already pointed out, the crystalline rocks are generally marked by lamination planes and are cut by joints, while the slates, quartzites, limestones, and other stratified rocks are characterized likewise by joints and also in many instances by rather definite bedding planes. The general effect of all of these features is to allow the water to penetrate into the interior of the rock, and most deep rock wells obtain moderate supplies, but irregularities 
in the occurrence of joints and other planes render the results of drilling very uncertain.

Many wells from 200 to 1,300 feet deep have been drilled in the State, nearly every county being represented. The majority of these have found water, although a few of the deeper wells have been failures. The supplies in some of these wells are so great as to warrant the installation of steam pumps for raising the water. The deep wells are used mainly in the various manufacturing industries and by the larger hotels.

The waters of the drift are generally soft and relatively free from mineral matter, but those obtained by the deeper rock wells are frequently hard and charged with mineral matter, especially iron.

\section{SPRINGS.}

As in all rugged regions, springs abound in the hilly portions of New Hampshire. Over a large portion of the western and northern part of the State there is hardly a farm that is without one or more available springs. In these regions springs are the leading source of domestic supplies, and at a number of places, as at Dover, Gorham, North Stafford, Nashua, Bennington, and elsewhere, springs constitute a principal or partial source of public supply. Spring waters are also frequently used in dairy and other similar industries at many points throughout the State.

Besides the uses outlined above many of the spring waters of New Hampshire are placed on the market for medicinal or table use. In 1902, eight springs reported sales amounting to 629,500 gallons, with a value of $\$ 185,995,{ }^{a}$ viz:

Amherst Mineral Spring, Amherst, Hillsboro County.

Granite State Spring, Plaistow, Rockingham County.

Hale Spring, Plaistow, Rockingham County.

Lafayette Spring, West Derry, Rockingham County.

Londonderry Lithia Spring, Londonderry, Rockingham County.

Mount Madison, formerly Gorham Mineral Spring, Gorham, Coos County.

Pack Monadnock Lithia Spring, Temple, Hillsboro County.

Toof's Artesian Well, Concord, Merrimac County.

In addition to the above springs there are probably many local springs which supply water for family use on a small scale in the cities. A number of resorts have also been established at springs.

\section{PRINCIPAL PUBLICATIONS.}

Mineral springs of the United States, by A. C. Peale: Bull. U. S. Geol. Survey No. 32 , pp. 17-18.

New Hampshire [well and spring records], by J. M. Boutwell: Water-Supply and Irrig. Paper U. S. Geol. Survey No. 102, 1904, pp. 56-72. 


\section{VERMONT.}

By G. H. Perkins.

\section{GENERAL CONDITIONS.}

Vermont is 157 miles long from north to south and, on the average, about 58 miles wide from east to west. The Green Mountain Range, which divides the State into nearly equal east and west portions, forms a watershed from which most of the streams flow either east into the Connecticut or west into Lake Champlain. As the mountains and foothills occupy a large portion of the State there is little level ground, the surface being mostly uneven-mountain, hill, or valley. The mean rainfall over the State is not far from 39 inches. Probably no State is more abundantly watered, for in most of the towns springs are numerous and unfailing, and these are supplemented elsewhere by wells and streams.

The unaltered stratified rocks of Vermont are found mostly in the Champlain Valley, where the Cambrian sandstone, Beekmantown sandstones and limestones, Chazy, Trenton, and sometimes Black River limestone and Utica shales form a narrow border along the western part of the State. East of these unchanged beds the rocks are largely crystalline and metamorphic, consisting of granite, gneiss, schist, and slate. The whole State is covered with glacial deposits, composed of gravels, clays, and sands.

\section{WATER SUPPLY.}

Public supplies.-Because of the abundance of springs and the consequent ease and cheapness with which a public water system can be established in many towns, such supply is often found where it would scarcely be expected. At least 65 towns and villages have a more or less complete public supply. Some of these are owned by the towns, many by corporations or individuals. In a number of towns there are several systems; for example, Barre has at present a system owned by the city, which supplies 1,200 families, and at least 5 smaller supplies, which are used by from 6 to 250 families each. Montpelier is still more lavishly provided, there being the city supply, which furnishes by far the greater number of the residents, and, in addition, more than twelve other sources which supply from 2 to 50 or more 
families. In 1898 a State laboratory of hygiene was established, and as water used for drinking can, under certain regulations, be analyzed here free of charge, most of the water used in the larger towns is frequently examined chemically. In the following table are given the sources of supply of most of the important cities and towns of the State:

Sources of water supp y of Vermont towns.

\begin{tabular}{|c|c|c|c|}
\hline Oounty. & Town. & Source of supply. & Ownership. \\
\hline Addison. & Middlebury & Springs... & Town. \\
\hline Do . & Vergennes!.. & Otter Creek.... & City. \\
\hline Bennington. & Arlington & Spring $\ldots \ldots \ldots$ & $\begin{array}{l}\text { Arlington Water Com- } \\
\text { pany. }\end{array}$ \\
\hline Do... & Manchester. & $\left\{\begin{array}{l}\text { Equinox Springs ...... } \\
\text { S. M. Orvis's springs.. }\end{array}\right.$ & Town. \\
\hline Caledonia & East Barnet. & Springs......... & Town water company. \\
\hline Essex & Island Pond & $\ldots$. do ......... & Island Pond Water \\
\hline Do . & Lunenburg . & Three large springs... & \\
\hline Franklin & Richford ... & Springs................ & Town. \\
\hline Do . & St. Albans... & $\begin{array}{l}\text { Reservoir (4 miles } \\
\text { from town }) .\end{array}$ & Do. \\
\hline Lamoille & Hydepark ... & Springs.................. & Private. \\
\hline Do. & Jeffersonville & . ....do ........ & Town. \\
\hline Do. & Johnson... & $\ldots$. . do ...... & Waterman \& Welch. \\
\hline Do.. & .....do ...... & $\ldots$......... & $\begin{array}{l}\text { Water company (J. A. } \\
\text { Pearl, agent). }\end{array}$ \\
\hline Do . & Stowe... & .....do .. & C. E. and F. O. Burt. \\
\hline Orange . & Bradford .... & A series of springs.... & Town. \\
\hline Do . . & North Thetford .... & Springs.......... & $\begin{array}{l}\text { Union and North Thet- } \\
\text { ford water compa- } \\
\text { nies. }\end{array}$ \\
\hline Do. & .....do.. & $\begin{array}{l}\text { Union and North } \\
\text { Thetford water com- } \\
\text { panies. }\end{array}$ & Independent farmers. \\
\hline Orleans. & Derbyline - & Springs..... & Tọwn. \\
\hline Do... & Glover ... & .....do ........ & Private. \\
\hline Do ....... & North Troy & .... do . . . . . . . & Two companies. \\
\hline Rutland & Brandon & $\begin{array}{l}\text { Hitchcock Pond (6 } \\
\text { miles north). }\end{array}$ & Town. \\
\hline Do - & Center Rutland & Springs......... & Do. \\
\hline Do . & Danby & ....do . ....... & Do. \\
\hline Do & Pittsford ... & Large spring......... & Do. \\
\hline Do... & Poultney .... & $\begin{array}{l}\text { Crystal Lake, Hamp- } \\
\text { ton, N. Y. }\end{array}$ & Do. \\
\hline Do .. & Proctor. & Springs ............... & Do. \\
\hline Do ...... & Rutland ...... & Mendon brooks ...... & Do. \\
\hline
\end{tabular}


Sources of water supply of Vermont touns-Continued.

\begin{tabular}{|c|c|c|c|}
\hline County. & Town. & Source of supply. & Ownership. \\
\hline Washington .. & Barre - & Several companies. & Water company. \\
\hline Do... & .....do .. & Springs ........... & Harvey Hersey. \\
\hline Do.. & .....do & Brooks... & Private and city. \\
\hline Do.. & .....do & Spring ........ & $\begin{array}{l}\text { Barre Spring Com } \\
\text { pany. }\end{array}$ \\
\hline Do .. & Marshfield. & Springs... & $\begin{array}{l}\text { BatchelderWaterCom- } \\
\text { pany. }\end{array}$ \\
\hline Do... & Middlesex . . & .... do .......... & Private owners. \\
\hline Do . . & Montpelier . & Berlin ponds (two) ... & City. \\
\hline Do.. & Northfield . . & Two public systems. & Private. \\
\hline Do... & Plainfield... & Springs.......... & Village. \\
\hline Do.. & Roxbury ... & .....do ...... & $\begin{array}{l}\text { J. W. Howe and G. A. } \\
\text { Tilden. }\end{array}$ \\
\hline Do . & Waterbury - & $\begin{array}{l}\text { Brooks and springs } \\
\text { collected. }\end{array}$ & Town. \\
\hline Do... & Waterbury Center. . & Springs........ & Hopkins \& Company. \\
\hline Windham & Bellows Falls. & Minard's pond & Town. \\
\hline Do... & Jamaica - & Fifteen springs... & Do. \\
\hline Windsor... & Chester .. & Stream ..... & $\begin{array}{l}\text { Chester Water Com- } \\
\text { pany. }\end{array}$ \\
\hline Do & Hartford ... & Springs.. & A. I. Peace. \\
\hline Do .. & Ludlow ... & ..... do ... & Town. \\
\hline Do .. & Norwich.... & ..... do ... & Do. \\
\hline Do ... & Rochester .... & .... do ... & Do. \\
\hline Do - & Springfield .... & .....do . . & Do. \\
\hline Do ... & $\begin{array}{l}\text { White River Junc- } \\
\text { tion. }\end{array}$ & ..... do .... & Do. \\
\hline Do... & Wilder... & Three springs .. & OlcottWaterCompany. \\
\hline Do........ & Windsor... & Springs ......... & Town. \\
\hline
\end{tabular}

Common springs.-As has been indicated, springs are abundant over a large part of the State. Of the 248 towns reporting, not less than 190 are said to be wholly or in large part supplieu from springs. Many of these springs are large and constant in flow and temperature, the latter being often as low as $38^{\circ} \mathrm{F}$., even in midsummer, and many show throughout the year a temperature varying but little from $45^{\circ} \mathrm{F}$.

As there is little or no soluble matter in the rocks in most parts of the State, the spring water is usually pure and soft.

The abundance of springs is shown in the reports from single and not large farms, that within their limits there are 20,30 , or even 40 active springs. The water supply of most towns having a public water system is taken either from one large spring or from several 
which have been connected. Analyses of many of these springs could be given. Nearly all of them, however, simply show pure water with no organic and very little solid matter, and as Vermont is for the most part not thickly settled, there are few or no sources of contamination. As an example of what may be regarded as an average sample of Vermont spring water, the following is given. The sample was taken from a tap located at some distance from the reservoir supplied by springs. It is not the purest nor the worst.

Analysis of water from Johnson, Vt.

\begin{tabular}{|c|c|c|c|}
\hline & $\begin{array}{l}\text { Parts per } \\
\text { million. }\end{array}$ & & $\begin{array}{l}\text { Parts per } \\
\text { million. }\end{array}$ \\
\hline Total solids. . & 40.4 & Nitrogen as nitrates ... & .100 \\
\hline Loss on ignition ........ & 3.2 & Nitrogen as nitrites. . . . . & None. \\
\hline Fixed solids . . . . . . . . . . & 37.2 & Hardness... & 3.1 \\
\hline Free ammonia........... & .018 & Turbidity . . & None. \\
\hline Albuminoid ammonia........ & .07 & Sediment... & None. \\
\hline Chlorine.............. & .4 & Color ....... & None. \\
\hline
\end{tabular}

Mineral springs. - Mineral springs are found, though not in large number, in different parts of the State. Most commonly they are more or less sulphurous, but alkaline carbonated springs also occur. The chief resorts on account of the water are Alburg Springs, Highgate, Sheldon, Clarendon, Middleton, and Brunswick. The springs at South Hero, Chelsea, Concord, Wolcott, Newbury, and Warren are all of some repute. The Equinox Spring, at Manchester, is not mineral, but is simply a very fine spring of pure water. The water of some of the deep wells is so strongly magnesian as to properly come under the class of mineral waters.

The springs reporting shipments of water in $1902^{a}$ are as follows:

Brunswick Mineral Spring, Brunswick, Essex County.

Clarendon Springs, Clarendon Springs, Rutland County.

Equinox Spring, Manchester, Bennington County.

Middletown Springs, Middletown Springs, Rutland County.

Missisquoi Mineral Springs, Sheldon, Franklin County.

Newfane or Vermont Mineral Spring, Putney, Windham County.

The amount shipped is stated as 89,100 gallons, with a value of $\$ 22,760$.

a Peale, A. C., Mineral Resources U. S. for 1902, U. S. Geol. Survey, 1904, p. 996. 
As examples of these mineral waters the following analyses are given: Analyses of Vermont spring waters.

\begin{tabular}{|c|c|c|c|}
\hline Clarendon Spring. & $\left|\begin{array}{c}\text { Parts per } \\
\text { million. }\end{array}\right|$ & Missisquoi Spring. & $\begin{array}{l}\text { Parts per } \\
\text { million. }\end{array}$ \\
\hline Sodium chloride.. & 2.5 & Free carbonic acid . & 45.49 \\
\hline Potassium sulphate...... & 2.0 & Sodium chloride ..... & .38 \\
\hline Calcium sulphate ..... & .8 & Calcium chloride.... & 2.12 \\
\hline Calcium bicarbonate... & 182.2 & Magnesium chloride. & .60 \\
\hline Magnesium bicarbonate. . & 36.7 & Sodium sulphate .... & 6.52 \\
\hline Magnesium chloride . . . . . & 1.1 & Calcium sulphate...... & 12.09 \\
\hline Iron bicarbonate.. & 1.8 & Aluminium sulphate . & 2.70 \\
\hline Silica ...... & 11. 2 & Magnesium sulphate.. & 5.51 \\
\hline \multirow[t]{8}{*}{ Alumina ........................ } & .8 & Sodium phosphate ..... & .08 \\
\hline & & Sodium bicarbonate .. & 126. 62 \\
\hline & & Magnesium bicarbonate.. & 72.19 \\
\hline & & Manganous bicarbonate & 1.40 \\
\hline & & Ferrous bicarbonate.. & 3.03 \\
\hline & & Silica...... & 12.25 \\
\hline & & Crenic and apocrenic acid . & Trace. \\
\hline & & Titanic acid . & Trace. \\
\hline
\end{tabular}

Ordinary wells.-Wells of any sort are less common than they would be if springs did not afford a more convenient and better source of water. Underground water is everywhere and wells can be successfully dug in all parts of the State. Most of the wells thus far dug are not deep, ranging from 10 to 30 feet, and are usually wholly in the drift or other glacial deposits. Occasionally a well is carried down into the underlying rock, but not often.

The water of wells is usually reported as hard and almost always the amount of solids in well water is much greater than in spring water. In some parts of Vermont, as on Grand Isle, it has been found better to dig very large, though shallow wells. Some of these are 16 feet in diameter and 12 to 15 feet deep. In this way more water is procured than would be obtained by making a small well and going deeper.

Deep and artesian wells.-Wells of this class are found most commonly in the Champlain Valley and in the stratified rocks. The water is very often strongly impregnated with alkaline salts, especially of magnesia and lime, and is therefore very hard. Reports have been received from about 100 wells which are over 50 feet deep. This number, however, does not include nearly all there are in the State. The deepest well in the State is one which was bored for experimental purposes rather than water by Dr. W. S. Webb. It is 1,400 feet deep and gives no water, though only 300 feet from the lake shore. A well sunk not far from the shore of the lake by the Burlington Rendering 
Company to a depth of 490 feet found no water. In both cases water had to be supplied from outside for the drilling.

Only a few of these wells flow, but in a few the water rises from 4 to 18 feet above the mouth of the well. In or near Burlington there are 16 wells bored to depths of from 130 to 496 feet. At least 5 of these are so strongly impregnated with lime and magnesia salts that they can not well be used for steam, since the precipitation of these salts fills the pipes. The water in these wells is clear and cold and is much liked for drinking. It has been found very beneficial in some cases of dyspepsia.

The character of the beds passed through by these wells was much the same, but the thickness of each bed varied greatly; that is, the first beds were glacial and the last were Cambrian or Lower Beekmantown, but in one well the glacial beds are only 20 feet thick, while in another they are over 200 . In the slate region, which is Cambrian, there are more deep wells than in any other part of the State. Mr. J. P. Hoadley, who has bored more wells than anyone else in the State, tells me that he has bored over 50 in the town of Poultney alone. Probably no other town has so large a number. As has been noticed, most of the deep wells are near

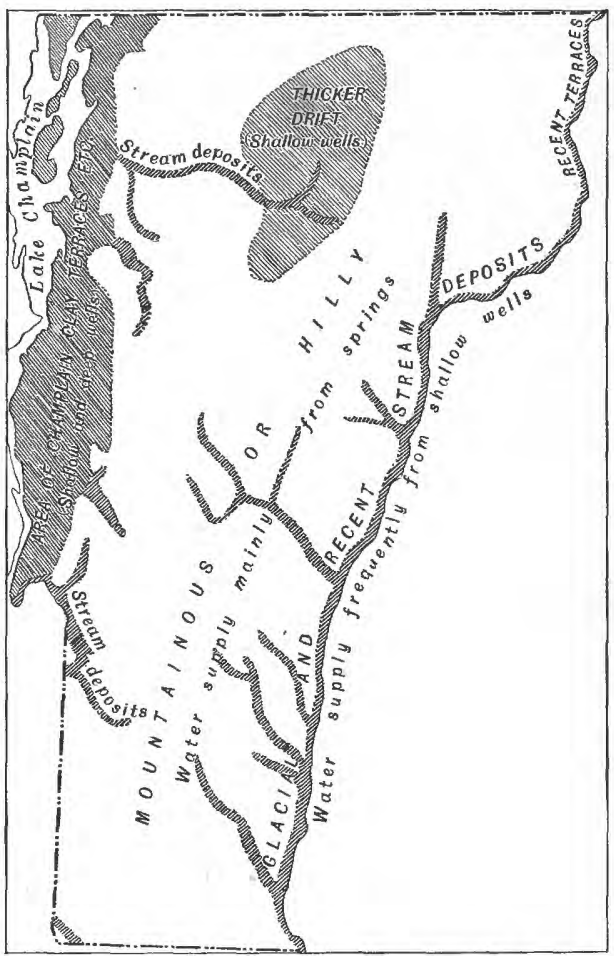

FIG. 16.-Water-bearing drift deposits of Vermont. the western border of the State, in the towns bordering Lake Champlain. The usual cost of boring deep wells in this State is from $\$ 1$ to $\$ 5$ per foot.

Lakes and ponds. - Naturally many of those who live near Lake Champlain take water from it by windmill or, more rarely, by steam pump. The only town that takes its supply from the lake is Burlington, the largest place in the State. Here the water is pumped by steam to two large reservoirs, nearly 400 feet above the lake, from which it goes by gravity over the city.

IRR $114-05-5$ 
An average analysis of the water of Lake Champlain taken from faucet is as follows:

Analysis of water of Lake Champlain.

\begin{tabular}{|c|c|c|c|}
\hline & $\begin{array}{c}\text { Parts per } \\
\text { million. }\end{array}$ & & $\begin{array}{l}\text { Parts per } \\
\text { million. }\end{array}$ \\
\hline Total solids ........ & 74.1 & Nitrates & 0.128 \\
\hline Loss on ignition - & 18.0 & Nitrites... & .00 \\
\hline Fixed solids..... & 56.1 & Sediment . & (a) \\
\hline Free ammonia........... & .035 & Turbidity.......... & $(a)$ \\
\hline Albuminoid ammonia........ & .143 & Hardness $\ldots \ldots \ldots$ & 4.3 \\
\hline Chlorine. & .68 & & \\
\hline
\end{tabular}

a Very slight.

A few towns, as, for example, Brandon and Bellows Falls, get water from small lakes or ponds. Some of these ponds are directly fed by springs and are therefore very satisfactory as a source of supply.

Streams.-A few towns-Vergennes, Wells River, and some othersget water from adjacent streams. There seems to be more danger of contamination in this case, and the supply is therefore less satisfactory.

Cisterns.- - Cisterns are not much used in this State, but there are some places in which the only other supply is from wells which give hard water, and in these places cistern water is used for drinking and laundry. The whole number of towns reporting cisterns in use is very small.

\section{SUMMARY.}

It will be seen from the foregoing statements that the questions which the necessity for wholesome and abundant water for domestic purposes raise in many parts of the country are not important in Vermont. Everywhere, except in a few places, water is abundant in quantity and excellent in quality. Many towns allow a large quantity of cool, clear, pure spring water to run to waste because there is no use for it. But the conditions under which this ample supply exists are extremely interesting and deserve extended study.

As has been noted, most of the wells and springs are located in the glacial deposits. These are often very thick. Some of the wells have gone through 200 feet or more of these deposits before reaching the underlying rock. For example, one of the four deep wells at Fort Ethan Allen was bored through 221 feet of sands and clays and then went over 150 feet into the ledge below. Few wells except those of considerable depth go into the rock. Most either stop in hardpan some distance above the rock or go just to the ledge, but rarely into it, and in those cases where, in the hope of getting more water, the 
rock has been entered, the result has not always been satisfactory, no increase in amount of water being gained. In some wells that have been carried a short distance into the rock more.and better water has been obtained, but such cases are the exception. The above applies only to shallow wells. In the deep wells often the volume of water flowing has been increased by boring deeper. This is, however, by no means always true. In the reports of several deep wells we find that as much or more water was found at 200 feet as at 300 or more.

\section{PRINCIPAL PUBLICATIONS.}

Mineral springs of the United States, by A. C. Peale: Bull. U. S. Geol. Survey No. 32 , pp. 18-21.

Vermont [well and spring records, town water supplies, and analyses], by G. H. Perkins: Water-Supply and Irrig. Paper U. S. Geol. Survey No. 102, 1904, pp. 73-93.

Water resources of the Fort Ticonderoga quadrangle, Vermont and New York, by T. Nelson Dale: Water-Supply and Irrig. Paper U. S. Geol. Survey No. 110, 1905, pp. 126-129.

Water resources of the Taconic quadrangle, New York, Massachusetts, and Vermont, by F. B. Taylor: Water-Supply and Irrig. Paper U. S. Geol. Survey No. 110, 1905, pp. $130-133$. 


\title{
MASSACHUSETTS AND RHODE ISLAND.
}

\author{
By W. O. Crosbr.
}

Since Rhode Island is half encircled by Massachusetts and presents no essentially distinctive topographic or geologic features, the two States may best be treated as a unit in a preliminary study of their underground waters.

\section{GEOLOGY.}

In a broad way Massachusetts and Rhode Island may be subdivided, according to the relief of the land, into a number of belts, each marked by its own characteristic geology and topography. The westernmost of these may be termed the Berkshire Hills. These are a series of high mountainous ridges lying in the extreme western part of the State, the rocks of which consist of strongly folded and faulted quartzites, limestones, slates, schists, etc., mostly of Paleozoic age, which by their erosion have given rise to the rugged topography characterizing the region. To the east the Berkshire Hills grade off into a less rugged and somewhat lower region of similar rocks and structure, which extends to the borders of the Connecticut Valley lowlands. These lowlands are marked in general by the presence of soft reddish Triassic sandstones and shales, with an occasional trap bed forming the ridges. They extend from the Connecticut line, where they have a width of 20 miles or more, northward to their termination, a few miles south of the New Hampshire line. East of the Connecticut Valley a belt of folded sedimentary or metamorphic rocks is first encountered, beyond which the broad crystalline belt, consisting largely of igneous rocks, but including many altered sedimentary beds, extends eastward to the coast. In the vicinity of Boston, and extending southwestward for some distance, and again in the vicinity of Narragansett Bay, and in the region to the northeast, there are considerable areas of Carboniferous sandstones, conglomerates, and slates. Cape Cod and a portion of the adjacent region consist superficially entirely of gravel, sands, ete., of glacial derivation.

Over the whole of the surface of the State is spread a mantle of drift left by the glaciers which once covered the region. This is of 
two types, a distinction being made between till, bowlder clay, or hardpan, as it is variously known, and the different forms of stratified drift, including, besides more or less distinctly stratified gravel and sand, large amounts of bedded clay or rock flour. The till is a nearly universal deposit. It attains its greatest average thickness on the upland surfaces, and its maximum thickness in the rounded hills known as drumlins and in moraines left by the ice sheet which once covered the region. In the valleys and over the lowland generally the till is to a large extent covered and concealed by the stratified drift. Except in moraines, the till is prevailingly well compacted, a true hardpan, and contains enough clay and rock flour to make it essentially impervious. Hence, save where it contains layers of gravel or sand, it must be reckoned as an unreliable water horizon as far as large volumes are concerned, but it is nevertheless the source of supply of thousands of small wells used for domestic and farm purposes. Its chief function, however, is to impound and to control or direct the movement of the water of overlying sands and gravels.

Of the stratified drift, the coarser phases, including the gravel and sand and much of the rock flour, are confined chiefly to the valleys and to the lower portions of the surface, occurring largely as overwash and delta plains, formed by glacial streams.

\section{WATER SUPPLIES.}

\section{AREAS CONSIDERED.}

The drift is by far the most important and reliable source of underground waters, and this fact makes the tracing and detailed mapping of these deposits a matter of special interest. The principal areas only may be mentioned here. These are the Berkshire Valley; the valleys of the Connecticut and its principal tributaries, where the flood plains and terraces have their chief development; the Nashua Valley, with the delta plains, etc., of glacial Lake Nashua; the Merrimac Valley, with widespread delta and overwash plains; the Boston basin, with the delta plains formed at many different levels in the series of glacial lakes once existing there; the overwash and other plains of the Blackstone Valley and the basin of Narragansett Bay; the widely-extended plains of varied origin in southeastern Massachusetts and on Cape Cod north of the inner moraine; the overwash or apron plains of the inner moraine on Cape Cod, east of Woods Hole; and the similar plains of the outer moraine, on the south sides of Marthas Vineyard and Nantucket.

The Pleistocene or glacial clays are normally composed in large part of rock flour; but in spite of this fact they must be regarded as practically impervious and of no interest as available sources of underground water, ranking even below the till in this respect. It is 
fortunate, therefore, that the glacial clays have deen deposited at relatively low levels and in the coastal areas, mainly below sea level. Water is occasionally obtained from sand or gravel underlying the clays, in which case it may have considerable head.

\section{BERKSHIRE VALLEY.}

This is an area of complexly folded and faulted sedimentary formations, mostly of early Paleozoic age, including in succession a basal Cambrian quartzite outcropping along the east side of the valley, the great crystalline Cambro-Ordovician limestone forming the floor of the valley at most points, and the metamorphic slates and schists of the Greylock and Taconic ranges. Although the quartzite is in part of a distinctly friable and permeable character, as is so well shown where it is quarried as a glass sand, and is, therefore, entitled locally to some consideration as a water horizon; the topographic relations of the limestone to the valley, regardless of other considerations, determine it as the chief bed-rock source of water. Its crystalline texture makes the limestone practically impervious and limits its water-bearing capacity to joints and fault fissures, which, however, may be appreciably widened by solution. The structure is not very favorable to artesian flows, except perhaps very locally. Though somewhat uncertain in its occurrence water is usually found in the deeper wells. It is possible that borings through the limestone at certain points might develop artesian sources in the underlying quartzite. The rock waters of the Berkshire Valley are, in general, distinguished by their hard or calcareous character, and considerations of quantity and quality combine to make them relatively unimportant.

The drift of the Berkshire region is chiefly till, and the stratified drift is mainly confined to the bottoms of the valleys, being most abundant, as a rule, where the valleys are broadest, as in the latitude of Williamstown and North Adams, at elevations below 860 feet; of Pittsfield and Richmond, mainly below 1,000 feet; and of Lenox and Lee, where existed glacial Lake Housatonic at an elevation of about 1,000 feet. South of Great Barrington the stratified drift, with a normal elevation of 700 feet, and a breadth varying from 1 to 2 miles, is continuous to the State line and beyond. The topographic relations of these deposits insures to them not only the precipitation belonging to their areas, but also a large part of the rainfall on the bordering slopes of till, and since their own contours determine a shallow water table, it follows that they must be regarded as very important and readily available reservoirs of the ground water. As in other limestone regions, the drift is more or less calcareous, as is evidenced at times by its local cementation, but rarely to such a degree as to make the water sensibly hard. 


\section{CONNECTICUT VALLEY.}

The great thickness in this valley of arenaceous strata, characterized throughout by moderate monoclinal dips, is very suggestive of artesian conditions. It does not appear, however, that this can fairly be described as an artesian basin, although in many wells the water rises nearly to the surface and occasionally flows. The best wells are in the sandstone areas. In the conglomerate or arkose areas even the deep wells sometimes fail to obtain water. The waters are always hard, especially in the shales, and it is frequently impossible to use them in boilers.

The drift of this great valley, as previously noted, is chiefly stratified, the unmodified drift or till being almost entirely restricted to the lenticular hills or drumlins, of which there are several notable groups; and the modified or stratified drift, occurring in the forms of lake beds, deltas, terraces, and flood plains, attains in places, and especially in the axis of the valley, a considerable thickness. In fact it is one of the principal storage reservoirs of New England, a large majority of the successful wells, as well, probably, as most of the springs, deriving their water from it. Over a large part of the valley, and especially on the low-lying plains as distinguished from the terraces, the water table is near the surface, and shallow wells afford an unfailing supply. The drift waters are nearly always soft.

\section{EASTERN AND WESTERN HIGHLANDS.}

The western highlands include the elevated hilly region between the Berkshire Hills and the Connecticut Valley belt, while the eastern highlands embrace the similar but less hilly region to the east of that valley.

The two regions are alike in having igneous and metamorphic bed rock, thinly covered with till on the uplands. The modified drift is confined chiefly to the valleys and is naturally most abundant in the broader valleys of the eastern highlands. This is, as usual, the chief and most available source of the ground water; and it is partly for this reason that we find the population massed upon it, the till of the uplands, as a rule, supporting only a sparse farming population. During the recession of the ice sheet the conditions favored the development of temporary glacial lakes in the valleys, especially of the eastern highlands, and at all elevations up to 1,000 feet or more; and thus may be explained bodies of modified drift of exceptional volume and depth, lying sometimes at such elevations as to make them important storage reservoirs for ground water.

Although everywhere relatively superficial, the ground water is naturally pure and soft, and a study of the topographic map shows 
relatively little obstructed drainage with consequent swampy conditions and peaty waters. On the other hand, the frequently dense village populations on the narrow and shallow valley deposits of sand and gravel present conditions especially favorable to contamination of the ground water and suggest the introduction of a public supply from similar deposits farther up the valley, or from the surface streams or ponds of the uplands. The till of the uplands, derived from metamorphic and highly quartzose formations, is doubtless of an exceptionally arenaceous and porous texture, and this feature, supplemented by occasional interbedded and superficial layers of washed material, will readily account for the water supply, often copious and excellent, of the farms.

\section{NASHUA VALLEY.}

This valley is excavated along a belt of altered slaty rocks in northeast Massachusetts. It is a relatively limited and simple tract, lying in the valley of the northward draining Nashua River, and hence presenting exceptionally favorable conditions for the development of glacial-lake phenomena, including broad and deep deltas or sand plains. These occur at various levels, but are rather limited in extent above 440 feet, and have their chief development below 370 feet. Above the lake levels stratified gravels and sands occur but scantily, and the till or hardpan, derived largely from slaty rocks, is of a relatively argillaceous and impervious character.

Bed-rock wells, whether sunk in the slaty rocks or in the bordering schist and granite, must in general be of little value, and, as on the highlands, artesian conditions do not exist except perhaps very locally, where the rocks are traversed by favorable fissures.

COASTAL LOWLANDS.

In density of population and consequent demand for water this area leads all the rest. But the concentration of the population in cities necessitates the extensive utilization of surface waters, while the ground waters have been found available chiefly for the smaller communities and private interests. This is a region of crystalline, igneous, and metamorphic rocks, with the exception of the sedimentary deposits, chiefly conglomerates and slates of Carboniferous age, of the Boston, Norfolk, and Narragansett basins. Deep rock wells are more common in this region, especially in the vicinity of Boston, than in any other part of New England. On the crystalline formations the proportion of decidedly successful wells is not large, and the result of a boring can not be predicted. In the Carboniferous slates, as proved by numerous examples in Boston, Cambridge, etc., there are very few successful wells, the water being almost invariably inferior in both quality and quantity. In the conglomerate series are 
many good wells and comparatively few failures. In no case, probably, are the rock waters yielded chiefly by interstitial flow; the good wells are those that intersect favorable systems of joints and other fissures, and in this connection it may be noted that the joint structure of the conglomerate is exceptionally distinct and open.

This is a region of abundant drift deposits. The stratified drift, including sand and gravel which is largely referable to glacial lakes or local apron plains, is widespread and, as usual, is the principal source of the ground water, supplying even some of the larger cities, such as Lowell and Providence. These deposits, as previously noted, become more continuous southward in the region of Narragansett Bay and Cape Cod Bay, and attain, no doubt, a considerable thickness. They may be regarded as a vast and practically inexhaustible reservoir of water, which, with a uniformly shallow water table, is readily available by pumping and far exceeds in quantity the demands of the present population. These statements may be repeated for the great apron plains south of the terminal moraine, on the south side of Cape Cod, and on Marthas Vineyard and Nantucket.

\section{NORMAL CHLORINE.}

The normal chlorine, or maximum proportion of chlorine (present as common salt or sodium chloride) which may exist in an uncontaminated water, usually varies inversely as the distance from the sea, the range for Massachusetts being from 2.42 parts per 100,000 at Provincetown and 2.16 parts on Nantucket to 0.06 parts in Berkshire County. The normal chlorine not only depends upon the proximity to the coast, but it is highest on the salient and most exposed parts of the coast, where the surf breaks heavily and the salt spray is wafted inland most freely. Higher amounts than those indicated are due either to peculiarities of the rocks or drift from which the water comes or to pollution by sewage. In New England it is commonly the latter which gives rise to high chlorine, and waters containing this constituent in amounts distinctly above the normal should be avoided for domestic purposes.

\section{MINERAL SPRINGS.}

\section{MASSACHUSETTS.}

Massachusetts has the distinction of possessing a larger number of springs from which waters are shipped than any other State in the country. In 1902 there were 75 such springs that reported shipments, the next largest number being 56, in New York. One reason for the large number of springs reporting sales lies in the fact that many of them are located near cities in which the demand for spring waters for table purposes is very large. The total sales in the year mentioned 
amounted to $8,475,365$ gallons, having a value of $\$ 562,973$. Following is a list of the springs reporting: ${ }^{a}$

Abbotts Spring, Methuen, Essex County.

Arctic Polar Spring, Spencer, Worcester County.

Ballardvale Lithia Spring, Andover, Essex County.

Beach Hill Spring, Stoneham, Middlesex County.

Beaver Dam Spring, Scituate, Plymouth County.

Belmont Crystal Spring, Belmont, Middlesex County.

Belmont Hill Spring, Everett, Middlesex County.

Belmont Natural Spring, Belmont, Middlesex County.

Berkshire Crystal Spring, Sheffield, Berkshire County.

Berkshire Sodium Spring, Sheffield, Berkshire County.

Bodwell Spring, Lawrence, Essex County.

Burnham Spring, Methuen, Essex County.

Chapman's Crystal Mineral Spring, Stoneham, Middlesex County.

Crystal Mineral Spring, Methune, Essex County.

Crystal Spring, Brockton, Plymouth County.

Deep Rock Spring, Lynnfield Center, Suffolk County.

Diamond Spring, Lawrence, Essex County.

El-azhar (formerly Sheep Rock) Spring, Lowell, Middlesex County.

Electric Spring, Lynn, Essex County.

Everett Crystal Spring, Everett, Middlesex County.

Farrington's.Silver Spring, Milton, Norfolk County.

Fulton Natural Spring, Medford, Middlesex County.

Garfield Spring, Weymouth, Norfolk County.

Geddes Mineral Spring, Marlboro, Middlesex County.

Goulding Spring, Whitman, Plymouth County.

Highland Spring, North Abington, Plymouth County.

Howe Spring, Millbury, Worcester County.

Howland Spring, Dartmouth, Bristol County.

Hygeia Artesian Well, Springfield, Hampden County.

Ingersoll Grove Spring, Springfield, Hampden County.

Katahdin Spring, Lexington, Middlesex County.

King Philip Spring, Mattapoisett, Plymouth County.

Läkoo Indian Crystal Spring, Lawrence, Essex County.

Lang Moore Spring, Natick, Middlesex County.

Larchmont Spring, Lexington, Middlesex County.

Leland Spring, Natic, Middlesex County.

Lexington Spring, Lexington, Middlesex County.

Iinden Mineral Spring, Linden, Middlesex County

Lovers' Leap Springs, Lynn, Essex County.

Magnolia Spring, Gloucester, Essex County.

Massasoit Spring, West Springfield, Hampden County.

Middlesex Mountain Spring, Medford, Middlesex County.

Milton Spring, Milton, Norfolk County.

Monatiquot Spring, South Braintree, Norfolk County.

Moose Hill Spring, Swampscott, Essex County.

Mount Blue Spring, Hingham Center, Plymouth County.

Mount Holyoke Lithia Spring, South Hadley, Hampshire County.

Mount Orient Spring, Pelham, Hampshire County.

Mount Pleasant Spring, Lowell, Middlesex County. 
Mount Washington Cold Spring, Chelsea, Suffolk County.

Myles Standish Spring, South Duxbury, Plymouth County.

Nashoba Minerel Spring, Westford, Middlesex County.

Nemasket Springs, Middleboro, Plymouth County.

Nobscot Mountain Spring, Framingham, Middlesex County.

Norwood Spring, Norwood, Norfolk County.

Pearl IIill Mineral Spring, Fitchburg, Worcester County.

Pepperell Mineral Spring, Pepperell, Middlesex County.

Pequot Spring, North Natic, Middlesex County.

Purity Spring, Spencer, Worcester County.

Ravenwood Spring, Gloucester, Essex County.

Robbin's Spring, Arlington Heights, Middlesex County.

Sager Spring, Danvers, Essex County.

Sand Spring, Williamstown, Berkshire Couuty.

Shawmut Spring, West Quincy, Norfolk County.

Silver Seal Spring, Woburn, Middlesex County.

Simpson Spring, South Easton, Bristol County.

Smiley Spring, Haverhill, Essex County.

Steavens's Spring, Lawrence, Essex County.

Sunnyside Spring, Franklin, Norfolk County.

Swampscott Spring, Swampscott, Essex County.

Trapelo Spring, Belmont, Middlesex County.

Undine Crystal Spring, Brighton, Suffolk County.

Valpey Spring, Woodland, Lawrence, Essex County.

Whitman Spring, Whitman, Plymouth County.

Wilbraham Mountain Spring, Wilbraham, Hampden County.

\section{RHODE ISLAND.}

The number of springs reporting sales in 1902 in this State is four. They are as follows:

Berry Spring, Pawtucket, Providence County.

Gladstone Spring, Narragansett Pier, Washington County.

Holly Mineral Spring, Woonsocket, Providence County.

Ochee Mineral and Medicinal Springs, Johnston, Providence County.

The total sales reported amount to 244,212 gallons, having a value of $\$ 26,588 .^{a}$

\section{PRINCIPAL PUBLICATIONS.}

Mineral springs of the United States, by A. C. Peale: Bull. U. S. Geol. Survey, No. 32 , pp. 21-24.

Preliminary list of deep borings in the United States, pt. 1, by N. H. Darton: WaterSupply and Irrig. Paper U. S. Geol. Survey No. 57, 1902, p. 51.

Massachusetts and Rhode Island [well and spring records], by W. O. Crosby, Laurence La Forge, and F. A. Champlin: Water-Supply and Irrig. Paper U. S. Geol. Survey No. 102, 1904, pp. 94-125.

Drilled wells of the Triassic area of the Connecticut Valley, by W. H. C. Pynchon:

Water-Supply and Irrig. Paper U. S. Geol. Survey No. 110, 1905, pp. 65-94.

Triassic rocks of the Connecticut Valley as a source of water supply, by M. L. Fuller:

Water-Supply and Irrig. Paper U. S. Geol. Survey No. 110, pp. 95-112. 


\section{CONNECTICUT.}

By H. F. Gregory.

A study of the water resources of Connecticut, based on a large number of records of wells and springs, shows that next to rainfall the nature of the rocks or deposits is the factor of greatest importance. In fact the character and availability of the water supply are directly dependent upon two geologic factors-the composition of the rock or other material, and the number of fault or joint fissures it may possess.

\section{RAINFALL.}

The annual rainfall in Connecticut is 46.89 inches. This is distributed throughout the year as follows: January, 4.28; February, 3.94; March, 4.23; April, 3.53; May, 4.03; June, 2.95; July, 4.42; August, 4.30; September, 3.34; October, 4.04; November, 4.48; December, 3.44. This is sufficient, when taken in connection with small evaporation, to form a constant supply for the streams of the State, which carry off about 40 per cent of the water that falls, and to furnish abundant ground water. So that, so far as Connecticut is concerned, the available water supply depends on the eapacity of the rock and the surface cover of land waste to hold the water.

\section{GEOLOGY AND WATER SUPPLY.}

Geologic subdivisions.-As to the characteristics of rock structure which affect underground water, Connecticut is divided into three parts: The limestone (Stockbridge dolomite) area of the upper Housatonic Valley, the Triassic sandstone area of the Connecticut Valley lowland, and the crystalline area of metamorphic rocks occupying the remainder of the State. A small area in the valley of Pomperaug River has the same characteristics as the Connecticut Valley lowland. The map, fig. 17, shows the distribution of the different classes of rock.

Limestone area.-The parts of the State underlain by the limestone are not densely populated. They contain no large cities, and the chief pursuits are dairying and mixed farming. The limestone rock varies greatly in its water-bearing capacity, and wells have usually to be sunk to a considerable depth before a supply is assured. Of nine wells selected as typical, four are over 150 feet in depth $(155,171,182,210$ 
feet, respectively), and only one is less than 50 feet. When wells are sunk this deep the supply is plentiful and does not vary with the seasons. The water is hard, containing ealcium, magnesium, and iron. The springs issuing from rock in the limestone area show. abundant, constant flow and low temperature. In one case an invariable temperature of 45 degrees is reported.

Triassic sandstone area.-The bed rock of the Connecticut Valley lowland is sandstone with interbedded basalts and intruded diabases. The sandstone varies in texture from coarse conglomerate to fine clay shales and is sufficiently porous to hold 20 to 30 per cent of its volume of water. For this area it seems to be true that the deeper the well the more abundant the water supply down to about 500 feet, and that

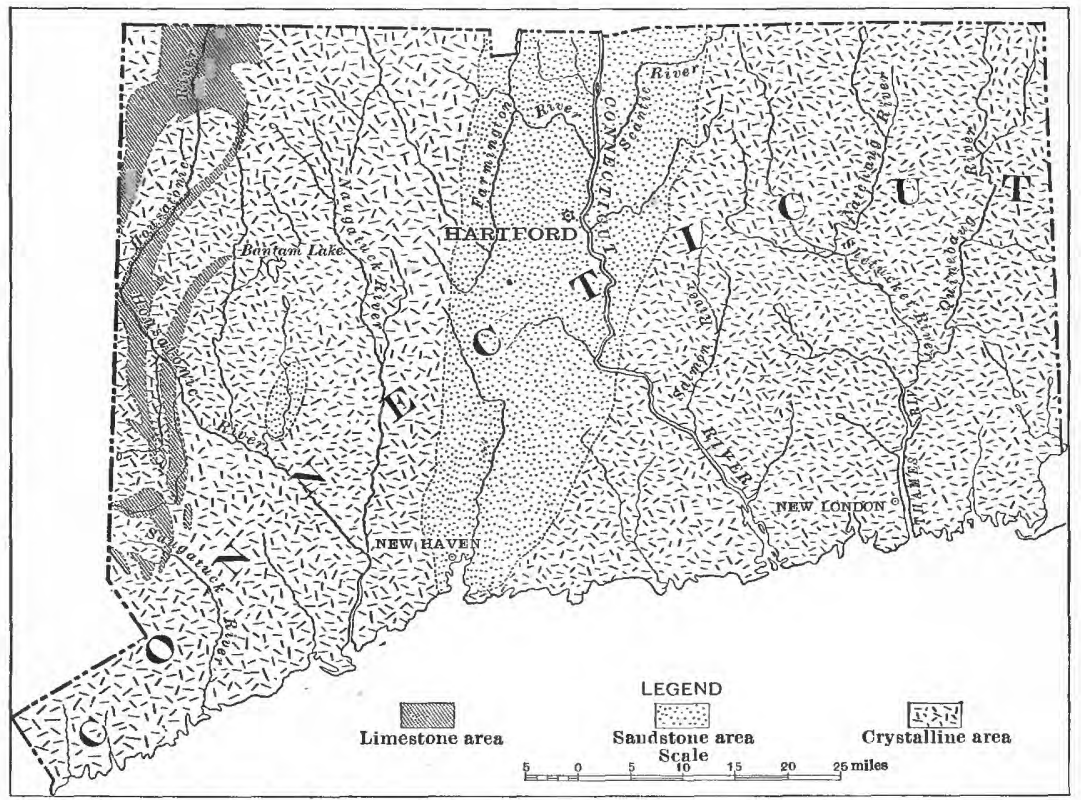

FIG. 17.-A reas of limestone, sandstone, and crystalline rock water supplies of Connecticut.

there are no distinct water-bearing beds. Wells are all deep, averaging for the whole area over 100 feet. One well at New Haven was sunk to a depth of 4,000 feet by the Winchester Arms Company in an unsuccessful effort to obtain a flowing well. The conditions for artesian water are better in the Triassic rocks than elsewhere in Connecticut, but are very unfavorable. While it is true that the sandstones contain abundant water, yet their composition, texture, and position are extremely irregular. They are not arranged in definite series, and they have been shattered by the forces which produced the faults in the valley. There is, therefore, no continuity of stratification and no arrangement of water-bearing beds favorable for artesian wel.s. The practice among well drillers in Triassic rock is to sink the well 
20 to 50 feet below the first suppıy of water, so as to have a reservoir below. Most of the deep-drilled wells afford a constant supply, but two wells show a decrease and five an increase since they were made. The cost of 60 selected wells averages $\$ 280.80$, and the cost of pumping apparatus $\$ 240.20$. More than half of the wells in sandstone supply hard water. Springs in the sandstone area that are known to issue from rock come up along deep-seated cracks and are much colder than the springs formed in glacial materials.

The Triassic area, although it constitutes one-fifth of the State, contains one-third of the population and the most productive farms (averaging $\$ 20$ per acre in annual value of crops), as well as the largest cities. It is the tobacco center, the manufacturing center, and the railroad center of the State, and is steadily increasing in population. The water supply is the best in the State, but because of the growing population it is becoming an important economic problem. At present the large cities are supplied by lakes and other surface waters, in some cases brought from considerable distances. These supplies are not inexhaustible and studies of other sources are being made. The very marked difference in character and density of population in the Connecticut Valley lowland and the crystalline highland is due partly to the conditions which control the water supply.

Crystalline area.-As shown on the map the area underlain by metamorphic crystalline rocks constitutes a large portion of the State. These rocks are remarkably variable in texture, are folded, twisted, broken, and cut by ancient intrusions and reins, and do not furnish favorable water-bearing conditions. Moreover the run-off constitutes a larger part of the rainfall than in the sandstone or limestone areas. The wells for which records are collected in the crystalline rocks (gneiss, mica-schist, etc.) average 125.8 feet in depth, and the principal water horizon lies 107 feet below the surface. Some of the deepest wells show no water below the first water horizon. Of 34 typical wells, 25 contain hard water, 2 show sulphur traces, 4 iron. The average cost of drilling these wells is $\$ 678$ and of the pumping apparatus, $\$ 162$. Some wells have been sunk in the crystalline area which have resulted in complete failure after the expenditure of thousands of dollars. The conditions governing the flow of underground water in metamorphic rocks are not well understood, and it is hoped that arrangements can be made to investigate the water resources of this area, especially along the coast line, where the summer population is increasing yearly.

Springs in the crystalline area known to issue from rock are fairly abundant and yield an unfailing supply. Nearly all of those which have been examined are located along lines of faulting and, judging from their constant low temperature, come from considerable depth.

With the exception of the valleys possessing water power, the crystalline area is given over to mixed farming, and the population is 
scattered and in many places is decreasing. The State of Connecticut has added 162,000 to its population in the last ten years, yet during that time 55 townships located on the crystallines have decreased in population. One whole county (Tolland) showed $\dot{a}$ net decrease of about 1,400 between the years 1890 and 1900 . The value of farm products on the crystalline uplands has increased somewhat during the past decade, yet it barely exceeds $\$ 10$ per acre, and the proportion of improved land to total area is less than 10 per cent.

Faults. - Connecticut is traversed by sets of fault planes running in three or four principal directions. The breaks have produced profound effects on the topography and exert a marked influence on the water resources. They control in part the direction of Connecticut rivers and are the chief cause for the many deep, cold springs of the State, and especially of the mineral springs used for table waters. The springs near South Britain, those which supply water to the village of Collinsville, and the Stafford springs are examples of those which are believed to owe their origin to deep-seated fault cracks. Springs from such deep sources form valuable water supplies and a study is being made of their distribution and character and of means for their fuller utilization.

Water supply of the drift.--The entire State of Connecticut has been overridden by the ice of the Glacial epoch, and this fact has greatly affected the water supply. The numerous lakes, ponds, swamps, and many of the smaller streams owe their position and their very existence to the continental ice sheet. Of particular value to man are the hundreds of lakes, which constitute the principal water supply for cities and villages. The soil of Connecticut also dates from the Glacial epoch, and its character as a water bearer is determined by this circumstance. The bed rock is covered nearly everywhere by one of two kinds of glacial material: (1) Till, which was deposited directly by the ice, and which is a heterogeneous, unassorted mass of, bowlders of different sizes embedded in clays of variable texture and composition; (2) stratified drift, which is made up of sands, gravels, and clays, sorted as to size and deposited in layers, and which owes its structure to the fact that it was deposited by water.

The till occupies all the highlands of the State, forming a mantle, usually but a few feet in thickness, over the crystallines and over the trap ridges of the Triassic area. Wells in till are usually shallow, rarely over 50 feet in depth, and it is the practice to sink them but a few feet below the principal water horizon. Seventeen wells are reported as being less than 10 feet in depth and yet containing an abundant supply of water. In general, the wells of the till area contain soft water, which varies in amount with the seasons. During an unusually dry summer the wells in some sections dry out entirely. The till-covered crystallines are being occupied by hotels, sanitariums, 
and country estates, and the problem of the increased water supply for these is becoming more and more important.

The springs of the till area furnish prevailingly soft water, and, like the wells, show their connection with the rainfall by their variation from year to year and from season to season. Except in extraordinary years the variation is slight, because the Connecticut rainfall is evenly distributed throughout the year. (Rainfall at New Haven: Spring, 11.67 inches; summer, 12.79; autumn, 11.67; winter, 11.84.)

Stratified drift forms the cover over a large part of the sandstone district, and also occupies the valleys in the crystallines. It varies in depth from only a few inches to over 500 feet, and because of its prevailingly loose texture forms a water reservoir of great capacity. On the New Haven sand plain and in general throughout the Connecticut Valley lowland, water maintains a permanent level 20 to 30 feet below the surface, and the practice is to sink the wells to some distance below this water horizon, so that a reserve supply is always on hand. Where large quantities of water are required for boilers, manufactories, swimming pools, etc., several wells are sunk in close proximity and connected with one pump. Yale University uses 34 such wells to supply water for the gymnasium. The wells in the stratified drift, for the most part, furnish pure water and indicate an available supply which may be used as the cities increase in size. Wells are nearly all driven, and cost on an average $\$ 348$. The pumping apparatus costs on the average $\$ 250$. Springs in stratitied drift are not numerous, and they vary in size according to the relative thickness and position of the sand and clay layers. Many are wet-weather "seeps;" others furnish sufficient supply for a farmhouse; a few, like the Pequabuck Spring, near Bristol, have sufficient water to form a brook.

Mineral springs.-Fourteen springs in the State furnish water for table use and for medicinal purposes. The Arethusa Spring, at Seymour, which is perhaps best known, marketed 38,000 gallons of water in 1902. Extreme purity is the chief characteristic of the springs located along fault lines, although in a few cases the analyses show the presence of lithium, magnesium sulphate, and other ingredjents which give them medicinal values. The pure and abundant spring water is an extremely valuable commercial asset for the State.

The springs reporting sales in $\mathbf{1 9 0 2}$ are given in the following list. The total output is reported as 307,000 gallons and the value as $\$ 194,085 .^{\alpha}$

Althea Springs, near Waterbury, New Haven County.

Arethusa Spring, Seymour, New Haven County.

Aspinock Mineral Springs, Putnam Heights, Windham County.

Cherry Hill Spring, Hamden, New Haven County.

Granite Rock Spring, Higganum, Middlesex County،

Live Oak Spring, Meriden, New Haven County.

$a$ Peale, A. C., Mineral Resources U. S. for 1902, U. S. Geol. Survey, 1904, p. 996. 
Mohican Spring, near Bridgeport, Fairfield County.

Oxford Mineral Spring, Oxford, New Haven County.

Park Spring, Willimantic, Windham County.

Puritan Spring, Norwich, New London County.

Stafford Mineral Spring, Stafford Springs, Tolland County.

Each year more land of the till-covered uplands, which has proved unprofitable for farming, is being purchased for country residences and large estates. For these purposes an abundant supply of water of unquestionable purity is indispensable.

It is of scientific interest that the Indian Rock spring water at New Milford and also the surface water at New Haven have been shown to be radio-active.

With the exception of the medicinal waters the Connecticut supply is used almost entirely for domestic and manufacturing purposes, and for these uses is uniformly good. Very rarely are wells or springs or surface supplies unfit for domestic use and only a few manufacturers report water unsuited for boilers or for washing fabrics.

Stream supplies.-The larger rivers of the State are not at present directly available as water supply because the sewage and refuse from manufacturing establishments are emptied directly into them. They thus stand as a large unimproved resource which may be developed whenever the demand for increased domestic water supply justifies the expense of installing plants for the purification of sewage.

Irrigation.-Irrigation is practiced to a small extent in Connecticut, and wherever used the results more than justify the expense. There are but few crops which have all the water necessary for their maximum yield. Hay, in particular, needs abundant water, and is one of the most valuable crops of Connecticut. There is no doubt but that the yield of most field crops could be greatly increased both in acreage and amount per acre by the use of water. The valleys of the crystalline uplands which are now sparsely settled are particularly adapted to irrigation, and it seems evident that a more intelligent use of the soil, the woodlands, and the water resources of the State could win the unimproved and abandoned lands to profitable agriculture.

\section{PRINCIPAL PUBLICATIONS.}

Mineral springs of the United States, by A. C. Peale: Bull. U. S. Geol. Survey No. 32 , pp. 25, 26.

Preliminary list of deep borings in the United States, pt. 1, by N. H. Darton: WaterSupply and Irrig. Paper U. S. Geol. Survey No. 57, 1902, p. 20.

Connecticut [well and spring records], by H. E. Gregory, F. A. Champlin, and C. L. Grant: Water-Supply and Irrig. Paper U. S. Geol. Survey No. 102, 1904, pp. $127-168$.

Drilled wells of the Triassic area of the Connecticut Valley, by W. H. C. Pynchon:

Water-Supply and Irrig. Paper U. S. Geol. Survey No. 110, 1905, pp. 65-94.

Triassic rocks of the Connecticut Valley as a source of water-supply, by M. L. Fuller:

Water-Supply and Irrig. Paper U. S. Geol. Survey No. 110, 1905, pp. 95-112.

IRR $114-05-6$ 


\section{NEW YORK.}

By F. B. Weeks.

In the State of New York, as in other regions where there is no considerable variation in the amount of rainfall or in the rate of evaporation, the occurrence and character of the underground waters are very largely determined by the topography, by the character of the soil and underlying rocks, and by the structural features of the strata.

\section{PH I SIOGRAPHY.}

The State may be divided into five distinct physiographic provinces, viz, (1) Adirondack, (2) Eastern (Taconic), (3) Catskill, (4) Allegheny Plateaus, (5) Ontario. The Adirondack province is the only one lying wholly within the State, the others forming parts of larger topographic divisions which extend beyond its limits.

1. The Adirondack province, second in size, comprises a mountainous area flanked on all sides by a lower, hilly country. It is drained by headwaters of streams flowing into St. Lawrence, Hudson, Black, and Mohawk rivers.

2. The eastern (Taconic) province in its northern part is hilly or mountainous, being formed by the Taconic ranges, which extend into Vermont and Massachusetts, while in its southern part it becomes more gently undulating. It is principally drained by short streams flowing into the Hudson.

3. The Catskill province is composed in part of folded rocks of the northern extension of the eastern Appalachian ridges, and in part of horizontal rocks, and on the west merges into the Allegheny Plateaus province. This region has been deeply dissected by streams which flow into Hudson, Delaware, and Susquehanna rivers.

4. The Allegheny Plateaus province occupies one-third of the State, comprising the area south of the Ontario province from Lake Erie to the Catskills. It contains a number of broad river valleys and is drained by streams that flow into Susquehanna, Allegheny, and Genesee rivers.

5. The Ontario province extends in a rather narrow band around Lake Ontario from the Niagara to the St. Lawrence and is drained by 
short streams, some of which form the outlets of the so-called Finger lakes.

The accompanying map (Pl. V) shows the main drainage lines in the State and from these the outlines of the several physiographic provinces may be deduced. The distribution and lithologic character of the several geologic systems represented in the State have been indicated, except the Quaternary. Those springs which are of commercial value are also noted on the map. They include all springs thus far reported whose waters are sold or used in connection with manufacturing enterprises or public water supply.

\section{GEOLOGY AND UNDERGROUND WATERS.}

The underground waters will be discussed under the several geologic divisions.

Pre-Cambrian.- The pre-Cambrian system is composed of ancient crystalline rocks and of more or less metamorphosed stratified rocks which can not readily be separated from them. Pre-Cambrian rocks form the greater part of the Adirondack region and also outcrop in the southeastern part of the State. No distinct water-bearing beds occur in these rocks, since the most of them are not stratified or have been so greatly compressed and folded that the stratification planes are no longer even approximately horizontal. The ground water descends along fracture planes and can be obtained at various depths.

In the Adirondacks there are a great number of springs, such as are common in mountainous areas. They are the sources of the many streams that drain the region. The inhabitants depend very largely upon streams and springs for domestic and stock-water supply. The few wells reported obtain their water from sands and clays overlying the hard rocks. In the southeastern part of the State the pre-Cambrian system consists of granites, gneisses, and metamorphic rocks, compressed into folds whicb have a northeast-southwest direction, and which outcrop in New York, Orange, Putnam, and Westehester counties. In Putnam and Westchester counties several springs having a flow of 100 to 300 gallons an hour, and many smaller springs are reported. The water from a few of them is bottled and sold. Records of deep wells up to 250 feet have been obtained. The deep wells are pumped by windmills or other power and furnish from 30 to 250 barrels a day. The waters of these wells are usually soft. By far the greater number of wells are dug or blasted in rock. These are from 6 to 50 feet deep, and three-fourths of them are said to fail during protracted droughts. The water is frequently reported as alkaline.

Cambrian.- The Cambrian linestones and slates extend in a long, narrow band through Washington and Rensselaer counties into Columbia. These strata have been greatly affected by folding and faulting, which, together with the considerable variation in the lithologic char- 
acter of the rocks, frequently cause a marked difference in depth to water horizons and in the character of the water within short distances. There are springs of large flow in this region, and the supply of many of them, which appears to come from Quaternary sands and clays, is probably largely derived from the underlying strata. At Cambridge and Shushan, in Washington County, springs of very large flow are reported. At other localities springs are utilized to fill ice ponds and also furnish water power for small feed and sawmills. Most of the wells in the area are less than 100 feet deep. 'Their waters, except those in the limestone lenses, are soft. In the town of Cambridge, Washington County, a well drilled to a depth of 39 feet furnishes 150 to 200 gallons an hour and may be considered an average well of the region.

The Cambrian sandstone (commonly known as the Potsdam sandstone) occurs on the northern side of the Adirondacks and also in detached areas, too small to be shown on the map, on the southeastern and southern flanks. It is usually a compact sandstone varying in color from light gray to buff and sometimes reddish-brown. No records of deep wells in these sandstones have been obtained. Dug wells 20 to 50 feet deep furnish a sufficient supply for domestic purposes. Small springs are very abundant, but none of very much economic importance are known. •

Ordovician.-The strata which are called Ordovician consist of a great thickness of limestone and shales, often intensely folded and highly metamorphosed. They form the surface rocks of the Mohawk River Valley, extending in a northwesterly direction from Albany to Lake Ontario along the southeastern, southern, and southwestern sides of the Adirondack area. They also occupy the greater part of the region east of Hudson River south of Lake Champlain, and south of Kingston they extend in a southwesterly direction beyond the New Jersey line. They also occur in a narrow strip along the St. Lawrence. Within these areas many springs of considerable economic importance, including a large number of mineral springs, come to the surface. They are particularly abundant in the valley of the Mohawk, and in a number of localities furnish water power and in others supply creameries, railroad tanks, etc. The celebrated mineral waters of Saratoga Springs and vicinity are found in fractured zones of the Trenton limestone, where they occur in a narrow belt extending for several miles in a northeast-southwest direction. The shale strata form the greater part of this system and afford the larger part of the water supply.

Massena Springs, in St. Lawrence County, and Lebanon Springs, in Columbia County, are old, well-known mineral spring resorts, the latter being the only thermal water in the State.

In some areas, as in southwestern Montgomery, in Albany, Colum- 


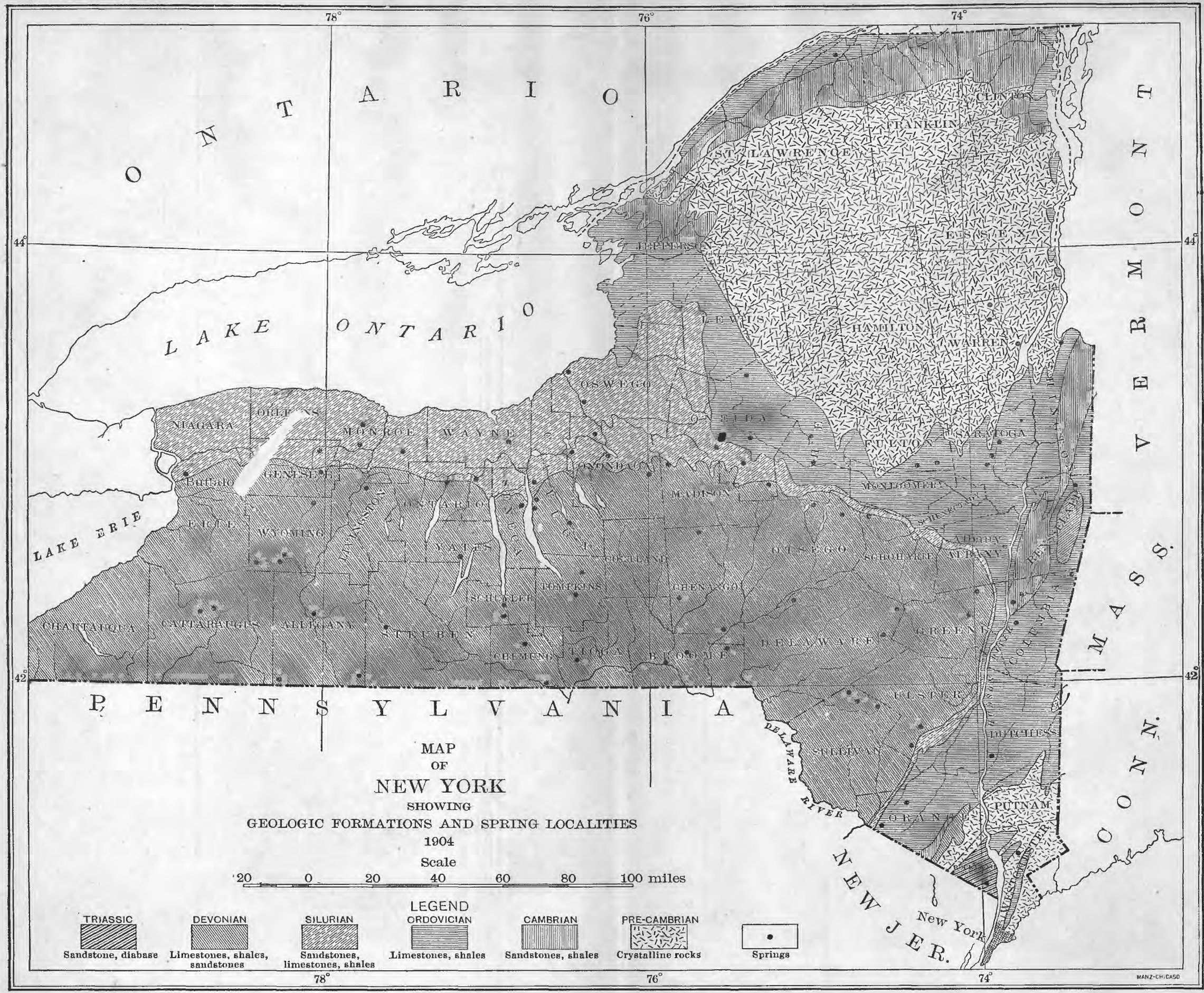

GEOLOGIC AREAS AND SPRING LOCALITIES OF NEW YORK. 
bia, and other counties, wells yield from 50 to 200 gallons per minute, the water being obtained in the shales at depths of 100 to 500 feet. In some of the wells the water is hard, in others it is soft, and in many it contains considerable gas. These artesian areas are determined by varying local conditions of structure and rock composition. Wells that require pumping are very abundant, and the depth to water in the solid rocks varies with the thickness of the glacial sands and gravels which cover a large part of the Ordovician strata. The water of such wells is usually abundant, but it is frequently impregnated with iron, sulphur, and gas, which in some instances renders it unfit for drinking.

Silurian.-The Silurian rocks outerop in a narrow band from the New Jersey line northeastward to Kingston and northward to a point opposite Albany, where the belt bends to the northwest and occupies much of the Ontario province. The sandstones that form the lower part of the system extend along the southern shore of Lake Ontario and on its eastern shore spread out over a broad area north of Oneida Lake. As the greater part of this area is covered with glacial deposits, the springs may derive their waters wholly from these beds. Several important mineral springs are found in this region, notably those of Oswego, from which water has been sold since 1870. The wells that penetrate the sandstones range in depth from 50 to 125 feet, and furnish large supplies of water, which is usually hard.

South of these sandstones is an area of limestone, in which springs of hard water are fairly abundant. No important mineral springs occur in it. In Orleans, Monroe, and Wayne counties wells drilled to depths ranging from 75 to 125 feet obtain supplies amounting in some cases to 150 gallons per hour. This limestone area narrows eastward and disappears south of Utica.

The highest rocks of this system are generally shales, and extend from Niagara River eastward in a belt parallel to the limestones and . sandstones. Nearly all the waters from these shales contain mineral matter in varying amounts, and many of them are used for medicinal purposes. The water of Oak Orchard Springs, in Genesee County, is remarkable for its content of free sulphuric acid, which is a rare constituent of mineral water. In Oneida County there are a large number of mineral springs and wells near Clinton, Franklin Springs, Kirkland, and Booneville, from which water is bottled and sold. These waters come from near the junction of the sandstones and shales. One of the deep wells in this county is at Deansboro. This is 300 feet in depth and the water rises within 20 feet of the surface and is used for cooling milk. In Niagara County near Lockport a well 115 feet deep penetrated the shales and the water flows during the winter months. Near Henrietta, Monroe County, is a flowing well 65 feet in depth, which is said to afford a large supply of water. 
The southern limit of the Silurian is marked by a narrow band of sandstone extending from Genesee County eastward, and along or near the line of contact there are many springs. Among these are mineral springs near Williamsville, Honeoye Falls, Clifton Springs, Chittenango Springs, and Sharon Springs.

Devonian.-Rocks of this system cover practically all the Allegheny Plateaus and Catskill provinces. It contains two prominent narrow limestone bands and a great thickness of shales and sandstones. The entire thickness of the series has been estimated at about 3,400 feet. The Silurian sandstone, just described, is succeeded to the south by a prominent limestone, which is followed farther south by a series of shales. Along the contact of this limestone and shale several important mineral springs occur. Prominent resorts and sanitariums are located at Avon, Richfield Springs, and Cherry Valley. Still farther south are springs at or near Penn Yan, Dryden, Watkins, Slaterville, and Spencer, their waters being derived from the upper portion of the Devonian sandstones and shales.

In the central and northern portions of the Devonian area comparatively few flowing wells have been reported. In Chautauqua, Cattaraugus, and Allegany counties most of the wells in rock, 100 to 500 feet deep, flow and furnish up to 1,000 gallons an hour. They are principally used for domestic purposes, creameries, oil-pumping machinery, and various manufacturing establishments. Some of them are mineralized and are considered beneficial in treating various diseases. In the southern tier of counties east of Allegany County the number of flowing wells decreases, but large supplies of water are obtained by pumping. An appreciable amount of iron and sulphur is found in the waters of many of the wells throughout the Devonian area.

Triassic.-The rocks of this system are reddish sandstone and diabase and outcrop in Rockland County. Water comes to the surface along the line of contact of these rocks in springs and seeps. At West Nyack and Bardonia the flows are estimated at 100 gallons an hour. At Nanuet and Orangeburg are other important springs. Fair supplies of water are obtained at Monsey, Spring Valley, and Orangeburg, at depths ranging from 40 to 180 feet. Most of the wells in the diabase or trap rock are shallow and the supply materially diminishes in dry seasons. In the sandstone the supply is more abundant and permanent and the water is usually soft.

Cretaceous. - The Cretaceous beds underlie the Quaternary drift at no great distance from the surface throughout the larger part of central and western Long Island and outcrop at a number of points along the north shore, and, more rarely, in the hills of the interior. Flowing wells of excellent water have been obtained at depths ranging from 100 to 700 feet below sea level. 
Quaternary.-The Quaternary deposits of gravel, sand, and clay are, for the most part, of glacial origin and cover the hard rocks to a great extent. Their thickness in places amounts to 300 feet or more. Water permeates these unconsolidated materials very readily, and it is probable that the amount of well and spring water obtained from these deposits equals or even exceeds that derived from all other strata in the State. Springs are very abundant and some of them have large flows, which are utilized in many ways. Where not locally contaminated they furnish water of excellent quality, which is frequently used to supply village and town waterworks. Flowing wells are very abundant, especially in the southern part of the State, and yield from 50 to 600 gallons an hour. Thousands of dug and driven wells throughout the State derive their supplies from the Quaternary beds.

The largest supplies from the Quaternary deposits are obtained from the outwash plains and other deposits of Long Island. These plains consist largely of sand or fine gravel and are saturated with water below a moderate depth. Many towns and cities, including Brooklyn, obtain the whole or part of their supplies from shallow wells or springs that issue from the sands. Springs abound along both the north and south shores, and are found to a lesser extent in the moraine in the interior. Water from several of them is placed on the market.

\section{PRODUCTION OF MINERAL WATERS.}

If it were possible to estimate the amount and value of the water supply it would certainly rank as one of the most important of nature's products. During the past twenty years statistics have been obtained to show the amount and value of mineral waters produced and sold in the United States. For the year 1902, in New York State, $6,609,176$ gallons were sold, valued at $\$ 1,299,037 .{ }^{a}$ The bottling and shipping of water for drinking purposes in large cities and towns has become a considerable industry in many favorably situated localities. It is increasing very rapidly, but no statistics of amount or value are available." 


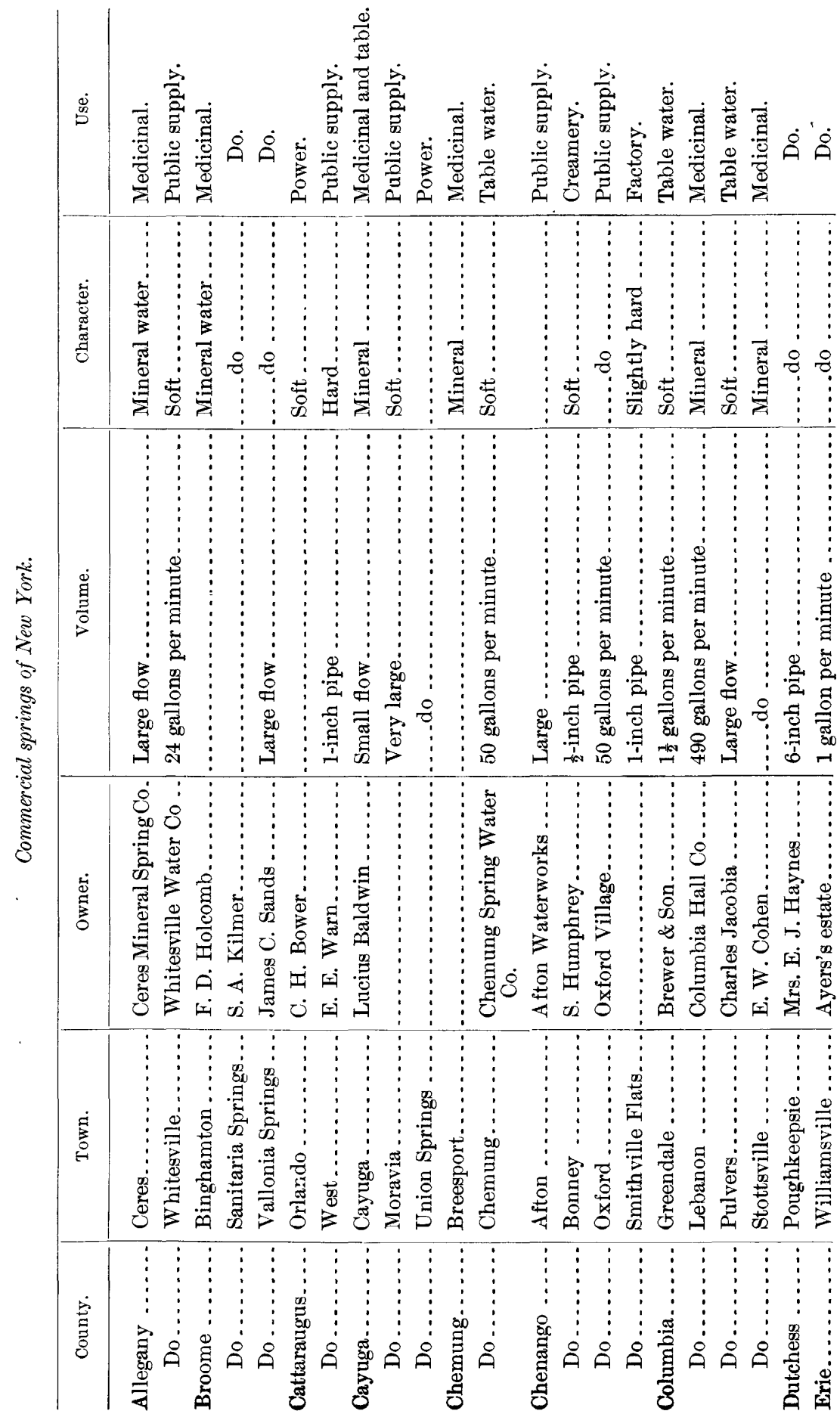




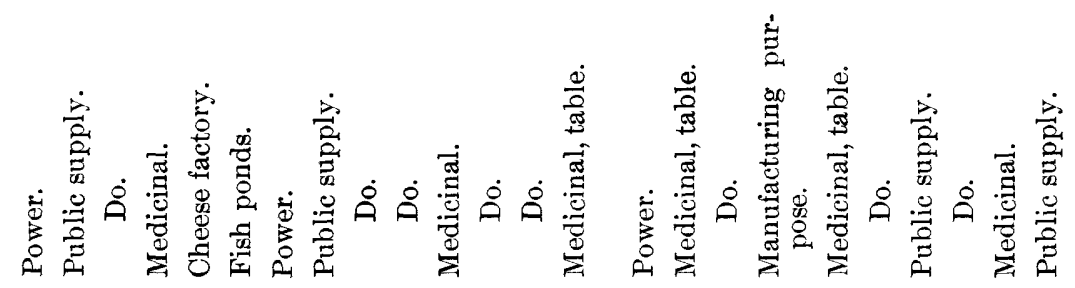

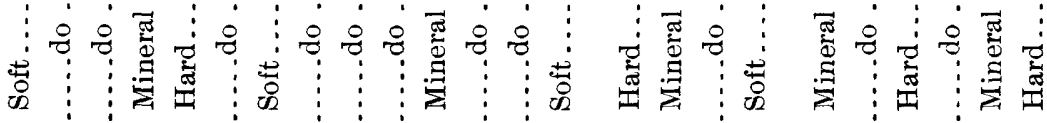

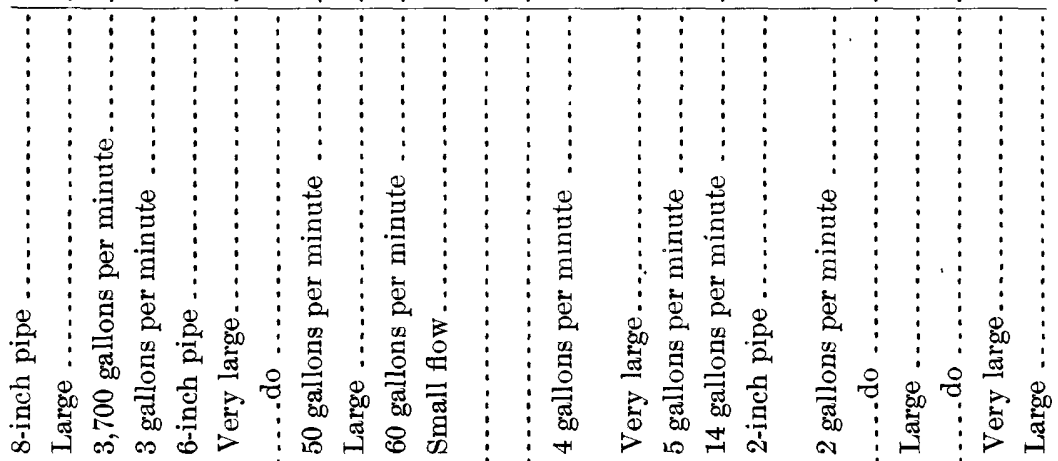

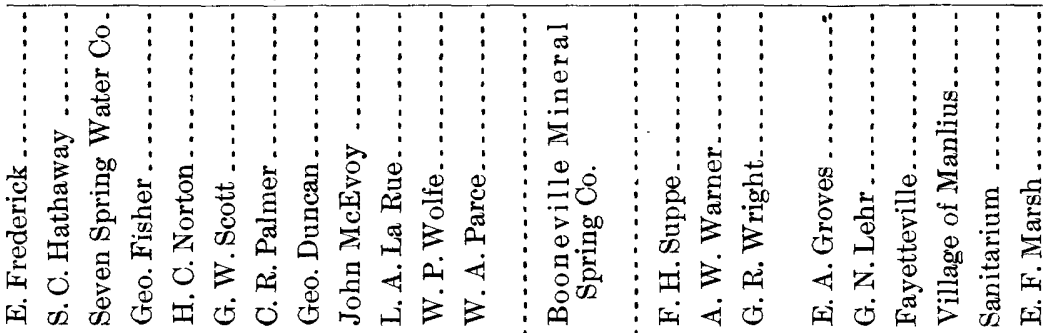

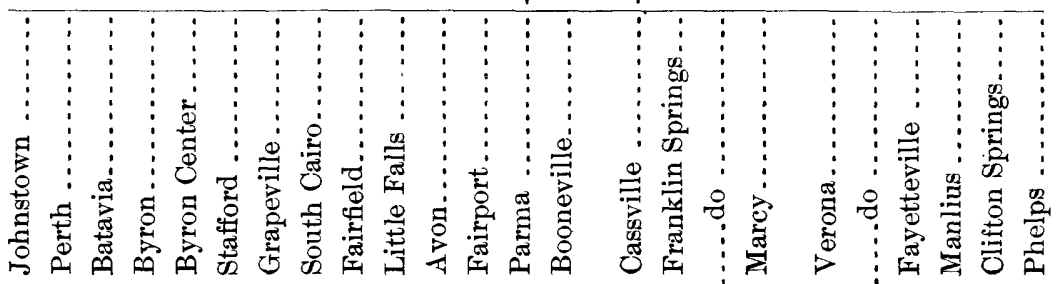

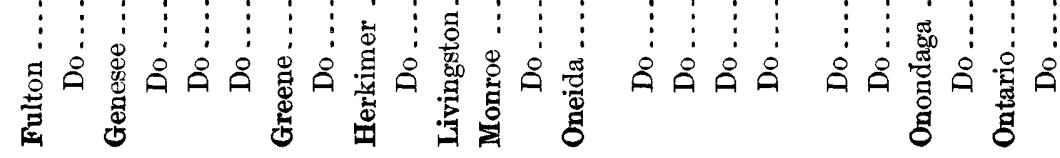


90 UNDERGROUND WATERS, EASTERN UNITED STATES. [NO. 114.

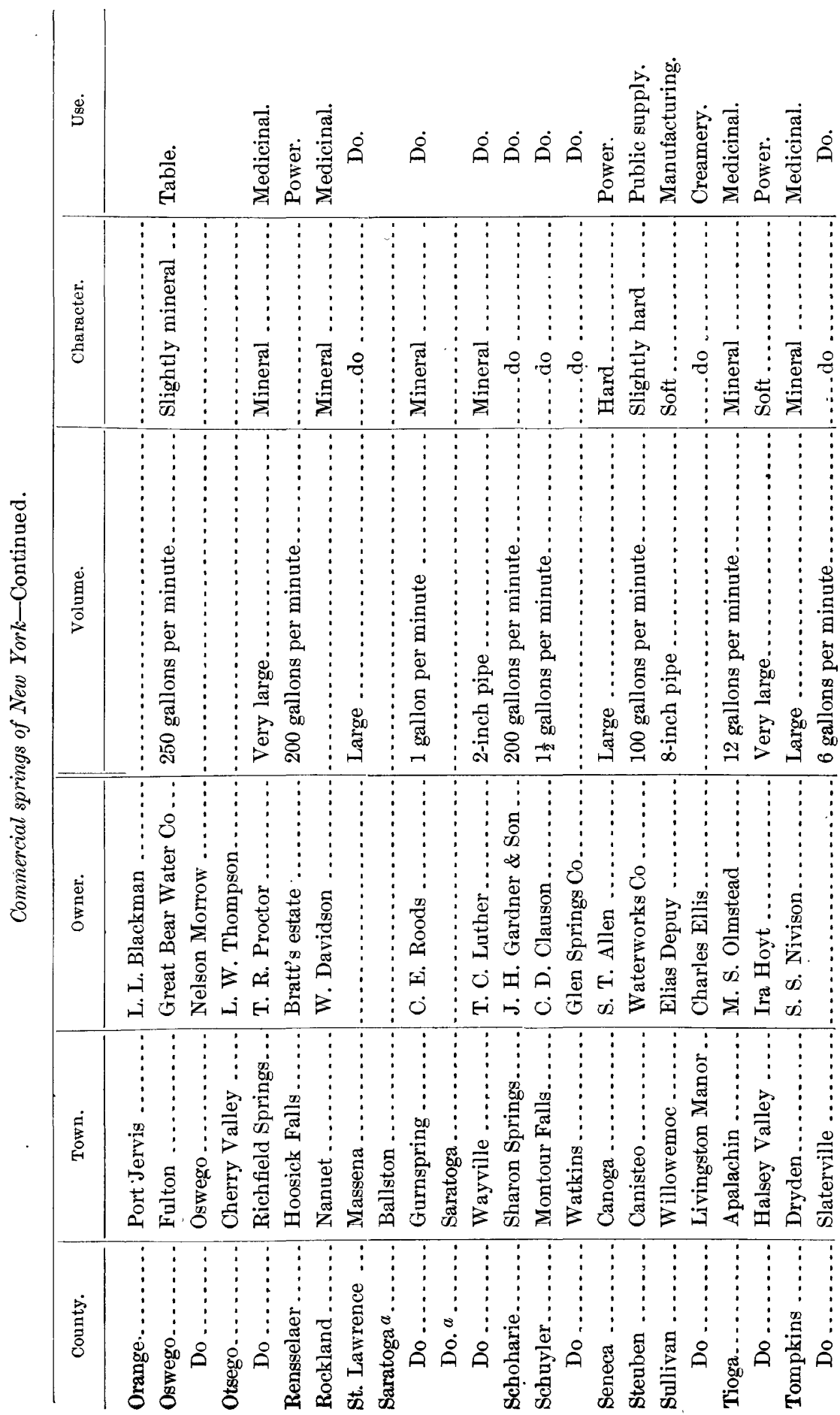




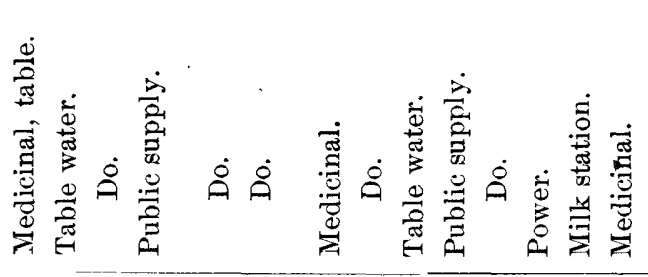

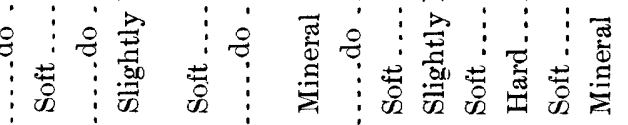

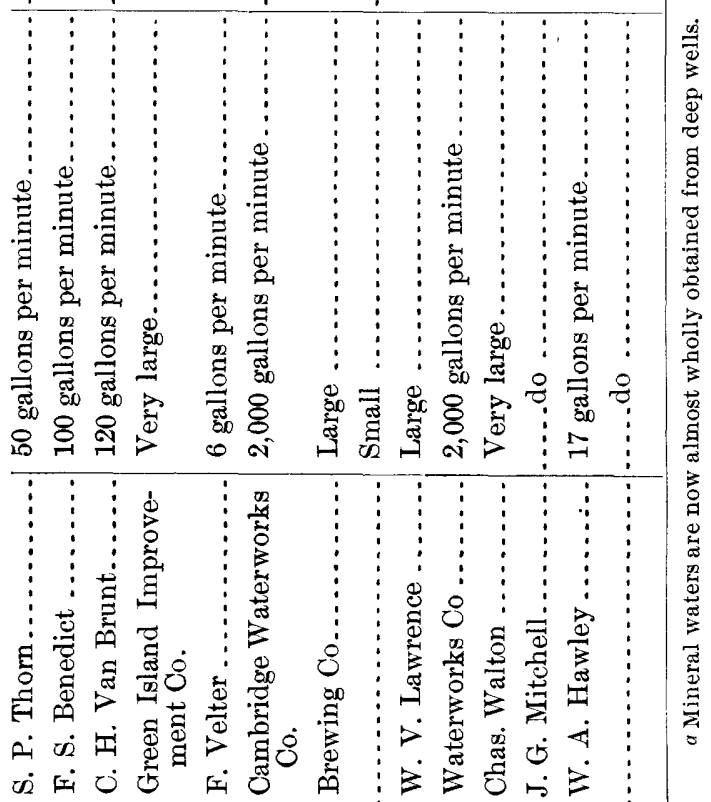

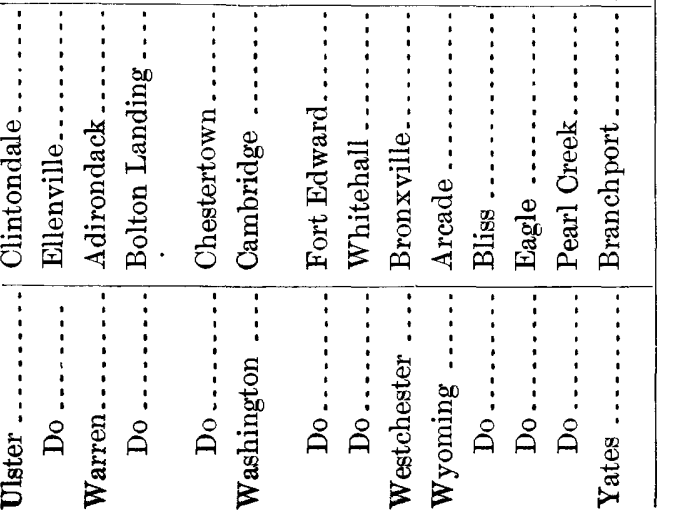




\section{PRINCIPAL PUBLICATIONS.}

Mineral springs of the United States, by A. C. Peale: Bull. U. S. Geol. Survey No. 32 , pp. $26-41$.

Mineral resources of New York, by F. J. H. Merrill: Bull. New York State Mus., Vol. III, 1895.

Artesian well prospects in the Atlantic Coastal Plain region, by N. H. Darton: Bull. U. S. Geol. Survey No. 138, pp. 22-38.

Preliminary list of deep borings in the United States, pt. 2, by N. H. Darton: Water-Supply and Irrig. Paper U. S. Geol. Survey No. 61, 1902, pp. 15-19.

New York [well and spring records], by F. B. Weeks: Water-Supply and Irrig. Paper U. S. Geol. Survey No. 102, 1904, pp. 169-206.

The new artesian well supply at Ithaca, N. Y., by Francis L. Whitney: WaterSupply and Irrig. Paper U. S. Geol. Survey No. 110, 1905, pp. 55-64.

Water resources of the Fort Ticonderoga quadrangle, Vermont and New York, by T. Nelson Dale: Water-Supply and Irrig. Paper U. S. Geol. Survey No. 110, 1905, pp. 126-129.

Water resources of the Taconic quadrangle, New York, Massachusetts, and Vermont, by F. B. Taylor: Water-Supply and Irrig. Paper U. S. Geol. Survey No. 110, 1905, pp. 130-133.

Water resources of the Watkins Glen quadrangle, New York, by R. S. Tarr: WaterSupply and Irrig. Paper U. S. Geol. Survey No. 110, pp. 134-140. 


\section{NEW JERSEY.}

By G. N. KnAPP.

\section{TOPOGRAPHIC PROVINCES.}

New Jersey has been divided into four provinces, or zones, on the basis of its physiographic features. These provinces are indicated on

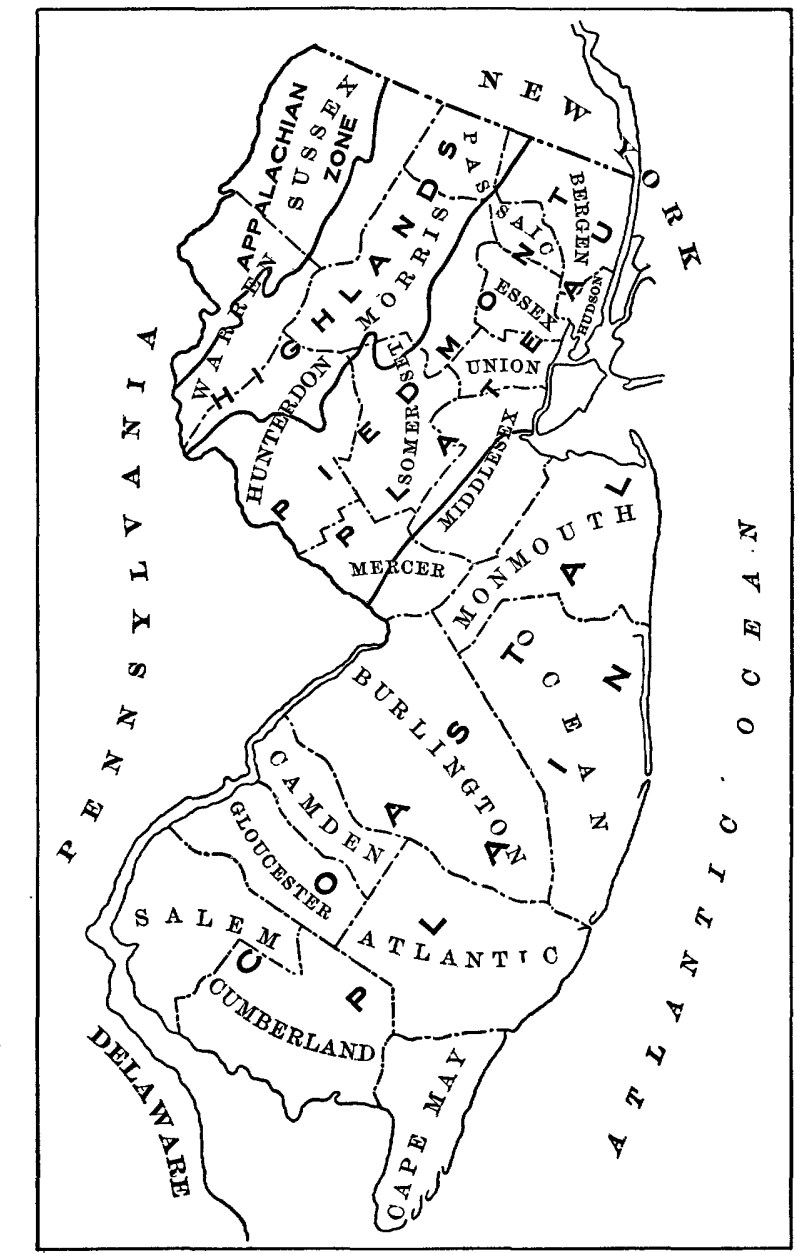

Fig. 18.-Subdivisions of New Jersey governing the appearance of underground water.

the accompanying sketch map (fig. 18) and are designated (1) the Appalachian, (2) the Crystalline Highlands, (3) the Piedmont, and (4) the 
Coastal Plain. ${ }^{a}$ The surface features of these several provinces, by reason of which they differ the one from the other, are in large measure simply the outward manifestations of geologic characters, structural and lithologic, which are inherent in the terranes of the different provinces and which have found topographic expression through subaerial and stream degradation.

As might be expected the underground or deep waters of the State sustain relations that differ in the different provinces and that are more or less characteristic of them. Rocks so different in structure and lithologic character as to give rise to topographic features that are as distinct and characteristic as are those of the several provinces might be expected to profoundly affect the disposition of underground water. This is, in fact, found to be true, and this subdivision of the State is regarded as the one best adapted to a general discussion of the deep waters.

\section{GEOLOGY AND WATER SUPPLY.}

APPALACHIAN PROVINCE.

The Appalachian province, or zone, is the northern extension in New Jersey of the great Appalachian mountain system. It is essentially coincident with the great Kittatinny Valley and Kittatinny Mountain.

The rocks consist of limestone, slates, conglomerates, sandstones, and quartzites, strongly infolded in anticlines and synclines whose axes run northeast and southwest. These primary folds have been more or less faulted and modified by dikes and other late intrusions. The whole series has been profoundly eroded, plains of degradation have been developed, truncating the old folds, and later broad, deep valleys have been developed parallel to the main axes of the folds. In these broad valleys the softer beds, such as limestones and shales, stand at angles that range from vertical to horizontal and dip in various directions. The ridges or mountains that inclose these valleys consist of the harder rocks, viz: Conglomerates, quartzites, slates, and sandstones, which rise more or less abruptly to heights of 1,000 or 1,500 feet above the valleys. The beds themselves stand at various angles, commonly approaching verticality.

The various beds of the Kittatinny Valley have in large measure lost through metamorphism whatever porosity they may once have had. The sandstones have become quartzites, more or less dense; the conglomerates have suffered a like modification, reducing their porosity to a minimum, and the other rocks have undergone similar changes, tending to increase their density. The rocks have, however, been fractured at various times, so that joints oceur more or less abundantly 
throughout the beds, admitting water to unknown depths. In the limestones solution has developed cavities and more or less definite underground courses.

The rocks then of the Appalachian province are relatively impervious and do not carry a large volume of water. The water that penetrates deeply does so by virtue of secondary structures and other modifications that do not stand in close relation to the primary structure.

Therefore a knowledge of the structure, which is regular enough to be determined with considerable definiteness, is not of so much service in locating successful wells as might be expected. The water seems capricious in its occurrence. The data available, however, show but few deep wells in this province-too few to be made the basis of final conclusions, so that the great Kittatinny Valley has yet to be thoroughly tested for its available deep water supply.

\section{CRYSTALLINE HIGHLANDS PROVINCE.}

The Crystalline Highlands, as the name suggests, consists more largely of crystalline rocks - granites, schists, and gneisses. The great structural lines of the province run northeast and southwest, like those of the Appalachian zone, but this region has been subject to more profound metamorphism and the beds have been repeatedly broken and faulted at widely separate time intervals. Intrusive rocks have been injected as dikes and masses at different times, secondary structures have very generally destroyed or replaced the original ones, and along with this have gone replacement and interehange of the mineral constituents of the rocks.

In the Crystalline Highlands, therefore, the structure is too complex and too indefinite to aid one in a practical way in predicting the result of wells, and the terranes contain no well-defined porous beds that in a true sense can be called water bearing in contradistinction to others. The rocks, however, as a whole, are more generally permeated by water than in the Appalachian zone, so that wells put down indiscriminately give a larger percentage of satisfactory wells in the former than in the latter region. We know from the numerous iron mines scattered through the Highland region that the permeation of these old crystallines by water, while very general, is by no means uniform; for some mines encounter large volumes of water, greatly to their detriment, whereas others are comparatively dry. The relation, if any, that exists between the local rock structure or the depth of the mime and the volume of water encountered is not apparent.

In the Highland province there are some areas that form notable exceptions to the structure above outlined; such, for instance, as the Green Pond mountain belt, where the rocks and structure are analogous to the infolding of the Appalachian zone. In these exceptional areas the deep waters behave much as they do in the Kittatinny region. 
The numerous streams, as yet not polluted, afford an abundance of excellent water. This, together with the cost of drilling in such hard rock, i. e., $\$ 5$ to $\$ 10$ a foot, has heretofore limited the number of deep wells.

This province, however, is being invaded by suburban homes and country residences, and we may expect that in the near future more deep wells will be bored.

\section{PIEDMONT PROVINCE.}

The Piedmont province is essentially the area of the Newark system. The Newark consists of three series of beds which, from base upward, are the Stockton, the Lockatong, and the Brunswick. The Stockton consists of light-colored sandstones and conglomerates, more or less arkose, interbedded with a few red shales. It is the most permeable series of the Newark system. The Lockatong consists chiefly of flagstones and argillites, and is relatively impervious. The Brunswick series consists chiefly of shales, but includes also many beds of sandstone. It is less permeable than the Stockton.

The Newark system is traversed by a number of irregular faults whose throw is nearly sufficient to repeat the entire system at each successive fault. The prevailing dip of the beds is west and northwest, but more or less local warping and tilting that accompanied the faulting gave the beds many local variations in dip and strike. The structure of the Newark is further complicated by an irregular system of volcanic intrusive sheets and trap dikes that cut across the bedding at various angles.

The faulting of the Newark in a way to repeat the succession is a slight advantage in some situations, since it makes the Stockton beds more readily available for artesian water at some localities than they otherwise would be, but in other situations the faults cut off a we supply entirely, so that the advantage in one locality is in large measure offset by the disadvantage in the other. One familiar with the complex structure of the Newark can forecast the chances of obtaining artesian water at given points in the Piedmont province; but it would be difficult for one unfamiliar with the structure to make such forecasts.

The Newark system is thoroughly cut up by two or more systems of deeply penetrating joints, whose planes are nearly vertical and intersect one another at various angles. It is thought that the copious wells in the Newark draw their supply from these joints and fissures more largely than from the water that penetrates along the true bedding planes. Nearly one half of the northern end of the Piedmont province is, however, mantled by glacial drift which conceals many of the minor details of the Newark structure. This not infre- 
quently entirely precludes the possibility of calculating closely the chances of artesian water at certain points.

Of the three provinces thus far considered, the Piedmont carries vastly more deep water than either of the others. Moreover, the water is found in rocks that are drilled with comparative ease, and the chances of obtaining it can be foretold with much definiteness. Furthermore, the Piedmont is, by virtue of its geographic position, the most important of the three, since it includes what is and what always will be the most densely populated part of the State, in which the water supply will always be a paramount question.

\section{COASTAL PLAIN PROVINCE.}

The Coastal Plain differs from the three northern provinces in nearly every essential feature. First, it includes an area greater than the combined area of the other three provinces; second, as compared with the other provinces it is flat, there being no mountains and the maximun relief being less than 400 feet; third, its structure is of the simplest sort, for it consists of a succession of beds lying one upon the other in a simple monocline that dips seaward, the uppermost or youngest bed lying farthest southeast, and each successively older and lower bed reaching a little farther northwest; fourth, there have been no faults or folds of sufficient magnitude to appreciably affect the general structure; fifth, the beds are unconsolidated sands, clays, marls, and gravels, and lie in essentially the same position in which they were deposited; sixth, the terranes have not suffered any metamorphism that has appreciably affected their permeability to water.

The Coastal Plain province falls into two great geologic divisions or subprovinces, viz, the Cretaceous and the Tertiary. The Cretaceous occupies a relatively narrow belt that extends across the State, while the Tertiary covers the remainder of the province.

The Cretaceous has three major divisions, which, reckoned from base upward, are the Raritan, the Clay Marl series, and the Marl series. The Clay Marl series corresponds approximately but not exactly to the "Matawan" of the later nomenclature, while the Marl series includes approximately but not exactly the Monmouth, Rancocas, and Manasquan of later nomenclature.

The Raritan, though carrying important water beds at different stratigraphic horizons, does not admit of subdivision. The Clay Marl series, on the other hand, is readily subdivided into five beds, the lower two of which are impervious marl and clay and serve as a cover to the Raritan water-bearing sands. The stratum next above is a sand bed, which is 100 feet thick to the northeast, where it is an important water horizon; toward the southwest it pinches out entirely and disappears along the strike. Above this is an impervious marl and clay.

IRR $114-05-7$ 
Next comes a sand bed 100 feet thick to the southwest, where it is an important water horizon. To the northeast it becomes less important, partly by reason of its decrease in thickness in that direction and partly by a decrease in permeability.

The Marl series, like the Clay Marl series, is readily subdivided into five beds, the lower of which corresponds to the Lower Marl, approximately the "Navesink." Above this is the Red sand (Redbank). Toward the northeast it is a sand bed 100 feet thick, but toward the southwest it pinches out and disappears along the strike. Next above is the lower portion of the old Middle Marl bed-the marl proper. It constitutes a part but not all of the Sewell. Still higher is the Lime and "Yellow" sand; the upper part of the old Middle Marl bed, including the "Vincenttown" and more. This is an important water horizon all across the State. The top bed is the Upper Marl, a part of which is Eocene. It is the impervious cover to the preceding.

The second subprovince of the Coastal Plain, the Tertiary, is divided into two formations, the Kirkwood (Miocene), and the Cohansey (Pliocene?). The lower bed is the Kirkwood. It carries waterbearing sands at several different stratigraphic horizons. It is an important source of water at Atlantic City and at points farther south along the beach. Next higher is the Cohansey formation. It carries water at several different stratigraphic horizons and rivals the Kirkwood as a source of artesian water along the beach.

The structure of the Coastal Plain is extremely simple. The outcrop of the beds is known in great detail. Their dip is known, or is readily determinable, and the altitudes of the various beds can be closely estimated at all points. Still the predicting of artesian water at any given point is not a simple mathematical proposition. Two chief difficulties are experienced in predicting the results of wells: First, the thickening of the beds down the dip, seaward, has not been worked out in detail for individual beds; second, the permeability of the beds is a variable factor, whose exact value is yet to be determined.

In the following table the results of borings at a large number of localities on the Coastal Plain are presented:

Summary of well statistics in the more important of the Coastal Plain localities.

[Compiled from tables of N. H. Darton.a]

\begin{tabular}{|c|c|c|c|c|c|}
\hline \multirow{2}{*}{ Locality. } & \multicolumn{2}{|c|}{ Range of depth. } & \multicolumn{2}{|c|}{$\begin{array}{c}\text { Range of capacity } \\
\text { per minute. }\end{array}$} & \multirow{2}{*}{ Geologic horizons of water. } \\
\hline & From- & To- & From- & To- & \\
\hline & Feet. & Feet. & Gallons. & Gallons. & \\
\hline Asbury Park..... & 383 & 1,330 & 20 & 500 & Lower marl, Matawan, Raritan. \\
\hline Atlantic City.......... & 118 & 1,398 & 0 & 400 & $\begin{array}{l}\text { "Diatom bed," Cretaceous, Chesa- } \\
\text { peake. }\end{array}$ \\
\hline Atlantic Highlands ... & 108 & 480 & 80 & 250 & Matawan, Raritan. \\
\hline Barnegat Landing..... & $\ldots$ & 120 & & & \\
\hline Bayhead ............ & 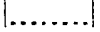 & 710 & & & Lower marl. \\
\hline
\end{tabular}

$a$ Bull. U. S. Geol. Survey, No. 138, pp. 42-48. 
Summary of well statistics in the more important of the Coastal Plain localities-Cont'd.

\begin{tabular}{|c|c|c|c|c|c|}
\hline \multirow{2}{*}{ Locality. } & \multicolumn{2}{|c|}{ Range of depth. } & \multicolumn{2}{|c|}{$\begin{array}{l}\text { Range of capacity } \\
\text { per minute. }\end{array}$} & \multirow{2}{*}{ Geologic horizons of water. } \\
\hline & From- & To- & From- & To- & \\
\hline Bayside . & \begin{tabular}{|c|} 
Feet. \\
\end{tabular} & $\begin{array}{r}\text { Feet. } \\
190\end{array}$ & $\begin{array}{r}\text { Gallons. } \\
0\end{array}$ & $\begin{array}{c}\text { Gallons. } \\
\text {............... }\end{array}$ & Unknown. \\
\hline Beach Haven... & 430 & 575 & 10 & 125 & $\begin{array}{l}\text { Bed C, Atlantic City; bed E, Atlantic } \\
\text { City. }\end{array}$ \\
\hline Berkeley Arms. & $\ldots$ & 470 & $\ldots$ & 60 & 960 feet at Atlantic City(?). \\
\hline Bordentown..... & 119 & 195 & $\cdots$ & Many. & Raritan, basal Raritan. \\
\hline Bridgeton ......... & $\ldots$. & 90 & 0 & - $\ldots \ldots \ldots \ldots$ & Post-Chesapeake. \\
\hline Brigantine .... & $\cdots \cdot$ & 798 & $\ldots$ & $\cdot 100$ & 800 feet at Atlantic City. \\
\hline Burlington ....... & 135 & 253 & 0 & 25; plenty. & Raritan. \\
\hline Camden.......... & 112 & 152 & 16 & 150 & Basal Raritan. \\
\hline Cape May City . & $\cdots$ & 224 & & 75 & Upper Chesapeake. Unknown. \\
\hline Cape May Point. & .... & 360 & & $\begin{array}{l}\text { Fair sup- } \\
\text { ply. }\end{array}$ & Upper Chesapeake. \\
\hline Clayton ( 6 wells). & $\cdots$ & 105 & & Each, 150 & Post-Chesapeake(?). \\
\hline Collingswood.... & $\cdots$. & 196 & & $\begin{array}{l}\text { Fair sup- } \\
\text { ply. }\end{array}$ & Raritan. \\
\hline Columbus .. & 156 & 356 & & $\begin{array}{l}\text { 10; fairsup- } \\
\text { ply. }\end{array}$ & Raritan, basal Matawan. \\
\hline Crab Island.. & .. & 520 & & $\begin{array}{l}\text { Satisfac- } \\
\text { tory. }\end{array}$ & $b$ \\
\hline Englishtown . & $\cdots$ & 210 & 0 & ….......... & Matawan. \\
\hline Fellowship .... & $\ldots$. & 131 & $\ldots$ & Many. & Do. \\
\hline Fifields......... & $\cdots$ & 397 & 0 & .............. & Chesapeake. \\
\hline Freehold ........ & 172 & 322 & $25 ?$ & $\begin{array}{l}250 \text {; unsat- } \\
\text { isfacto- } \\
\text { ry. }\end{array}$ & Lower marl, Matawan. \\
\hline Glassboro.. & $\cdots$. & 511 & 0 & 100 & Post-Chesapeake, Matawan. \\
\hline Gloucester.... & 102 & 270 & 100 & 650 & $\begin{array}{l}\text { Basal Raritan, basal Matawan, Rari- } \\
\text { tan. }\end{array}$ \\
\hline Great Sedge Island. & $\cdots$ & 320 & & 100 & \\
\hline Greenwich ..... & $\ldots$ & 690 & 0 & ............ & Lower marl. \\
\hline Harrisia......... & $\cdots \cdot$ & 375 & & ........... & \\
\hline Harrisonville.... & $\ldots$ & 122 & $\cdots$ & Plenty. & Middle marl. \\
\hline Hartford .......... & $\cdots$ & 187 & 0 & $\ldots \ldots$ & Matawan. \\
\hline Harvey Cedars ........ & 240 & 500 & $\cdots$ & 100 & \\
\hline Hightstown ....... & 201 & 500 & 12 & 70 & Matawan, Raritan, basal Raritan \\
\hline Holmdel ........ & $\cdots$ & 601 & 0 & … & Raritan. \\
\hline Jamesburg ..... & $\ldots$ & 481 & & 52 & Do. \\
\hline Keyport . ....... & $\cdots$ & 242 & $\cdots$ & 12 & Do. \\
\hline Lake Como..... & $\ldots$ & 585 & & $\cdots$ & Lower marl. \\
\hline Lakewood...... & & 475 & & $\cdots$ & Do. \\
\hline Longport ....... & & 803 & & 180 & Bed G, Atlantic City. \\
\hline Lucaston ...... & $\cdots \cdot$ & 110 & & $\cdots$ & Middle marl. \\
\hline Mantoloking .... & 175 & 922 & & $\cdots$ & $\begin{array}{l}\text { Bed C, Atlantic City, lower marl, Mat- } \\
\text { awan. }\end{array}$ \\
\hline Maple Shade ..... & $\cdots$ & 375 & & n........... & Basal Raritan. \\
\hline Marlton .......... & 102 & 365 & 0 & $\begin{array}{l}20 \text {; fair to } \\
\text { plenty. }\end{array}$ & Redbank, lower marl(?), Matawan. \\
\hline Matawan..... & $\cdots .$. & 100 & & (n.......... & Matawan. \\
\hline Mays Landing........... & 100 & 176 & 7 & 25 & $\begin{array}{l}428 \text { feet, Atlantic City(?), bed C, Atlan } \\
\text { tic City (?). }\end{array}$ \\
\hline Mechesatankin Creek . & & 158 & & $\begin{array}{l}\text { Unsatis- } \\
\text { factory. }\end{array}$ & \\
\hline Medford... & 126 & 183 & & $\begin{array}{l}\text { Plenty; } \\
\text { satis - } \\
\text { factory; } \\
200 .\end{array}$ & Redbank, lower marl. \\
\hline
\end{tabular}


Summary of well statistics in the more important of the Coastal Plain localities-Cont'd.

\begin{tabular}{|c|c|c|c|c|c|}
\hline \multirow{2}{*}{ Locality. } & \multicolumn{2}{|c|}{ Range of depth. } & \multicolumn{2}{|c|}{$\begin{array}{l}\text { Range of capacity } \\
\text { per minute. }\end{array}$} & \multirow{2}{*}{ Geologic horizons of water. } \\
\hline & From- & To- & From- & To- & \\
\hline Millville..... & $\begin{array}{r}\text { Feet. } \\
150\end{array}$ & $\begin{array}{c}\text { Feet. } \\
160\end{array}$ & Gallons. & $\begin{array}{l}\text { Gallons. } \\
\text { Satisfac- } \\
\text { tory. }\end{array}$ & \\
\hline Monmouth Beach .. & $\cdots$ & 380 & & .............. & Matawan. \\
\hline Monmouth Park . & & 385 & $\cdots$ & 75 & Do. \\
\hline Moorestown ..... . & $\cdots$. & 150 & & …........ & Basal Matawan. \\
\hline Mount Ephraim. . & & 130 & & $\begin{array}{l}\text { Sa tisfac- } \\
\text { tory. }\end{array}$ & Basal Matawan(?). \\
\hline Mount Holly .. & $\cdots$ & 675 & & $\cdots$ & Raritan. \\
\hline Mullica Hill... & $\cdots$ & 102 & & ... & Redbank. \\
\hline Ocean Beach .......... & 480 & 485 & 25 & 50 & Lower marl. \\
\hline Ocean City ..... & 760 & 800 & & 140 & Chesapeake diatom bed. \\
\hline Ocean Grove ......... & 420 & 1,134 & & 40 & Lower marl, Matawan. \\
\hline Pavonia ............ & 112 & 174 & & 275 & Raritan, basal Raritan,crystalline rock. \\
\hline Perth Amboy.......... & 130 & 470 & 0 & .............. & Basal Raritan, $70-470$ feet in gneiss. \\
\hline Pleasant Mills....... & $15 \hat{8}$ & 201 & & $\begin{array}{l}\text { 500; unsat- } \\
\text { is f a c - } \\
\text { tory. }\end{array}$ & 658 feet at Ocean City(?), Chesapeake. \\
\hline Port Monmouth... & …. & +100 & & Few. & Matawan. \\
\hline Point Pleasant ..... & $\cdots$. & 806 & & 45 & Do. \\
\hline Port Norris ...... & $\cdots$ & 200 & & 1 & \\
\hline Port Republic ....... & $\cdots$ & 151 & & $\cdots$ & 428 feet, Atlantic City(?). \\
\hline Quinton .............. & 248 & 275 & $\cdots$ & 55 & Redbank. \\
\hline Rancocas........ & -... & 124 & & $\cdots$ & Basal Matawan. \\
\hline Redbank ....... & $\cdots$ & 230 & $\cdots$ & 165 & Lower marl, Matawan. \\
\hline Riverside (8 wells) & $\cdots$ & 200 & 18 & Each; 40 & Raritan(?). \\
\hline Rumsen Neck ...... & .. & 210 & & 60 & Matawan. \\
\hline Runyon Station ..... & .... & 160 & 0 & …..... & \\
\hline Sayreville ............. & $\cdots$ & 976 & & Many. & Basal Raritan, 80,976 feet in gneiss. \\
\hline Sea Girt ............ & $\ldots$. & 755 & $\ldots$ & 50 & Matawan. \\
\hline Seabright...$\ldots \ldots \ldots$. & 125 & 258 & อ̄ & 210 & Lower marl, Matawan. \\
\hline Sea Island City ....... & ......... & 380 & $\ldots$ & 30 & Above diatom bed. \\
\hline Seven Islands ......... & 408 & 535 & 60 & 70 & $\begin{array}{l}\text { Bed E, Atlantic City; bed C, Atlantic } \\
\text { City(?). }\end{array}$ \\
\hline Sewell........ & & 420 & ... & 25 & Basal Matawan. \\
\hline Shrewsbury ....... & $\cdots$ & 200 & 0 & & Lower marl. \\
\hline South Amboy........... & $\cdots$ & 105 & & & Basal Raritan. \\
\hline South Beach Haven... & $\cdots$ & 425 & & $10 ?$ & Bed C, Atlantic City. \\
\hline Spring Lake........... & ..... & 465 & $\cdots$ & Many. & Lower marl. \\
\hline Stockton.......... & 116 & 130 & & 875 & Basal Raritan, Raritan. \\
\hline Straight Creek... & $\cdots \cdot$ & 100 & & Many. & \\
\hline Trenton ............ & $\cdots$ & 160 & $\ldots$ & Many; 200 & Post-Chesapeake(?). Basal Raritan. \\
\hline Vineland.......... & $\cdots$ & 205 & & 20 & Post-Chesa peake. \\
\hline Waretown .............. & $\cdots$. & 280 & & 20 & Bed E, Atlantic City. \\
\hline Wenonah.............. & 196 & 341 & & $\cdots$. & Basal Matawan, Matawan. \\
\hline Weymouth ............. & ... & 106 & 52 & 70 & $\begin{array}{l}\text { Bed C, Atlantic City(?); } 650 \text { feet at } \\
\text { Atlantic City(?); bed C Atlantic } \\
\text { City(?). }\end{array}$ \\
\hline Wildwood.. & 215 & 931 & 10 & $\begin{array}{l}\text { 300; unsat- } \\
\text { isfactory. }\end{array}$ & $\begin{array}{l}\text { Upper Chesapeake, } 240 \text { feet below great } \\
\text { diatom bed; in great diatom bed. }\end{array}$ \\
\hline Winslow...... & 135 & 145 & 20 & 40 & Chesapeake, 960 feet at Atlantic City (?). \\
\hline Woodbury ............ & 113 & 163 & & 8 & Matawan, basal Matawan. \\
\hline Woodstown..... & 139 & 776 & $\cdots$ & 360 & Basal Matawan, Redbank, Raritan. \\
\hline
\end{tabular}


SUMMARY. OF WATER RESOURCES.

The accompanying table brings into prominence many important relations and suggests many more.

Distribution of wells by provinces.

\begin{tabular}{|c|c|c|c|c|}
\hline & $\begin{array}{c}\text { Appa- } \\
\text { lachian. }\end{array}$ & $\begin{array}{l}\text { Crystalline } \\
\text { Highlands. }\end{array}$ & Piedmont. & $\begin{array}{l}\text { Coastal } \\
\text { Plain. }\end{array}$ \\
\hline Area in square miles ........ & 547.0 & 945.0 & $1,463.0$ & $5,099.0$ \\
\hline Approximate population......... & $24,201.0$ & $76,029.0$ & $1,222,586.0$ & $495,072.0$ \\
\hline 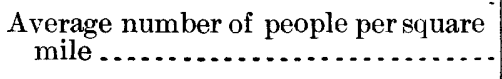 & 44.2 & 80.4 & 836.3 & 97.7 \\
\hline $\begin{array}{l}\text { Maximum density of population per } \\
\text { square mile per township.......... }\end{array}$ & $1,590.0$ & $8,475.0$ & $22,560.0$ & $14,492.0$ \\
\hline $\begin{array}{l}\text { Minimum density of population per } \\
\text { square mile per township........... }\end{array}$ & 23.0 & 26.0 & 37.0 & 6.0 \\
\hline Records of wells $\ldots \ldots \ldots \ldots \ldots \ldots$ & 23.0 & 31.0 & 547.0 & 998.0 \\
\hline $\begin{array}{l}\text { Average number of square miles to } \\
\text { each well } . . . .\end{array}$ & 24.0 & 30.0 & 26.0 & 5.0 \\
\hline
\end{tabular}

It will be noticed that of the 1,600 wells catalogued, nearly 1,000 are in the Coastal Plain province. These range in depth from 50 to 2,300 feet and probably 90 per cent of them are of the true artesian typethat is, they draw their water from beds whose catchment area is remote, and the water in the wells rises nearly or quite to the surface, and frequently above the surface. Of the 550 wells in the Piedmont Plain very few are of the true artesian type. They range in depth from 50 to 2,300 feet. Many of them yield large volumes of water and a few of them flow, but, as before suggested, they probably draw their supplies largely from the joints and the secondary structures of the rocks. Of the 50 or 60 wells in the two northern provinces, only a few are truly artesian. They are practically all simply deep reservoir-like holes into which water percolates from innumerable joints and fissures at all horizons. While the gathering ground of such waters may be remote from the wells, they belong in a different class from those of the Coastal Plain. It will be remembered that the wells here catalogued are the ones of which records have been obtained, and not the actual total number of wells in these provinces. There are undoubtedly many wells of which no records have been procured.

The Appalachian and Crystalline provinces are relatively sparsely settled. In them springs abound, and mountain streams, proverbially wholesome and as yet unpolluted, are numerous and well distributed, so that the demand for deep wells is not pressing. 


\section{DISTRIBUTION OF WELLS AND POPULATION.}

The Piedmont area includes two fairly distinct subprovinces. The first, including the northeast part of the area, in the vicinity of Essex and Hudson counties, is occupied by numerous cities, large and small, many of which are manufacturing centers, while the second, in the southwest portion, in the vicinity of Somerset County, is dominantly an agricultural region. The first of these subprovinces includes about one-fifth of the area of the Piedmont province and contains about nine-tenths of its population, the remaining one-tenth of the population being scattered over the southwestern four-fifths of the province. Of the 550 wells in the Piedmont province more than 500 occur in the densely populated region in its northeastern portion and the water, for the most part, is used for manufacturing purposes.

In the Coastal Plain province the densely populated districts are distributed around its periphery, the interior being more sparsely settled. The distribution of the artesian wells stands in fairly definite relation to the density of population. Along the seashore are many thriving towns and cities whose function is almost wholly that of ministering to the service of those in quest of health, recreation, and pleasure. These communities, while not absolutely dependent on artesian wells for their water, find them the most satisfactory available source of supply, and hence a large percentage of the wells are found along the coast.

The north and northwest border of this province, which is approximately the outcrop of the Cretaceous terranes, finds its interests divided between agriculture and manufacture. Artesian wells are abundant in this region but are not so deep as those along the coast, and are accordingly less expensive. They serve both the manufacturing and the agricultural interests. In fact, the distribution of the artesian wells is determined, first, by the availability of the water; second, by the density of the population, and third, by the character of the population.

\section{MINERAL SPRINGS.}

Sixteen mineral springs in New Jersey reported sales of water in 1902 , and many more are the site of pleasure resorts of more or less importance. The aggregate production for the year is given as 360,900 gallons, with a value of $\$ 41,875$. The springs reporting are as follows: ${ }^{a}$

Alpha Spring, Springfield, Union County.

Beacon Mountain Spring, Denville, Morris County.

Beech Springs, near Woodbury, Gloucester County.

Fowler's Deep Rock Artesian Well, Allwood, Passaic County.

Hatawanna Spring, Buddlake, Morris County.

Holly Springs, Swedesboro, Gloucester County. 
Indian Kalium Spring, Gloucester, Camden County.

Indian Spring, near Rockaway, Morris County.

Kalium Springs, Collingswood, Camden County.

Gakland Vernam Spring, near Oakland, Bergen County.

Pine Lawn Spring, Hohokus, Bergen County.

Trinity Springs, Ridgefield, Bergen County.

Turtle Hill Spring, Passaic, Passaic County.

Washington Mountain Spring, Pennington, Mercer County.

Washington Rock Spring, Warrenville, Somerset County.

Watchung Spring, Plainfield, Union County.

\section{PRINCIPAL PUBLICATIONS.}

[Artesian wells of New Jersey], by Lewis Woolman and others. A large number of references and reports on the artesian wells of New Jersey are contained in the New Jersey Geological Survey Reports, beginning with the year 1857 and extending down to the present time. (See indexes of individual reports.)

Mineral springs of the United States, by A. C. Peale: Bull. U. S. Geol. Survey No. 32 , pp. 42-43.

Artesian well prospects in the Atlantic Coastal Plain region, by N. H. Darton: Bull. U. S. Geol. Survey No. 138, 1896, pp. 39-115.

Preliminary list of deep borings in the United States, pt. 2, by N. H. Darton. WaterSupply and Irrig. Paper U. S Geol. Survey No. 61, 1902, pp. 12-14.

Water resources of the highlands of New Jersey, by Laurence La Forge: Water-Supply and Irrig. Paper U. S. Geol. Survey No. 110, 1905, pp. 141-155. 


\section{PENNSYLVANIA.}

By M. L. Fuller.

TOPOGRAPHY.

There are three distinct topographic belts in Pennsylvania: (1) A southeastern belt, whose northern boundary starts about 10 miles southeast of Easton and passes southwestward, just south of Reading and Harrisburg, to a point a few miles west of Gettysburg; (2) a central belt, lying north and west of the first, whose northern boundary reaches from the northeastern part of the State westward and southwestward, past Williamsport, Lock Haven, and Altoona, to the southeastern portion of Somerset County; and (3) a northwestern belt which embraces the entire northern and western portions of the State. (See fig. 14.)

The eastern belt, known as the Piedmont Plateau, is in general of low elevation, and consists of a broadly rolling surface with few high hills. The central belt, constituting the Appalachian Mountains and Valley, consists of a large number of long, straight, or gently curving ridges, alternating with deep valleys, the widest of which is the Cumberland or Shenandoah. Many of these ridges rise to altitudes ranging between 1,500 and 2,500 feet. The third belt, known as the Allegheny Plateau, is a broad surface, cut throughout its extent by streams which now flow in deep and frequently canyon-like valleys. A few ridges rise above the common level of this upland, but the plateau has a general southwestward slope, and varies in altitude from about 2,000 feet in the northern portion of the State to approximately 1,200 feet in the southwestern portion.

\section{GEOLOGY.}

The geologic divisions correspond in general with those of topography; in fact, the geology has governed the character of the topography throughout the State. The southeastern topographic belt, or Piedmont Plateau, is underlain largely by crystalline rocks which have been very evenly eroded and consequently present few conspicuous topographic features. Along the northern border of this belt is a 
band of soft Triassic shales and sandstones of a topography similar to that of the adjoining crystalline area. The continuity of the belt is, however, broken by a series of folded Cambrian and Silurian quartzites and limestones that extend from near Trenton westward across the Susquehanna to the southeast corner of Adams County. The cities of York and Lancaster are located in this belt, while Phœnixville, Norristown, and Trenton lie just outside its borders.

The rocks of the middle topographic belt, which is characterized by prominent ridges, consist mainly of strongly folded beds of Cambrian, Silurian, and Devonian age, but the folded rocks of the anthracite coal basin and of the Broadtop coal basin in the south-central portion of the State are of Carboniferous age.

The rocks of the remaining or plateau portion of the State are Devonian and Carboniferous, the former constituting the surface in the northern and northeastern portion of the State and the latter in its western part. The rocks of this belt are characterized in general by

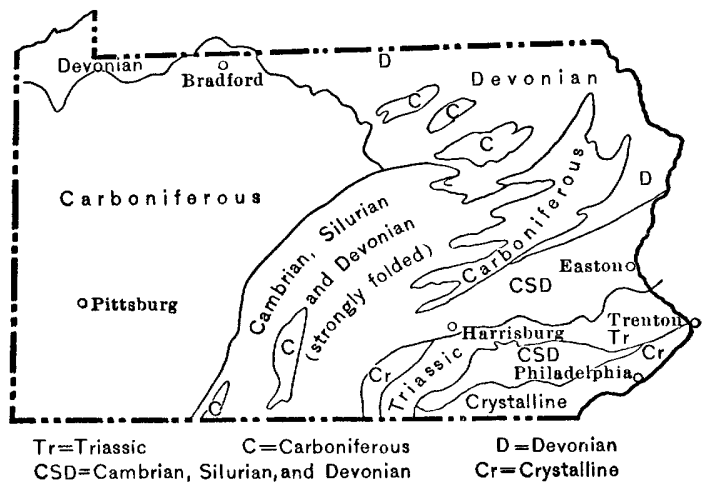

FIG. 19.-Geologic subdivisions of Pennsylvania.

very moderate folding, although the rocks of Laurel Hill and other ridges in the soutbwestern portion of the State show high dips. The folds generally decrease uniformly in magnitude as their distance from the Appalachian Front increases, until in the northwestern part of the State only slight and irregular undulations can be detected. It is along the crest of the anticlines that the lower Devonian rocks are brought to the surface in the northern part of the State.

\section{SOURCES OF WATER SUPPLY.}

\section{STREAMS AND LAKES.}

By far the larger number of the streams of Pennsylvania rise either in the mountainous regions of the Appalachian belt or in the highlands of the Allegheny Plateau. In general they have their sources in rugged forest-covered areas remote from habitations, and for considerable distances flow with their original purity through thinly 
populated districts. Even within a few miles of some of the large cities supplies from unpolluted streams may be procured. The waters of the larger streams, however, are generally polluted and unsafe for domestic use except where they are subjected to some process of purification. There are no large natural lakes within the State, but a few small ponds are found in depressions in the drift on some of the flat mountain tops and elsewhere in its northern portion. These ponds are seldom of any value as a source of water supply.

\section{WELLS.}

The drift.-The glacial drift in Pennsylvania is confined to the northern half of the State. The glacial boundary enters from the east at a point not far from Easton and passes northwestward to the New York line not far from Bradford. Here it leaves the State for a few miles, but soon turns south again, reenters the State and passes southwestward to a point a few miles north of Ohio River at the western border of the State.

In the area south of this line the loose materials at the surface, except in the river and stream valleys, consist of fragments of rock which have been broken up to form a stony soil under the action of the weather. North of the glacial boundary this residual soil has been reworked by glacial action and mixed with foreign material brought down from the north, the whole being left as a heterogeneous stony mantle, known as till, covering the surface. In addition to the till many deposits of gravel or sand were laid down in the valleys by streams flowing from the glacier.

The till usually contains a considerable percentage of clay and is not usually a satisfactory source of water. Nevertheless it furnishes small supplies to wells at many points throughout the northern portion of the State. The water follows rather definite courses through the material and its occurrence can not always be predicted. Its amount is almost always small, but it is of very fair quality. Springs are common, but are usually small and of little economic value.

Stream deposits.-In the stream deposits, which consist largely of gravel and sand, great quantities of water are stored, especially in the larger river valleys. The great absorptive power of these materials is strikingly shown by their rapid absorption of the mountain streams which emerge upon them. Wells driven but a few feet into such deposits often find abundant supplies. Their waters are almost always of excellent quality if taken at sufficient depth to be out of the zone of pollution from the surface.

Crystalline rocks. - The crystalline rocks consist of gneisses and similar granitic rocks. In general they carry but little water, for their porosity is small and they are not characterized by bedding planes that 
offer easy passages for water. These rocks are, however, cut by more or less vertical joints which admit considerable quantities of water under favorable conditions. Wells drilled in the crystalline rocks, especially in Philadelphia and vicinity, have frequently obtained moderate to good supplies at depths of from 100 to 300 feet. As a rule, wells that fail to obtain a supply within 300 feet of the surface will not afford much water at greater depths. Springs are relatively few in number and small in size, and are seldom used except in the vicinity of the large cities, where they furnish considerable quantities of water for table use.

Triassic rocks. - The Triassic rocks, the extent of which has already been indicated, consist of shales and soft sandstones, frequently stained red by iron oxide. The sandier beds contain a large quantity of water, a cubic foot sometimes holding a quart or more. Many wells have been drilled into these rocks in the towns scattered along their outcrop and considerable supplies have been obtained in some places. The waters, however, are liable to be strongly mineralized and in some cases it is impossible to use them in boilers. Springs occur in the Triassic rocks, but are not commonly important.

Cambrian and Silurian rocks.-The Cambrian and Silurian rocks consist of quartzites, limestones, and shales. They are characterized throughout, as has already been indicated, by strong folds, the rocks in many instances being almost on edge. The outcrops of the formations generally occur, therefore, as rather narrow, straight, or gently curving bands, although belts of considerable width are found where the folds are more open.

The true quartzites are dense, compact, and nonporous, exhibit very little jointing, and are frequently destitute of recognizable bedding planes. Under such conditions they are practically destitute of water. Some of the beds, however, especially the Medina and Oriskany sandstones, are less dense, and carry water which issues as fine large springs where the outcrops are favorable. The limestones, which include the Trenton and Lower Helderberg, are rather dense and carry water only in solution channels. For this reason the finding of water in them is uncertain, and they are, therefore, rarely a source of supply, although in some cities and towns deep wells have obtained satisfactory supplies from these rocks. There are many fine springs along the edges of the limestone areas, but in the central portion of the outcrops cisterns are mainly relied upon for water for domestic purposes.

The shales carry some water in their bedding planes and in sandy interbedded layers. Small springs are fairly common, and in the less strongly folded portions wells usually obtain moderate supplies.

Devonian rocks. - The Devonian rocks, as already indicated, occur to some extent infolded with the Cambrian and Silurian rocks, and are also brought to the surface by gentle folds in the northern portion of 
the State. They consist largely of shales, although sandstones are frequently present, especially in the subdivision of the Devonian known as the Catskill. Limestones are occasionally present. Springs are numerous in the areas where the Devonian shales and limestones outcrop, but they are small as compared with the springs of the Cambrian and Silurian areas. They afford, nevertheless, pure supplies for a large number of the inhabitants in the areas in which they occur. Wells also generally obtain fair supplies. In the synclines or basins flowing water is not uncommonly obtained by the deeper wells, but, because of the abundance of spring water and of water in the drift, deep wells are not often sunk.

Carboniferous rocks.--The Carboniferous rocks consist of a thick series of sandstones, shales, limestones, and coals. The limestones are generally only a few feet thick, but some of the beds may run up to 50 or 100 feet, or even more. They are not prominent water bearers, although small supplies are almost always obtained either at their upper surfaces or from some of their bedding or joint planes.

The Carboniferous shales, like the Devonian, frequently carry water along their bedding planes and in their interbedded sandy layers, but though giving rise to a considerable number of springs and furnishing supplies for many shallow wells, they are not conspicuously water bearing.

Water is frequently found associated with the coals, but is almost always highly charged with ferrous sulphate, resulting from the decomposition of the pyrite in the coal. Sandstones are often of great thickness and are fairly open and porous. Where above drainage level they commonly carry relatively little water, but below this level they are often saturated, and drilled wells penetrating them generally obtain good supplies. Where the rocks lie a considerable distance below the surface, however, the fresh water is liable to be replaced by salt water or by oil; hence deep wells are sometimes of little value as sources of water supply. Flowing water is frequently obtained in the synclines or basins and elsewhere where the conditions are favorable, but the water will seldom rise more than a few feet above the surface, and pumping is almost universally necessary to raise it for industrial uses. In general, fresh waters in the Carboniferous and Devonian rocks are found within 500 feet of the surface. Below this point the rocks are in some places entirely destitute of water, and in others carry salt water as indicated above.

Coastal Plain deposits. - The eastern portion of Philadelpbia is underlain by Coastal Plain formations, consisting of the lower beds of the Raritan-Potomac deposits. These beds are water bearers and have been tapped by a number of wells in the city. 
MINERAL SPRINGS.

The waters of Pennsylvania, except those of the Triassic area, of the limestones, and those associated with coals, are usually low in mineral matter. There are, however, scattered throughout the State a number of deep-seated springs the waters of which are mineralized. Many of these mineral waters are bottled and sold commercially, and resorts of importance have been developed about others. The mineral springs are not confined to any one class of rocks, but are found in all of the types described. The following springs reported shipments in 1902: ${ }^{a}$

Artesia Spring, Harrison Valley, Potter County.

Bedford Chalybeate Spring, Bedford, Bedford County.

Bedford Mineral Springs, near Bedford, Bedford County.

Black Barren Mineral Spring, Pleasant Grove, Lancaster County.

Buena Vista Springs, Buena Vista, Franklin County.

Charmian Mineral Spring, Charmian, Franklin County.

Cloverdale Artesian Lithia Spring, Newville, Cumberland County.

Corry Artesian Mineral Spring, Corry, Erie County.

Cresson Springs, Cresson, Cambria County.

De Vita Mineral Springs, Cambridge Springs, Crawford County.

East Mountain Lithia Well, near Factoryville, Wyoming County.

Ephrata Mountain Crystal Spring, near Ephrata, Lancaster County.

Glen Summit Spring, Glen Summit, Luzerne County.

Gray Mineral Spring, Cambridge Springs, Crawford County.

Imperial Spring, Angelica, Berks County.

Korrylutz Well, Corry, Erie County.

Magnesia Spring, Cambridge Springs, Crawford County.

Malvern Spring, Malvern, Chester County.

Parker Mineral Spring, Gardeau, McKean County.

Pavilion Spring, South Mountain, Wernersville, Berks County.

Petticord Mineral Spring, Cambridge Springs, Crawford County.

Pulaski Natural Mineral Spring, Pulaski, Lawrence County.

Rennyson Tredyffrin Spring, Rennyson, Chester County.

Ross-common Springs, Windgap, Monroe County.

Saegertown Mineral Spring, Saegertown, Crawford County.

Sizer Mineral Spring, Sizerville, Cameron County.

Spruce Hollow Mineral Spring, near Northumberland, Northumberland County.

The J. W. Lang Mineral Well, Venango, Crawford County.

Tuckahoe Mineral Springs, Northumberland, Northumberland County.

Whann Alkaline Lithia Mineral Springs, near Franklin, Venango County.

White House Spring, Neversink Mountain, Reading, Berks County.

The aggregate amount of water sold in 1902 is given as 4,567,260 gallons, valued at $\$ 1,124,532$. 


\section{PRINCIPAL PUBLICATIONS.}

Mineral Springs of the United States, by A. C. Peale: Bull. U. S. Geol. Survey No. 32, pp. 44-49.

Artesian-rvell prospects in the Atlantic Coastal Plain region, by N. H. Darton: Bull. U. S. Geol. Survey No. 138, pp. 115-117.

Preliminary list of deep borings in the United States, pt. 2, by N. H. Darton: Water-Supply and Irrig. Paper U. S. Geol. Survey No. 61, 1902, pp. 29-42.

Water resources of the Philadelphia district, by F. Bascom: Water-Supply and Irrig. Paper U. S. Geol. Survey No. 106, 1904.

Water resources of the Chambersburg and Mercersburg quadrangles, Pennsylvania, by G. W. Stose: Water-Supply and Irrig. Paper U. S. Geol. Survey No. 110, 1904, pp. 156-158.

Water resources of the Curwensville, Patton, Ebensburg, and Barnesboro quadrangles, Pennsylvania, by F. G. Clapp: Water-Supply and Irrig. Paper U. S. Geol. Survey No. 110, 1904, pp. 159-163.

Water resources of the Elders Ridge quadrangle, Pennsylvania, by R. W. Stone: Water-Supply and Irrig. Paper U. S. Geol. Survey No. 110, 1904, pp. 164-165.

Water resources of the Waynesburg quadrangle, Pennsylvania, by R. W. Stone: Water-Supply and Irrig. Paper U. S. Geol. Survey No. 110, 1904, pp. 166, 167.

Well records. (See reports of State Geological Survey of New Jersey.) 


\section{DELAWARE.}

By N. H. Darton.

\section{GEOLOGY.}

This State lies almost entirely on the Coastal Plain, across which it extends diagonally to the Atlantic Ocean. The crystalline rocks emerge at the surface in the extreme northern portion of the State, but are deeply buried under the Coastal Plain deposits to the southeast. The general structure is shown in section 1, Pl. VII. The topography of the State is relatively simple, consisting of a general terrace plain averaging about 50 feet in altitude and a small area of higher rolling hills north and west of Wilmington. The geologic formations are as follows:

\begin{tabular}{|c|c|c|}
\hline Formation. & Characteristics. & Age. \\
\hline Columbia .... & Sands, loams, and gravel. & Pleistocene. \\
\hline Chesapeake..... & $\begin{array}{l}\text { Sands, clays, infusorial earth, and } \\
\text { marl. }\end{array}$ & Miocene. \\
\hline Pamunkey.. & Brown sand and marl. & Eocene. \\
\hline Rancocas .. & Middle marl ..... & Later Cretaceous. \\
\hline Redbank . & Sands and marl....... & Do. \\
\hline Navesink . & Lower marl ........ & Do. \\
\hline Matawan .... & Clay marl and sand..... & Do. \\
\hline Raritan and Potomac. & Clays and sands $\ldots \ldots$ & Early Cretaceous. \\
\hline Crystalline rocks ... & $\begin{array}{l}\text { Granite, gneiss, gabbro, limestone, } \\
\text { and quartzite. }\end{array}$ & \\
\hline
\end{tabular}

\section{WATER HORIZONS.}

As relatively few deep wells have been bored in Delaware, the water horizons have not been fully explored over a very wide area. The well at Middletown (see below) has obtained a fine supply of water from the Potomac formation, apparently from the basal beds, and it is probable that this water sheet extends from Wilmington past Middletown far southward. At Farnhurst it yields a moderate supply. The dip of the horizon to the south-southeast is about 30 feet to the mile, 
which carries it from the tide level at Wilmington to a depth of 165 feet at Farnhurst and 535 feet at Middletown. Water horizons above the lower beds of the Potomac formation and in the Matawan, Redbank, and Lower Marl, that occur in New Jersey, were not reported in the Middletown well, which probably indicates that these waters do not extend into Delaware. The principal Chesapeake horizons appear to be represented in Delaware, although the evidence in regard to their correlation is not conclusive. The basal Chesapeake water, so important in Maryland, has not been reached by the wells. The water from sands in the great diatom bed (the 525-foot horizon at Atlantic City) probably supplies the Dover and Mahon River wells with their large yields, while Milford and Lewes apparently obtain their waters from a stratum that lies just above the diatom bed. As the Kitts Hummock well draws from a bed about 125 feet above the horizon of Dover and Mahon waters, its water horizon can not be definitely correlated with any of those at Atlantic City. The Ocean City well in Maryland is a high Chesapeake horizon which probably extends into the southern edge of Delaware, but no wells have yet been sunk to it in that State.

\section{WATER SUPPLIES.}

\section{DEEP WELLS.}

There are only a few deep wells in the State, but they are all successful and nearly all furnish large supplies of water. The following is a list of some of the more important ones:

Partial list of deep wells in Delaware.

\begin{tabular}{|c|c|c|c|c|c|}
\hline Locality. & Depth. & $\begin{array}{l}\text { Diam- } \\
\text { eter. }\end{array}$ & $\begin{array}{l}\text { Capacity per } \\
\text { minute. }\end{array}$ & $\begin{array}{c}\text { Height to } \\
\text { which water } \\
\text { rises. }\end{array}$ & Remarks. \\
\hline Dover .... & $\begin{array}{l}\text { Feet. } \\
196\end{array}$ & $\begin{array}{r}\text { Inches. } \\
10\end{array}$ & $\left.\begin{array}{l}\text { Gallons. } \\
\text { Flows } 235 \\
\text { Pumps } 218\end{array}\right\}$ & $\begin{array}{l}\text { Feet. } \\
+6\end{array}$ & Water also at 157 feet. \\
\hline Clayton..... & 150 & 6 & 30 & +20 & No water at $85-150$ feet. \\
\hline Do.................. & 60 & & & . & \\
\hline Do ......... & 85 & $\ldots$ & Moderate. & & \\
\hline Farnhurst $\ldots . . . \ldots \ldots$ & 211 & & & & $\begin{array}{l}\text { Water also at } 40 \text { and } 60 \text { feet; } \\
\text { rock at } 211 \text { feet. }\end{array}$ \\
\hline Kitts Hummock....... & 110 & $1 \frac{1}{2}$ & Much. & $-2 \frac{1}{2}$ & \\
\hline Lewes ................ & 400 & 6 & 15 & To surface. & \\
\hline Mahon River......... & 206 & ........ & Much. & ....... & \\
\hline Middletown ........... & 535 & $10-8$ & 330 & -50 & $\begin{array}{l}\text { Fine quality of water; much } \\
\text { water also at } 475 \text { and } 530 \\
\text { feet. }\end{array}$ \\
\hline Middletown .... & 90 & $(?)$ & $(?)$ & (?) & \\
\hline Milford ............... & 160 & 4 & 60 & +2 & \\
\hline Do................ & 150 & 4 & 60 & +3 & \\
\hline Do...$\ldots \ldots \ldots \ldots$. & 34 & 4 & 50 & $\ldots .$. & \\
\hline $\begin{array}{c}\text { Wilmington (Stoekle } \\
\text { Brewery). }\end{array}$ & 400 & 8 & $15-18$ & 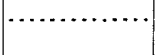 & In granite. \\
\hline $\begin{array}{l}\text { Wilmington (H. \& F. } \\
\text { Brewery). }\end{array}$ & 1,077 & & 10 & -25 & In granite, $96-1,077$ feet. \\
\hline $\begin{array}{l}\text { Wilmington (Hart \& } \\
\text { Bros.). }\end{array}$ & 200 & 6 & 75 & ...... & In granite, $36-200$ feèt. \\
\hline
\end{tabular}


WELL PROSPECTS.

From the evidence furnished by wells now yielding water supplies, it appears probable that the entire Coastal Plain area of Delaware is underlain by water. About Middletown and to the north the Potomac waters may be expected at depths which decrease at the rate of 30 feet per mile nearly to Wilmington, where the Potomac beds come to the surface. These waters may extend down the dip south of Middletown for many miles, but as no wells have been bored to them in that region no positive prediction can now be made as to the probability of obtaining water there. At Dover they should be expected at about 1,000 feet below the surface, if the southward dip continues at a uniform rate.

The Chesapeake waters begin a couple of miles north of Clayton and extend to the southern border of the State. The basal Chesapeake waters, which are important sources of supply in Maryland and in areas farther south, have not been tested by any wells in Delaware, but may be expected to extend over a wide area. The Clayton boring to 150 feet nearly reached this horizon, which probably lies about 450 feet below the surface at Dover. The Dover waters no doubt are widespread, for they are probably the same as those found at 234 feet at Federalsburg. The water horizon which appears to extend from Milford to Lewes probably also underlies all of eastern Sussex County, but it is not reported in any of the Maryland wells. In both Kent and Sussex counties there are almost certain prospects for Chesapeake waters at one horizon or another within 500 feet of the surface. Sections 1 and 2, Pl. VII, show the conditions so far as there are any data to present concerning them.

\section{PRINCIPAL PUBLICATIONS.}

(Well records.) See reports of State Geological Survey of New Jersey.

Artesian-well prospects in the Atlantic Coastal Plain region, by N. H. Darton: Bull.

U. S. Geol. Survey No. 138, 1896, pp. 117-124.

Preliminary list of deep borings in the United States, pt. 1, by N. H. Darton: Water-

Supply and Irrig. Paper U. S. Geol. Survey No. 57, 1902, p. 21.

IRR $114-05-8$ 


\title{
MARYLAND.
}

\author{
By N. H. Darton and M. L. Fuller. ${ }^{a}$
}

\section{TOPOGRAPHY AND GEOLOGY.}

The surface of Maryland may be divided into four topographic belts, determined by the composition and structure of the underlying rocks. Three of these, the Piedmont Plateau, the Appalachian Mountain, and Allegheny Plateau belts, are continuations of those developed in Pennsylvania and described in connection with that State. In addition to these there is in Maryland the great Coastal Plain belt, which stretches southeastward from a line extending from near Havre de Grace through Baltimore and Washington to Chesapeake Bay and the Atlantic coast. The materials of this belt are unconsolidated clays, sands, and gravels, mainly of Cretaceous and Tertiary age. When originally deposited the beds were very nearly horizontal, but they have been since tilted so that they now dip considerably to the southeast.

The Coastal Plain is moderately low and where not eroded by streams exhibits flat surfaces. Such flat areas, however, because of the extent to which erosion has taken place, are of no great extent.

The rocks of the Piedmont Plateau are mainly crystalline and include granites, diorites, and other igneous or metamorphic rocks, together with some schists, slates, and crystalline limestones. In altitude the belt is somewhat higher than the Coastal Plain area. Like the latter, it shows, in those portions untouched by streams, a nearly flat surface due, however, in this instance, to long-continued erosion at a period when the rocks stood near sea level, rather than to nearly level deposition, as in the Coastal Plain. The rocks, though deeply weathered, are harder than the Coastal Plain deposits and are less readily gullied by small streams. Moreover, they have been subjected to erosion for a much longer period than those of the Coastal Plain and more rounded forms have been developed.

Bordering the crystalline area and included partly within the area of Ordovician rocks to the west is a belt of Triassic sandstones and

$a$ The following account of the water resources of Maryland has been prepared by M. L. Fuller, but the portions relating to the Coastal Plain have been compiled from the report of Mr. N. H. Darton on Artesian-well prospects in the Atlantic Coastal Plain region: Bull. U. S. Geol. Survey No. 138, 1896. 
shales that ranges in width from 2 to 15 miles. The topography of this belt is similar to that of the Piedmont belt.

The Appalachian Mountain belt, as in Pennsylvania, consists of a series of strongly folded Cambrian, Ordovician, Silurian, and Devonian rocks, including a number of quartzites, sandstones, and limestones, lying mainly between Emmitsburg and Cumberland and striking northeast-southwest. Beyond Cumberland the rocks consist of moderately folded Devonian and Carboniferous strata, the harder beds of which give rise to ridges. These ridges are not, however, so strongly developed as those lying farther east, and in the areas between them plateaus similar to those of western Pennsylvania have been developed. As in the latter State the plateau in Maryland is deeply cut by the streams which drain it.

\section{WATER SUPPLIES.}

\section{SPRINGS.}

Springs are numerous throughout Maryland, but it is only in the limestones or coarse sandstones of the strongly folded Appalachian belt that they are commonly of any considerable size. In rocks other than limestones and sandstones the springs, though numerous, are small, but they nevertheless supply pure water for a large number of inhahitants in the more thinly settled districts.

In the crystalline rocks of the Piedmont Plateau springs are less common and are generally of small volume, but because of the demand for pure water for drinking purposes in the larger cities a number of such springs have been developed and their waters placed on the market. These are mainly in the vicinity of Washington and Baltimore.

The more porous beds of the Coastal Plain, where cut by ravines, give rise to numerous springs. These are commonly small and their water is frequently hard and is unsatisfactory for many purposes. Relatively little use is generally made of these springs, but a few of them that possess medicinal properties have been developed and their waters placed on the market.

The following is a list of springs reporting shipments in 1902: ${ }^{a}$

Blackiston Island Diuretic Mineral Spring, Blackiston Island, St. Mary County.

Bladensburg Spa, Bladensburg, Prince George County.

Carroll Springs, Forest Glen, Montgomery County.

Chattolanee Springs, Chattolanee, Baltimore County.

Elim or Willmead Spring, Oxenhill, Prince George County.

Mardela Mineral Spring, Mardela, Wicomico County.

Rock Hill Indian Spring, Rockville, Montgomery County.

Roland Park Artesian Well, Roland Park, Baltimore County.

Takoma Spring, Takoma Park, Montgomery County. 
Of these springs those in St. Mary, Prince George, and Wicomico counties are from Coastal Plain deposits. The remainder are probably from the crystalline rocks of the Piedmont Plateau. The aggregate production for 1902 is given as 488,228 gallons, with a value of $\$ 45,100$.

\section{STREAMS.}

The small streams in the mountainous regions of Maryland are mainly spring-fed and contain in their upper courses very pure water. They soon become contaminated, however, by refuse from manufactories and villages situated along their courses, and, although frequently used as a source of water supply, they can not be regarded as a desirable source of water for domestic use. Moreover, they are often highly charged with silt.

The streams of the Piedmont and Coastal Plain belts are, because of the relative density of population of those areas, even more liable to pollution than those of the mountainous area and are seldom, if ever, desirable sources of supply.

WELIS.

Allegheny Plateau.-The Allegheny Plateau is developed only over a limited area in the extreme western part of the State. It is cut by the Potomac and Youghiogheny rivers and abounds in smaller streams. Springs are also common in this region. The surface waters are so abundant that the relatively small population depends largely on natural water supplies, very few wells being sunk except in the river bottoms, where good water is obtained at slight depth. Such wells as have been drilled, however, have generally procured considerable water from the shales and sandstones of the Carboniferous and Devonian. Several wells in the synclines or basins yield flowing water.

Appalachian Mountains.-There are a few wells in the river bottoms and there is an occasional shallow rock well in the limestone or shale valleys in the Appalachian Mountain belt, but deep wells are lacking, springs constituting almost the only source of natural supply. Cisterns are sometimes used.

Piedmont Plateau.-The surface of the Piedmont Plateau is here, as elsewhere, made up of more or less deeply weathered and jointed crystalline rocks. These contain considerable water in the aggregate, many shallow wells deriving their supplies from their weathered upper portions, while other wells obtain water from joint fissures at greater depths. The occurrence or nonoccurrence of water at a given point can seldom be predicted, however, because of the great variability of the governing factors. The largest supplies are obtained from these rocks near the cities of Baltimore and Washington, each of which is discussed separately. 
Coastal Plain.--The Coastal Plain region in eastern Maryland presents the usual general structural relations, but certain local features are conspicuous. The Raritan formation merges into the underlying Potomac formation; the upper marl of the marine Cretaceous thins and changes to more clayey beds, and only the middle and lower members continue southward, where they have been designated the Severn formation; the Pamunkey greensand marl comes in, and the plateau areas capped by the Lafayette formation become characteristic features. The formations are as follows:

Coastal Plain formations in Maryland.

\begin{tabular}{|c|c|c|}
\hline Formation. & Characteristics. & Age. \\
\hline Columbia . & Loams, sands, and gravels on terraces & Quaternary. \\
\hline Lafayette & Gravel, sands, and loams $\ldots . . . . .$. & Pliocene? \\
\hline Chesapeake - & Sands, clays, infusorial earth, and marl. & Miocene. \\
\hline Pamunkey .. & Glauconitic marls and sands ... & Eocene. \\
\hline Severn ..... & Black argillaceous, carbonaceous sands & Cretaceous. \\
\hline Magothy - - & White sands and brown sandstones.... & Cretaceous. \\
\hline Potomac ....... & Clay, sands, and gravels ................ & Early Cretaceous. \\
\hline
\end{tabular}

In the following table is given a list of the more important localities obtaining deep or artesian waters. Baltimore wells are not given, but are considered on a subsequent page:

Statistics of deep-well localities in Maryland.

\begin{tabular}{|c|c|c|c|c|c|}
\hline \multirow{2}{*}{ Locality. } & \multicolumn{2}{|c|}{ Range of depth. } & \multicolumn{2}{|c|}{$\begin{array}{l}\text { Range of capacity } \\
\text { per minute. }\end{array}$} & \multirow{2}{*}{ Geologic horizon of water. } \\
\hline & From- & To- & From- & To- & \\
\hline & Feet. & Feet. & Gallons. & Gallons. & \\
\hline Agricultural Collegc .. & & 150 & & 5 & Basal Potomac. \\
\hline Annapolis ........... & ......... & 201 & $\cdots$ & ........... & Magothy. \\
\hline Bay Ridge............. & $\ldots \ldots$ & 470 & $\ldots \ldots$ & 20 & Mid-Potomac. \\
\hline Bowie...$\ldots \ldots \ldots \ldots$ & $\ldots \ldots$ & 384 & $\mathbf{0}$ & $\therefore \ldots \ldots \ldots$ & In Potomac. \\
\hline 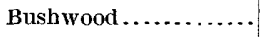 & & 287 & & |............ & Low in Pamunkey. \\
\hline Cambridge, 6 wells.... & ........ & 370 & 160 & each, 250 & Basal Chesapeake. \\
\hline Chapel Point ...... & $\ldots$ & 237 & & & Basal Pamunkey. \\
\hline Claiborne ............ & 100 & 440 & & Many & Magothy, in Pamunkey. \\
\hline Cornfield Harbor ..... & $\ldots \ldots \ldots$ & 360 & 1 & $\ldots$ & Basal Chesapeake. \\
\hline On farm $\ldots \ldots \ldots \ldots$. & 240 & 370 & & $\ldots \ldots \ldots$ & Chesapeake, Basal Chesapeake. \\
\hline Crisfield .............. & 1,018 & 1,090 & 40 & 200 & Magothy, Potomac. \\
\hline Denton ............... & $\ldots \ldots$ & 359 & $\ldots \ldots \ldots$ & 30 & \\
\hline Easton, 6 wells. & 102 & 600 & $\mathbf{0}$ & each, 75 & $\left\{\begin{array}{l}\text { Low in Chesapeake, Into Pamunkey, } \\
\text { Low in Severn? }\end{array}\right.$ \\
\hline Federalsburg ....... & & 234 & & 20 & In Chesapeake. \\
\hline Indian Head .. & & $463 \frac{1}{2}$ & & $11 \frac{1}{2}$ & In Potomac. \\
\hline Laurel................ & . & $148 \frac{1}{2}$ & $\ldots$ & 10 & Basal Potomac. \\
\hline Le Compt's store ...... & & 358 & $\ldots$. & 4 & Basal Chesapeake. \\
\hline Leonardtown ........... & & 300 & & 2 & Do. \\
\hline Marlboro ......... & & 222 & & 25 & Magothy? \\
\hline
\end{tabular}


Statisties of deep-well localities in Maryland-Continued.

\begin{tabular}{|c|c|c|c|c|c|}
\hline \multirow{2}{*}{ Locality. } & \multicolumn{2}{|c|}{ Range of depth. } & \multicolumn{2}{|c|}{$\begin{array}{l}\text { Range of capacity } \\
\text { per minute. }\end{array}$} & \multirow{2}{*}{ Geologic horizon of water. } \\
\hline & From- & To- & From- & To- & \\
\hline $\begin{array}{l}\text { MilesRiver Neck ("An- } \\
\text { chorage") }\end{array}$ & 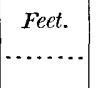 & $\begin{array}{r}\text { Feet. } \\
265\end{array}$ & $\begin{array}{c}\text { Gallons. } \\
. . . . . . . . . .\end{array}$ & $\begin{array}{r}\text { Gallons. } \\
15\end{array}$ & In Pamunkey. \\
\hline $\begin{array}{l}\text { MilesRiverNeck (Long } \\
\text { Point) }\end{array}$ & & 195 & & 5 & Basal Chesapeake. \\
\hline Nanjemoy (Landing)... & & 175 & & 1 & Basal Pamunkey. \\
\hline Oakley $\ldots . . . \ldots \ldots \ldots$ & $\cdots$ & 305 & & 7 & Low in Pamunkey. \\
\hline ocean City ............ & & 256 & & 130 & High in Chesapeake. \\
\hline $\begin{array}{l}\text { Patuxent River, at B. } \\
\text { \& P. R. R. }\end{array}$ & & 152 & & 20 & Basal Potomac? \\
\hline Piney Point ........... & & 270 & & $5(?)$ & Basal Chesapeake. \\
\hline Rousby on Patuxent .. & $\cdots$ & 240 & & Many. & Do. \\
\hline $\begin{array}{l}\text { Rock Point, Charles } \\
\text { County. }\end{array}$ & 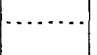 & 254 & & 3 & Do. \\
\hline $\begin{array}{l}\text { St. George Island, } 25 \\
\text { wells. }\end{array}$ & ......... & 270 & 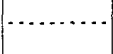 & each, 2-5 & Do. \\
\hline $\begin{array}{l}\text { St. Inigoes, } 10 \text { wells, } \\
\text { "Jutland." }\end{array}$ & & 365 & & 1 & Do. \\
\hline Salisbury ............. & ........ & 101 & n..... & 350 & High in Chesapeake. \\
\hline $\begin{array}{l}\text { Solomons Island, } 2 \\
\text { wells. }\end{array}$ & 252 & 258 & 10 & each, 150 & Basal Chesapeake. \\
\hline Tilghman Island ....... & & 400 & ...... & Many. & Magothy? \\
\hline $\begin{array}{l}\text { Tunis Mills, on Miles } \\
\text { River Neck. }\end{array}$ & & 430 & Flows, 6 & Pumps, 100 & Do. \\
\hline
\end{tabular}

\section{WATER HORIZONS.}

It is now known that the greater part of the entire Coastal Plain region of Maryland is underlain by several horizons of water-bearing beds. The distribution of wells and water horizons is represented in the cross sections of Pl. VII.

The gravels and sands of the basal beds of the Potomac formation that lie on or near the floor of crystalline rocks are the principal sources of water for wells sunk in the western portion of the Coastal Plain. How far southeastward this water horizon may extend has not been determined, but probably it will yield water in many areas nearly to the Atlantic coast. To the east and south the dip of the Potomac horizon carries it to a great depth, but there are several strata of water in higher beds in the Potomac, and in other formations at more moderate depths. The easternmost successful wells which have reached the base of the Potomac formation are those in the southeastern portion of the Baltimore region, in the District of Columbia, and at Middletown, in Delaware, all of which are only a few miles from the outcrop of the formation, so that the eastern extension of the basal Potomac waters is not known over a very great breadth of territory. The failure of a well at Sparrow Point to find water in the basal beds indicates also that the sheet of water is not general at this horizon. 


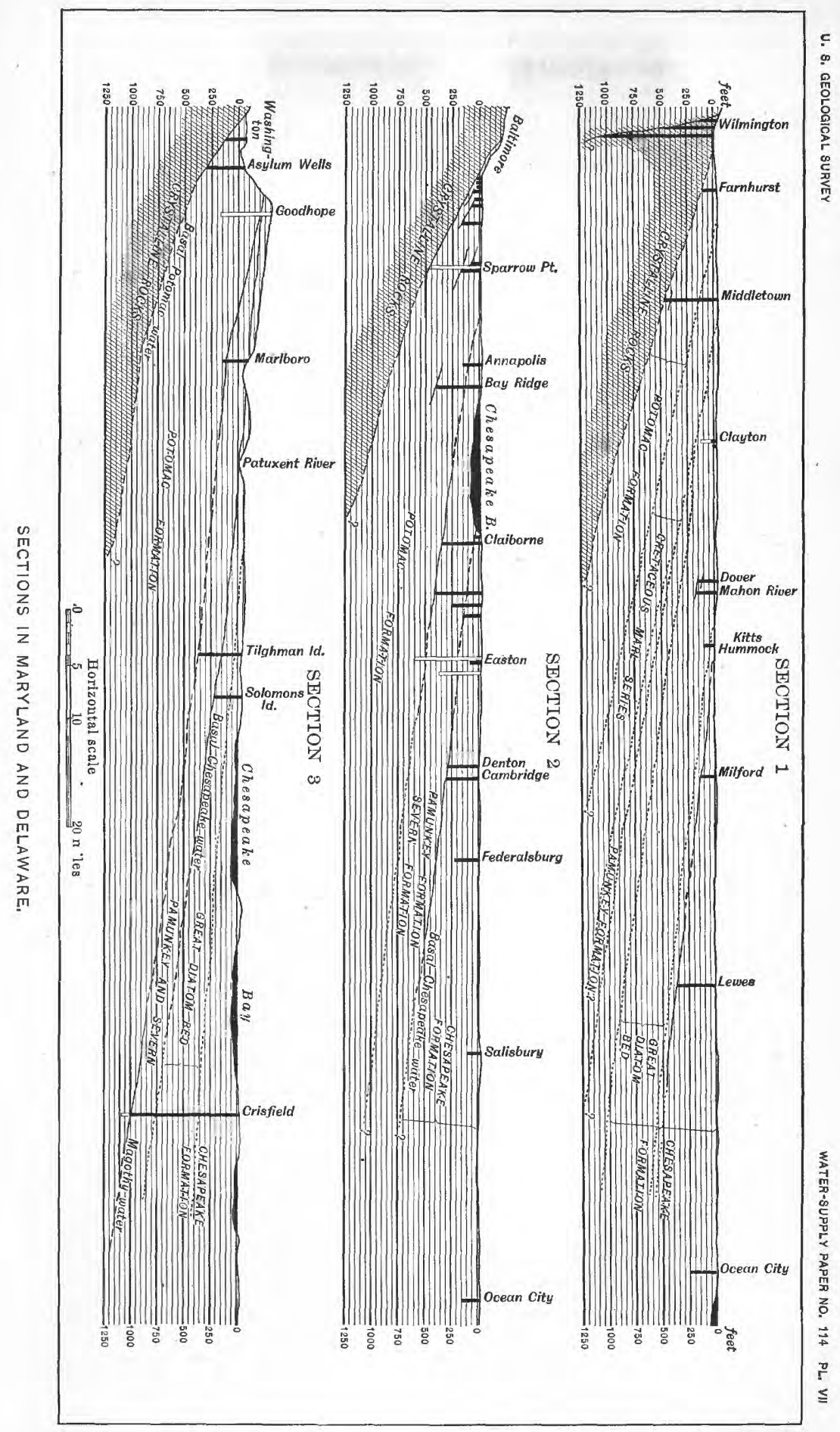




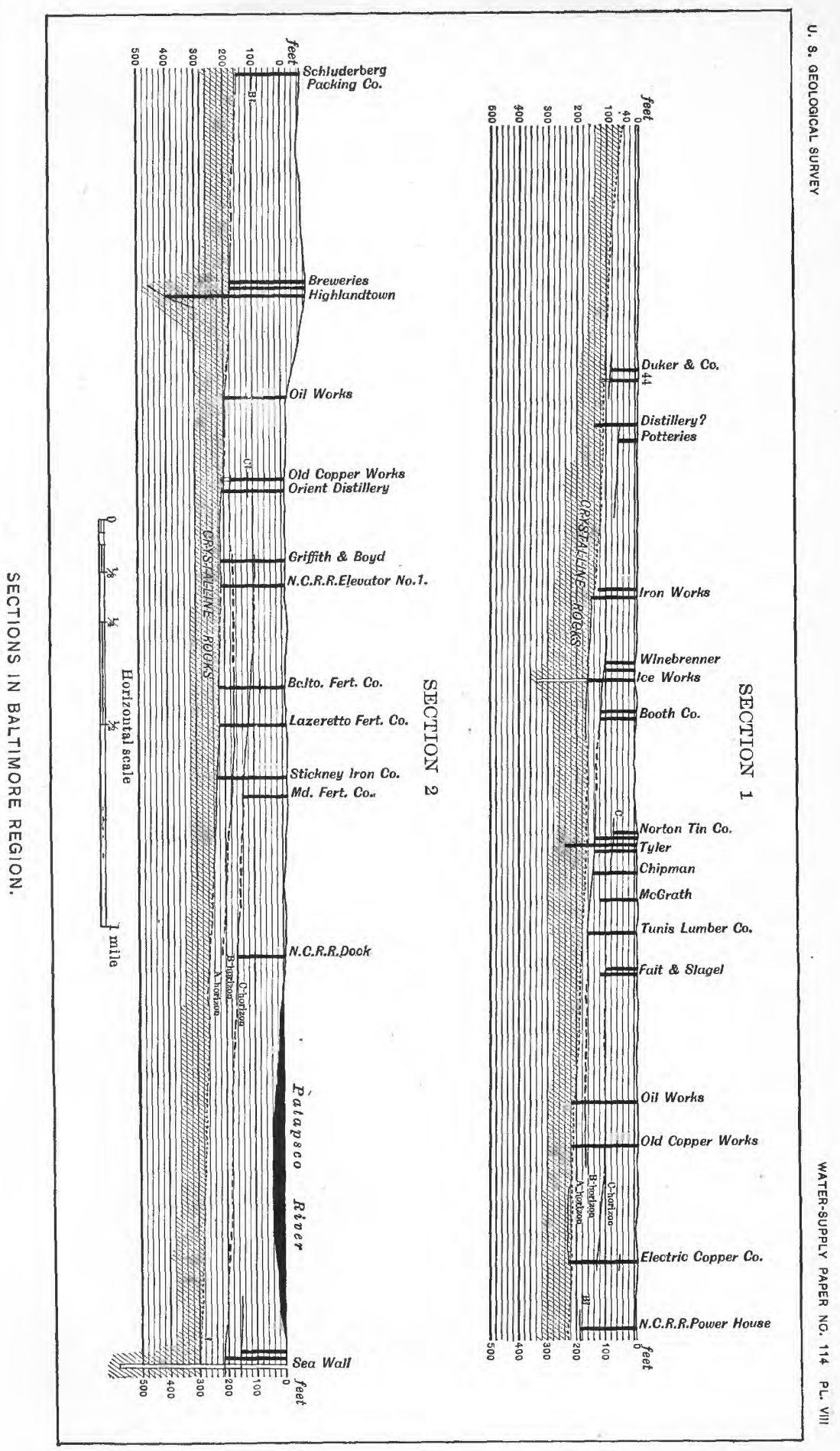


The water horizons lying at various distances above the basal beds. but within the Potomac formation, have been extensively explored in the vicinity of Washington and Baltimore, where they appear to be widespread and satisfactorily productive. They havealso been reached in a Marlboro well at a depth of 216 feet, and in a well at Indian Head at 459 feet. A well at Bowie found no satisfactory supply of water to within about 200 feet of the base of the formation, nor was a well on Spesutie Island a success, though it appears to have penetrated the Potomac beds to a considerable distance. The sands of the Magothy formation, which underlie the Potomac, appear to be water bearers over a wide area on the Eastern Shore of Maryland, as is probably indicated by wells at Claiborne, Tilghman Island, and Crisfield, and possibly also at Tunis Mills. They underlie the central area of the Western Shore southeast of a line from Bowie to the mouth of the Patapsco River, but do not appear to yield water in Marlboro, Annapolis, and Bay Ridge wells. A boring to 600 feet at Easton, unfortunately, probably did not thoroughly test this horizon, otherwise we might have had some important evidence for that portion of the Eastern Shore region. A 265-foot well on Miles River Neck appears to draw its water from a horizon in the Pamunkey formation, but this well is the only indication of a water horizon in these formations in the Eastern Shore region. In wells at Colonial Beach, Va., and at Nanjemoy, Chapel Point, and Rock Point, in Charles County, the basal Pamunkey beds yield water which probably underlies much of southern Maryland southeast of a line from Herring Bay to Liverpool Point.

The basal Chesapeake water horizon, which is well explored in Virginia, yields water over a wide area in the southern counties of the Western Shore at depths from 200 to 300 feet, as in wells at Solomons Island, Leonardtown, Piney Point, St. Inigoes, and St. Georges Island. At Cornfield Harbor it is 365 feet. This horizon also furnishes large water supplies at Denton, Cambridge, and Le Compt's store, and possibly in a well 195 feet deep on Miles River Neck, on the Eastern Shore. It was not found at Crisfield, nor in a deeper boring at Easton, although the associated sandstone bed was reported at Easton. The higher Chesapeake horizons are important in New Jersey and Delaware, and, although not extensively tested in southern Maryland, they probably underlie a considerable area of the Eastern Shore. At Easton the large water supply in wells 100 feet deep is derived from a horizon in the Chesapeake formation about 150 feet above its base, and the Federalsburg water, which lies at a depth of 234 feet, is either at the same horizon or at one not a great distance above. The small showing of water at 160 feet at Leonardtown appears to be a local occurrence, for it was not reported in other wells to the east. Unsatisfactory water was obtained at Salisbury from a much higher horizon, 
and the flow of fine water at Ocean City is from a still higher horizon of the Chesapeake formation. In the wells at and near Cambridge and at Crisfield no waters were reported above the basal Chesapeake beds; so we must conclude that the higher waters do not extend in that direction.

\section{BALTIMORE DISTRICT.}

\section{GEOLOGY.}

Baltimore lies in the zone in which the crystalline rocks emerge from beneath the Coastal Plain deposits. Although in greater part it is built on the Potomac formation, the depressions of Jones and Gwynns falls are excavated to the crystalline rocks, and these rocks rise rapidly to constitute the surface in the region north and west of the city. The Potomac formation consists of its usual materials, in which predominate clays of various colors and fine sands. Toward its base there are beds of coarse sands and gravels, and at the base an almost general occurrence of these materials, lying on a floor of crystalline rocks. Some features and relations of these basal beds are shown in PI. VIII. The coarse materials contain widely extended sheets of water, which have been tapped by many well borings of moderate depth. The rock floor slopes rather steeply eastward, at a rate averaging about 65 feet per mile, but the rate appears to increase locally to 100 feet along by the Basin. The basal gravels pass beneath tide water along a line extending from the lower Baltimore and Obio Railroad bridge over Gwynns Falls to the Fayette Street Bridge over Jones Falls, and thence due east-northeastward. The principal water supplies are found south of this line, for in the area to the north the waters are free to flow laterally into the depressions of Jones and Gwynns falls. The basal gravels emerge in the northern portion of the city, although in some areas they are overlain by a thin cap of gravels and loams of earlier (Columbia) age. They cap the Druid Hill Park region, the ridges for some distance out Charles street, Roland avenue, and York, Harford, and Belair roads, and the high region about Catonsville. In these outlying extensions the basal gravels constitute a capping on the crystalline rocks which averages from 10 to 30 feet in thickness. The principal structural relations are shown in the sections on PI. VIII. On Patapsco River Neck the Potomac formation rapidly thickens as the crystalline rock floor descends to the east, and at Sparrow Point its thickness was found to be 500 feet. The higher ridge which extends along the northern portion of this neck is capped by a thin mantle of earlier Columbia gravels and loams, and the lower terraces consist of later Columbia loams and sands, with some gravel in the lower beds. These formations, however, are not involved in the question of the deeper water supply. 
The crystalline rocks present considerable variety of materials, but gneiss and granite, or "gray stone," and "nigger head," or gabbro, are the most conspicuous varieties. They are all considerably fissured and often deeply decomposed along fissures or veins of moderate width and extent. The fissures or veins are usually nearly vertical and extend from northeast to southwest. They are water-bearers in greater or less measure, but their distribution and extent have not been determined, except in the case of the one along Belair road, which has been tested for a short distance.

\section{WATER HORIZONS AND WELL PROSPECTS.}

Canton.-The wells in Canton indicate the presence of several widely extended sheets of water-bearing gravels, the upper layers of which are interbedded between sheets of clay and fine sand, the lower bed lying on the floor of crystalline rocks. The dip is to the southeast at rate of about 60 feet per mile. In PI. VIII the first section lies along Clinton street from Highlandtown to Thirteenth avenue and across Patapsco River to Seawall. The three principal water horizons are lettered A, B, and C. They occur from the bed rock up at intervals that average 40 feet.

There are several wells north of Canton, at Highlandtown, which yield large water supplies. At the National Brewery there are two wells to 240 and 450 feet, and at Gunther's brewery two wells to 207 and 208 feet. The waters at 207 and 240 feet are probably in basal Potomac beds, or at Horizon A, as shown in section 1, Pl. VIII. At Schluderberg's packing house a well yields water at 135, 160, and 210 feet, and the 160-foot or third horizon was tested to 150 gallons a minute. The basal beds of the Potomac formation probably carry the water found at 210 feet.

East Baltimore, from Canton to the Basin.-There are only a few wells in the vicinity of Jones Falls, and they are not very successful, but from the foot of Patuxent street to Ann street there are 25 wells, nearly all of which are large producers of excellent water. The average depth is between 80 and 120 feet, and the principal water horizon is. $\mathrm{B}$ of the Canton region, but $\mathrm{A}$ and $\mathrm{C}$ also are found. Section 2 of Pl. VIII illustrates the principal relations.

The large water supply found in the basal Potomac beds, Horizon A, appears to extend to the north and west, but it was not reported half a mile southeast. The greater number of the wells in this district find abundance of water in Horizon B, about 40 feet above the basal beds.

What appear to be the sea horizons of the Canton region yield water in places.

In the region immediately adjoining Jones Falls and for some distance to the west on the north side of the Basin deep wells do not yield 
satisfactory water supplies on account of the proximity of the basal and lower Potomac beds to the surface. Several wells have penetrated the crystalline rocks and found a fair supply of satisfactory water.

Region between the Basin and the harbor and Middle Branch.-There are several wells along the north side of Locust Point from the Basin to Fort McHenry, which yield satisfactory water supplies from the Potomac horizons.

Probably Horizons B and C underlie all of the Locust Point region, and Horizon A, in the basal beds, may possibly occur at some localities southeast of the Federal Hill region.

On the Ferry Bar peninsula there are a few widely scattered wells, which, however, indicate that the favorable conditions in Canton and on Locust Point continue to the west, and that abundant waters may be obtained in Horizons $\mathrm{C}, \mathrm{B}$, and $\mathrm{A}$. The shallower waters are unsatisfactory in quality, but the deeper waters give no scale in boilers and occur in largé amounts.

Between the Basin and Ridgely Cove a number of attempts have been made to obtain water from the crystalline rocks, with varying degrees of success.

Region from Brooklyn to Curtis Bay.-The successful group of wells at Seawall and at South Baltimore (Curtis Bay) indicates a wide and general extension of the Potomac waters under the Curtis Bay-Patapsco River peninsula. The Seawall water at 217 feet appears to represent Horizon C. The 562-foot boring at Seawall no doubt demonstrates the absence of water in the basal Potomac, or Horizon A, in that vicinity, and also in the underlying crystalline rocks.

Region southeast of Canton to Sparrow Point.--The wells of St. Helena, Dundalk, and Sparrow Point are included under this heading. Their relations are shown in section 2, Pl. VIII. The wells at St. Helena are probably in Horizon C, and the water at 230 feet at Dundalk is thought to be in Horizon B, which probably would have been found at 200 feet at St. Helena. The 120 -foot water at Dundalk is possibly the deepest water of Sparrow Point.

The Sparrow Point wells are a most satisfactory group of water producers. Their principal supply is obtained at a depth of 125 feet from a horizon high in the Potomac formation, for a well sunk to a depth of 495 feet just reached the granite bed rock. In this deep well no water was found below 210 feet, which indicates that the lower water horizons do not extend far eastward in this region. The one well which draws 100 gallons a minute from a depth of 210 feet obtains its supply from a horizon which can not be definitely correlated with those of wells farther northwest.

Northeast Baltimore. - Several breweries in this section of the city have deep wells, some of which yield satisfactory water supplies. They all penetrate the crystalline rocks and obtain water from fissures 
or decomposed portions of these rocks in fair supply, but when wells were sunk to 315 and 400 feet at the Bauernscbmidt brewery, a block southwest, the supply at once diminished to a very small amount. The well at the Brehm brewery, which is some distance east of the Belair road and several squares beyond North avenue, was sunk in the rock to a depth of 1,300 feet without finding water, but it is considerably east of the line of the other wells.

The Darley Park Brewery well, on the Harford road, three squares north of North avenue, is west of the Belair-Gay street line of wells. The waters from these wells differ considerably in character, but in greater part they are satisfactory for boilers and drinking, although in some cases the water is too ferruginous for general use.

Western part of Baltimore.-Except the well at the Lipp Soap Works, at Hollins street and Calverton Road, no specific data for borings in the western part of Baltimore are at hand. The soap works wells are in crystalline rocks and reach a vein or fissure whicb yields a good supply of water of excellent quality.

\section{PRINCIPAL PUBLICATIONS.}

Mineral springs of the United States, by A. C. Peale: Bull. U. S. Geol. Survey No. 32, pp. 51-53.

Artesian-well prospects in the Atlantic Coastal Plain region, by N. H. Darton: Bull. U. S. Geol. Survey No. 138, pp. 124-155.

Preliminary list of deep borings in the United States, pt. 1, by N. H. Darton: Water-Supply and Irrig. Paper U. S. Geol. Survey No. 57,p. 50.

Water resources of the Accident and Grantsville quadrangles, Maryland, by G. C. Martin: Water-Supply and Irrig. Paper U. S. Geol. Survey No. 110, 1905, pp. 168-170.

Water resources of the Frostburg and Flintstone quadrangles, Maryland and West Virginia, by G. C. Martin: Water-Supply and Irrig. Paper U. S. Geol. Survey No. 110, 1905, pp. 171-173.

Description of the Fredericksburg quadrangle, Maryland and Virginia, by N. H. Darton: Geol. Atlas U. S., folio 13, U. S. Geol. Survey.

Description of the Nomini quadrangle, Maryland and Virginia, by N. H. Darton: Geol. Atlas U. S., folio 23, U. S. Geol. Survey.

Description of the Washington quadrangle, Maryland, District of Columbia, and Virginia, by N. H. Darton and A. Keith: Geol. Atlas U. S., folio 70, U. S. Geol. Survey. 


\section{DISTRICT OF COLUMBIA.}

By N. H. Darton and M. L. Fuller.

\section{GEOLOGY.}

The District of Columbia extends across the zone in which the crystalline rocks emerge from beneath the Coastal Plain deposits and rise into the Piedmont Plateau to the west. The contact line crosses the Potomac River at Washington, passes through the western portion of the city, and extends northward along the east side of Rock Creek Valley. The formation that lies on the crystalline rocks is the Potomac, which consists mainly of water-bearing sands and gravels below and of clay and fine sands above. The Potomac formation has in all a thickness of about 700 feet, and outcrops in a belt from 7 to 8 miles wide, which extends eastward high up the slopes on the east side of Anacostia River. In these slopes it is surmounted by younger formations, consisting of a succession of the thin western edges of the dark sandy clays of the Severn formation, the impure marl of the Pamunkey, the gray clays of the Chesapeake, and the gravels of the Lafayette. Washington is situated on a series of broad, low terraces cut in Potomac sands and clays and across the edge of this formation into the crystalline rocks.

This series of terraces and its extension along all the lower land of the District is capped by from 20 to 35 feet of gravelly sands and loams of the Columbia formation. In the three sections in PI. IX a fairly clear representation is given of the structure of the Washington region. It is in Good Hope Hill that the Potomac formation passes under the Severn, Pamunkey, Chesapeake, and Lafayette formations, as shown in section 2, but there are also small outlying areas of the Chesapeake and Lafayette formations on the high lands of Soldiers' Home Park and the ridge which extends to Tenley.

\section{WATER HORIZONS AND PROSPECTS.}

Waters of the crystalline rocks.-Under this head are included the waters of the consolidated rocks of the Piedmont Plateau portion of the District. These rocks comprise granite-gneiss, biotite-granite, diorite, etc., and are generally deeply weathered and cut by numerous 
Wh. A. 2and

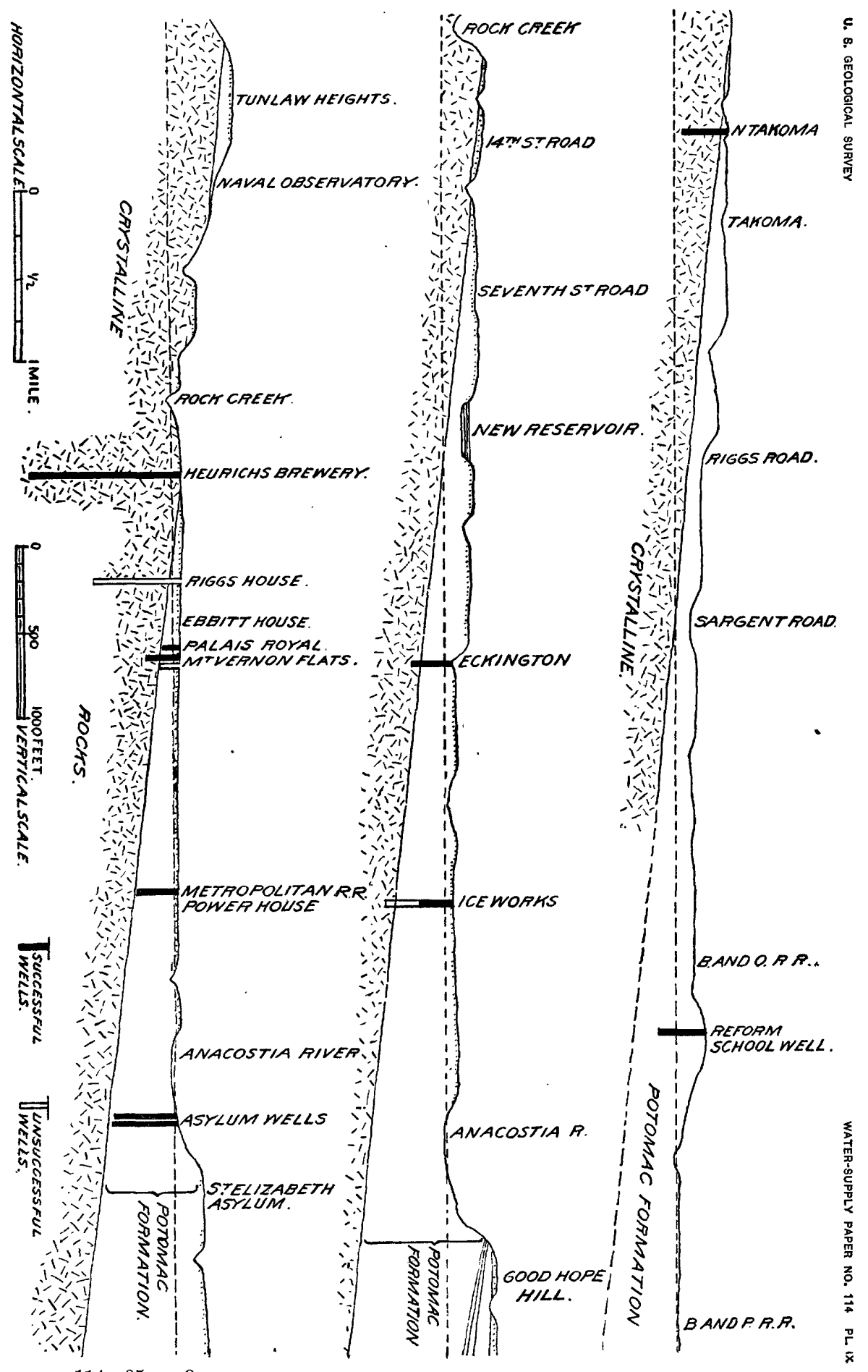

IRR 114-05-9 
joints. The disintegrated nature of the outcrops is favorable to the absorption of considerable quantities of water and the broken-up rock acts as a filter. In general, the area of the consolidated rocks is relatively thinly settled and little demand is made on it for water supplies, except by shallow wells. The few deep wells that have been put down, however, show that moderate amounts of good water can frequently be obtained, although, because of variations in the density of the rock and in the number of joint fissures, the conditions are far from constant.

The surface of the consolidated rocks slopes southeastward from Rock Creek, where it is exposed at an elevation of 200 feet, at an average rate of 110 feet to the mile. It lies at a depth of about 100 feet below tide level in the center of the District and of about 600 feet at the southeastern boundary. The crystalline rocks are not depended upon as a source of water east of Rock Creek because of the greater quantities that are found in the sedimentary beds that overlie them in this region.

Waters of the sedimentary rocks.-All of the sedimentary formations carry more or less water, but, except in the case of the Potomac, the flows are small and the quality is not the best. This is especially true in the isolated areas capping the hills of crystalline rocks, even the Potomac frequently failing in such localities.

The Potomac is the principal water-bearing formation of the area; it constitutes the surface material over most of the Coastal Plain portion of the District, having a catchment area from 6 to 8 miles in width. Its base rests on the crystalline rocks, dipping southeastward with the latter. Its total thickness, as pointed out, is about 700 feet.

The deeper-seated underground waters have been tapped by a sufficiently large number of wells in the District to demonstrate the almost general extension of water-bearing beds in the basal and lower bed of the Potomac formation, and there is often a fair prospect for finding water in the crystalline rocks. The wells that did not find a satisfactory water supply in the basal Potomac beds are at the Ice Works at a depth of 360 feet, and at the Mount Vernon Apartment House at 133 feet. On the other hand, the St. Elizabeth, Metropolitan Railroad power house, Palais Royal, Eckington, Washington Brewery, and National Capitol Brewery wells obtain large supplies from that horizon. In surface outcrops the basal Potomac beds are usually coarse sands and gravels, which are filled with water, but there are some local areas in which there is a clay matrix, or even pure clay, extending down to the crystalline floor. This was found to be the case at the Mount Vernon Apartment House, while at the Palais Royal, three squares southwest, the basal beds were coarse sands and gravels containing much water. In the 380 -foot well at the Ice Works coarse 
bisal beds were found, but they contain no large supply of water. This leads to the conclusion that the waters are in part choked off toward the north by a local area of clayey beds which does not influence the wells at the breweries near by.

Besides the basal sands and gravels of the Potomac there are beds of sand or gravel at several other horizons, especially near the top. Although of somewhat uncertain persistence and character they are so numerous that good flows can generally be obtained at or even considerably above sea level. As these beds occur in the District only near its southeastern border they are not here important sources of water, the underground water supply of the District being derived, as stated, mainly from the lower beds.

In general the dip of the Potomac formation corresponds roughly with the slope of the surface of the underlying crystalline rocks, decreasing from an elevation of 200 feet above sea level just east of the Zoological Park to sea level in the vicinity of New Hampshire avenue, 200 feet below sea level at the Capitol, 300 feet at Lincoln Park, 400 feet near Anacostia River, and 600 feet at the District line; hence there is a constant increase southeastward in the depths to which wells must be sunk to the water-bearing beds.

In general it may be said that the prospects are good for obtaining supplies from the basal beds of the Potomac, while there is always an additional chance of finding water in the overlying beds, as at the ice works. Notwithstanding the density of the population of almost the entire catchment area in the District, the organic impurities of the water are largely oxidized and removed in consequence of the natural filtration through the soil and sands, so that the supply from deep wells is usually satisfactory as regards purity.

Mineral springs.-Springs are fairly numerous in the District of Columbia, but in general consist only of small seeps from the disintegrated crystalline rocks or from the sandy portions of the Coastal Plain formations. A number have been developed, however, and water to the amount of 212,100 gallons, with a value of $\$ 12,105$, was placed on the market in 1902. ${ }^{a}$ These are listed below:

Columbia Natural Lithia Spring, Washington.

Crystal Spring, Washington.

Gitchie Crystal Spring, Benning.

Laurelwood Spring, Mount Pleasant.

\section{PRINCIPAL PUBLICATIONS.}

Artesian-well prospects of the Atlantic Coastal Plain region, by N. H. Darton: Bull. U. S. Geol. Survey No. 138, pp. 155-161.

Description of the Washington, D. C., quadrangles, by N. H. Darton and A. Keith: Geol. Atlas of U. S., folio 70, U. S. Geol. Survey. 


\section{VIRGINIA.}

By N. H. Darton and M. L. Fuller.

PHYSIOGRAPHIC DIVISIONS.

There are four well-defined geologic and topographic belts in Virginia: (1) The Coastal Plain, (2) the Piedmont Plateau, (3) the Appalachian Mountain belt, and (4) the Cumberland Plateau. The first three are prolongations of the belts of the same name in Maryland, with which they agree in character. The fourth corresponds in a general way with the Allegheny Plateau of Pennsylvania and Maryland, although its surface was not produced at the same geologic period.

\section{GEOLOGY AND WATER HORIZONS.}

COASTAL PLAIN.

GEOLOGY.

The Coastal Plain region of Virginia lies east of a line which passes through Alexandria, Fredericksburg, Bothwell, Richmond, Petersburg, and Emporia, comprising an area of about 9,500 square miles. This district is traversed from northwest to southeast by a series of great rivers, which divide it into a succession of long ridges. These ridges are remnants of a plateau surface which slopes from an altitude of from 300 to 200 feet at the western margin of the Coastal Plain to an altitude of about 100 feet on its eastern margin. The larger rivers are tidal estuaries that occupy low valleys and meander through wide terrace plains. Chesapeake Bay is widely bordered by these interstream terraces, while the Eastern Shore of Virginia, which lies east of the bay, is a low plain, as is also the wide area which lies between Dismal Swamp and the Atlantic Ocean.

The geologic structure of the region is in general similar to that of eastern Maryland, but there are certain differences in the stratigraphy. In the outcrop zone the Potomac formation becomes predominantly sandy and the Severn and Magothy sands are absent, so that the Pamunkey marls lie directly on the surface of the Potomac beds. Far eastward, under the bay and the Eastern Shore, there is probably 
presented the same sequence that is found in Maryland. The Chesapeake formation extends farther westward in southern Virginia and often overlaps on the crystalline rocks. In the sections, Pl. X, there are shown the general structural relations in Virginia so far as they are known. The Coastal Plain formations that outcrop in the State are as follows:

Coastal Plain formations in Virginia.

\begin{tabular}{|c|c|c|}
\hline Formation. & Characteristics. & Age. \\
\hline Columbia.. & Loams, sands, and gravels in terraces .. & Pleistocene. \\
\hline Lafayette .... & Orange sands, loams, and gravels ...... & Pliocene? \\
\hline Chesapeake... & Clays, sands, infusorial earth, and marl. & Miocene. \\
\hline Pamunkey..... & Glauconitic marls and sands..... & Eocene. \\
\hline Potomac..... & Sands, sandstone, and clays. & Early Cretaceous. \\
\hline
\end{tabular}

WATER HORIZONS.

The greater part, if not all, of the Coastal Plain region of Virginia is underlain by water-bearing strata, of which, to the east, there are several horizons. The failures to obtain the higher water in some of the wells near the bay indicate that in this area at least there are no good water supplies in the higher horizons, but the waters of the lower horizons have not yet been fully developed. The success of the new well at Fort Monroe definitely proves the existence of one of these. The failure of a single well, as at North End Point, does not always disprove the existence of a water horizon, for in many instances water has been passed unnoticed, or willfully, by well borers.

The principal water horizons in eastern Virginia are the Chesapeake, the Pamunkey, and the Potomac.

Potomac.-There is more or less water in all of the coarser sand beds of the Potomac formation, but the principal supplies may be expected from the sands and gravels of the basal members lying on the basement floor of crystalline rocks. This horizon has yielded much water about Washington, Alexandria, Quantico, and Walkerton. It is probably a strong water-bearer throughout a wide extent. Its general relations are shown in $\mathrm{Pl}$. X.

Water occurs at various horizons in the Potomac formation above the basal beds in sands interbedded among the clays. This water is an important source of supply in the District of Columbia and at Barrow, near Quantico, but elsewhere it has not been fully tested.

Pamunkey. - The coarse gravel and sand at the base of this formation appears to be a water-bearer throughout a considerable area, furnishing supplies at Naylors Wharf, Chapel Point, Md., Colonial Beach, Lester Manor, and Whitehouse. 


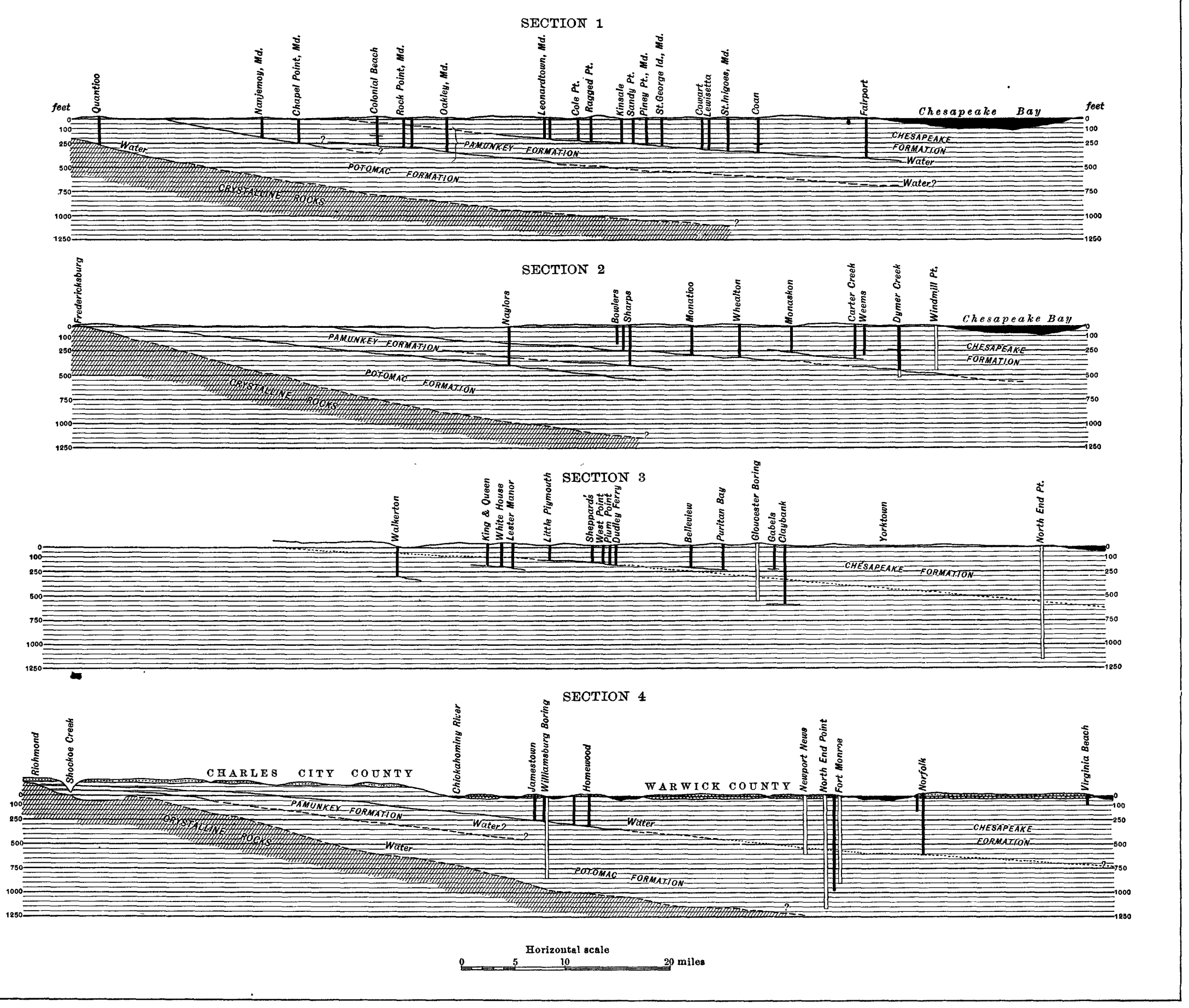

SECTIONS IN EASTERN VIRGINIA. 
The meager supply of water in the Clay Bank well and the failure of the deeper borings at Williamsburg and Gloucester probably indicate the eastern limits of the horizon as a water-bearer. It may extend under all of the region south of the James River, although none of the wells appear to have been hored sufficiently deep to reach it. It is to be expected that toward the east the materials at this horizon finally become too fine-grained to carry water, and the eastern limit of conditions favorable for water bearing appears to be at Clay Bank, on York River.

Water also occurs in sands in the Pamunkey formation about 90 feet above its base, as is indicated by the water at 160 feet at Colonial Beach, and at 275 to 325 feet at Naylors Wharf; but as it has not been further explored by other wells, its extent can not be discussed.

Chesapeake.-Lying between the clays, marls, and fine sands of the Chesapeake formation and the top of the Pamunkey formation there is a series of sands and gravels which may be regarded as the basal bed of the Chesapeake formation. Toward the east this series contains thin interstratified rock strata, which do not appear in the surface outcrops. In this series, and in another similar one not far above, there is a large volume of water, at a horizon or horizons which appear to be of wide extent in eastern Virginia. These waters have been explored by many wells and have been found to underlie a belt of country about 20 miles wide lying east of a nearly straight line extending from Mathias Point, on the Potomac River, to Emporia, on the Atlantic Coast Line Railroad.

- Basal Chesapeake waters were apparently absent in the North End Point, Fort Monroe, Dendron, Clay Bank, and Gloucester wells. The wells at Crisfield, Md., found no appreciable supply of water in the basal Chesapeake beds.

There are several higher water horizons in the Chesapeake formation, and it is believed that certain wells at Franklin, Zuni, Bowlers Wharf, and Mount Carmel draw water from Chesapeake beds that lie about 100 feet above the base of the formation.

WELLS.

The occurrence of the underground waters is well brought out by the list of some of the more important wells of the Coastal Plain presented in the following table. It will be noted that the supply per minute and the bed from which the water is obtained is indicated in each case. 
Partial list of deep wells.

\begin{tabular}{|c|c|c|c|c|c|c|}
\hline Location. & Depth. & Size. & $\begin{array}{l}\text { Capacity per } \\
\text { minute. }\end{array}$ & $\begin{array}{c}\text { Height } \\
\text { to which } \\
\text { water } \\
\text { rises. } a\end{array}$ & Horizon. & Remarks. \\
\hline & Feet. & $I n$ & Gallons. & Feet. & & \\
\hline Alexandria Brewery. & 430 & 8 & 90 & & Basal Potomac... & Soft water. \\
\hline $\begin{array}{l}\text { Alexandria Ice } \\
\text { Works. }\end{array}$ & 401 & 8 & 20 & -12 & ….... & $\begin{array}{l}\text { Poor water at } 300 \\
\text { feet. }\end{array}$ \\
\hline Arringdale, 2 wells.. & 75 & & Flows 10 & +10 & & $\begin{array}{l}\text { Slightly alkaline } \\
\text { water. }\end{array}$ \\
\hline Ashland ... & 79 & $1 \frac{1}{2}$ & Many. & $-4 \frac{1}{2}$ & Granite? & \\
\hline Do.. & 100 & 4 & Many. & $\ldots$. & Granite ... & \\
\hline Barrow ... & 195 & & Many. & .... & In Potomac.. & $\begin{array}{l}\text { Now ater below } 143 \\
\text { feet. }\end{array}$ \\
\hline Bellevue, 2 wells .... & 212 & $1 \frac{1}{2}$ & Flows 15 to 20 & +4 to +6 & Basal Chesapeake.. & \\
\hline Bothwell ........... & 300 & 6 & 20 & -7 & Newark. & \\
\hline Bowlers Wharf ...... & 143 & 4 & 7 & Flows. & Chesapeake.. & Soft water. \\
\hline Carters Creek........ & 330 & $\cdots$ & $\ldots \ldots \ldots \ldots$ & +12 & .....do............... & \\
\hline Clay Bank.......... & 538 & $1 \frac{1}{2}$ & Flows 2 & +4 & Basal Pamunkey?.. & \\
\hline Clifton, 2 wells ..... & 175 & $1 \frac{1}{2}$ & $\begin{array}{l}\text { Flows } 10 \text { to } \\
12 .\end{array}$ & +4 to +6 & .... do.............. & \\
\hline Coan, 8 wells ... & 270 & $1 \frac{1}{2}$ & Flows $2 \frac{1}{4}$ & +12 & Basal Chesapeake.. & $\begin{array}{l}\text { Water also at } 240 \\
\text { feet. }\end{array}$ \\
\hline Coan, 1 well. & 315 & 4 & 15 & +12 & ....do.. & \\
\hline Coles Point.......... & 220 & $1 \frac{1}{2}$ & 3 & +12 & .... do....... & \\
\hline $\begin{array}{l}\text { Colonial Beach, } 5 \\
\text { wells. }\end{array}$ & 250 & $1 \frac{1}{2}$ & 5 & +8 to +15 & Basal Pamunkey .. & $\begin{array}{l}\text { Water also at } 160 \\
\text { feet. }\end{array}$ \\
\hline Courtland, 30 wells.. & 160 & $\cdots$ & 30 & ...... & Chesapeake?.. & \\
\hline Cowart .............. & 288 & 2 & Flows 2 & +6 & Basal Chesapeake.. & \\
\hline Ditchley............. & 620 & $1 \frac{1}{2}$ & Flows 2 & +4 to +6 & ........ & \\
\hline Dendron............ & 386 & 6 & None. & $\ldots \ldots \ldots$ & $\ldots \ldots \ldots \ldots \ldots$ & \\
\hline $\begin{array}{l}\text { Dudleys Ferry, } 4 \\
\text { wells. }\end{array}$ & 175 & $1 \frac{1}{2}$ & Flows 10 & 4 to 6 & Basal Chesapeake.. & \\
\hline Dymer Creek ........ & 507 & 3 & Flows 7 & & Basal Pamunkey,.. & $\begin{array}{l}\text { Water also at } 240 \\
\text { and } 464 \text { feet. }\end{array}$ \\
\hline Fairport... & $393 \frac{1}{2}$ & $1 \frac{1}{8}$ & Flows 2 & & Basal Chesapeake.. & Soft, good water. \\
\hline Fort Monroe......... & 907 & $\cdots$ & None. & $\cdots .$. & Potomae? .......... & \\
\hline $\begin{array}{l}\text { Fort Mon roe, Cham- } \\
\text { berlin Hotel. }\end{array}$ & 945 & & Flows 50 & +10 & .....do............. & $\begin{array}{l}\text { slightly saline wa- } \\
\text { ter. }\end{array}$ \\
\hline Franklin, 16 wells... & 130 & .. & Many. & Flow. & Chesapeake..... & \\
\hline Gabels Mill ........ . & 226 & $1 \frac{1}{2}$ & Flows 20 & +10 & Basal Chesapeake.. & \\
\hline $\begin{array}{l}\text { Gloucester Court } \\
\text { House. }\end{array}$ & 600 & ] & None. & $\cdots$. & Pamunkey?....... & $\begin{array}{l}\text { Stopped at rock } \\
\text { stratum. }\end{array}$ \\
\hline Homewood, 5 wells. & 317 & $1 \frac{1}{2}$ & Flows 30 & & Basal Chesapeake.. & $\begin{array}{l}\text { Fine water } 54^{\circ} \text {. } \\
\text { Sulphurous wa- } \\
\text { ter at } 270 \text { feet. }\end{array}$ \\
\hline & 112 & 1 & Fair supply. & +2 & Chesapeake... & $\begin{array}{l}\text { Ferruginous wa- } \\
\text { ter. }\end{array}$ \\
\hline Jamestown .......... & 248 & 3 & Flows $2 \frac{1}{2}$ & +35 & Basal Chesapeake.. & Fine water $68^{\circ}$. \\
\hline King and Queen..... & 200 & 2 & Flows 1 & $\ldots$. & Basal Pamunkey?.. & \\
\hline Kinsale............ & 235 & $1 \frac{1}{2}$ & 5 & +15 & Basal Chesapeake.. & \\
\hline Lancaster .... & 250 & $\cdots$ & Flows 12 & $\ldots$. & .... do.............. & \\
\hline Do.............. & $285 ?$ & $\cdots$ & n........... & …......... & $\cdots \cdot$ & \\
\hline Lester Manor, 3 wolls. & 200 & $1 \frac{1}{2}$ & Flows 12 & +8 to +12 & Basal Pamunkey?.. & \\
\hline Lewisetta........... & $317 \frac{1}{9}$ & $\cdots$ & …....... & $\cdots \cdot$ & Basal Chesapeake.. & \\
\hline Little Plymouth ..... & 168 & 2 & Flows 2 & $\ldots$ & .....do.......... & \\
\hline Monaskon ........... & 255 & & (n......... & $\cdots$ & ....do.......... & \\
\hline Monatico Creek...... & 250 & $1 \frac{1}{2}$ & Flows 2 & + & .....do............... & \\
\hline$\underset{\text { Chureh. }}{\text { Mount }}$ Carmel & 190 & & Flows $1 \frac{1}{2}$ & +6 & Chesapeake... & \\
\hline Naylors...... & 386 & $1 \frac{1}{2}$ & Flows 3 & +45 & Basal Pamunkey... & $\begin{array}{l}\text { Much water at } 326 \\
\text { feet. }\end{array}$ \\
\hline
\end{tabular}

$a+$, feet above the surface; - , feet below the surface. 
Partial list of deep wells-Continued.

\begin{tabular}{|c|c|c|c|c|c|c|}
\hline Location. & Depth. & Size. & $\begin{array}{l}\text { Capacity per } \\
\text { minute. }\end{array}$ & \begin{tabular}{|l} 
Height \\
to which \\
water \\
rises.
\end{tabular} & Horizon. & Remarks. \\
\hline & Feet. & In. & Gallons. & Feet. & & \multirow{5}{*}{$\begin{array}{l}\text { Very hard water. } \\
\text { Saline water. }\end{array}$} \\
\hline Newcastle.. & 187 & $1 \frac{1}{2}$ & Flows 10 & +2 & - ............. & \\
\hline Newport News. & \pm 600 & & None. & $\ldots$. & Chesapeake. & \\
\hline Norfolk............. & 147 & $6 ?$ & Much. & -6 & .....do.......... & \\
\hline $\begin{array}{l}\text { Norfolk, Lambert } \\
\text { Point. }\end{array}$ & 610 & .. & 65 & $\therefore .$. & ..... do..... & \\
\hline $\begin{array}{l}\text { Norfolk, Money } \\
\text { Point. }\end{array}$ & 562 & & Much. & +5 & ....do. & $\begin{array}{l}\text { Ferruginous wa- } \\
\text { ter. }\end{array}$ \\
\hline North End Point .... & 1,172 & $\cdots$ & None. & . & Potomac.... & \multirow{4}{*}{$\begin{array}{l}140-486 \text { feet; no } \\
\text { water. }\end{array}$} \\
\hline Oak Springs... & 400 & $1 \frac{1}{2}$ & Flows 10-12 & +6 & $\ldots$ & \\
\hline Onancock ............ & 140 & $4 \frac{1}{2}$ & 5 & & Chesapeake........ & \\
\hline Plum Point, 3 wells.. & 168 & $1 \frac{1}{2}$ & Flows 10-12 & $+8-12$ & Basal Chesapeake.. & \\
\hline Possums Nose........ & 200 & $\cdots$ & n.............. & $\cdots$ & Potomac ........... & \multirow[b]{2}{*}{ Unfinished. } \\
\hline Providence Forge.... & 80 & $1 \frac{1}{2}$ & None. & 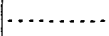 & Chesapeake... & \\
\hline Puritan Bay, 2 wells. & 215 & $1 \frac{1}{2}$ & Flows $10-12$ & $+4-6$ & Basal Chesapeake.. & \multirow{7}{*}{$\begin{array}{l}\text { Surface contami- } \\
\text { nation. }\end{array}$} \\
\hline Puritan Bay, 1 well. . & 180 & $1 \frac{1}{2}$ & Flows $10-12$ & $+4-6$ & ............ & \\
\hline Quantico ........... & 350 & $\cdots$ & $4-5$ & Flows. & Basal Potomac..... & \\
\hline Ragged Point........ & 225 & $1 \frac{1}{2}$ & 1 & 12 & Basal Chesapeake.. & \\
\hline Richmond: & & & & & & \\
\hline Paper mill... & 400 & & Fair. & & Granite.. & \\
\hline Sherwood Park.. & 900 & & None. & & .....do. & \\
\hline $\begin{array}{r}\text { Sherwood Park, } 1 \\
\text { mile northeast. }\end{array}$ & 250 & & None. & & .....do.... & \multirow[b]{2}{*}{ Fine water. } \\
\hline Ginter's farm.... & 400 & & Satisfactory. & & ......do... & \\
\hline Sandy Point: & & & & & & \multirow[b]{3}{*}{$\begin{array}{l}\text { Nowater below } 270 \\
\text { feet; rock, } 270- \\
560 \text { feet. }\end{array}$} \\
\hline $\begin{array}{l}\text { Westmoreland } \\
\text { County. }\end{array}$ & 235 & $1 \frac{1}{2}$ & 3 & +12 & Basal Ches & \\
\hline Fairfax County.. & 560 & & Satisfactory. & -24 & Basal Potor & \\
\hline Sharps Wharf. & 235 & $1 \frac{1}{2}$ & Flows 12-35 & +24 & Basal Chesapeake.. & \multirow{2}{*}{$\begin{array}{l}\text { Water also at } 240 \\
\text { feet. }\end{array}$} \\
\hline Do......... & 360 & & & 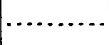 & Pamunkey .......... & \\
\hline $\begin{array}{l}\text { Sheppard's ware- } \\
\text { house, } 2 \text { wells. }\end{array}$ & 160 & $1 \frac{1}{2}$ & Flows 10-15 & $+6-8$ & Basal Chesapeake.. & \multirow{4}{*}{$\begin{array}{l}\text { Ferruginous wa- } \\
\text { ter. }\end{array}$} \\
\hline Swan Point......... & +100 & & & & Chesapeal & \\
\hline Virginia Beach ...... & 70 & & Fair supply. & ( & Upper Chesapeake. & \\
\hline Walkerton, 2 wells.. & 315 & $1 \frac{2}{2}$ & Flows $5-8$ & $+4-6$ & Potom & \\
\hline Weems ............ & - 260 & & ............ & n......... & Chesapeake........ & \multirow{8}{*}{$\begin{array}{l}\text { Under hard rock } \\
\text { stratum. } \\
\text { To top of rock } \\
\text { stratum. }\end{array}$} \\
\hline West Point, 200 wells. & 160 & $1 \frac{1}{2}$ & Average 12 & $\begin{array}{l}\text { Average } \\
+2\end{array}$ & Basal Chesapeake.. & \\
\hline Whealtons & 250 & & 20 & 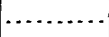 & Basal Chesapeake? & \\
\hline White House, 3 wells. & $180-230$ & $1 \frac{1}{2}$ & $1-6$ & $+5-20$ & Basal Chesapeake.. & \\
\hline Williamsburg . & 876 & & None. & & Potomac ........... & \\
\hline Do.............. & 280 & & Many. & . & Basal Chesapake.. & \\
\hline Windmill Point ... & 430 & & None. & & $\begin{array}{l}\text { Near to basal } \\
\text { Chesapeake. }\end{array}$ & \\
\hline Zuni. & 161 & & Flows 2 & & Chesapeake......... & \\
\hline
\end{tabular}


PIEDMONT PLATEAU.

The Piedmont Plateau extends from the Coastal Plain on the east to the foot of the Appalachian Mountains on the west. Its surface is made up mainly of more or less crystalline igneous or metamorphic rocks, but is marked by a number of basins of Triassic. shales and sandstones.

Over the greater part of the Piedmont Plateau the uplands are smooth and rounded and the streams flow near their heads in broad, shallow valleys. In their lower courses the streams, especially the larger ones, have formed deep channels, and a strongly rolling topography has been developed. Toward the west the topography merges into that of the Appalachian Mountain belt.

Crystalline rocks. - The crystalline rocks of the Piedmont belt are deeply weathered at the surface and are broken by numerous joints that extend to considerable depths. As in similar regions elsewhere, the weathered upper portion everywhere furnishes supplies for shallow wells. Few deep wells have been drilled, but it is probable that moderate amounts of water would be obtained in a considerable percentage of the wells sunk. The water, however, would be likely in many instances to be rather strongly mineralized and unsuitable for some purposes. Moreover, because of the uncertainty of the presence of joints or other water-bearing fissures in the rock, the occurrence or nonoccurrence of water in a well at a given locality can seldom be predicted.

Triassic rocks.-The Triassic rocks consist of a series of shales and sandstones, with a few coals, etc., occupying basin-like depressions in the Piedmont Plateau. Moderate or small supplies of water are generally obtained by the shallower wells. Deeper wells would probably obtain considerable amounts in many instances, although, as in other Triassic areas, the waters are likely to be mineralized. Strong springs occur along certain of the faults which cut this area, and it is not improbable that flowing waters could be obtained in some localities.

\section{APPALACHIAN MOUNTAIN BELT.}

The term Appalachian Mountain belt is used in a broad way to include the entire belt of folded rocks lying between the Piedmont Plateau and the Cumberland and Allegheny plateaus of West Virginia and Pennsylvania. The rocks are of Cambrian, Silurian, and Devonian age, and include quartzites, sandstones, shales, and limestones. Near the eastern limits of the belt, separated from the Piedmont Plateau by only a narrow strip of folded rocks, is the Shenandoah Valley. This valley is underlain by Cambro-Silurian limestones.

The Appalachian Mountain belt is in general thinly inhabited and contains few wells. Springs abound and constitute the main source 
of supply of the inhabitants. The quartzites carry very little water in their denser portions, although springs̀ of considerable size sometimes issue from their more porous parts. The springs of the shales are numerous, but are generally small. In the limestone area of the Shenandoah Valley, a region which is relatively thickly inhabited, dependence is placed largely on cisterns, the waters of the limestone being of uncertain occurrence. Near the borders of the limestone area, however, springs occur at some places, and it is probable that deep wells would often procure good supplies at these localities, but as the water sometimes occurs in definite underground channels successful wells would not always be obtained at such places.

The waters of many of the springs of the higher portions of the Appalachian belt are warm, and at a number of places the springs have been developed as resorts. At other springs the waters are bottled and sold for medicinal purposes. The association of these springs with anticlines was long ago pointed out by W. B. Rogers. It is not improbable that here, as in other regions, in some instances the locations of the springs were determined by faults.

\section{CUMBERLAND PLATEAU.}

The name Cumberland Plateau is applied to the elevated area of Carboniferous rocks lying northwest of the Appalachian Mountain belt. Only a small part of this area is included in Virginia, and that lies in the extreme western part of the State. The underground water supplies of this region are like those of the portion of the plateau included in Pennsylvania and Maryland. Practically no deep wells have been sunk, but it is probable that such wells if put down would obtain water from some one of the more sandy beds. It might even rise to the surface in synclines or other favorable situations. Springs are fairly numerous, but small.

\section{COMMERCIAL SPRINGS.}

During the year 1902 sales of water were reported from 48 springs, including representatives from each of the geologic divisions except the Cumberland Plateau. These are as follows: ${ }^{a}$

* Atna Lithia Springs, Roanoke, Roanoke County.

* Augusta White Lithia Spring, near Augusta Springs.

* Basic Lithia Spring, Basic City, Augusta County.

* Bear Lithia Springs, near Elkton, Rockingham County.

$\dagger$ Beaufont Lithia Spring, Beaufont, Chesterfield County.

$\dagger$ Bellfont Spring, near Manchester, Chesterfield County.

$\dagger$ Berry Hill Mineral Spring, near Elkwood, Culpeper County.

* Blue Ridge Springs, Botetourt County.

$†$ Buffalo Lithia Springs, Buffalo Lithia Springs, Mecklenburg County.

$a$ Peale, A. C., Mineral Resources U. S. for 1902, U. S. Geol, Survey, 1904, p. 996. 
† Chase City Mineral Springs, Chase City, Mecklenburg County.

$\dagger$ Como Lithia Spring, East Richmond, Henrico County.

† Coppahaunk Lithia Arsenic Springs, near Waverly, Sussex County.

* Cove Lithia Spring, Wytheville, Wythe County.

* Craig Healing Spring, Vista Craig, Craig County.

* Crockett Arsenic Lithia Spring, Shawsville, Montgomery County.

Diamond Spring, Norfolk County.

$\dagger$ Erup Mineral Spring, near Glen Carlyn, Alexandria County.

† Farmville Lithia Springs, Cumberland County, near Farmville, Prince Edward County.

$\dagger$ Fonticello Lithia Spring, Chesterfield County, near Richmond.

* Golindo Lithia Springs, Weyers Cave, Augusta County.

$\dagger$ Harris Anti-Dyspeptic and Tonic Spring, Burkeville, Nottoway County.

* Healing Springs, Healing Springs, Bath County.

$\dagger$ Houston Lithia Spring, Houston, Halifax County.

$\dagger$ Hume Springs, St. Elmo, Alexandria County.

* Hunter's Pulaski Alum Springs, Walkers Creek, Pulaski County.

$\dagger$ Jeffress Lithia Silica Springs, Jeffress, Mecklenburg County.

* Jordan White Sulphur Spring, Stephenson, Frederick County.

$\dagger$ Lone Jack Spring, Candless Mountain, Campbell County.

† Magee's Chlorinated Lithia Springs, Clarksville, Mecklenburg County.

$\dagger$ Massanetta Springs, Harrisonburg, Rockingham County.

* Montvale Hygeia Spring, Montvale, Bedford County.

* Nye Lithia Springs, Wytheville, Wythe County.

* O'Connell Lithia Spring, near Stribling Springs, Augusta County.

†Otterburn Lithia and Magnesia Springs, Amelia, Amelia County.

$\dagger$ Paeonian Spring, Paeonian Springs, Loudoun County.

† Pontiac (formerly Powhatan) Spring, near Falls Church, Alexandria County.

$\dagger$ Powhatan Lithia and Alum Springs, near Tobaccoville, Powhatan County.

* Rockbridge Alum Springs, Alum Springs, Rockbridge County.

* Rubino Healing Lithia Springs, Healing, Bath County.

* Seawright Magnesian Lithia Spring, near Staunton, Augusta County.

* Seven Springs, near Glade Spring, Washington County.

* Shenandoah Alum Springs, near North Mountain, Shenandoah̀ County.

† Sublett's Lithia Spring, near Danville, Pittsylvania County.

† Swineford's Arsenic Lithia Springs, Osceola, Chesterfield County.

* Virginia Magnesian Alkaline Springs, near Staunton, Augusta County.

* Virginia Waukesha Lithia Springs, Staunton, Augusta County.

* Wallaw hatoola Alum Springs, near Millboro Spring, Bath County.

† Wolf Trap Lithią Springs, Wolf Trap Depot, Halifax County.

Of these only the Diamond Springs of Norfolk County appear to be in the Coastal Plain. Of the remainder those marked * are in the Mountain belt, while those marked + are in the piedmont belt. The total output for 1902 was $2,442,398$ gallons, having a value of $\$ 423,212$.

\section{PRINCIPAL PUBLICATIONS.}

Mineral springs of the United States, by A. C. Peale: Bull. U. S. Geol. Survey No. 32 , pp. 54-68.

Artesian-well prospects of the Atlantic Coastal Plain region, by N. H. Darton: Bull. U. S. Geol. Survey No. 138, pp. 162-190. 
Preliminary list of deep borings in the United States, pt. 2, by N. H. Darton: WaterSupply and Irrig. Paper U. S. Geol. Survey No. 61, p. 60.

Description of the Fredericksburg quadrangle, Maryland and Virginia, by N. H. Darton: Geol. Atlas U. S., folio 13, U. S. Geol. Survey.

Description of the Nomini quadrangle, Maryland and Virginia, by N. H. Darton: Geol. Atlas U. S., folio 23, U. S. Geol. Survey.

Description of the Washington quadrangle, Maryland, District of Columbia, and Virginia, by N. H. Darton and A. Keith: Geol. Atlas U. S., folio 70, U. S. Geol. Survey.

Description of the Norfolk quadrangle, Virginia and North Carolina, by N, H. Darton: Geol. Atlas U. S., folio 80, U. S. Geol. Survey. 


\section{NORTH CAROLINA.}

By M. L. Fuller.

In North Carolina only two of the geographic and topographic belts recognized in Virginia are extensively developed. These are the Coastal Plain and the Piedmont Plateau. That part of the Appalachian Mountain belt which consists of folded sedimentary rocks is present only in the extreme western portion of the State. The Piedmont Plateau, however, becomes in this State mountainous as it approaches the former belt and topographically grades more or less imperceptibly into it. The Cumberland Plateau is not represented in the State.

\section{COASTAI PIAAIN. $a$}

The geology of the Coastal Plain in North Carolina differs from that of Virginia principally in the reappearance of the marine Cretaceous beds, which thicken rapidly and rise to tide-water level and above nearly as far east as Wilmington. The Eocene formation thins somewhat, and in the southern counties lies almost entirely above tide level, on an irregular floor of marine Cretaceous sands and marls.

The Chesapeake beds thin rapidly southward, and lie mostly above tide level in shallow basins on the Eocene or marine Cretaceous.

The Potomac, the most important water-bearing formation of the Coastal Plain region, is best developed along the western border of this region in the counties southwest of the Neuse River-Harnett, Moore, and Richmond. In these counties the Potomac strata are exposed at intervals over a considerable area; and, dipping gently southeastward on the eroded surface of the crystalline rocks, doubtless carry considerable quantities of water. The Potomac formation also reaches the surface over limited areas, both north and south of Roanoke River above Weldon, and there are also outcrops of the formation at intervals between the Roanoke and Neuse rivers, but in this region the exposed areas of the formation are far less extensive than between the

a Compiled from notes of J. A. Holmes published in Bull. U. S. Geol, Survey No. 138, 1896, pp. 190-19 :. 
Neuse and the Pedee, and consequently the underground water supplies below the Tertiary marls of the counties between the Neuse and Roanoke will probably prove to be less abundant than in the more southerly counties.

The general geologic structure of the Coastal Plain in North Carolina is indicated in the accompanying section by Professor Holmes, fig. 20.

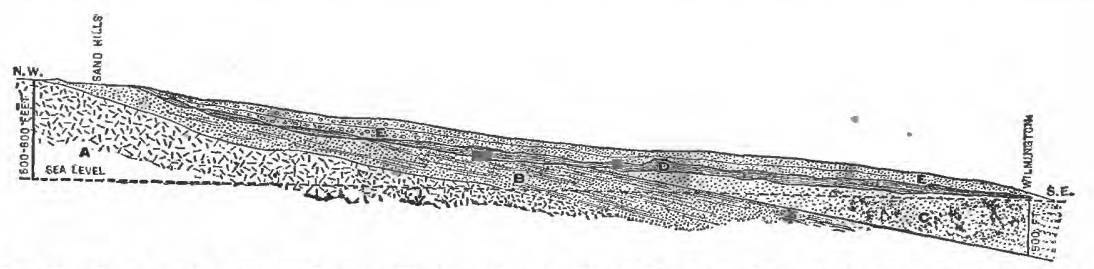

Fig. 20.-Cross section of tine Coastal Plain region in North Carolina, from near Sanford to the coast near Wilmington. A, crystalline sehists; B, Potomac sand, arkose, and clays; C, marine Cretaceous sands, marls, etc.; D, Tertiary marls and shell rock (Eocene and Chesapeake); E, Lafayette and overlying Columbia formation. Vertical scale greatly exaggerated.

It is not yet possible to present a review of the water horizons or of the well prospects in the State, but the following partial list of wells shows the results obtained by drilling at a considerable number of points.

Partial list of deep wells in the Coastal Plain region of North Carolina.

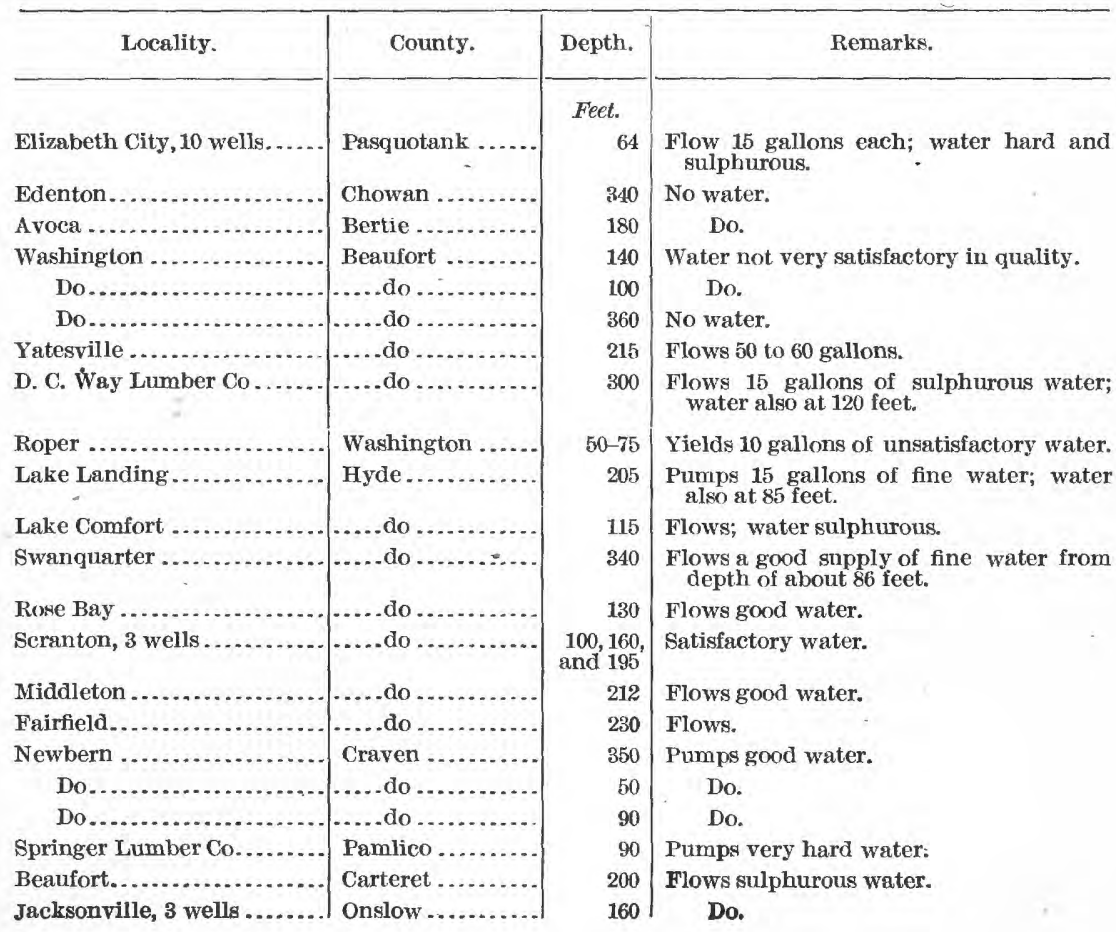


Partial list of deep wells in the Constal Plnin region of North Carolina-Continued.

\begin{tabular}{|c|c|c|c|}
\hline Locality. : & County. & Depth. & Remarks. \\
\hline & & Feet. & \\
\hline Tarboro . & Edgecombe........ & 75 & Flows 2 gallons. \\
\hline Do... & .....do... & 82 & Pumps. \\
\hline Do....... & ..... do .... & 160 & Do. \\
\hline Do..... & ..... do ... & 218 & Flows. \\
\hline Greenville............. & Pitt........ & $200+$ & Water obtained, but pipe filled with sand. \\
\hline Wilson Cotton Mills .. & Wilson .. & 125 & Hard water. \\
\hline Goldsboro ................... & Wayne ..... & 266 & Quantity and quality satisfactory. \\
\hline Kinston .................. & Lenoir... & 115 & Pipe filled with quicksand. \\
\hline Lagrange (5 miles south) .... & ..... do .... & 57 & Flowing well. \\
\hline Warsaw ....... & Duplin . & ..... & In progess. \\
\hline Burgaw ............. & Pender.... & 100 & $\begin{array}{l}\text { Water to near surface; quantity and } \\
\text { quality satisfactory. }\end{array}$ \\
\hline Longcreek. . & ..... do .... & 175 & Stopped in quicksand. \\
\hline Vineland ..... & Columbus .. & 63 & Flows 4 gallons. \\
\hline Do.......... & .... do ............. & 225 & Water nearly to surface. \\
\hline Wilmington ........... & New Hanover.... & 495 & Flows 75 gallons; very saline water. \\
\hline Wilmington, 3 wells.. & ..... do ...... & $84-100$ & Pump 400 gallons each of good water. \\
\hline Hammocks............ & ..... do ..... & 400 & $\begin{array}{l}\text { 8-gallon fiow of good water from } 100 \\
\text { feet (?). }\end{array}$ \\
\hline
\end{tabular}

\section{PIEDMONT PLATEAU.}

The Piedmont Plateau lies between the Coastal Plain and the folded mountain belt, as in Virginia. The rocks are crystalline (igneous or metamorphic), and are characterized by basins of Triassic shales and sandstones similar to those in Virginia.

The topography is much the same as in Virginia, except that it is more rugged in the western portion next to the mountains. The crystalline rocks are even more weathered than in Virginia and are similarly broken by joints. Water in small to moderate amounts could probably be obtained almost anywhere within this belt, although large supplies are not to be looked for. It would rarely, if ever, rise to the surface, and is likely to be mineralized. The waters of the springs of the belt contain large amounts of mineral matter and are extensively used for medicinal and table purposes.

The Triassic rocks are somewhat similar to those in Virginia, and doubtless carry considerable water in their more porous beds. Very few deep wells, however, have been sunk in the Trias ic areas.

\section{APPALACHIAN MOUNTAIN BELT.}

As has been indicated, only a part of the Appalachian Mountain belt lies within the State of North Carolina. The rocks represented are more metamorphic than those in the States previously described, and are frequently crystalline or semicrystalline. A few of the less metamorphic rocks also occur. The mountain belt in this State is relatively 
inaccessible and very thinly inhabited. The numerous springs which occur throughout the belt form practically the entire source of water supply of the inhabitants.

\section{MINERAL SPRINGS.}

The important mineral springs of North Carolina are located on the Piedmont Plateau. Of the 10 springs that report sales of water in 1902 only 1-the Seven Springs of Wayne County - is in the Coastal Plain. The following is a list of these springs: ${ }^{a}$
Alkalithia Spring, Alkalithia Springs, Alexander County.
Barium Rock Spring, Barium Springs, Iredell County.
Jackson Springs, Jackson Springs, Moore County.
Lemon Springs, Lemon Springs Station, Moore County.
Mida Spring, near Charlotte, Mecklenburg County.
Panacea Springs, near littleton, Warren County.
Park's Spring, Caswell County, near Danville, Va.
Seven Springs, Sevensprings, Wayne County.
Thompson Bromine Arsenic Springs, Crumpler, Ashe County.
Vade Mecum Spring, Vade Mecum, Stokes County.

The total quantity of water sold in 1902 is given as 104,400 gallons, having a value of $\$ 18,795$.

\section{PRINCIPAI PUBLICATIONS.}

Mineral springs of the United States, by A. C. Peale: Bull. U. S. Geol. Survey No. 32 , pp. 74-78.

Artesian-well prospects of the Atlantic Coastal Plain region, by N. H. Darton [North Carolina, by J. A. Holmes]: Bull. U. S. Geol. Survey. No. 138, pp. 190-207.

Preliminary list of deep borings in the United States, Pt. 2, by N. H. Darton: Water-Supply and Irrig. Paper U. S. Geol. Survey No. 61, pp. 20.

Water resources of the Cowee and Pisgah quadrangles, North Carolina, by H. S. Gale: Water-Supply and Irrig. Paper U. S. Geol. Survey No. 110, pp. 174-176.

$a$ Peale, A. C., Mineral Resources U. S. for 1902, U. S. Geol. Survey, 1904, p. 996.

IRR $114-05-10$ 


\title{
SOUTH CAROLINA.
}

\author{
By L. C. GLenn.
}

\section{SUBDIVISIONS.}

South Carolina is divided by a line running northeastward from Augusta, Ga., through Columbia, Camden, and Cheraw, S. C., into a Coastal Plain portion to the southeast and a Piedmont Plateau portion to the northwest. The Coastal Plain region is somewhat the larger of the two divisions and consists geologically of interstratified beds of sand, clay, and marl of Cretaceous or later age that are as yet mostly unconsolidated. The Piedmont Platean region consists geologically of crystalline rocks whose exact age is unknown, although they are thought to be largely Archean or Algonkian. Because of this difference in their geology the water supplies and water-supply problems of the two sections of the State differ widely in their nature. Each section will be considered separately.

The climatic factors affecting the water supplies are simple and may be briefly stated. The annual rainfall varies somewhat from year to year, but averages about 50 inches and is almost uniformly distributed over the State. Autumn is the dryest of the seasons, receiving 2 or 3 inches less than its normal proportion of the rainfall, and in consequence streams are usually lowest in the late fall. Winter receives 2 or 3 inches more than its proportion. The streams of the Coastal Plain are never frozen over. During severe winters ice may occasionally form on streams in the inner part of the Piedmont region, but it lasts only a few days at a time and never becomes thick enough to interfere with the utilization of the streams for water power.

\section{GEOLOGY AND WATER SUPPLY.}

\section{PIEDMONT PLATEAU.}

GENERAL FEATURES.

Character.-Viewed broadly the Piedmont Plateau is essentially a plane surface with an average elevation along its outer or southeastern edge of 500 feet. It rises gently to the northwest to an average elevation of 1,000 feet along its inner edge. Beneath this general surface the main streams which flow southeastward have incised their courses 50 to 150 feet, and with their many tributaries have sculptured 
it into a gently rolling plateau that breaks into hills near the main drainage ways.

Rocks. - The rocks of the Piedmont Plateau consist of highly metamorphosed gneisses and schists, cut by granites and later intersected by many dikes, chiefly of diabase and presumably of Newark age. The gneisses and schists are regarded as pre-Cambrian in age. They have suffered such profound and repeated metamorphism that in very many cases their original character has been lost. Original bedding planes, if any ever existed, have been obliterated and planes of schistosity have been developed that have prevailingly a northeast-southwest strike and steep dips that range between southeast and northwest. In a few places narrow broken belts of crystalline limestone or of metamorphosed conglomerates indicate original sedimentary beds.

The granites are prevailingly coarsely crystalline to porphyritic, though some areas are of fine and uniform grain. They were intruded at various periods, all of which were probably pre-Cambrian, and have since been exposed at the surface by long and profound erosion, for it seems highly probable that the Piedmont Plateau has been a land surface since early Paleozoic time.

Residual soil mantle.-During all this time the disintegration and weathering of the crystalline rocks of the plateau has been in progress. During most of the time the solid rocks have been covered with a blanket of weathered material, which has at certain periods of uplift been largely removed to furnish material to build the Coastal Plain. At present a blanket of disintegrated material 50 to 150 feet thick overlies the solid rock over practically all of the Piedmont region. Much of this disintegrated material, especially near the surface, is a very fine-grained red clay, that makes the Piedmont streams a muddy red or yellow color.

WATER SUPPlies OF PIEDMONT PLATEAU.

Effect of residual mantle. - The residual mantle plays an important rôle in relation to the water supply of the Piedmont region, for much of the rainfall is absorbed by it and held to be fed out gradually to springs and streams, thus making the stream flow more uniform than if the undisintegrated crystallines reached nearly to the surface. The main streams of the region have cut down through this blanket of disintegrated material to the solid rock beneath, which often shows in exposed ledges along their courses. Many of their tributaries have cut narrow valleys far back into the interstream area.

Springs.-Along the sides of the valleys, large and small, are found many unfailing springs, whose waters are usually free from mineral impurities of any kind. In the early settlement of the Piedmont region of South Carolina these springs were universally used for household water supplies. Wells and cisterns were unknown. The 
pioneer built his house near some bold spring, very often selecting a site on the hill slope or down in the small valley itself. Springs thus determined the location of the homes of the first settlers and for years continued to furnish practically the only water supply. They are used in very many cases to-day, and, in spite of the clearing of the land and the comparatively thick settlement of the country, have not failed or become polluted by man's presence, but they are still safe and satisfactory sources of domestic water supply.

There are a number of well-known mineral springs in the Piedmont region, at some of which hotels with good accommodations have long enjoyed wide popularity as summer resorts. The waters of these springs generally contain sulphates and carbonates of calcium, magnesium, sodium, and potassium. Some contain lithia and some are chalybeate.

The following springs, ${ }^{a}$ all located within the Piedmont Plateau, reported shipments in 1902:

Buffalo Lick Springs, near Carlisle, Union County.

Chick Springs, near Taylor Station, Greenville County.

Cokesbury Mineral Spring, Cokesbury, Greenwood County.

Garrett Mineral Spring, Spartanburg, Spartanburg County.

Glowing Spring, near Calhoun Falls, Abbeville County.

Harris Lithia Spring, Harris Springs, Laurens County.

Rives Mineral Spring, Lancaster, Lancaster County.

West Springs, West Springs, Union County.

White Stone Lithia Spring, Spartanburg, Spartanburg County.

The aggregate amount of water sold is stated as 259,706 gallons, with a value of $\$ 76,525$.

Open wells.-With increasing wealth and culture there came a demand for better building sites, and houses began to be erected back on the nearly level interstream uplands remote from springs, and the digging of open wells was begun. These open wells furnish the greater part of the water supply of the Piedmont region to-day. In some cases pure soft water is obtained before solid rock has been reached; in others water is obtained just on top of the solid rock, while in still others it is occasionally necessary to go into the solid rock some distance to a water-bearing seam. The wells of the Piedmont region range from 40 to 70 feet in depth, and they usually have from 5 to 10 feet of water, and rarely fail during dry seasons. The disintegrated material through which they are dug is not firm enough to be left unwalled, so that a curbing, usually of loose stone, is put in. In many cases not enough attention is paid to sanitary precautions, but as the water entering the well under the usual circumstances filters down through a considerable thickness of sand and clay, it is largely though not entirely protected from contamination. Occasionally one finds a 
bored well of 8 or 10 inches in diameter, though the dug well is far more common. These bored wells differ from the dug ones chiefly by being cheaper to sink, but they are more difficult to clean out.

Deep wells. - Aside from the streams of the region the only possible source for considerable water supplies is the subsurface waters. The presence of granites and crumpled gneisses and schists in the region precludes the hope of securing deep artesian waters, for the structure of such rocks is unfavorable to artesian conditions.

Some Piedmont towns, however, moved by the idea that they could get artesian waters if they only bored deep enough have drilled wells several hundred feet into the crystalline rock, and, except in very few cases, have been rewarded with supplies of water that have risen to a height coinciding with the level of the ground-water surface in the rocks around the well, but such supplies are not artesian. The rocks of the region are traversed by seams and fissures, which everywhere below the ground-water level are filled with water. The deeply drilled hole has cut across enough such fissures to obtain a large supply of water for the pumps, yet this water is derived, not from a great depth nor from a long distance, but from the great body of ground water near the surface and immediately around the well. If the fissures in the solid rock are very numerous, the area supplying the water is an inverted cone whose apex is the lowest point of entry in the bore hole and whose base is a large circular area of the ground-water surface around the well mouth, and only one, two, or three score feet beneath the surface of the town, with its innumerable sources of pollution of every kind. . If the well is supplied by only one fissure or by a very few fissures, they must be correspondingly larger and furnish more direct and easy lines of flow to the well. They may extend almost uninterrupted nearly up to the surface and furnish a direct channel for surface waters to enter the well.

The amount of water that can be pumped from such wells is usually large and analyses made when the well is first completed have shown a good, pure, clear, and usually soft water, well adapted to almost any purpose. But while at first such deep wells may be protected from contamination by the surface-soil layer, which acts as a filter, and the water may be pure and wholesome, yet they are very apt sooner or later to become contaminated. Constant pumping from them soon causes the indrafts supplying the water to open better channels through the fissures and allows more direct ingress of waters from the surface. These channels sooner or later are able to carry surface contamination directly into the well. Such deep wells are therefore at best open to grave suspicion and constantly need careful watching. This need is all the more necessary because of the fancied security given by the very favorable analysis of the water when first used. Such careful watching will usually result in the condemnation and 
closing of the well in a few years, especially if the town be of considerable size, so that there is furnished to the soil a large amount of contaminating organic material. A well of this kind drilled over 2,000 feet deep in Atlanta, Ga., some years ago, which at first furnished a large amount of acceptable water, was ordered closed by the board of health after a few years' use because of sewage pollution.

At Chester the first deep well sunk into the crystalline rocks failed to strike a single fissure, but was drilled perfectly dry 500 or 600 feet into a solid mass of porphy ritic diorite. It was abandoned and a second attempt was made in another part of the town that was successful in striking a water-bearing fissure at 404 feet. A failure may at any time result from deep drilling in the crystallines, though as a general rule fissures are abundant enough to make it reasonably certain that water will be obtained in such wells at a reasonable depth.

Another source of water supply adequate for manufacturing plants or large institutions where only a few hundred thousand gallons are used daily, but usually not deemed sufficient for city supplies, is coming into use in the Piedmont region. It consists of tube wells, which are sunk usually in groups through the decomposed surface material down to solid rock, and which derive their supplies from water circulating slowly just on top of this rock. These wells are usually only a few inches in diameter and vary in depth with the depth of the surface disintegration, ranging from 30 to 80 feet in most cases. They are sunk along or near the lowest line of a natural valley or depressed area toward which a considerable surface area slopes, the larger the basin's extent, other things being equal, the larger the probable supply. Much of the rain falling in the basin percolates down through the soil and moves slowly along on the bed-rock surface, the slope of which usually coincides in the main with that of the soil surface above it. In some cases the clay soil near the surface may be so close grained as to act as an impervious covering for the water in the partly disintegrated and loosened rock beneath, so that wells sunk in this manner may be truly artesian - that is, they may have a natural flow caused by the pressure of the water confined beneath an impervious layer. The distance in this case from which the water comes is of course limited to the basin in which the well is sunk. It is a local artesian basin formed under exceptional conditions.

Such supplies of water have been found uniformly satisfactory. This result has of course been attained by selecting basins free from sources of contamination. The continued purity of such water will of course depend on the vigilance exercised in keeping the basin free from pollution. As such basins are ordinarily small this is not a difficult task. Several such wells in a group are usually connected and pumped together, and several such groups, if a sufficient supply is obtainable 
within a small area, would be sufficient to furnish with water a town of some size, or to aid materially in supplying a large city.

In York, Chester, Union, and Abbeville counties there are considerable areas of diabase or diorite that on weathering produce a closegrained clay soil that is abundantly charged with lime and magnesia. The springs and wells of these areas are accordingly of hard water. The use of cisterns is more necessary here than anywhere else in the Piedmont region, and yet they are the exception rather than the rule.

Streams.-Where larger supplies of water for manufacturing plants or town corporations are desired, resort is had in most instances to streams, and a pumping plant is installed to lift the water to a reservoir or standpipe. The streams of the Piedmont region are never perfectly clear except at their headwaters, among the mountain spurs that project from the Appalachians out upon the inner edge of the Piedmont area. The fine red clay soil, so characteristic of the deeplyweathered Piedmont surface, is washed into the streams in great quantities by every rain, and the waters become exceedingly muddy. So finely divided are some of these clay particles that they remain suspended indefinitely, and even with prolonged settling it is difficult or impossible to get the water perfectly clear. The excessive muddiness disappears very soon after the passage of a flood, but even in their lowest stages the Piedmont streams do not become perfectly clear. When they are used for city water supply, ample settling basins must be provided or a filtration plant must be installed. The clay is suspended in the water in particles so fine that it can be removed with dificulty even by filtration.

The most inviting sites for the location of towns in the Piedmont region have been the comparatively level interstream areas that form the divides between the main streams, and, as a rule, the principal towns of the region are both remote from and at a considerable elevation above the larger streams, thus occupying situations that greatly increase the cost of water supplies derived from such sources.

Furthermore, with the rapid growth of large cotton mills along these Piedmont streams, each with its attendant mill village in which the sanitation and the sewerage system are usually not what they should be, the problem of obtaining unpolluted water supplies from the streams of this region will constantly become more difficult.

With the growth of larger cities in the Piedmont area, however, other sources must in time become inadequate and the large streams must furnish the water supplies. Means must then be taken to provide sufficient settling area or adequate filter plants as well as to guard the watersheds of the catchment area from organic pollution. These water-supply problems are not different from those other communities have to face except, perhaps, as to the almost permanent suspen- 
sion of the very fine clay particles, and can be successfully solved here just as they have been elsewhere.

\section{COASTAL PLAIN.}

The Coastal Plain attains a width of nearly 150 miles. The average elevation of its inner edge where it overlaps the Piedmont crystallines is about 500 feet. The slope of the surface from the inner edge toward the coast is at first rather steep, so that 30 miles from its inner edge the average elevation has decreased to less than 200 feet. From this line to the sea the surface slope is very gentle. Much of the outer part of the Coastal Plain is low and swampy and the rivers crossing the region are usually fringed with swamps that are in places 5 to 10 miles wide.

The inner, more elevated portion of the Coastal Plain is deeply trenched by the rivers that enter it from the Piedmont region, and much of its surface has been cut into hills by the tributary streams that drain it. An inner belt of these hills is known as the sand hill belt; an outer interrupted belt that is in places more broken and hilly than the preceding one is known as the red hill belt.

GEOLOGY.

Crystalline floor.-Along the outer edge of the Piedmont Plateau the surface of the crystalline rocks dips southeastward and passes beneath the overlapping sands and clays of the Coastal Plain. From well records something has been learned of the depth of the crystalline floor beneath the surface of some parts of the Coastal Plain; but much more information is desirable concerning its depth, especially beneath the central and southwestern parts. At Aiken a boring, after passing through 465 feet of sands and clays, reached granite at 62 feet above sea level. At Florence 608 feet of Coastal Plain sediments overlie the rocks of the Newark formation, which were reached at 473 feet below sea level. At Marion a boring that passed through 700 feet of sands and clays entered crystalline schists 632 feet below sea level. At Wilmington, N. C., a well started only a few feet above tide entered granite at a depth of 1,109 feet. At Orangeburg a well 1,160 feet deep had not reached the crystallines, but was probably not far above them. A well at Charleston 2,050 feet deep and one at Beaufort 1,640 feet deep failed to reach the underlying crystallines.

General character of deposits.-The Coastal Plain formations consist of fine gravels, sands, clays, marls, and an occasional soft limestone. The dip of the lower members is southeastward at a rate somewhat greater than the surface slope. The higher members, however, thicken seaward until the youngest members, or those at the top, dip at the same rate as the surface.

Potomac formation.-The oldest of these members is the Potomac. It lies immediately upon the crystallines, and along its outcropping inner edge consists of at least 400 or 500 feet of variegated sands and 
clays. Much of the sand is coarse and cross-bedded, and usually contains a considerable amount of arkose. The clay is in very irregular lenticular masses embedded in the sands and does not form continuous and persistent strata. These sands and clays outcrop in the sand hills and in part of the red hills along the inner edge of the Coastal Plain in a belt 5 to 10 or more miles wide, where they receive the supplies of water that they carry seaward with them beneath the later members of the Coastal Plain series. These Potomac sands and clays are waterbearers under very much, if not all, of the Coastal Plain; but very little is known as to their exact depth beneath the surface in much of the region. A 1,160-foot well at Orangeburg had probably reached nearly to their base. At Florence they extend from 200 or 300 feet to 607 feet. At Charleston the 2,050-foot well probably stopped in their upper portion. It is probable that the 1,640 -foot well at the naval station at Port Royal had just about reached their top layers, and it is likely that a supply of good water might have been obtained in these Potomac sands within the next few hundred feet had the well not been abandoned where it was. The water found in the deeper-lying portions of the Potomac under the outer part of the Coastal Plain may, however, be found charged more or less with mineral matter, although the water from the deep wells at Charleston is reported to be of excellent quality and furnishes the city's supply.

Marine Cretaceous beds.-The marine Cretaceous is the next younger formation. It consists of dark, unctuous, fine-grained clays, locally known as fuller's earth, and often described by the drillers as soapstone, interbedded with fine, light-colored micaceous sands. The clays contain abundantly disseminated iron pyrite that readily decomposes and gives rise by further reaction to alum, so that open wells and springs in these clays are sometimes very astringent. These Cretaceous clays outcrop only in the eastern part of the State. They do not form the general surface even here, but are overlain by a thin mantle of younger deposits, and are revealed only in stream cuttings along the Pedee and its tributaries. The best exposures are in Darlington and Florence counties. West of Lynches River the marine Cretaceous is not known to outcrop at the surface. There the Eocene rests directly on the Potomac.

From its surface exposures in the eastern part of the State the marine Cretaceous dips southeastward beneath later deposits, and is reached or passed through in the deeper wells of that region. It extends from about 600 to about 1,900 feet in the Charleston wells. It was passed through in the Orangeburg well, its top being about 252 feet from the surface, and its bottom being indeterminate from the record obtained. The Port Royal well from 700 or 800 to about 1,600 feet is in the marine Cretaceous. Well records show that it consists of sands, marls, and dark clays, the latter sometimes described as very tough and sticky to drill. The layers of sand occupy no definite horizon. They are usually 
water-bearing, but the water is often charged with sulphur or iron or is brackish or salt. No persistent horizon of potable water is known in this series. Some of the sandy strata may, however, locally contain good water, and careful tests for quantity and quality of water should be made at any promising horizon.

Eocene deposits. - The Eocene overlies the Cretaceous. In the eastern part of the State, where the Cretaceous is exposed in stream cuttings, a few thin, isolated patches of Eocene are found resting in depressions in the Cretaceous surface. West of Lynches River the Eocene rests directly on the Potomac, and in Orangeburg, Lexington, and Aiken counties numerous exposures of it occur. At the base it consists of fine, light-colored siliceous clay, breaking with conchoidal fracture, and overlain by a silicified mass of shells and casts-the Buhrstone. Above it are soft gray to white pulverulent, calcareous marls, whose lower part is known as the Santee marls, and whose upper part is the Ashley and Cooper marls. They may be grouped together here. These Eocene strata are probably 500 feet thick at Charleston and occupy a basin called the Charleston basin, delimited to the northeast by the marine Cretaceous strata, which come to the surface in the Pedee region, but are of unknown extent to the southwest in Georgia, though they rise considerably in Barnwell County.

The Buhrstone division of the Eocene is more or less cavernous and is generally water bearing. The waters, as might be expected, are more or less hard. They are reached at Charleston at about 400 to 500 feet from the surface. At Orangeburg the base of these rocks is probably about 252 feet from the surface. In Bamberg, Barnwell, Colleton, and Hampton counties they seem to be widespread water bearers and are reached at depths of about 100 feet in upper Barnwell, but dip toward the coast so that there they are found at 500 to 700 feet from the surface. The basal Eocene is therefore very generally water bearing and lies at moderate depths beneath that large portion of the Coastal Plain in which the Eocene occurs. No definite water-bearing horizons are known in the overlying Eocene marls. Open wells and springs in these upper beds furnish hard water.

Miocene marl.-A thin stratum of late Miocene shell marl rests in many places on the eroded surface of either the Eocene or, in the Pedee region, the marine Cretaceous. It is not usually widely continuous and is not important as a water-bearing horizon. Open wells sunk to it yield hard water. It rarely outcrops, and so produces but few springs.

Lafayette and Columbia sands.--Along the inner and more elevated red hill and sand hill portion of the Coastal Plain there may be discriminated in most cases two thin formations of sand that blanketwise overlie all of the older formations. The older one is usually a hardened, cross-bedded sand, often carrying considerable clay and near the rivers, as they enter the Coastal Plain, contains rounded pebbles 


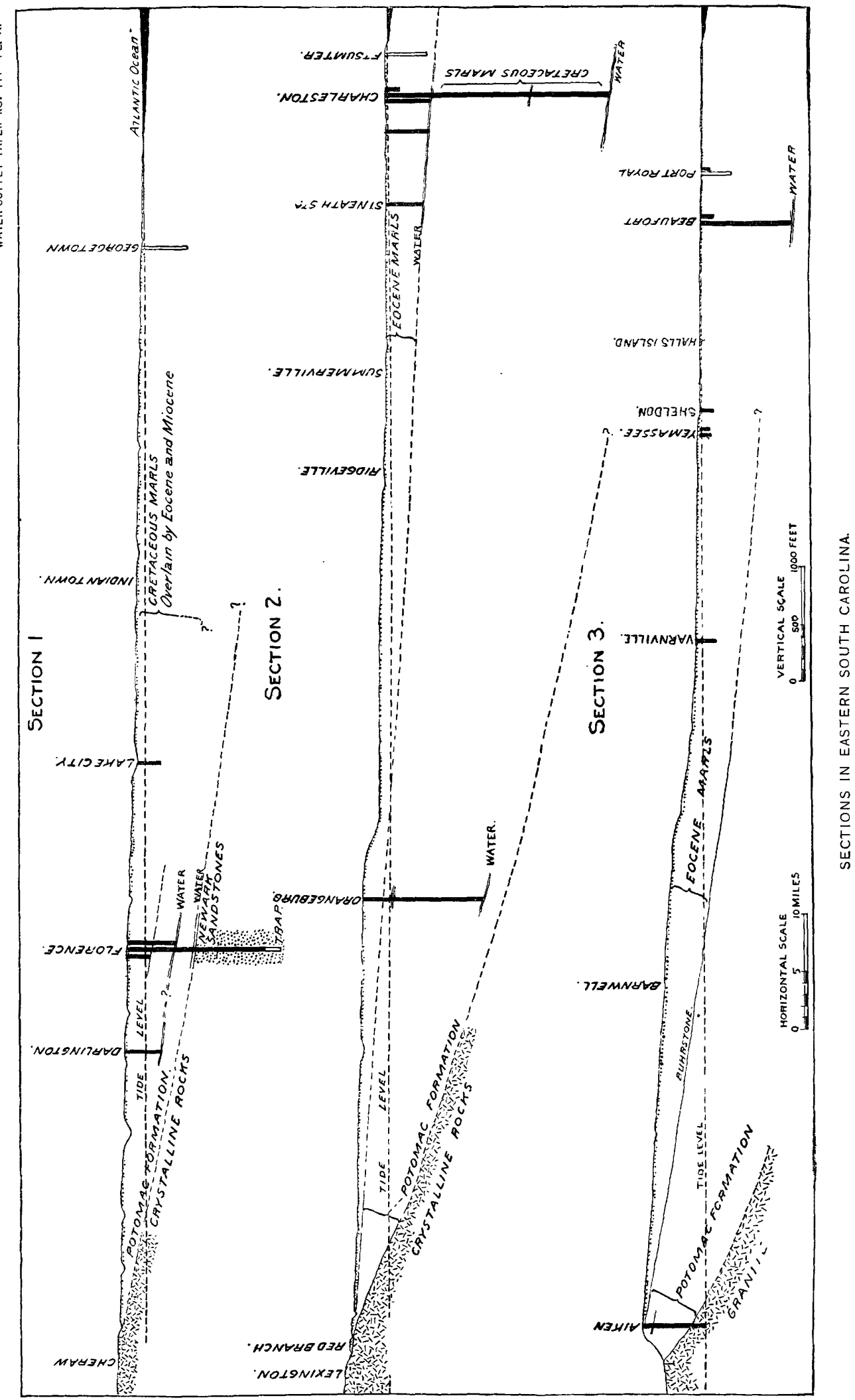


and cobbles. It is regarded as of Lafayette age. Where it overlaps on the Potomac sands and clays it is in many places very difficult to determine the contact line so very similar are their materials, the Lafayette being derived in such cases from the underlying Potomac by a slight reworking. These Lafayette sands and clays are usually red in color. In Columbia they are homogenous, structureless, and bright red. In many places they are mottled red and light gray. They form much of the surface in the "red hill" belt. In the middle and outer half of the Coastal Plain the Lafayette has not been discriminated. If ever present in the outermost part, just near the present coast line, it has very probably been removed by erosion, for the postPliocene rests on rounded phosphate nodules that cover the surface of the Eocene or Miocene marls from which they were torn by the waves.

The younger of the two blanketing formations is a light-colored, soft, clean-washed, barren sand that forms the surface of most of the Coastal Plain, including the sand hills. In the middle and outer part of the Coastal Plain it is usually mixed with enough clay to form a loam. In thickness it ranges from a few feet up to perhaps 50 feet in some places near the coast. It is regarded as of Columbia age, but such distinctions as high-level and low-level or fluvial and interfluvial seem inapplicable to it. Its relation to the post-Pliocene deposits indicates that the portion near the coast, at least, is of late Columbia age.

The post-Pliocene, which comes between the Lafayette and the Columbia, is found in places along or in a few miles of the coast. It is a thin stratum of sand and shells and is of no special importance as a water bearer.

\section{WELLS.}

The following tables present a comprehensive summary of the results of numerous wells bored in the Coastal Plain of South Carolina. Since the list was nade a consideprable number of new wells have been drilled, but the present table is nevertheless fairly representative:

Partial list of deep wells in South Carolina.a

\begin{tabular}{|c|c|c|c|c|c|}
\hline Locality. & Depth. & $\begin{array}{c}\text { Diame- } \\
\text { ter. }\end{array}$ & $\begin{array}{c}\text { Capacity } \\
\text { perminute. }\end{array}$ & $\begin{array}{c}\text { Height } \\
\text { of water.b }\end{array}$ & Remarks. \\
\hline & Feet. & Inches. & Gallons. & Feet. & \\
\hline Abbeville .................. & 520 & ......... & Many. & -3 & In ancient crystallines. \\
\hline Aiken ........... & 558 & $8-6$ & 50 & -170 & In granite; water also at 543 \\
\hline Bamberg: & & & & & \\
\hline 30 wells. & $65-100$ & & & & In buhrstone. \\
\hline \multirow{4}{*}{5 wells. } & 470 & 2 & 40 & +15 & \multirow{4}{*}{ In Potomae sands. } \\
\hline & 495 & 2 & 35 & +20 & \\
\hline & 520 & 2 & 35 & +12 & \\
\hline & 555 & $1 \frac{1}{4}$ & 40 & +30 & \\
\hline
\end{tabular}

$a$ Darton, N. H., Artesian-well prospects in the Atlantic Coastal Plain region: Bull. U. S. Geol. Survey, No. 138, pp. 210-211; also records collected by the writer.

$b+$, teet above surface; --, feet below surface. 
Partial list of deep wells in South Carolina-Continued.

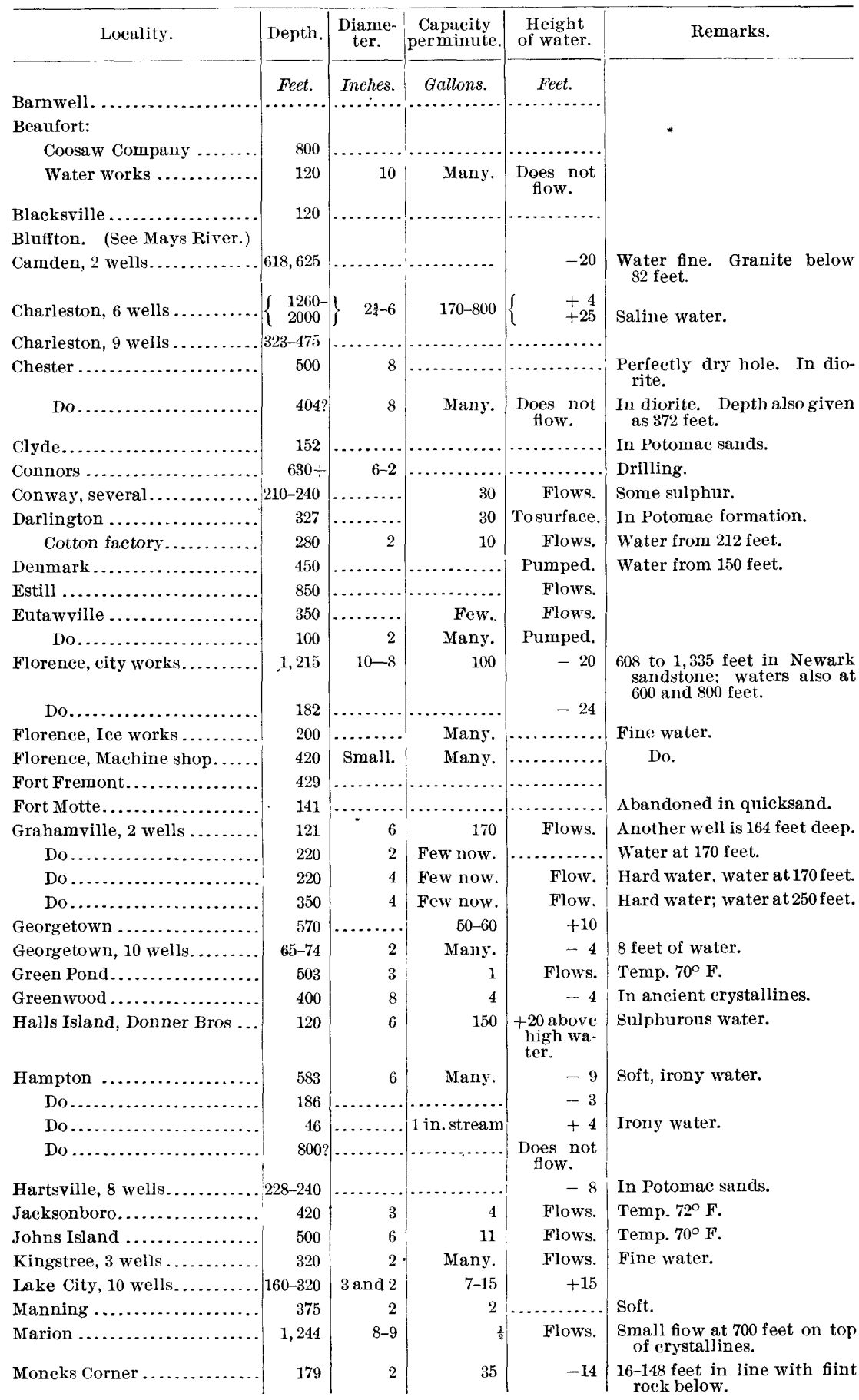


Partial list of deep wells in South Carolina-Continued.

\begin{tabular}{|c|c|c|c|c|c|}
\hline Locality. & Depth. & $\underset{\text { ter. }}{\text { Diame- }}$ & $\begin{array}{c}\text { Capacity } \\
\text { per minute. }\end{array}$ & $\begin{array}{l}\text { Height } \\
\text { of water. }\end{array}$ & Remarks. \\
\hline & Feet. & Inches. & Gallons. & Feet. & - \\
\hline $\begin{array}{l}\text { Moncks Corner, } 8 \text { miles dis- } \\
\text { tant. }\end{array}$ & 175 & 2 & 15 & Flows. & \\
\hline Mays River, Bluffton..... & 165 & $\cdots$ & Many. & & \\
\hline $\begin{array}{l}\text { Mays River, Capt. T. R. Hay- } \\
\text { ward's place. }\end{array}$ & 800 & & Fair. & -1 & Very sulphurous water. \\
\hline $\begin{array}{l}\text { Mays River, Col.J. H. Estill's } \\
\text { place. }\end{array}$ & 190 & & Many. & $\cdots$ & Sulphurous water. \\
\hline $\begin{array}{l}\text { Mays River, Col.J.H. Estill's } \\
\text { plantation, } 4 \text { wells. }\end{array}$ & 360 & & Many. & Flows. & Fine water. \\
\hline $\begin{array}{l}\text { Mays River, Snyder \& Mit- } \\
\text { tle's sawmill. }\end{array}$ & 106 & . & Many. & Flows. & Do. \\
\hline Newberry . & 285 & & & $\begin{array}{l}\text { Nearly to } \\
\text { surface. }\end{array}$ & In granite. \\
\hline Oakley Depot . & 299 & 2 & Many. & $\begin{array}{l}\text { Does not } \\
\text { flow. }\end{array}$ & Fine water. \\
\hline Orangeburg, 4 wells. & 1,160 & & Many. & -48 & Much water at 250 feet. \\
\hline Ousley ....... & 380 & & Not any. & 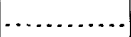 & In Potomac sands. \\
\hline Palmetto ....... & 346 & 2 & 6 & $\begin{array}{l}\text { Nearly to } \\
\text { surface. }\end{array}$ & \\
\hline Peeples. ..... & 853 & 6 & 100 & Flows. & Temp., $76^{\circ} \mathrm{F}$. \\
\hline Port Royal N & 255 & 6 & Very few. & $\begin{array}{l}\text { Does not } \\
\text { flow. }\end{array}$ & Water very impure. \\
\hline $\begin{array}{l}\text { Port Royal Naval Station, } 3 \\
\text { wells. }\end{array}$ & 60 & 5 and 2 & Many. & $-12-16$ & Water hard and saline. \\
\hline $\begin{array}{l}\text { Port Royal Naval Station, } 2 \\
\text { wells. }\end{array}$ & $95-98$ & 6 & 125 & Pumped. & Good water. \\
\hline Do........................ & 1,640 & $15-4$ & & .... & $\begin{array}{l}\text { Abandoned in Cretaceo } \\
\text { clays. }\end{array}$ \\
\hline Rowesville... & 185 & 3 & $\cdots$ & -6 & Hard water. \\
\hline St. Matthews, 5 wells.. & $75-135$ & 3 & 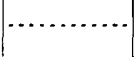 & $\begin{array}{l}\text { Do not } \\
\text { flow. }\end{array}$ & Excellent water. \\
\hline Scranton & 170 & 2 & $\cdots$ & Flows. & \\
\hline Seabrook .............. & 120 & 6 & 150 & +12 & A little $\mathrm{H}_{2} \mathrm{~S}$. \\
\hline Shelden ............... & 152 & 3 & Many. & $\begin{array}{l}\text { Does not } \\
\text { flow. }\end{array}$ & On high land. \\
\hline $\begin{array}{l}\text { Sullivans Island, Fort Moul- } \\
\text { trie. }\end{array}$ & 1,308 & 12-3 & 10 & Flows. & $\begin{array}{l}\text { Temp., } 89^{\circ} \mathrm{F} \text {. Contains iron } \\
\text { and soda. }\end{array}$ \\
\hline sumter .................. & 128 & 2 & 2 & Flows. & Soft water. \\
\hline Swansea............ & $100 ?$. & & & & \\
\hline Union & $300+$ & & & ...... & Drilling. In granite. \\
\hline Varnsville...... & $988 ?$ & 6 & Many. & -17 & \\
\hline Walterboro ............... & 490 & 6 & Many. & -30 & Soft water. \\
\hline Wedgefield .............. & 580 & $3-2$ & ........ & -90 & Not used. \\
\hline Williston, L. Green........... & 130 & 3 & 5 & ….. & \\
\hline Yemassee, G. G. Martin ...... & 90 & $4 \frac{1}{2}$ & Many. & $\begin{array}{c}\text { Flows to } \\
+13 .\end{array}$ & Sulphurous water. \\
\hline $\begin{array}{l}\text { Yemassee, J. B. Gregorie, } 8 \\
\text { wells. }\end{array}$ & $85-150$ & 6 & Many. & +8 & $\begin{array}{l}\text { Sulphurous water; flow de } \\
\text { creasing. }\end{array}$ \\
\hline
\end{tabular}

\section{SUMMARY OF COASTAL PLAIN SUPPLIES.}

Shallow wells.-The shallow wells of the Coastal Plain are sunk in the surficial Lafayette and Columbia formations. These wells are usually not over 20 or 30 feet deep. Many, indeed, are from 8 to 12 feet deep, and in wet weather many of them are entirely full of water. Such surface water is as a rule impure and unwholesome, especially if the wells be open. Driven wells are now largely taking the place of 
open wells. A 2-inch pipe tipped by a sharp-pointed strainer section is driven from 15 to 30 feet, and a small suction pump is attached to the upper end. Such wells are quickly, easily, and cheaply driven, and do not permit surface waters to trickle down directly from the surface, as do the open wells. Their waters are more wholesome than those of open wells, but their general use will not solve the pure-water problem for the Coastal Plain.

Deep wells.-Many farmers are sinking artesian wells of small diameter and moderate depths to the upper part of the Potomac beds in the inner half of the Coastal Plain, while on the outer half wells are bored deeper with somewhat less certainty of getting good water from the lower Eocene. Unfortunately, very few records that give much information as to the age or kind of beds passed through have been kept by the drillers or owners, so that our knowledge of the underground waters of the region leaves much still to be desired. Experience, however, has proved that in many parts of the Coastal Plain the chances for obtaining supplies of deep water that will rise nearly to or just above the surface are excellent. In other parts, especially very near the coast, the problem is more uncertain because of the great depth of the water-bearing strata and the greater risk of finding the water too highly impregnated with various mineral matters to be usable. Numerous good wells, however, have been drilled near the coast, and drillers in this region should carefully test every water-bearing sand of any promise as they go down.

The use of artesian water has greatly improved the health conditions on the Coastal Plain. Not only has typhoid fever been banished, but of greater importance, because of its former more general prevalence, malaria has been practically banished also, despite the presence of mosquitoes.

Streams.-The streams of the flatter portions of the Coastal Plain are dark wine-colored from the presence of organic matter. Those in the sand hills are usually pure and clear and may be used for bleaching or for any other similarly exacting purpose for which a very pure, clear water supply is necessary. The sand hills yield their underground waters very gradually and regularly to the streams, so that stream discharge in this region is very uniform.

\section{PRINCIPAI PUBLICATIONS.}

Mineral springs of the United States, by A. C. Peale: Bull. U. S. Geol. Survey No. 32 , pp. 79-80.

Artesian-well prospects of the Atlantic Coastal Plain region, by N. H. Darton: Bull. U. S. Geol. Survey No., 138, pp. 207-222.

Preliminary list of deep borings in the United States, pt. 2, by N. H. Darton: Water-Supply and Irrig. Paper U. S. Geol. Survey No. 61, p. 43.

Year Book, City of Charleston, 1881, pp. 257-315. 


\section{GEORGIA.}

\section{By S. W. MoCallie.}

Georgia may be divided into three great provinces-the Coastal Plain, the Piedmont Plateau, and the Appalachian or Paleozoic areaeach of which represents a great time division of geologic history.

\section{COASTAL PLAIN.}

The Coastal Plain includes that part of the State lying south of an irregular line connecting Augusta, Macon, and Columbus, and comprises more than one-half of the entire State. In this region the rocks are Cretaceous and Tertiary clays, sands, and soft limestones, having a general dip southward of only a few feet to the mile. The sands and limestones usually furnish copious supplies of water, which in some instances has sufficient head to be used for irrigation purposes and to operate machinery. The waters from the Cretaceous beds are usually soft, but those from the Tertiary are frequently hard and unsatisfactory for many purposes.

In addition to the underlying Cretaceous and Tertiary formations two surficial formations - the Lafayette and the Columbia-are of especial importance in connection with the water supply of shallow wells. These formations consist of clays and sands, and cover more or less completely the entire Coastal Plain. The Lafayette, the older of the two, lies unconformably on the Cretaceous or Tertiary rocks. It consists of orange and vari-colored sands and clays with local beds of gravel. Overlying the Lafayette is the Columbia formation, which is made up almost entirely of rather fine-grained sand, and in places attains a thickness of many feet, but more often is much thinner, or is entirely wanting. These two surficial deposits are the main sources of the water supplying the shallow wells throughout the Coastal Plain, and they also govern the amount of rainfall taken up by the underlying Cretaceous and Tertiary sands and limestones. Where the Lafayette formation consists largely of clay it forms an impervious water-bearing stratum which to some extent prevents rainwater from penetrating the underlying Cretaceous or Tertiary deposits. On the 
other hand, the Columbia sands absorb a large percentage of the rainfall, which is retained until taken up by the underlying deposits. These surficial formations either increase or decrease the water supply in deep wells according as they take up little or much of the rainfall.

\section{PIEDMON'T AREA.}

The Piedmont Plateau, or crystalline area, embraces all of that part of the State lying north of the Coastal Plain with the exception of the greater part of ten counties in the northwestern portion.

This region is an old eroded land surface, formed of highly metamorphosed igneous and sedimentary rocks, which are frequently weathered to considerable depths. The prevailing rocks are slates, schists, gneisses, and granites, none of which can be considered water-bearers of any great promise. The crystalline area is noted for the numerous small springs that are rather evenly distributed throughout it. There are a few large springs, but they are rare and are usually due probably to the presence of faults rather than to any special waterbearing strata. The deep weathering of the rocks is favorable to a copious supply of water for shallow wells. Nearly all of the small towns are supplied by such wells, which, except during an extremely dry season, furnish an abundant supply of what is generally supposed to be very wholesome water. Deep wells have been drilled by some of the towns, but in the majority of cases the amount of water secured has been inadequate to supply the demand. Furthermore, the geologic structure of the crystalline area is such that water obtained from deep borings is likely to become contaminated sooner or later from surface drainage, especially where there is little or no sandy soils to act as a filter, and where the upturned edges of the rocks dip at a high angle.

\section{APPATACHIAN OR PALEOZOIC AREA.}

The Paleozoic area comprises the greater part of ten counties in the extreme northwestern part of the State. The rocks of this region are limestones, shales, and sandstones, thrown into a number of long parallel anticlinal and synclinal folds. The anticlinal folds in many cases have been decapitated and are now replaced by valleys of erosion, while the synclines form the intervening ridges or mountains. These structural conditions are usually unfavorable for flowing wells, but at the same time they materially allow the rainfall to be rapidly absorbed by the upturned edges of the strata. They also explain the distribution of the numerous springs.

The water-bearing strata of the Paleozoic area are the limestones and the sandstones. The limestones, from which most of the underground water is obtained, are usually heavy bedded and compact. The water contained in them frequently occurs in deep fissures or channels as running streams of considerable size. 
When these strata outcrop such streams give rise to huge springs, which furnish large volumes of water, and which often occur throughout the Paleozoic area. The largest of these springs are generally found along fault lines or near the contact of limestones with impervious shales. The water from these large springs often becomes muddy after a heavy rainfall, showing that the underground stream which supplies them with water has direct connection with limesinks or other open cavities on the surface. Such springs are also more or less affected by droughts, and have been known to entirely cease flowing during an extremely dry season.

The sandstones of the Paleozoic area which are here spoken of as water-bearing strata are confined chiefly to Sand and Lookout mountains. At several points on these mountains the bore holes put down in prospecting for coal have furnished rather copious supplies of water. The numerous coal mines located on these mountains also demonstrate that the sandstones are water carriers of considerable importance. In northwest Georgia are also very favorable conditions for shallow wells. The residual clays are generally of such thickness as to retain a high percentage of the rainfall within a short distance of the surface and supply shallow wells with ample water for all domestic purposes.

\section{UNDERGROUND WATER CONDITIONS.}

The geologic conditions bring out prominently marked differences in the underground water conditions of the different parts of the State. In south Georgia, or the Coastal Plain, the numerous beds of sand and porous limestones with their gradual dip southward present favorable conditions for deep wells. In the crystalline and Paleozoic areas, where the formations are much folded and faulted, underground water reaches the surface by numerous springs. In the one case the deep-seated underground waters reach the surface through artificial openings made by the drill, and in the other they come up through open fissures or along bedding planes of the rock. In the first case the underground waters are far more liable to become contaminated by surface impurities than in the other. This is due to the high or steep dip of the water-bearing strata. In south Georgia the underground waters in most cases probably flow through several miles of porous limestones or sands before reaching the deep wells, but in the northern part of the State wells equally as deep may be supplied with water falling as rain only a few hundred yards distant.

The conditions governing the water supply of shallow wells are practically the same in all parts of the State, especially where the wells obtain water from surficial deposits and residual clays.

The water from the shallow wells supplying small towns in north Georgia was usually found to be in fair sanitary condition, but in a IRR $114-05-11$ 
few instances analyses made in the laboratory of the State geological survey gave unmistakable evidence of sewage contamination. Certain local geologic conditions, which are peculiar to the northern portion of the State, seem to be the cause of this contamination. They will be described somewhat in detail.

All of the rivers and large streams throughout the crystalline and the Paleozoic areas traverse valleys of erosion which vary in width

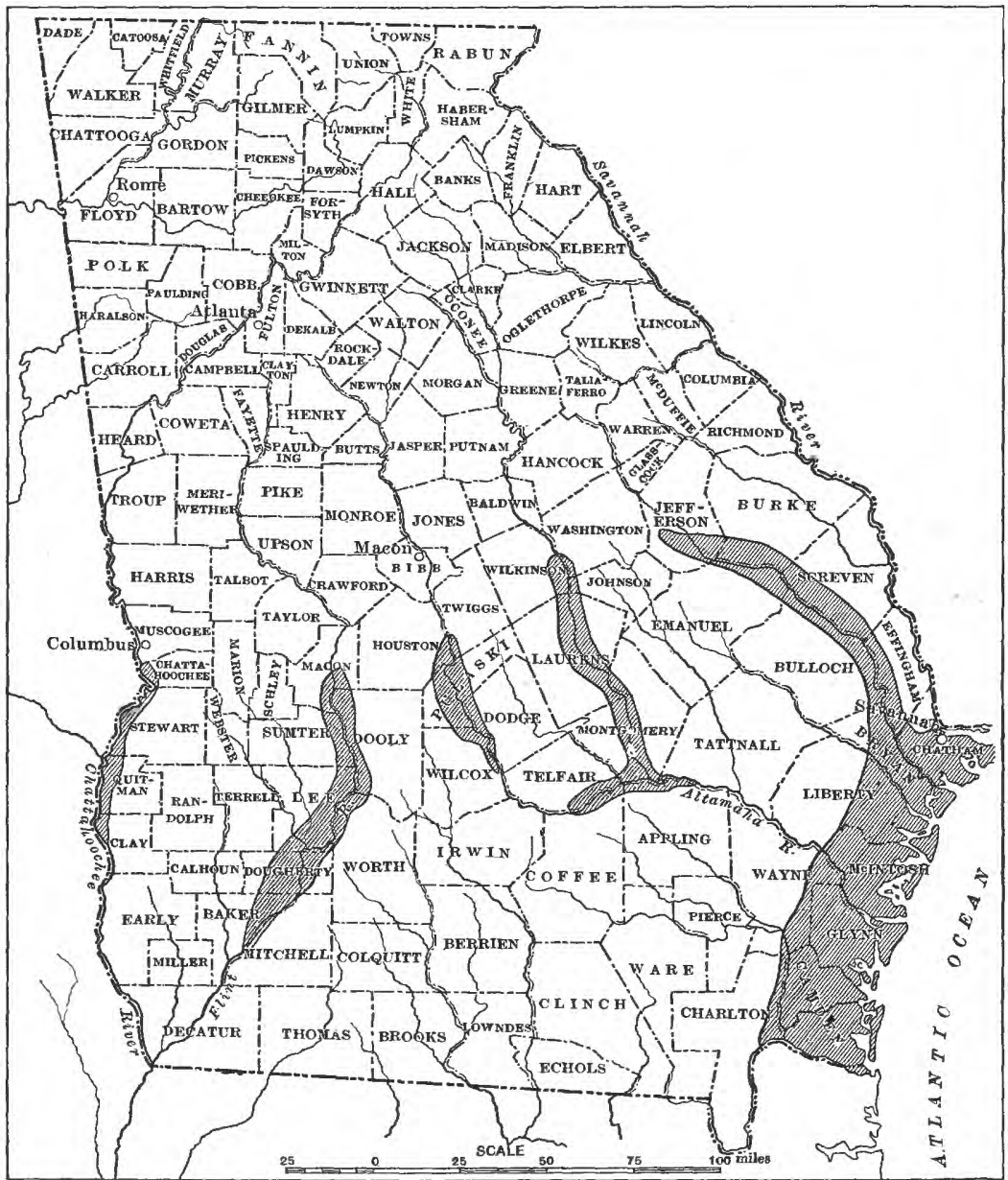

FIg 21.-Areas of flowing wells in Georgia. Flowing wells may be obtained in shaded areas.

from a few hundred yards or less to a mile or more. These valleys, parts of which now lie several feet above the present flood plain of the river, are often covered to the depth of many feet with alluvial deposits left by the stream when it flowed at a higher level. The deposits usually occur in two layers. The lower layer, which lies directly upon the eroded edges of the underlying rocks, consists 
chiefly of coarse waterworn gravel and rounded stones, the latter often attaining a weight of many pounds. The thickness of this layer is variable and depends somewhat upon the irregular eroded surface of the underlying rock, but generally it is from 10 feet to a few inches. The upper layer, which is usually much thicker than the lower, is made up largely of silt or sandy clays. The two layers are conformable and have the same dip as the eroded surface of the underlying rock. This gives to the entire surficial deposit a gradual slope toward the center of the valley or the present channel of the stream. In many places the upper of the two surficial beds has been removed by erosion along the edges of the valley so that the underlying gravel is exposed. These exposed edges of the gravel beds present most favorable conditions for taking up the surface waters as they escape from the adjacent hillsides to the valley below after hard showers. These beds form a very imperfect filter and, as a consequence, the well water obtained from them is liable to become contaminated by surface impurities.

In north Georgia some of the towns along the rivers depend for water supply almost entirely upon surface wells penetrating these gravel beds. In laying out such towns it has been the custom to locate the business houses and the residences near the center of the valley, and the barns and stables along the margin near the outcrop of the gravel beds. In one town a row of factory houses was built along the outcrop of these gravel beds and there was an epidemic of typhoid fever throughout the town. Another town where the well waters were contaminated had suffered from a most violent epidemic of typhoid fever a few years previous. With a comparatively small outlay all of these towns can be supplied with excellent water from the mountain streams.

\section{MINERAL SPRINGS.}

Ten springs in Georgia reported sales of water in 1902. The total amount sold was 419,100 gallons, valued at $\$ 60,797$. The springs are as follows:

Artesian Lithia Well, Austell, Cobb County.

Bowden Lithia Springs, Lithia Springs, Douglas County.

Catoosa Springs, Catoosa County.

Daniel Mineral Spring, near Union Point, Greene County.

Hughes Mineral Springs, near Rome, Floyd County.

Medlock Lithia Springs, Austell, Cobb County.

Ponce de Leon Spring, near Atlanta, Fulton County.

Salt Spring Lithia Well, Austell, Cobb County.

Siloam Healing Springs, near South Atlanta, Fulton County.

Sulpho-Magnesia Lithia Spring, near Austell, Cobb County. 


\section{PRINCIPAL PUBLICATIONS.}

Mineral springs of the United States, by A. C. Peale: Bull. U. S. Geol. Sirvey No. 32 , pp. $81-85$.

Artesian-well prospects of the Atlantic Coastal Plain region, by N. H. Darton: Bull. U. S. Geol. Survey No. 138, pp. 222-224.

Preliminary list of deep borings in the United States, pt. 1, by N. H. Darton: Water-Supply and Irrig. Paper U. S. Geol. Survey No. 57, pp. 22-24.

Preliminary report on the artesian-well system of Georgia, by S. W. McCallie: Bull. Georgia Geol. Survey No. 7, 1899.

Georgia [well and spring records and town water sapplies], by S. W. McCallie: Water-Supply and Irrig. Paper U. S. Geol. Survey No. 102, 1904, pp. 207-237.

Experiment relating to problems of well contamination at Quitman, Ga., by S. W. McCallie: Water-Supply and Irrig. Paper U. S. Geol. Survey No. 110, 1905, pp. 45-54. 


\section{FLORIDA.}

By M. L. Fuller.

Florida, unlike any other State except Louisiana, lies wholly within the Coastal Plain, although Delaware and Mississippi include only very small areas of older rocks. While in both geology and topography it resembles certain portions of the Coastal Plain region in other States, it is, as a whole, unique in its characteristics.

\section{TOPOGRAPHY.}

The relief of Florida is the lowest of any of the Eastern States, only about a quarter of its area standing above the 100-foot level, while only a few isolated points exceed 200 feet in height. Starting in the western portion of the State the highland belt skirts the northern boundary to Tallahassee, beyond which it extends southward along the center of the peninsula to a point east of Tampa. Its eastern border stretches northward a few miles west of St. Johns River to the northern boundary of the State northwest of Jacksonville. In this region soft limestones occur extensively, and there are, especially in the peninsula, many sinks and depressions, which are frequently occupied by ponds, lakes, or marshes. It is the gathering ground of the flowing waters encountered in the wells nearer the coast. On each side of the highlands the land slopes toward the coast, becoming at the same time freer from sinks and similar irregularities, but more or less cut by stream channels. Along the coasts on both sides of the southern portion of the peninsula are numerous low-lying islands or reefs of coral, shell fragments, or other material. The interior of the southern portion of the peninsula is occupied largely by vast swamps, of which the Everglades is the most extensive and best known.

The population is largely confined to the highlands. There are a few eities and villages near the Gulf coast west of the Tallahassee region and a considerable number about Tampa Bay. The Gulf coast is otherwise thinly inhabited. On the Atlantic side there is a line of villages and towns along the coast, but south of Titusville the interior is largely uninhabited. Key West and a few villages and towns are located on the keys and islands. 


\section{GEOLOGY. $a$}

The axis of the peninsula of Florida consists largely of rotten cavernous limestone, white, gray, or yellow in color and of the Tertiary age. The main belt of these beds extends from the vicinity of Taylor, Madison, and Suwanee counties southeastward to Pasco County and vicinity. On the west the Lower Oligocene limestones are separated from the coast by a strip of Upper Oligocene beds, consisting of somewhat harder and more massive limestones with occasional beds of clay. The Upper Oligocene beds extend northwestward parallel with the Gulf shore to the western limits of the State. On the east the Lower Oligocene belt is limited by Octawaha River, beyond which are beds of Miocene age which extend nearly or quite to the coast. Toward the west a strip of Miocene parallels the coast, lying south of the Upper Oligocene, from at least Ochlockonee River on the east to Apalachicola River on the west. In the southern portion of the State the surficial rocks are of late Tertiary age, mainly Pliocene, and consist of marls, gray, green and blue clays, soft limestones, shale beds, etc. In the central part of the northern portion of the peninsula great thicknesses of sands, mainly of Quaternary age, cover the older rocks, while along the northern boundary in the western part of the State occurs the southern edge of the mantle of yellow sands, etc., generally known as the Lafayette formation. Local deposits of coquina and other late Pliocene and Quaternary materials occur at a number of points near the coast. The structure of the peninsula is supposed to be anticlinal, and the occurrence of artesian water would appear to bear out the assumption. Except along the belt of Lower Oligocene limestones, where the land rises to an elevation of about 250 feet, and in a few of the sand hills the region is very low.

\section{UNDERGROUND WATERS.}

Highland area.-Along the northern border of the State and in the highlands extending southward along the center of the peninsula the elevation of the surface generally precludes flowing wells, the region being one of catchment rather than of discharge. There is, nevertheless, frequently a range of 75 feet or more in the local elevation of the surface in this region, and flowing wells are not uncommon. They depend, however, mainly on local conditions, artesian areas of any extent being absent. The waters seldom rise more than 10 feet above the surface even when the wells are located in the lowest depressions. Fairly good water may be obtained in most instances from drilled wells of moderate depth, but generally pumping has to be resorted to. 
Many of the depressions and channels of the highland area are marked by springs, some of which have been developed as resorts, while the waters of others are placed on the market for medicinal purposes. The springs are numerous and frequently of large size, giving rise, as in the case of Silver Springs, to streams navigable to their source. The waters, though hard, generally contain little sulphur and iron in solution.

West coast.-From the highland area the surface gradually slopes

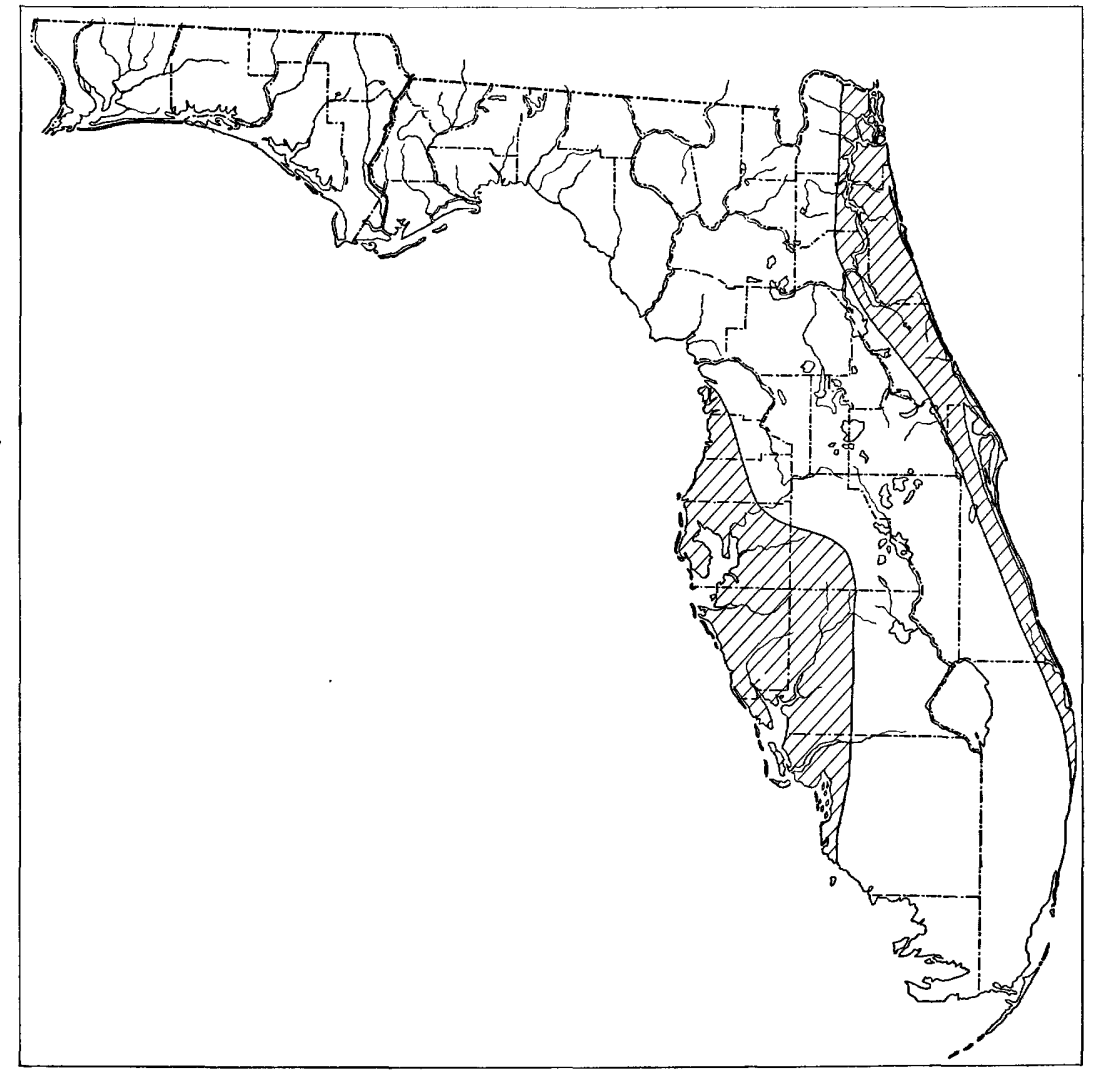

FIG. 22,-Principal artesian areas of Florida.

westward and southward to the coast. The area, as a whole, is very thinly settled, and relatively few wells have been drilled. In Hillsboro and Manatee counties, bordering upon Tampa Bay, and in the region extending into Polk County on the east, there is a considerable number of flowing wells. Flowing water is also found occasionally from Perry County westward to the western limits of the State, and it is probable that it could generally be obtained if the region was thoroughly tested. The land, however, is relatively low and ill adapted 
to settlement, and, moreover, contains numerous streams and springs, some of the latter forming streams of considerable size. The waters are generally charged with sulphur and are undesirabie for many purposes.

East coast.-Most of the flowing wells of Florida are located along a strip from 20 to 40 miles in width, following the east coast from the northern boundary of the State southward to beyond Jupiter Point. The wells are most numerous along St. Johns River, which lies but a few feet above sea level and along the so-called Indian River between the main coast and the outlying reefs. The waters frequently rise 10 feet or more above sea level, and in some cases are reported to rise as high as 50 feet, indicating that the waters are derived from the highlands of the interior. This tends to bear out the assumption which has been made as to the arched structure of the rocks of the peninsula. Artesian wells are also found along the reefs and islands, but the shallow wells in such locations are brackish.

The waters from the flowing wells of this belt are extensively utilized for irrigation throughout the entire strip, both on the mainland and on the islands or keys. They are usually obtained at depths of from 200 to 400 feet, but occasionally wells are drilled to great depths. A few very deep wells failed to secure satisfactory supplies.

Springs of considerable volume, generally of sulphur water, are found along St. Johns River and on the coast.

Sand area.-Overlying a considerable area in the north-central part of the peninsula and to a lesser extent elsewhere are extensive deposits of sands of Quaternary age. Throughout this region the ordinary wells are mainly of the driven type. The depth is commonly from 10 to 100 feet, depending largely upon the elevation at which the well is started. The water, though hard, is generally not otherwise mineralized. In most instances it is reported to be satisfactory as regards health, but in some regions is not considered desirable for drinking purposes.

\section{MINERAL SPRINGS.}

In 1902 sales of mineral water were reported by the following springs: ${ }^{a}$

Hampton Spring, Rocky Creek, Taylor County.

Magnolia Springs, Magnolia Springs, Clay County.

Orange City Mineral Spring, Orange City, Volusia County.

Panacea Mineral Springs, Wakulla County.

White Sulphur Springs, White Springs, Hamilton County. 
The aggregate output is reported as 21,900 gallons, with a value of $\$ 8,277$.

\section{PRINCIPAL PUBLICATIONS.}

Florida [well and spring records], by M. L. Fuller and B. M. Hall: Water-Supply and Irrig. Paper U. S. Geol. Survey, No. 102, 1904, pp. 238-275.

Mineral springs of the United States, by A. C. Peale: Bull. U. S. Geol. Survey No. 32 , pp. 85-87.

Preliminary list of deep borings in the United States, pt. 1, by N. H. Darton, WaterSupply and Irrig. Paper U. S. Geol. Survey No. 57, pp. 21, 22. 


\section{ALABAMA.}

\section{By Eugrene Allen Smith.}

\section{CRYSTARIINE SCHISTS.}

Under this head are included both the igneous and the metamorphic sedimentary rocks, which from their close texture are not very permeable, and hence are poorly adapted to absorbing and storing underground waters, but which are very generally covered with a mantle of sandy clays, the result of weathering, which yield an ample supply of water to springs and shallow wells. While the conditions are as a rule unfavorable for obtaining artesian waters, there are two wells at Alexander which yield abundant water but do not overflow.

\section{NONCRYSTALLINE FORMATIONS.}

The noncrystalline formations are found in northeastern Alabama, and together with the crystalline schists cover two-fifths of the State. The constituent strata are sandstones, shales, and limestones, in many alternations and of various degrees of purity. Owing to folding and other movements these strata, with the exception of the Coal Measures, bave a very decided dip, generally toward the southeast. They are not very porous; but the sandstones and conglomerates, when their pores are not too much clogged with argillaceous and calcareous material, are the most permeable.

Springs and shallow wells.-In all the Paleozoic series, and especially in the Carboniferous, the siliceous rocks above mentioned are the sources of springs and shallow wells which yield pure freestone water, holding in solution 12 grains or less of mineral matters, mainly the carbonates of sodium and calcium.

The shales are practically impervious, and where they prevail, as in the flatwoods of the Cambrian in the Coosa Valley above Gadsden, in the central belts of the anticlinal valleys, and in some parts of the coal fields, most of the surface springs go dry in summer and fall months. In some parts of the flatwoods the waters from the shales are charged with mineral salts, especially the sulphates of calcium and magnesium-containing as high as 127 grains to the gallon. From certain 
black bituminous shales of the Devonian containing disseminated pyrites are obtained strong sulphur waters that are known beyond the limits of the State. Such waters occur at Blount, Shelby, St. Clair, Talladega, and Alabama White Sulphur Springs.

The limestones are very generally fissured, channeled, and traversed by caves. Surface springs in limestone are therefore not important, except where they are formed by the emergence of underground streams. The "big springs," or limestone springs, thus originating characterize particularly the Knox dolomite of the Silurian and the lower Eocarboniferous formation. Some of the most noted of these big springs are at Tuscumbia, Huntsville, Montevallo, Talladega, and Jacksonville. The water is always charged with carbonate of lime.

Artesian systems.-The compactness and the steep dip of the rocks in the Paleozoic area do not offer favorable conditions for artesian wells, yet in a few cases deep borings have been successful. Thus at Anniston several wells in Cambrian strata have a depth of 250 to 500 feet, and the water rises nearly to the surface, but does not overflow. The supply is ample for the furnaces for which the wells were bored. On the southeastern slope of Red Mountain, near Gate City, there are four borings which reach depths of $25,85,103$, and 344 feet. From two of these the water overflows; in the others, on slightly higher ground, it rises nearly to the surface.

In the Tennessee Valley, west of the meridian of Huntsville, the Eocarboniferous strata have a moderate southerly dip, and in most of the deep borings the water rises usually to within 30 feet of the surface, as near Sheffield and Russellville. A well near Decatur flows about 10 gallons per minute. This well was bored seventy-five years ago, and there has been no perceptible diminution during this time. In the Coal Measures of the Warrior basin the moderate and uniform dip of the strata is favorable to artesian wells, but the texture of the sandstones and other strata is not. Deep borings about Cullman and Tuscaloosa reach water which rises in the wells and can be pumped. At Jasper a deep well overflowed for some years after it was bored, but does not now.

Several borings in and near Tuscaloosa penetrate the Coal Measures and get a fairly good supply of water which rises in the wells but does not overflow. At the furnace of the Central Coal and Iron Company the well yields 500 gallons per minute. The water contains sodium chloride and the salts of magnesium and calcium.

\section{COASTAL PLAIN.}

In the Coastal Plain region, which includes about three-fifths of the State, the most important rocks are Cretaceous and Tertiary. The Cretaceous overlies the Paleozoic unconformably, and is in turn overlain by the Tertiary. The strata of both series are composed of alter- 
nating beds of sands, clays, and limestones, and have a slight Gulfward dip, which averages 40 feet to the mile. The surface of the country slopes in the same direction, but at a much less rapid rate, the elevation being about 600 feet above tide on the landward margin, and 200 feet in the two coast counties. Thus the lithologic and physical characters, the arrangement, and the gentle uniform southward slope of the component beds provide requisite conditions for artesian systems.

The Cretaceous and Tertiary rocks are covered unconformably by one, and in some places by two, formations of much later date-the Lafayette of Quaternary age and the Grand Gulf of late Tertiary or possibly Quaternary. The Lafayette is far more extensive than the Grand Gulf group, as it covers or has covered the entire Coastal Plain, and sometimes for miles overlaps the Paleozoic area. It was once probably continuous over this region, but it is now much dissected, and has been almost entirely removed on some areas, especially the chalk of the Cretaceous and the post-oak flatwoods of the Tertiary. The Grand Gulf group, on the other hand, is confined to the lower counties. In the western half of this region it overlaps the Miocene and the uppermost (St. Stephens) formation of the Eocene. Toward the east it covers parts of the Claiborne and even of the "Lignitic," and extends to the border of the Cretaceous.'

The underground waters in the Coastal Plain are hence obtained from two sources-the artesian water from older rocks (Cretaceous and Tertiary) and the surface waters from the two surface mantles.

\section{SPRINGS AND SHALLOW WELLS.}

The Lafayette formation, consisting of red sandy loam overlying irregular beds of pebbles and averaging 20 to 25 feet in thickness, is most admirably adapted for absorbing and storing the rainfall. At its contact with the underlying older formations, pure freestone water occurs in springs, and may be made available everywhere by means of shallow wells. As the water percolates through sands and pebbles, it takes in solution a very small amount of mineral matter, generally less than 3 grains to the gallon, of which carbonate of lime is the chief ingredient. Wherever this mantle is found in patches of considerable extent, a never failing supply of the purest water may be counted on, and the country is traversed by perennial streams. However, it does not afford the requisite conditions for artesian systems, (1) because of the great irregularity in the stratification due to erosion and (2) because being a mantle it has a southward dip not greater than the slope of surface.

The Grand Gulf group resembles the Lafayette and underlies it directly wherever the two occur together, but is much more lim- 
ited in distribution and more uniform and regular in stratification. It is therefore well adapted to serve as a water reservoir. Its waters, like those of the Lafayette, are in general exceptionally pure, though sometimes highly charged with dissolved salts, mainly carbonate of lime. In the best of them there are not more than 5 grains of mineral matter to the gallon. Freely flowing springs and perennial streams are not, however, so characteristic of this as of the Lafayette. Shallow ponds and depressions, where the moisture-loving plants constituting the "pine-barren" flora find their most favorable conditions of existence, are typical features of the Grand Gulf territory.

This formation is an admirable cover for artesian waters, because of the thick stratified clays in its upper members. Over a large portion of this region, notably about Brewton and Pollard and other localities in Escambia County, water of good quality flows from borings 100 to 400 feet deep. The water is obtained in part from the Grand Gulf group and in part from the underlying Tertiary beds.

Springs and shallow wells which obtain water from the older formations vary in character. If they have their origin in the great sand formations of the lowermost Cretaceous and of the Tertiary, they are numerous and reliable, though the water is sometimes unpalatable because of much dissolved mineral matter. In the limestone formations of the middle Cretaceous and upper Tertiary, surface waters are small in amount and unreliable, compelling recourse to artesian wells.

\section{ARTESIAN WA'TER SYSTEMS.}

The materials and the structure of the Coastal Plain formations are favorable to artesian wells, as the strata are composed of sands and clays in many alternations, and have a moderate and uniform dip southward.

The two lowermost divisions of the Cretaceous-the Tuscaloosa and the Eutaw-are prevailingly sands, alternating with sheets of clay. The Tuscaloosa is of fresh-water origin, while the Eutaw is a marine deposit. The water obtained from the Tuscaloosa beds holds usually less than 15 grains of dissolved solids to the gallon, mainly the carbonates of lime and sodium, with smaller proportions of sodium chloride and magnesium carbonate. The potable waters of the Eutaw sands, on the other hand, contain from 15 to 30 grains of solid matters per gallon, and the chloride and carbonate of sodium predominate, though occasionally the carbonate of lime is more abundant. Some of these waters are brines, holding as much as 260 grains of sodium chloride to the gallon.

In the area of the Selma chalk which immediately overlies the Eutaw surface waters are practically nonexistant except in wet weather, and recourse must be had to artesian wells or to cisterns sunk in the solid chalk rock. In this section most of the artesian wells obtain water from the Eutaw sands, which are 300 feet thick and in 
which four water horizons are recognized by well borers. The fourth or lowermost is generally the strongest and most reliable, yielding generally flowing water where the altitude is not over 215 feet above tide. In the eastern part of this area, in Russell County particularly, the water sometimes rises to altitudes of 300 feet.

Along the southern border of the chalk, as at Livingston and Linden, artesian borings must traverse the entire thickness of the limestone1,000 feet-before reaching the water-bearing sands. Near the northern border, of course, the borings are much shallower, but here, in order to get a copious and reliable water supply, the borings must frequently go deep into the Tuscaloosa strata underlying the Eutaw. The upper members of the Tuscaloosa contain much purplish or reddish clay, generally referred to by the well borers as the "pink kaolin."

Hundreds of artesian wells supply the plantations of the prairie belt across the State and many cities, among which are Eutaw, Greensboro, Marion, Selma, Demopolis, Uniontown, Montgomery, and Union Springs.

The uppermost of the Cretaceous formations, the Ripley, is formed of calcareous sands which weather at surface into loose sands and are well adapted to collecting and storing surface waters. Springs and shallow wells in consequence generally afford an ample supply of water, which is usually limy. Below the belt of weathering, however, these beds do not appear to be very permeable, as is shown by the failure of most of the deep borings into them.

Near the base of the Tertiary, west of Alabama River, 200 feet of massive clays give rise to the post-oak flatwoods which are characterized by heavy cold soils, defective drainage, and deficiency of springs and surface waters generally during the dry seasons. The shallow wells sunk into these clays give a scanty and unreliable supply of water which is often unfit to drink because of excess of dissolved salts, especially magnesium sulphate, which is sometimes present to the amount of 100 to 210 grains per gallon. Waters of this character from wells near York and Curls, in Sumter County, are extensively used for medicinal purposes. The failure of the underlying Ripley sands to supply good artesian water is a great drawback to the flatwoods territory.

East of Alabama River the prevailing beds near the base of the Tertiary are limestones, wl: $\mathrm{h}$ in Barbour County are of sufficient thickness to give rise to caverns, "Big Springs," and water conditions similar to those of other limestone areas.

In the "Lignitic" group of the Tertiary the alternations of sands and clays and their uniform moderate dip are favorable to artesian systems, and two artesian-water horizons are well known, the Nanafalia and the 


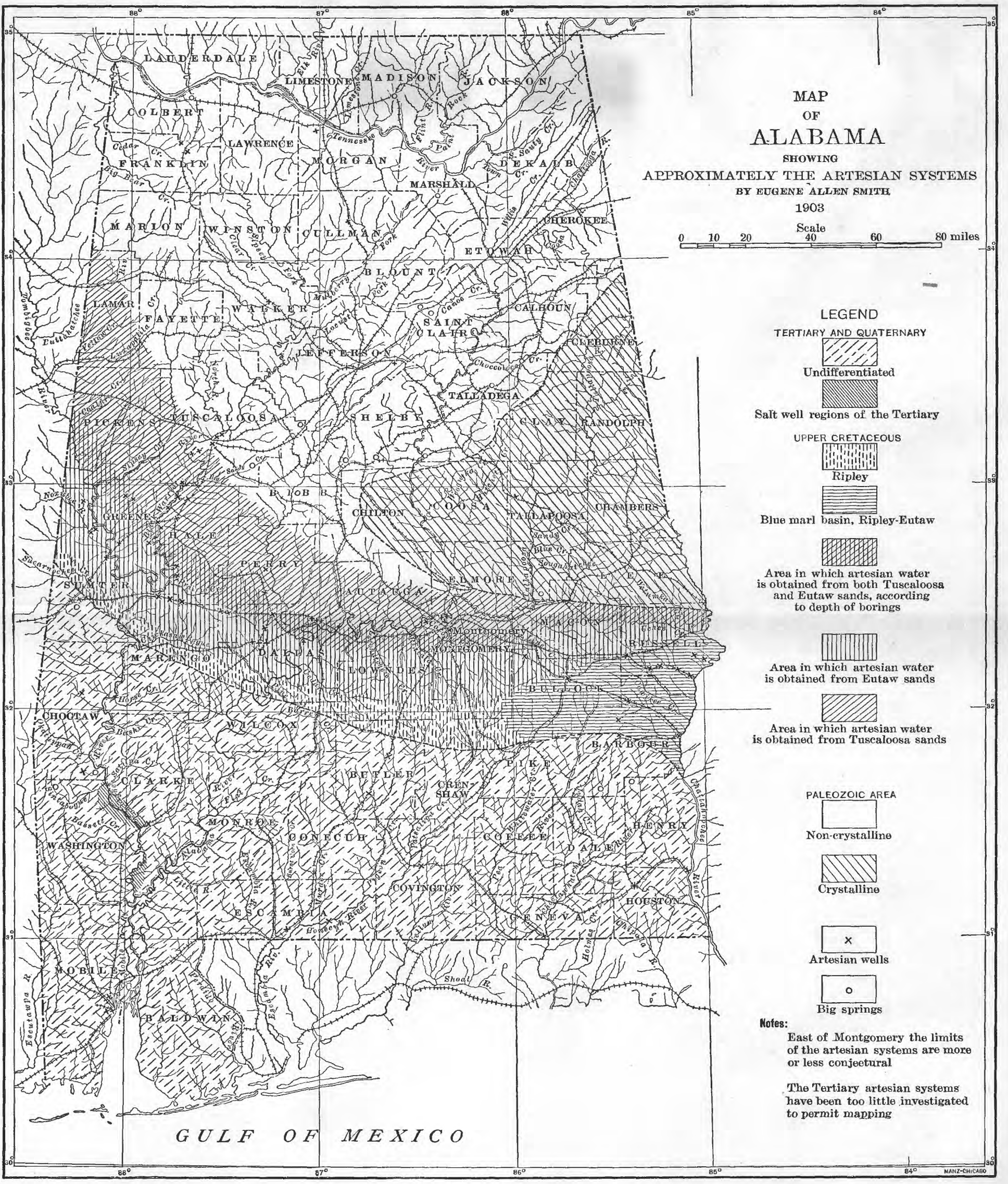


Hatchetigbee. The same conditions prevail, also, in the lower part of the Claiborne division, but the St. Stephens limestone at the top of the Eocene is, of course, not to be counted among the good water bearers. In the Tertiary area of Alabama the artesian wells are not so common as in Mississippi, but there are enough of them to prove that artesian water of good quality may be had in abundance. The abundance of good water furnished by the Lafayette formation has rendered the sinking of artesian wells for individual use unnecessary, but many towns in the lower counties have recourse to deep borings for their supplies, and the number of artesian wells increases yearly.

The late Tertiary (Miocene) formations underlying Mobile and Baldwin counties, have likewise all the requisites of artesian systems. In and near the city of Mobile several wells, 700 to 1,550 feet deep, obtain abundant water, which is sometimes potable and sometimes excessively salty. On the coast at Bayou La Batre an artesian well supplies the canning factory. It is 580 feet deep, and the water rises 15 feet above the surface. The water holds only 14.4 grains of dissolved mineral salts per gallon, chiefly the chloride and carbonate of sodium.

\section{BRINE AND GAS WELLS.}

This record would be incomplete without some reference to the brine and gas wells of Washington and Clarke counties, which occur along the southern border of the Hatchetigbee anticline and its southeastward prolongation. Most of these borings are located in the palmetto flats of small creeks, near their mouths, and at the base of hills capped with the St. Stephens limestone. Beginning in Claiborne strata at the surface they penetrate 100 to 400 feet into the underlying Hatchetigbee sands. The water rises to the surface in all cases, and at many points there are natural brine oozes, which may be converted into reservoirs of salt water by inclosing an area of 15 or 20 feet diameter by a palisade of heavy timbers and digging out the interior. During the civil war the brine from these wells and reservoirs was extensively used in the manufacture of salt. In most cases natural gas in considerable quantity accompanies the salt water, and frequently the weak brines are strongly impregnated with sulphuretted hydrogen gas, producing the most palatable sulphur waters in the State.

Of this character are the waters of the well at Jackson, in Clarke County, and at several of the salt works. Natural gas is also associated with the salt waters from other horizons. The deep well at Cullom Springs, Choctaw County, yields much gas along with salt water, and the Bascomb well near Mobile throws up a foaming jet of mingled salt and gas, which on ignition burns with a flame several feet in height. 


\section{MINERAL SPRINGS.}

Of the many large springs only eight were reported in 1902 as utilizing their water for shipment. These springs are as follows:

Bailey Springs, Bailey Springs, Lauderdale County.

Cherokee Spring, Citronelle, Mobile County.

Healing Springs, Healing Springs, Washington County.

Ingram Lithia Springs, Calhoun County.

MacGregor Spring, Spring Hill, Mobile County.

Tallaciega Springs, Talladega County.

Wilkinson's Matchless Mineral Wells, Greenville, Butler County.

York Aperient Well, York, Sumter County.

The total output is placed at 68,050 gallons, with a value of $\$ 28,109$.

\section{PRINCIPAI PUBLICATIONS.}

Mineral springs of the United States, by A. C. Peale: Bull. U. S. Geol. Survey No. 32 , pp. 88-94.

Preliminary list of deep borings in the United States, pt. 1, by N. H. Darton: WaterSupply and Irrig. Paper U. S. Geol. Survey No. 57, pp. 10-11.

Alabama [well records], by E. A. Smith: Water-Supply and Irrig. Paper U. S. Geol. Survey No. 102, pp. 276-331. 


\section{MISSISSIPPI.}

By L. C. Johnson.

\section{GEOLOGY.}

The geologic structure of Mississippi is very simple, but the details of the distribution of various formations are hard to make out owing to the extent to which the underlying rocks are concealed by more recent deposits, such as the river alluvium, loess, and Orange sand or Lafayette formation.

The oldest rocks in the State are comprised in a series of limestones of Mississippian ("Lower Carboniferous") age, which outcrop in northeastern Mississippi and cover much of Tishomingo County, and a small portion of Itawamba County. South, southwest, and west of this older rock mass outcrop successive parallel bands of later rocks, which dip away from the Carboniferous mass in a direction which varies from south to west. Along the Alabama State line, for example, the dip is practically due south; along the Tennessee line it is almost due west, while in intervening sections it is southwest. The amount is slight, averaging probably about 25 to 35 feet to the mile. Southward or westward from Tishomingo County newer and newer series of rocks outcrop until recent alluvial deposits are found along the Gulf and Mississippi River.

The distribution of the more important of the geologic formations are shown in the accompanying sketch map (fig. 23).

\section{MISSISSIPPIAN ("LOWER CARBONIFEROUS") ROCKS.}

The Mississippian rocks occupy an area covering portions of Tishomingo and Itawamba counties. They consist largely of limestones. They abound in springs, which are so numerous and accessible that there has been little demand for deep borings, though open wells with a depth of 100 feet and yielding good water are not uncommon. A few of the well waters are mineralized. Some of the springs issue from the Mississippian rocks and some from the Cretaceous sands which thinly cover the harder rocks along the borders of the area.

Two important springs oceur in the area. The first, known as Bay Spring, is located near the falls of Mackay Creek, and may have its source within fissures of the limestone. The waters are of normal purity. The second spring, the Iuka, is a medicinal spring containing

IRR $114-05-12$ 
considerable amounts of sulphur, iron, sodium, and calcium. It is located in the city of the same name and has been developed as a health and pleasure resort.

\section{CRETACEOUS DEPOSITS.}

Southwest of the Mississippian area are the Cretaceous formations. .These occupy a belt outcropping around the area of Mississippian rocks. In general, water may we obtained in this section by wells at

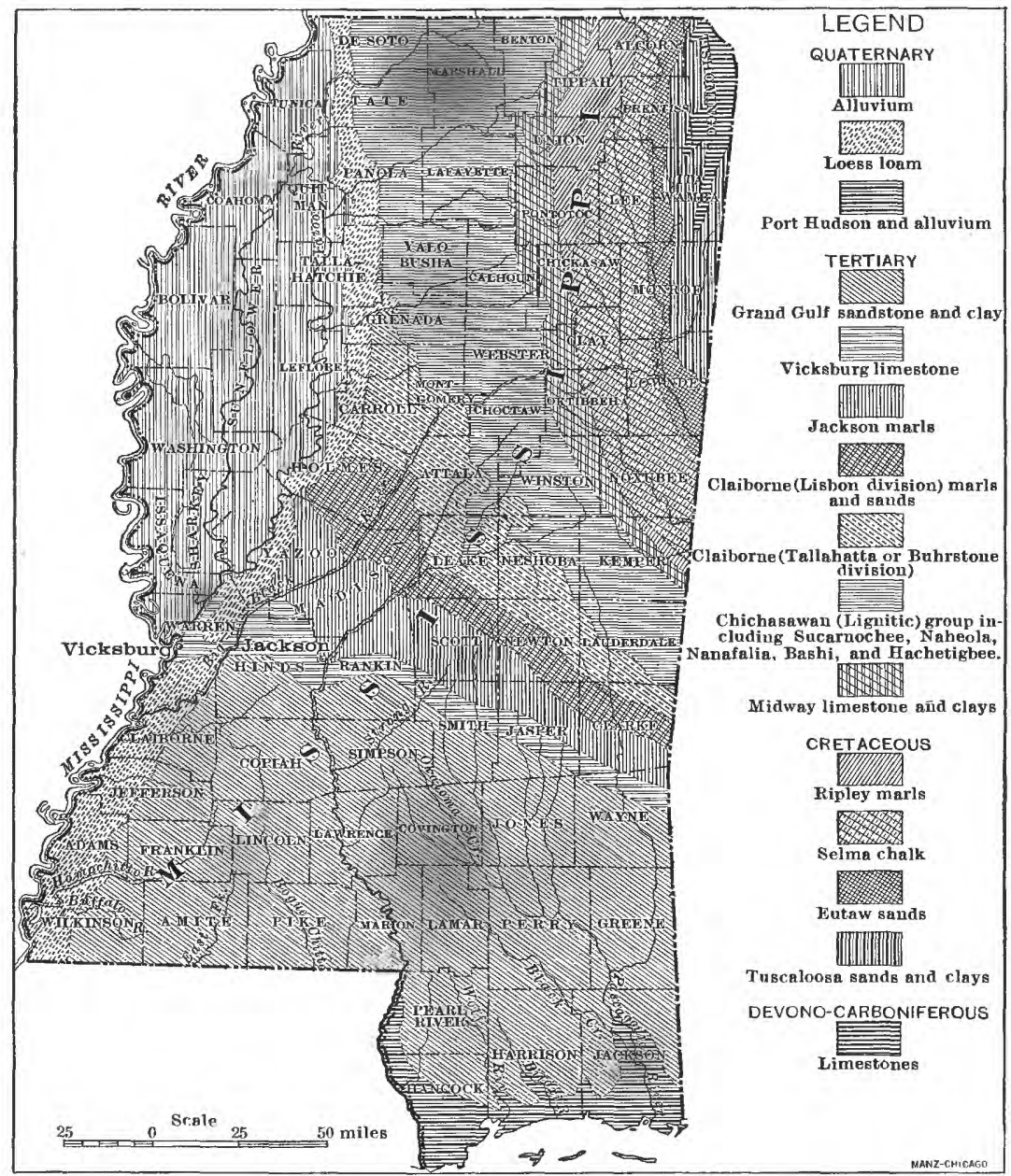

Fig. 23.-Geologic sketch map of Mississippi.

a depth of from 200 to 1,500 feet, the depth increasing with the distance from the contact with the Mississippian. Few of the wells flow, but the water generally rises to within easy pumping distance of the surface. In quality, the water is usually more or less alkaline, but in a few wells it is pure and soft. 
Tuscaloosa for nation. - This oldest Cretaceous formation, which consists largely of variable beds of sands and clays, is separated into two parts by a persistent bed of purplish clay. The upper portion generally yields only small amounts of unsatisfactory water, but the lower half and the sandy bed at the top of the upper half yield copious supplies of good water. Wells drawing their supplies from this formation are located at Columbus, Lowndes County, at Gattman, Aberdeen, and Amory, Monroe County, and elsewhere. Springs are not uncornmon where streams have cut into the deposits. Kolola Spring on Buttahatchee River, in Lowndes County, has considerable reputation because of the medicinal properties of its water, which carries sodium, potassium, magnesium, calcium, and iron, especially the latter.

Eutaw beds.-The name Eutaw has been applied to the sandy beds between the Tuscaloosa formation and the overlying Selma chalk. In Alabama the Eutaw beds usually yield saline waters, but in Mississippi they are not water bearing, the wells generally passing through them into the underlying Tuscaloosa formation.

Selma chalk or Rotten limestone.--In Mississippi this formation is not a water-bearer, but throughout the prairie regions of the northeastern part of the State it serves as a cap rock to the water-bearing bed at the top of the Tuscaloosa formation. There are more than a hundred deep wells each in Noxubee, Lowndes, Clay, Monroe, and Lee counties, and there is a large number of wells in Oktibbeha, Chickasaw, Prentiss, and Union counties. In the western parts of these counties there are fewer wells than in the eastern, not because of the impossibility of obtaining water, but because the wells must be deeper and are therefore more costly.

The regularity of the water-bearing beds as shown by the wells indicates there has been no material disturbance or dislocation of the deposits beyond a simple tilting westward from the contact of the Rotten limestone and Tuscaloosa beds at the rate of 25 feet to the mile.

Ripley beds. - The Ripley beds in Mississippi consist of a series of sands, marls, and limestones outcropping west and southwest of the Selma chalk or Rotten limestone. Until recently no water supplies of importance had been obtained from these beds, but abundant water has lately been found in a number of wells at Ecru, in Pontotoc County. The wells appear to be located in a local syncline or trough and have an average depth of about 200 feet. Most of them flow at the surface.

Springs are not abundant in the Ripley beds, but they frequently occur along its contact with the overlying Lafayette sands and gravel. The large Blue Mountain Spring is an example of this type. It carries a small amount of calcium and magnesium carbonates, derived, it is supposed, from the underlying marls of the Ripley beds. 


\section{TERTIARY DEPOSITS.}

Westward from the limits of the Selma chalk or Rotten limestone to the delta district, and southward to the southern portion of the State, lies the broad belt of Tertiary deposits, which have been divided into a considerable number of formations, each of which is considered below.

Midway.-The Midway beds consist of limestones overlying the Ripley sands, marls, etc. The thickness is slight and they do not carry any considerable amount of water.

"Lignitic" group.-One of the most important divisions of the Tertiary is the "Lignitic" group, which is further subdivided in Alabama into (1) the Sucarnochee, consisting of black clays, (2) the Naheola, (3) the Nanafalia, (4) the Bashi, and (5) the Hatchetigbee formations. The last four consist largely of gray lignitic clays, with occasional marl beds and some water-bearing sand.

The general structure of the region underlain by the Lignitic group is favorable to obtaining water, both by wells and springs. The surface elevation, however, is so nearly uniform that even deep borings seldom produce flowing wells. Where the streams have cut into the deposits numerous springs issue from the banks, except in the case of the Sucarnochee formation.

The Sucarnochee formation is a deep black clay, very impervious to water. Springs frequently issue from the more porous beds overlying it, but it is itself practically destitute of water.

The Naheola formation contains a few sandy beds yielding small flows of water. Wells at Lauderdale penetrate these beds at depths of from 100 to 200 feet, and obtain weak flows rising 2 or 3 feet above the surface. Similar wells have been obtained in this formation at scattering points elsewhere. Some of the largest springs of Mississippi appear at the contact of the Naheola with the underlying clays of the Sucarnochee formation. Like the Naheola these formations consist of grayish lignitic clays with occasional marl and sand beds. They are not important water horizons. At Meridian borings penetrated the "Lignitic" strata from the Hatchetigbee down to the Sucarnochee, but the water only rose to within 20 feet of the surface.

There are a number of springs from the Nanafalia formation, one of

- which, the Lauderdale, is of considerable importance. The waters, which carry considerable sulphur, issue from lignitic beds on a branch of the Sucarnochee River, near Lauderdale. A health resort has been developed at the spring.

The Hatchetigbee formation is similar to the preceding Lignitic formations, but carries thicker beds of sand, and is therefore a more important water-bearing formation. It underlies a considerable portion of the delta deposits, and is thought to be the source of water of 
the wells drilled through the deposits of the delta at Memphis, Tenn., Tunica, Coahoma, Quitman, Tallahatchie, Leflore, Sunflower, Bolivar, and other places. The depth constantly increases toward the south and west from 850 to 1,300 feet.

The most important spring in the Hatchetigbee deposits is the Arundel Lithia Spring. The water issues from the Hatchetigbee sands, where Oktibbee River and Sowoshee Creek have removed the Buhrstone and cut away the sands down to the stiff clay beneath. Considerable amounts of the water are sold. The whole of the adjoining region is marked by numerous springs, but in general none of them have been improved nor the water marketed.

Tallahatta formation (buhrstone). - The Tallahatta formation consists essentially of a series of hard sandy beds, more or less porous in places, comprising the lower portion of the Claiborne group. It contains little water in itself, but forms an impervious cap rock to the water-bearing sands of the underlying Hatchetigbee. By its resistance to erosion the Tallahatta has given rise to an elevated ridge which is of much assistance in the location of water-bearing beds. Water which rises to a greater or less distance is almost always found beneath it, the local topography determining whether the well will flow or not. This horizon supplies the wells at Stonewall (300 feet), Quitman (500 feet), Enterprise (200 feet), all in Clarke County; at Grahams Switch (90 feet), and Meehan Junction, in Lauderdale County, and at Chunky and Hickory (500 feet), in Newton County. It is also probable that the artesian flows at West, Pickens, Durant, Tchula, and Lexington, in Holmes County, are from the same source. To the above list may possibly be added the deep wells at Jackson, Hinds County (964 feet), and at Canton, Madison County (1,020 feet), both of which, however, were bored through the Jackson and Claiborne marls before penetrating the Hatchetigbee beneath the buhrstone.

Lisbon formation (calcareous Claiborne).-This formation consists of marls and green sand, and has a total thickness of about 300 feet. It contains several minor beds of ferruginous water-bearing sands, but none of them are as persistent as the Hatchetigbee. One of these beds is encountered at 300 feet at Shubuta, and at 500 feet at Waynesboro. The water from these wells is colored by the iron, and is also highly alkaline.

A local sand bed of the Lisbon formation yields colorless, but chalybeate water in the double wells at Shubuta, and in the wells at De Soto and Pachuta. The water in the last well only comes within 20 feet of the surface.

Springs are by no means tare in the Lisbon area, but they are generally supposed to come from the overlying Lafayette sand. A few, however, are probably of deeper-seated origin. The Archusa Spring, near Quitman, Clarke County, is derived from these beds. 
The water is sulphurous and alkaline. The Pierce Spring, near the banks of Bucatanna Creek, in eastern Clarke County, is also strongly mineralized. The Robinson Spring, in Madison County, which has been developed as a health resort, yields water similar to that of the springs in Clarke County.

Jackson and Vicksburg formations.-These two formations, which may be grouped together, consist of marls, clays, and limestone, the latter predominating in the upper or Vicksburg division. There are few sandy beds and artesian waters are generally lacking. The flowing wells located in the area of outcrop obtain water from the ferruginous sands of the Lisbon formation at Shubuta and Waynesboro, and from the Hatchetigbee sands at Jackson (964 feet) and Canton (1,020 feet). An important mineral well, known as the Cooper well, is located 3 miles east of Raymond. It is 90 feet deep, and at this point has been developed the most important health resort in the State. The water contains iron, magnesia, soda, and sulphur. Another wellknown mineral well, near Hazlehurst, Copiah County, obtains water from this formation. The water is impregnated with sodium and magnesium chlorides and calcium sulphates. It occurs at a depth of 63 feet, probably in a lignite bed. A third mineral well of importance is the Godbold, $1 \frac{1}{4}$ miles from Summit, Pike County.

Springs in the area of outcrop of this formation are really from the sands and gravels of the overlying Lafayette. The best known of these break out along Paulding Ridge, in Jasper County. Those issuing on the north side generally yield pure, soft water; those on the south are usually mineralized. The Phalti Spring (sec. 8,2 N., R. 13 E.); Bay Spring, at Bayspring post-office; Donald's mineral spring, near Weems; and Vosburg and Stafford springs, in the same vicinity, are among the most important.

Grand Gulf group.-The Grand Gulf is by far the most extensive formation in the State, and consists of a variable series of sandstones, sands, and lignitic clays. Practically every sand bed, of which there are a great number, is water bearing, and supplies are obtained by dug, bored, and drilled wells. Where stream erosion has cut into the beds to any considerable distance springs occur. At Hattiesburg, Laurel, Brookhaven, and Natchez water is obtained at depths of from 200 to 400 feet, but only at Hattiesburg does it rise above the surface. There are considerable evidences of undulations of the beds in the Grand Gulf area, the flowing water at Hattiesburg being referred to a shallow synclinal trough at that point.

Among the springs and mineral wells may be mentioned the Mississippi Springs in Hinds County (sec. 2, T. 5 N., R. 4 E.); the Mammoth Mineral Springs, Perry County (secs. 24 and 25, T. 5 N., R. 14 W.); and Rawls Spring, 2 miles farther west. The Mammoth Spring, 6 miles northwest of Hattiesburg, is a large spring issuing from lig- 
nitic clays. Both the Mammoth and Rawls springs are noted for the medicinal value of their waters.

\section{QUATERNARY.}

Lafayette sands and gravels. - The Lafayette formation is poorly defined, but may be considered as made up of a series of yellowish or orange sands and gravels occurring as a mantle over the outeropping edges of the Grand Gulf and other formations. Because of its sandy and gravelly character it contains, especially at the base, a large amount of water, which is usually pure and soft, and which is obtained by shallow wells.

Loess and loam.-The loess consists of fine fossiliferous yellowish silts, while the loam consists of browner silts, possibly produced by the weathering of the loess. The deposits occur over the Yazoo delta region in the northwestern part of the State. Only very small amounts of water can be obtained in the loess or loam, practically all of the wells passing through it into the underlying Lafayette or still older formations.

Pontchartrain clay and Biloxi sand.--The Pontehartrain clay is a greenish clay occurring in a narrow belt in the extreme southern part of the State, and separated from the coast by a very narrow strip of sandy beds, known as Biloxi sands. Shallow wells in these two formations every where obtain abundant water at shallow depths, although the quality is not always satisfactory. To obtain flowing water the wells must extend to the Grand Gulf formation. Water is found at depths of approximately $400,600,700,850$, and 900 feet.

The buckshot lands of the delta have sometimes been referred to the Port Hudson group, which includes the two formations under discussion. The water is generally fairly abundant and soft, but has not been found to be wholesome for drinking. In the northern part of the delta area water can be obtained from deep wells reaching to the Tertiary beds:

Alluvium.-Under alluvium are included the surface materials of the Mississippi delta region and the deposits in the lower portions of the courses of other large streams. The waters, though soft, are not regarded as wholesome.

\section{MINERAL WATERS.}

In 1902 shipments of mineral water were reported from the following seven springs:

Arundel Lithia Springs, near Meridian, Lauderdale County.

Browns Wells, Browns Wells, Copiah County.

Castalian Springs, near Durant, Holmes County.

Godbold Mineral Well, near Summit, Pike County.

Lowes Wells, Hazlehurst, Copiah County.

Robinson Mineral Springs, Robinson Springs, Madison County.

Stafford Mineral Springs, near Vosburg, Jasper County. 
UNDERGROUND WATERS, EASTERN UNITED STATES. [NO. 114.

The aggregate amount sold is reported as 459,485 gallons, valued at $\$ 77,868$.

\section{PRINCIPAL PUBLICATIONS.}

Mineral springs of the United States, by A. C. Peale: Bull. U. S. Geol. Survey No. 32, pp. 95-97.

Preliminary list of deep borings in the United States, pt. 1, by N. H. Darton: Water-Supply and Irrig. Paper U. S. Geol. Survey No. 57, pp. 57.

Mississippi [well records], by L. C. Johnson and E. C. Eckel: Water-Supply and Irrig. Paper U. S. Geol. Survey No. 102, pp. 332-357. 


\section{LOUISIANA AND SOUTHERN ARKANSAS. ${ }^{a}$}

By A. C. Veatch.

\section{GENERAL GEOLOGY.}

Louisiana and Arkansas, south of Arkansas River and the mountains, have the same general structure as the great American Coastal Plain, of which they form a part. The land is highest toward the old plateau and mountain region to the northwest. The beds are for the most part unconsolidated, succeed one another in more or less regular succession, range in age from Cretaceous to Recent, and in general have a dip coastward that is greater than the slope of the surface. This relation of dip to surface slope supplies conditions which are favorable for artesian water, therefore flowing wells should be expected in many parts of the Coastal Plain. In some cases the leakage and resistance of the sands so reduces the pressure that the water will not flow, although the altitude of the well mouth is less than that of the point where the sands come to the surface and where the water enters; in others, erosion has so changed the surface of the plain that the well mouth, though south of the outcrop of the water-bearing bed, is higher, and the water, therefore, will not flow. In Louisiana and southern Arkansas the older beds slope toward the Mississippi Valley as well as toward the coast. Some of these older beds are very much disturbed and form peculiar, sharp domes, and as they often contain salt water, and are frequently broken by the folding, the salt water is free to pass into the sands of the surrounding younger formations. While these domes disturb the conditions in certain tracts, there are still larger areas in which wells have found good water. A study of these well records and of the general structure of the country shows that the following principal water horizons are present: Bingen sand, Nacatoch sand, Sabine sands, Catahoula sandstone, Pliocene and Quaternary sands and gravels.

The relation of these beds to one another is shown in tigs. 24 and 25 , and their geologic age and relation to adjacent beds are shown in the table following.

\footnotetext{
a A preliminary statement. A detailed report on this area, embodying records of all important wells and well prospects for each county is low in preparation and will be ready for distribution late in 1905 .
} 
Water-bearing value of geologic formations of Louisiana and southern Arkansas.

\begin{tabular}{|c|c|c|}
\hline Period or formation. & $\begin{array}{l}\text { Maximum } \\
\text { thickness. }\end{array}$ & Water-bearing value. \\
\hline Quaternary .. & & $\begin{array}{l}\text { Contains gravel and sand beds, which furnish } \\
\text { the main supply of water in southern Louis- } \\
\text { iana. }\end{array}$ \\
\hline Pliocene. & 2,000 & $\begin{array}{l}\text { As surficial deposits on the uplands and in the } \\
\text { valleys, supply much of the shallow well } \\
\text { water of this region. }\end{array}$ \\
\hline Miocene...... & $(?)$ & $\begin{array}{l}\text { No surface outcrop, and hence probably of no } \\
\text { importance as a water horizon. }\end{array}$ \\
\hline Oligocene: & & \\
\hline Fleming . & \pm 200 & Clays and marly clays; no water-bearing value. \\
\hline Catahoula. & $b 1,000$ & $\begin{array}{l}\text { The coarser sandstone layers of this formation } \\
\text { furnish excellent water. Three or four hori- } \\
\text { zons have been developed. }\end{array}$ \\
\hline Vicksburg - & $50-100$ & $\begin{array}{l}\text { Exposed in only one part of the area and of } \\
\text { no importance from a water standpoint. }\end{array}$ \\
\hline Eocene: & & \\
\hline Jackson & 500 & $\begin{array}{l}\text { Clays and clay marls with occasional sand beds; } \\
\text { water generally hard and seldom developed. }\end{array}$ \\
\hline Cockfield & 500 & $\begin{array}{l}\text { The sandy beds occurring near the base of } \\
\text { the formation are second in importance only } \\
\text { to the Sabine. }\end{array}$ \\
\hline Claiborne. & 500 & $\begin{array}{l}\text { Clays and clay marls containing sand beds of } \\
\text { little importance as water horizons. }\end{array}$ \\
\hline Sabine $e$ & 1,000 & $\begin{array}{l}\text { The sands of this formation are the important } \\
\text { water horizons of the greater part of northern } \\
\text { Louisiana and adjacent parts of Arkansas. }\end{array}$ \\
\hline Midw & $(?)$ & $\begin{array}{l}\text { Exposed only to a limited extent in one part of } \\
\text { the area, and unimportant as a water-bearer. }\end{array}$ \\
\hline per Creta & & \\
\hline & $d 600$ & $\begin{array}{l}\text { Clay beds, which serve to retain water in } \\
\text { Washington sands. }\end{array}$ \\
\hline Nacatoch & $150-200$ & $\begin{array}{l}\text { One of the most extensively developed water } \\
\text { sands of this region. Very good water } \\
\text { near the outcrop, but brackish in the embed. }\end{array}$ \\
\hline Marlbroc & 400 & Clays, clay marls, and chalk; serve to retain \\
\hline Annona & +100 & water in the Bingen sands \\
\hline Brownstown . & 300 & \\
\hline Bingen & +500 & $\begin{array}{l}\text { Persistent sandy bed, furnishing water over } \\
\text { a wide area. }\end{array}$ \\
\hline Lower Cretaceous & $e 550$ & $\begin{array}{l}\text { Not known to contain any important water- } \\
\text { bearing layers in this region, though the } \\
\text { great development in eastern Texas would } \\
\text { lead us to expect some development here. }\end{array}$ \\
\hline Paleozoic.. & (?) & $\begin{array}{l}\text { Hard rock layer very much disturbed. Con- } \\
\text { tains water, but its occurrence can not be } \\
\text { predicted until the geology of the region is } \\
\text { minutely understood. In general, not very } \\
\text { good field for water wells. }\end{array}$ \\
\hline
\end{tabular}

$a$ Harris, G. D., Organic remains from the deep well at Galveston· Fourth Ann. Rept. Geol. Survey Texas, 1893, p. 118. Harris, G. D., Report of Louisiana Geol. Survey for 1902, p. 32.

$b$ Based on dip calculations on the Sabine River, and on the thickness of these beds in the Alexandria, La., wells, $800+$ feet.

$c$ Name adopted to supplant Lignitic: taken from typical fosiliferous development of the formation on the Sabine River, in Sabine County, Tex., and Sabine Parish, La.

$d$ Based on wells south of Hope, at Arkadelphia and Shreveport; may be in part Midway.

$e$ Hill, R. T., The Mesozoic geology of southern Arkansas: Ann. Rept. Arkansas Geol. Survey for 1888, p. 188. 


\section{WATER HORIZONS.}

Lower Cretaceons. - The lower Cretaceous occupies the wedge-shapea territory between the Paleozoic rocks and the Bingen sands (fig. 24). All deep wells in this region have thus far failed to yield water, though the extensive development of water sands in this group in Texas leads

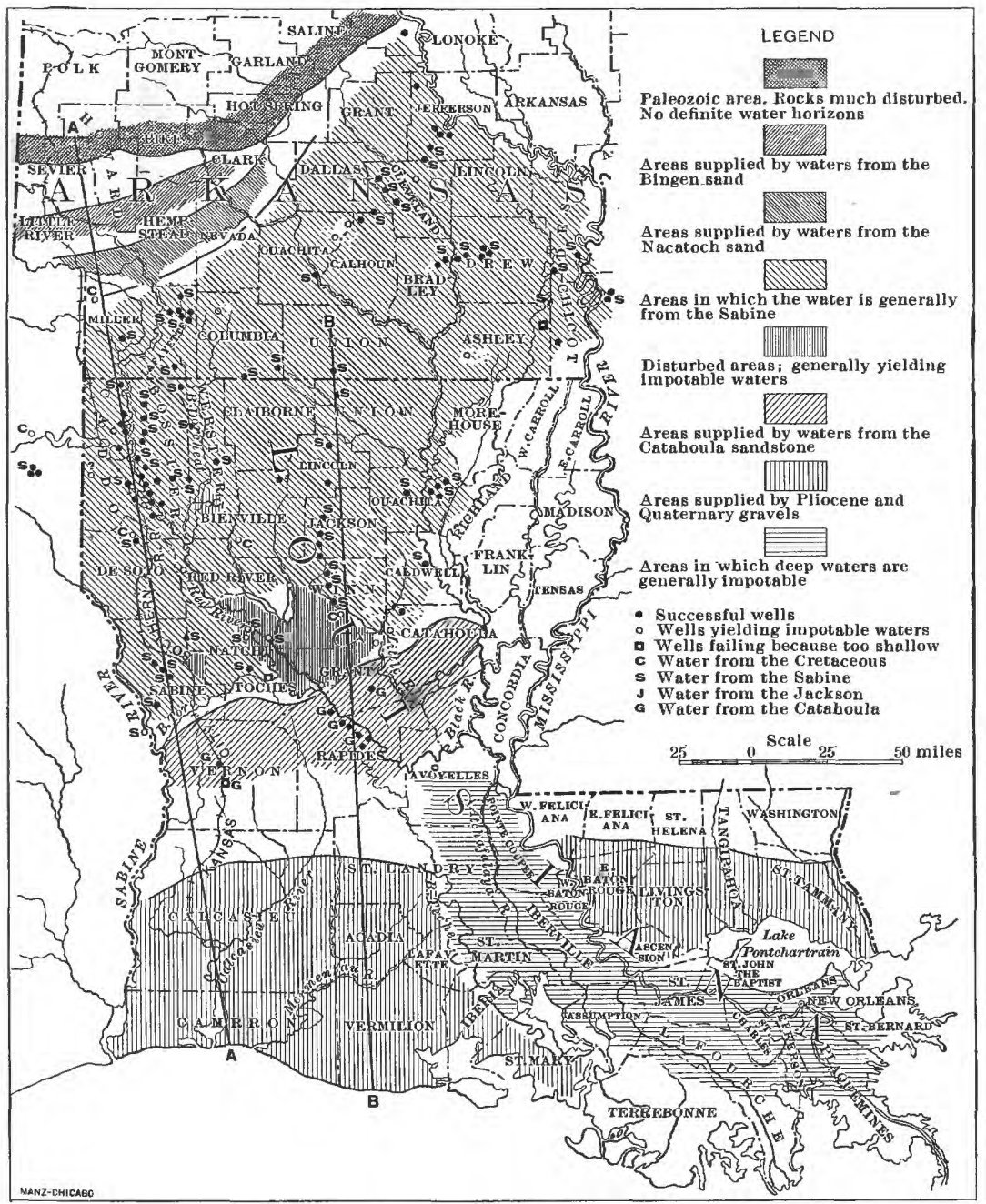

FIG. 24.-Deep-water prospects in Louisiana and southern Arkansas. A-A, line of section shown in fig. $26 ; \mathrm{B}-\mathrm{B}$, line of section shown in fig. 27.

to the belief that further attempts, especially in the western part of the State, will not be fruitless. The best water-bearing sands are to be expected near the base of the Cretaceous or just above bed rock. The depths at which bed rock will be encountered may be roughly found by multiplying the distance in miles between the Paleozoic out- 
crop and the point where the well is to be sunk by the average rate of slope of the bed-rock surface, 100 to 125 feet per mile.

Bingen sand. ${ }^{a}$ - The Bingen sand comes to the surface along and south of the line shown in figs. 24 and 25. Along this line shallow wells are, therefore, the rule, but as the sand dips at a rate of 50 to 75 feet per

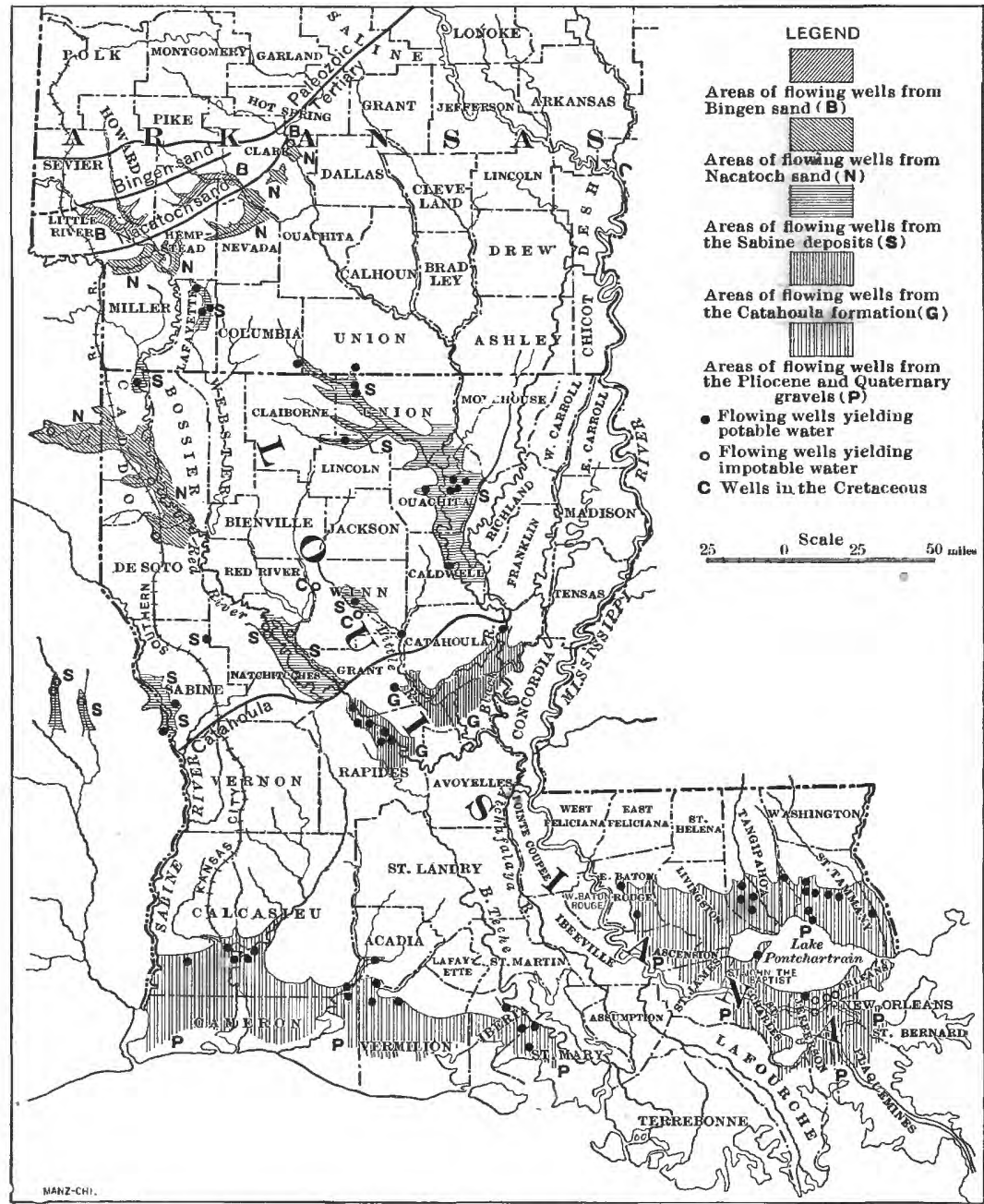

FIG. 25.-Artesian areus in Louisiana and southern Arkansas.

mile in a southeasterly direction, the wells get deeper to the south, and reach an extreme depth of 784 feet near Columbus, a little north of the outcrop of the Nacatoch sand. Some failures have been reported in the lower part of this territory, notably at Columbus and

a Name used by Hill for beds which he doubtfully referred to the Eocene. These, with the exception of a single Nacatoch outcrop which was incorrectly included in this series, are now known to pass beneath the Brownstown and to represent the littoral beds of the basal upper Cretaceous. 
Washington, but they were due to the fact that the wells were abandoned before the required depth had been reached. The greatest development has naturally been in the region where flowing water can be obtained (fig. 25). The maximum depth to which wells will be driven in this region will probably not exceed 900 feet, as before this depth will become necessary the Nacatoch sands will appear on the surface, making good shallow wells possible.

The water is very soft and somewhat alkaline, except in wells which do not flow and have only been partially cased, and in which the water therefore stands in contact with the overlying calcareous clays. Hard water has been found in a few wells, as at Hudson and near Burtsell, but in these it seems to occur in the calcareous beds which overlie the Bingen sands, and the indications are that if the wells had been deepened 200 or 300 feet they would have reached the Bingen and obtained soft water.

Nacatoch sand ${ }^{a}$.-This sand, like the Bingen, is of very great value to a large section in southern Arkansas, where it is practically the only available source of well water. In areas underlain by the Bingen and Nacatoch sands the surface formations are rich, calcareous clays, with here and there thin coatings of younger gravel, and the surface water is generally hard and very unsatisfactory. Persistent water-bearing horizons, which are so well understood that the depth to water can be predicted at any point and which will furnish soft artesian water over wide areas, can not fail to have a great effect on the development and land values of the regions which they underlie.

The Nacatoch sand has been extensively developed along the line of the Iron Mountain Railroad from west of Red River almost to Arkadelphia (fig. 24). It dips southeastward at a rate of from 50 to 100 feet per mile until it reaches a point about 800 feet below sea level, when it abruptly becomes horizontal and continues so to

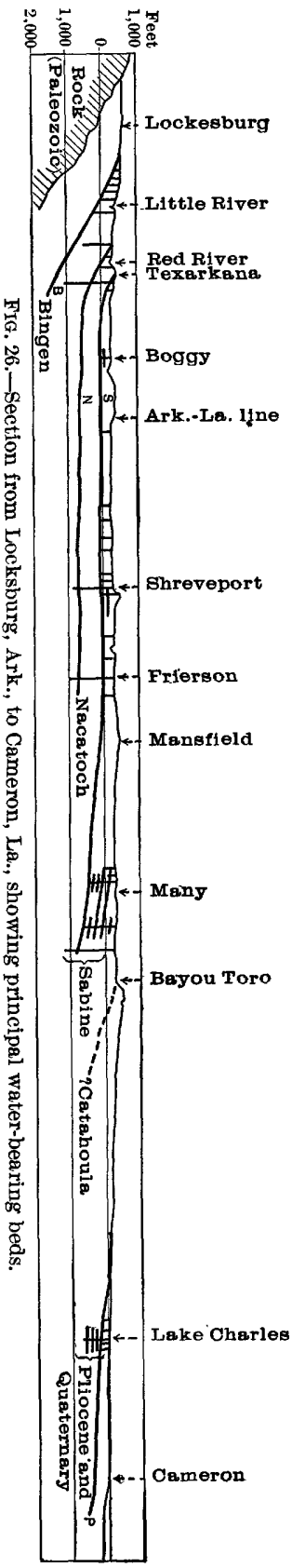
a point somewhat south of Shreveport, where it again slopes normally

a Name taken from typical exprsure at Nacatoch Bluff on Little Missouri River in Clark County. This formation includes the sand beds between the Marlbrook and Arkadelphia which Hill included in his Washington or High Bluff greensands (Ann. Rept. Arkansas Geol. Survey for 1888, vol. 2, 1888, pp. 72-75, 188). 
coastward (fig. 26). This extensive horizontal development would make this sand of great value over wide areas were it not for the fact that south of a line which runs irregularly from 3 to 15 miles from the outerop the water is salty. Seemingly that portion of the sand near the outcrop has been thoroughly washed by percolating waters, while that less favorably situ. ated is in its original salty condition, and the saltiness may even have been increased by matter washed down from the upper layers. Developments at Texarkana, Jefferson, Shreveport, and Frierson have yielded impotable water, which at the last three places is artesian, indicating an artesian basin covering a considerable part of the Red River Valley (fig. 25). The brine which occurs in some of the Cretaceous uplifts in northern Louisiana is likewise from this horizon. In general, it is felt that that portion of the sand whicb lies south of the area shown in fig. 24 will not furnish potable water.

Sabine group.--Under this head is classed not a single well-defined horizon like the Nacatoch, or Bingen, or other Cretaceous beds, but a number of somewhat irregular water sands occurring throughout a formation which, in the western part of this area attains a tbickness of perhaps 1,000 feet. The lowest of these sands occurs about 700 feet above the Nacatoch, and like it, is very nearly horizontal over a considerable area (figs. 26,27). Eastward and southward this bed dips gently toward the Mississippi Valley and the coast.

Other sand beds occur in the formation above this one, at varying distances from each other, and of varying thickness. Nine have been developed at Plymouth, La., and six at Ruston. These beds thin and thicken very rapidly, so that in one

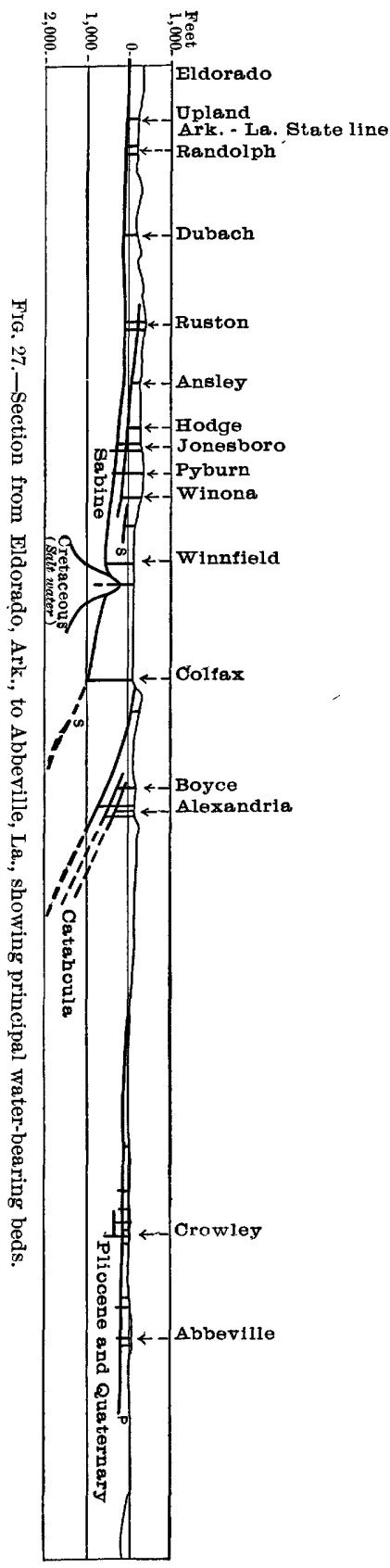
well a sand may be developed which in a nearby well is too thin to give results. Wells, then, show considerable irregularity in depth, 
some wells developing one bed and some another; but in general the wells are deeper to the south and toward the Mississippi Valley, as in each case the dip carries the sands beneath younger beds, and it becomes necessary to pass through a certain thickness of overlying deposits even to reach the topmost water sands of this series.

The failures in the southern part of the territory, near Natchitoches and Luella, La., are due to the occurrence of salt water, which is doubtless traceable, in part, to the neighboring uplifts of the older Cretaceous beds. These beds generally carry artesian brines, and as they are often broken the brine leaks into the surrounding Sabine sands. In the region of these domes it is often possible to predict the position of a sand, but it is quite impossible to indicate the kind of water it will contain. It is believed that the sands which furnish brine at Luella and Natchitoches are a continuation of the sands which yield good water about Shreveport.

Cockfield beds.-Overlying the Sabine are the fossiliferous Claiborne beds, which have little water-bearing value. Above the fossiliferous Claiborne are the Cockfield beds, which contain near their base an important water-bearing borizon. In central Louisiana the deeper wells which penetrate this horizon, as those at Leland, Rochelle, Olla, Tullos, and Colfax, obtain impotable water, though an exception is to be noted in the case of the deep well at Robinsons Ferry on Sabine River, in which a soft, pleasant-tasting water is reported at a depth of 1,010 to 1,030 feet. Near the outcrop successful wells have been finished at Clarks in Catahoula Parish, and at Weavers Spur in Natchitoches Parish.

In southeastern Arkansas and northwestern Mississippi this horizon is very extensively developed and furnishes good supplies of soft alkaline water at depths of 400 to 500 feet below sea level. ${ }^{a}$ Between it and the base of the Jackson in this region a number of water sands have been developed in different wells, but they show little regularity and the better wells have, almost without exception, been finished in the main horizon.

The outerops of the Cockfield sands in Arkansas and Louisiana are all relatively low, and the water will generally not rise much above 100 feet above sea level. Flowing wells will be obtained along the main stream channels in central Louisiana. In Arkansas and northwestern Mississippi the artesian area is near the eastern side of the flood plain where a relatively higher head is developed, because of the greater average height of the Mississippi hill lands. Water will rise very near the surface over all the flood plain, but in Arkansas it is regarded as quite impossible that flowing wells will be obtained.

\footnotetext{
a The wells in Chicot, Drew, Bradley, Cleveland, and Jefferson counties, except the deep ones at Pine Bluff, which are incorrectly marked S in fig. 23 , should be credited to this horizon.
} 
Jackson beds.--Beds of this age generally furnish hard water, and are therefore not extensively developed.

Catahoula beds. ${ }^{a-}$-The sands and sandstone of this formation are good water carriers, and have yielded excellent results in central Louisiana, where they furnish flowing wells at Zimmerman, Boyce, Alexandria, Pollock, and Harrisonburg. Several horizons have boen developed which furnish soft water of a very good quality, and it is probable that over a considerable area along Ouachita and Black rivers and about Cataboula Lake and Little River (fig. 25) flowing water is to be expected from these sands. Flowing wells will doubtless be obtained in Sabine River Valley below the outcrop of the Catahoula, as indicated by the water obtained from these beds on the Angelina near Rockland, Tex.; but in the high hill region about Leesville the wells will probably be very deep, and the water will have to be pumped some distance.

Pliooene and Quaternary gravels.-These sands and gravels underlie a large portion of southern Louisiana, and should doubtless be regarded as the most important water horizon in the State. The outcrops on the hill lands are large, and therefore the amount of rainwater passing into them is great. Covered with the more recent coastal clays, they furnish artesian water over considerable areas (fig. 24), and over still larger areas (fig. 25) the water rises so near the surface that it is readily available for irrigation and other uses. In the Mississippi bottoms, and sometimes toward the coast, the water in these beds is generally so charged with various soluble salts that it is of little value. Under the main river valleys in northern Louisiana and southern Arkansas there are thick deposits of sand and gravel partiaily filling the old valleys. In this, limited supplies can be obtained from driven wells of no great depth, but when large supplies are needed wells should be pushed to the main gravel bed, which overlies the older Cretaceous and Tertiary strata. This can be reached at depths ranging from 75 to 150 feet.

\section{MINERAL SPRINGS.}

Although there are many smatt springs scattered throughout Louisiana, only three reported sales for 1902. These were as follows:

Abita Springs, Abita Springs, St. Tammany Parish.

Mandeville Springs, St. Tammany Parish.

Ozone Springs, Pearl River, St. Tammany Parish.

The total output was 499,261 gallons, with a value of $\$ 43,502 .^{b}$

a Name proposed from typical development of formation in Catahoula Parish, La., used for the lower or typical Grand Gulf of Hilgard as exposed at Grand Gulf, Miss. This formation includes the sandstone-bearing clays between the Vicksburg and Fleming oligocene.

b A. C. Peale, U. S. Geol. Survey, Mineral Waters, 1902. 


\section{PRINCIPAL PUBLICATIONS.}

Mineral springs of the United States, by A. C. Peale: Bull. U. S. Geol. Survey No. 32, pp. 123-124.

Preliminary list of deep borings in the United States, pt. 1, by N. H. Darton: Water-Supply and Irrig. Paper U. S. Geol. Survey No. 57, 1902, pp. 49-50.

Subterranean waters of Louisiana, by G. D. Harris: Louisiana Geol. Survey, Rept. for 1902, pp. 205-252.

Underground waters of southern Louisiana, by G. D. Harris and M. L. Fuller: Water-Supply and Irrig. Paper U. S. Geol. Survey No. 101, 1904.

IRR $114-05-13$ 


\title{
NORTHERN ARKANSAS.
}

\author{
By A. H. Purdue.
}

\section{DESCRIPTION OF THE REGION.}

That part of Arkansas lying north of Arkansas River comprises a little more than half of the area of the State, or about 28,700 square miles. Topographically it is divided into two well-defined areas - the eastern or lowland area and the western or highland area. The average elevation of the lowland area will probably not exceed 225 feet above sea level. The even, monotonous character of the surface is disturbed only by Crowleys Ridge, which extends northward from Mississippi River at Helena to St. Francis River at St. Francis, and into Missouri. This ridge is from 1 to 14 miles wide, and in its highest part is about 400 feet above sea level, or 180 feet above the adjacent lowlands.

The highlands are a part of the Ozark region and vary in altitude from less than 500 to 2,250 feet above sea level. They are divided into two parts, a northern and a southern, each of which is a plateau, much dissected by streams. The southern of these is the higher, and is known as the Boston Mountains. These mountains are highest in the western part of the State and gradually fall eastward, the elevation south of Batesville being 800 feet (aneroid). The Boston Mountains are separated from the lower platean to the north by a more or less bold and irregular escarpment, the height of which varies from 500 to 1,000 feet. Figs. 28 and 29 supplement this description and aid in giving a general idea of the topography of the region.

\section{RESOURCES.}

Resources of the highlands. - The main resources of the highlands are its soil, timber, mineral deposits, and water supplies. While the really rich soil of this part of the State is confined mainly to the narrow flood plains of the valleys, much of the remainder yields fair returns, and practically all of it is well adapted to horticulture. All fruits suited to this latitude flourish. The high altitude, to which the healthful, genial climate is largely attributable, and the universal abundance of pure water have combined to make it a favorable place for settlement 


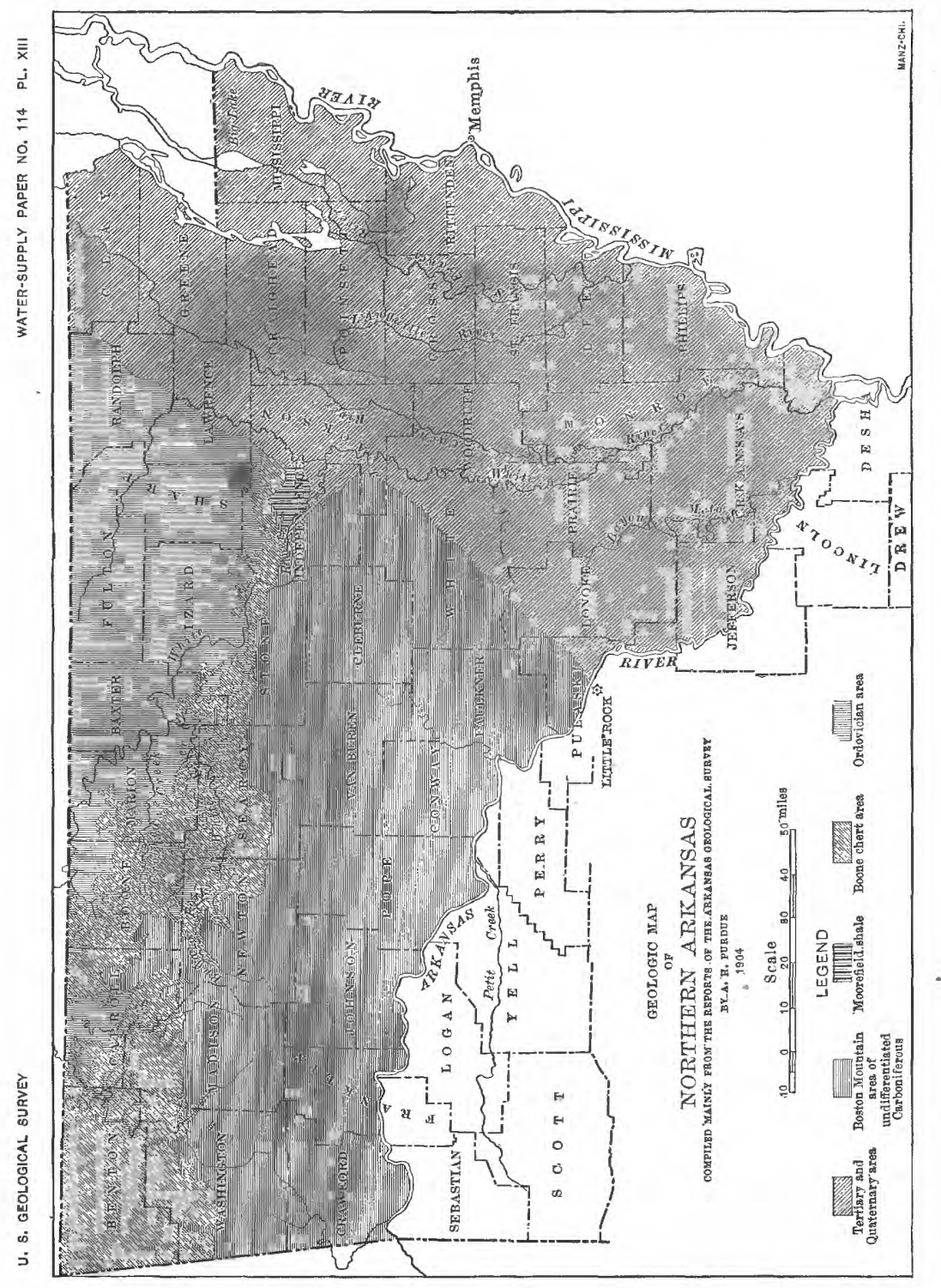


since the early days of exploration. The rough topography has until recently prevented the extensive construction of railroads. At the present time, however, two important lines are being built and are in actual operation over a considerable part of their routes. The region contains large areas of practically undisturbed timber, fine in quality. In the northern part is a large area containing deposits of zinc ores. A thin vein of coal covers a portion of the central part of the region, and along the Arkansas Valley is an abundance of coal, which is being worked at many points. Among other mineral deposits are phosphate, manganese, building stones, and clays in great varieties.

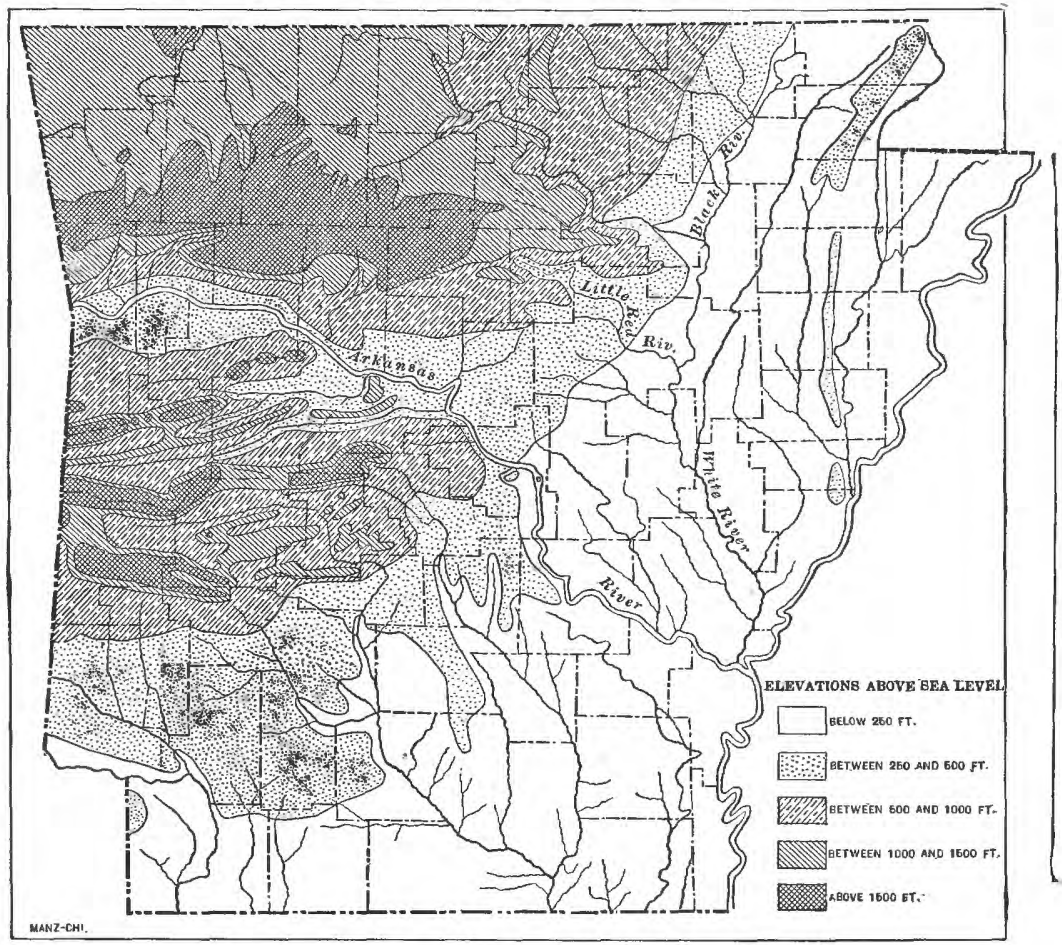

FIG. 28.-Relief map of Arkansas.

Resources of the lowlands. - The wealth of the lowland region is in its soil, timber, and waters. Much of the soil is of unusual fertility. While a great deal of the timber has been removed in recent years, a large amount still remains. As a rule, the population is densest along the river valleys, where the soil is richest, and where transportation was most easily secured in the early settlement of the State. Along Crowleys Ridge the principal towns are Helena, Marianna, Forrest City, Harrisburg, Jonesboro, and Paragould. The narrow strip of land along Arkansas River extending beyond the western border of the State is covered with flood-plain deposits, and should be considered a part of the lowlands. 


\section{GEOLOGY.}

Geology of the plateau region.-The rocks of the plateau region are of Paleozoic age, and include the Ordovician, Silurian, Devonian, and Carboniferous. Ordovician rocks are exposed over a large area in the northeastern part of the division and farther west in Carroll County. They also occur along many of the stream valleys outside these areas. The rocks are of great thickness, and consist mainly of magnesian limestone, though there are a few beds of sandstone and shale.

The Silurian and Devonian rocks are exposed along the steep hillsides bordering the valleys. The Silurian consists of a limestone known as the St. Clair limestone, ${ }^{a}$ and the Devonian of sandstone and shale known, respectively, as the Sylamore sandstone and the Eureka shale.

The Mississippian ("Lower Carboniferous") covers most of the northern division of the plateau area not occupied by the Ordovician, and consists of the Moorefield shale, the Boone chert, the Batesville sandstone, the Fayetteville shale, the Archimedes limestone, and probably some sandstone and shale above the last-named formation. The southern part of the highland area is occupied mainly by rocks of Pennsylvanian ("Upper Carboniferous") age, consisting of some limestone and a heavy deposit of sandstone and shale. The rocks are practically horizontal over the northern division of the plateau region, but from the Boston Mountains southward they fall off by monoclines and faults to the Arkansas River Valley. The structure of the southern part is not sufficiently well known to be shown in the section.

Geology of the lowlands. - With the exception of a sheet of alluvium over a

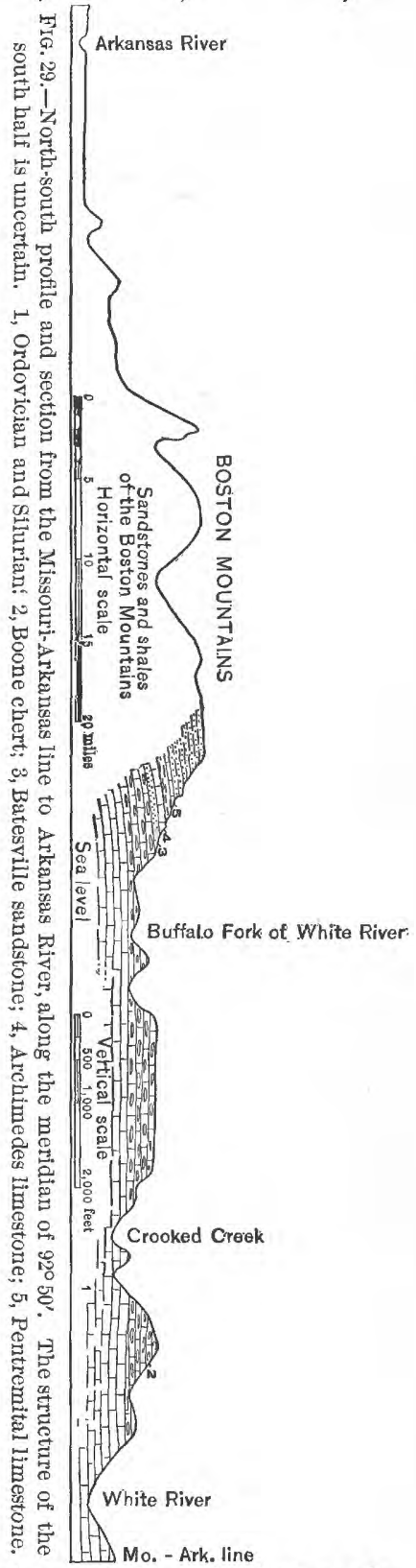
large part of the lowland area the surface rocks of that region are of Tertiary age. They consist almost entirely of unindurated sand

$a$ The geologic nomenclature herein used is that used by the late geological survey of Arkansas. 
and clay, the sand greatly predominating. The thickness of this surface deposit increases rapidly from the highland border eastward. At Newport, according to the record of a deep well near that city, on a farm owned by Mr. W. B. Chastain, it is 655 feet, that being the distance below the surface at which the Paleozoic rock was encountered. East of this point the thickness is not known.

\section{WATER RESOURCES.}

There are two natural divisions of the area under consideration which can be made on the basis of their water supplies-the Paleozoic and the Tertiary.

\section{PALEOZOIC REGION.}

The horizontal position and diversified character of the rock over the northern part of this region make the hydrologic areas conform to the areas over which water-bearing rocks are exposed or to their lines of outcrop. A detailed geologic map of the region would at the same time be a hydrologic map. Some of the water-bearing strata are exposed over large areas, others outcrop in practically horizontal planes along the hillsides. As it is not possible to present herewith a detailed geologic map, the hydrology of the Paleozoic region will be discussed under the following heads, which are somewhat arbitrarily chosen: The Ordovician area, the Boone chert area, and the Bos. ton Mountain area.

\section{THE ORDOVICIAN AREA.}

This occupies that part of the region under consideration over which the Ordovician rocks are exposed at the surface. As previously stated, these rocks consist mainly of magnesium limestone. From these rocks, where they are cut into by streams, emerge numerous strong springs. Among these is Mammoth Springs, in Fulton County, which is said to discharge 9,000 barrels of water per minute. ${ }^{a}$ As would be expected, the water of this region is hard, owing to the presence of the salts of calcium and magnesium in solution. The rocks are compact, and as a result the water can move only through joints and other fissures. For this reason the wells secure water only in case they strike a fissure. Some wells furnish an abundance of water, others, failing to strike fissures, are dry. The uncertainty of finding water in wells and the hard nature of the water have caused frequent resort to cisterns.

The most common method of sinking wells is by blasting out the rocks, but drilling is sometimes resorted to. So far as the chances of 
striking a fissure are increased by an increase of the well diameter, blasting is the most promising method. On the other hand, the chances for striking a fissure are greater in a deep well than in a shallow one, and as the cost of drilling a deep well is less than that of blasting, the former method is advisable in most cases. Especially is this true when the sanitary advantage of a well-cased drilled well over an open one is taken into consideration.

\section{THE BOONE CHERT AREA.}

The character, thickness, and wide outcrop of the Boone chert make it the most important water horizon in northern Arkansas. It is composed of limestone and numerous lenses of much-fractured chert. Beneath the Boone chert is a limestone from 25 to 50 feet thick, known as the St. Joe marble, but for hydrologic purposes the two may be considered together. Where not removed by denudation the Boone chert usually exceeds 300 feet in thickness. It is exposed over an area of about 3,600 square miles. Solution has removed the limestone from the upper part of the formation, but the chert, being insoluble, is left as a residue on the surface, in many places several inches thick. In such places this chert débris largely reduces the run-off from the rainfall, and by so much adds to the amount of water that enters the ground. The water descends through the joints in the limestone and is transmitted horizontally through the fractures in the chert lenses. Beneath the St Joe marble over a considerable portion of the area is the Eureka shale, which, being impervious, holds the water in the overlying limestone and chert. Along lines where streams have cut their valleys down to or beyond this bed of shale, springs with a copious flow of the best water are very numerous. Most of the famous springs at Eureka Springs emerge from this horizon.

In the western part of the State, over the Boone chert area, the divides between the streams are often flat, and in such cases water is easily secured by sinking wells a few feet, but in the eastern part, where the streams have cut far down into the Ordovician rocks and have left the Boone chert on the high divides between them, water is frequently below the level to which wells can be sunk by digging and blasting, the method usually employed. On account of the considerable depth of the water beneath these high divides the drill should be employed. By this method water could be obtained in most cases.

The water from the Boone chert, while hard, contains a smaller amount of matter in solution than might be expected, owing to the fact that so much of the formation is siliceous, and consequently insoluble. 
There are several water-bearing horizons in what is here designated as the Boston Mountain area. Named in their order, beginning with the lowest, the most important are: The Batesville sandstone, the Archimedes limestone, and the Pentremital limestone.

Batesville sandstone.-The Batesville sandstone is usually brown, and consists of medium-sized grains. It is commonly in layers from 2 inches to 1 foot thick, but in some places the beds are more massive. In the eastern part of the Paleozoic area it exceeds 100 feet in thickness, but gradually thins out in the western part of the State, where in places it is altogether wanting. In the eastern part of the region it lies upon the Moorefield shale, but in the western part of the State this shale is absent, and the Batesville rests directly upon the Boone chert. Where near the surface and of considerable thickness, it forms an important water horizon, as aboutGreen Forest, Carroll County, and at Batesville, Independence County. In both of these localities it furnishes excellent well water. At Batesville it was the chief source of water until waterworks were installed. As would be expected, the water from this horizon is soft.

Archimedes limestone.-The Archimedes limestone is a persistent formation, outcropping in an east-west direction across the Paleozoic area of the State, near the north base of the Boston Mountains. (See fig. 29.) In the eastern part of the region its thickness is 100 feet, but in the central and western parts it seldom exceeds one-fifth this amount. It is a compact limestone, composed largely of fossil remains. In places it contains lenses of chert, though these are not common. In the eastern and central parts of the area it rests upon the Fayetteville shale, a thick and impervious formation. In the western part of the State it is separated from the Fayetteville shale by

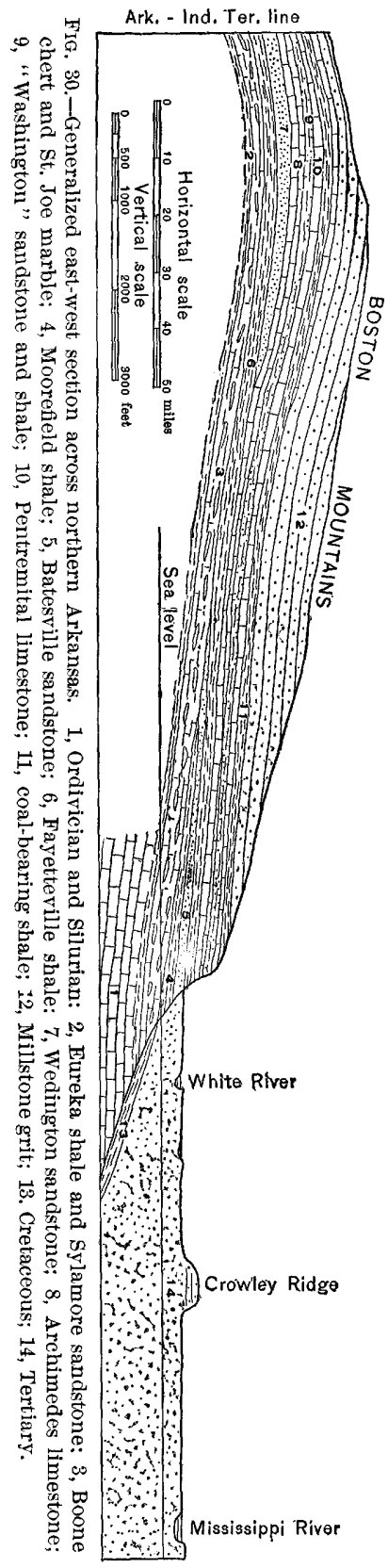
the Wedington sandstone, which also contains some shale. 
The massive nature of this limestone, which usually rests upon a bed of shale, causes it to form a conspicuous escarpment, from the base of which strong springs issue at frequent intervals. Below the escarpment, and upon the Fayetteville shale, is a bench from 100 yards to a quarter of a mile in width and of great fertility.

Pentremital limestone.-A bove the A rchimedes limestone (see fig. 29), and separated from it by a greater or less thickness of the "Washington" sandstone and shale, is the Pentremital limestone, which is also an important spring horizon, and which, like the one below it, is nearly every where productive along the north slope of the Boston Mountains. The water from both the last-named horizons is hard. Like most limestones, their texture is so compact that search for water in wells is not advisable.

The rocks at the tops of the Boston Mountains and of their outliers to the north are sandstone and shale. The sandstone varies in texture from medium-grained to coarse millstone grit. The porosity of the sandstone permits it to absorb a great deal of the rainfall, which is kept from sinking as underground water by the underlying impervious shale. As a consequence, the sandstones become important water-bearing strata, especially over the high, flat-topped table-lands between the heads of the mountain ravines. On these table-lands, water is easily secured from open wells. Springs frequently occur on the hill slopes, though they are neither so strong nor so numerous as along the Archimedes and Pentremital limestone horizons. Such springs are found over the large area covered by the Boston Mountains.

\section{ARTESIAN CONDITIONS IN THE PAI,EOZOIC AREA.}

In the lower plateal area the horizontal position of the strata pre. cludes the possibility of obtaining flowing wells, unless it be in local and limited areas, but near the north base of the Boston Mountains, in places where the rocks dip to the south, there may be small areas where flowing wells could be secured, the Boone chert being the source of the water.

An inspection of fig. 29 will at once suggest the possibility of securing artesian water along the Arkansas Valley. The Boone chert, which is widely distributed over the northern part of the State, and forms an excellent collecting area and through which the underground water is readily transmitted, dips south with the rocks of the Boston Mountains. Though the southward extent of this formation is not known, its thickness of more than 300 feet north of the Boston Mountains is good reason for supposing that it reaches beyond the Arkansas Valley. Over the collecting area its height is from 500 to 1,000 feet above the land along Arkansas River. Over it lie the heavy deposits of Moorefield shale and Fayetteville shale. All the conditions are favorable to this formation, being the source of an abundance of artesian water in 
the Arkansas Valley, provided there are not many faults with an eastwest strike between the Arkansas Valley and the catchment area. But it is known that faulting of the nature mentioned occurs here, and it is not improbable that it is sufficient to entirely cut off the southern flow of the water, thus destroying what would otherwise be excellent artesian conditions.

\section{TERTIARY REGION.}

The underground water of the lowland or Tertiary area has its source largely, probably mainly, in the rainfall of the region. The level surface holds the run-off in check, and sandy deposits take up a large amount of rain water, which is readily transmitted to all parts of its mass. Another source of water, unquestionably of great importance, is found in the streams which flow from the plateau region over the lowlands. When these streams are at low-water stage, the underground water moves slowly toward them from either direction. But when they are at flood stage, there is a large amount of leakage through the banks and into the loose, sandy material, for considerable distances in either direction away from the streams. The amount of underground water thus supplied to the lowlands from the Arkansas River, Little Red River, White River, Black River, and their tributaries, is problematical, but considerable. Another source of the underground water of this region is in the truncated edges of the Paleozoic rocks, beneath the younger deposits.

Owing to the low altitude, the uniformly level surface, and unindurated condition of the sediments, mainly sand, over the Tertiary area, an abundance of water can be secured almost anywhere by the expenditure of the small sum necessary to purchase from 10 to 40 feet of iron pipe, a point, a pump, and the few hours labor necessary to drive a well. The pump is usually of the kind known as the "pitcher pump," and the pipe is usually one and a quarter inches in diameter, sometimes common iron, sometimes galvanized. Because of the interlocking beds of sand and clay that in many places constitute the sediments near the surface, the depth at which water can be secured is uncertain, but it is seldom more than 40 feet. The water is most commonly raised by hand, though windmills are sometimes employed.

Formerly dug wells were the only source of water, and some of these are still in use, but they are rapidly being succeeded by driven wells. Bored wells are common in some localities. In a few instances these bored wells are cased with tile, carefully cemented at the joints to keep out the surface water, but wood is commonly employed for casing, a custom to be deprecated, as the decaying wood not only renders the water insanitary but permits the surface water to enter the well. Water for cities and ice plants is secured from bored wells 100 feet or more in depth. 
The amount of water that can be supplied by almost any well is limited only by the capacity of the pipe. In cases where a large amount is needed, as for boilers of large capacity, either a pipe of sufficient diameter is used or the number of wells is increased till the desired amount of water is secured. As a rule, the water is fairly well suited for boiler use, but in some cases it forms a troublesome scale, produced by the combined deposit of the mineral matter in solution and the fine material in suspension.

The character of the water varies greatly both with depth and horizontal distance. As regards the depth to which wells should be extended, no rule can be laid down except the general one that the deeper the well the better the water. This, however, is not by any means always true, for shallow wells often furnish better water than near-by deeper ones, as where the shallow wells are wholly in a surficial deposit of sand, while the deeper ones pass into mud, which contains a great deal of organic matter and salts of iron in solution. Frequently two wells of the same depth and only a few rods apart furnish water of an entirely different character. That of one may be of good quality, while that of the other is wholly impotable. This is. because near the surface there are horizontal variations in the character of the material, there being frequently intercalated deposits of mud containing a great deal of organic matter.

\section{ARTESIAN CONDITIONS IN THE TERTIARY AREA.}

The very small difference in altitude between the highest and lowest parts of this area would seem to preclude the possibility of securing artesian water in the Tertiary area, even though all the other conditions were favorable. In this area a well would probably have to pass through the Tertiary and into the Paleozoic rocks below. While the securing of artesian water from the Paleozoic horizon appears to be possible, the chances are against success. The southward dip of the Paleozoic rocks would bring these beds, if continuous, under the Tertiary deposits, in which case the chances of securing artesian water from them would be excellent. But those beds are truncated along the Tertiary-Paleozoic border to considerable depths (see fig. 30), permitting the water to leak into the younger rocks. Besides, the eastwest faulting of the Paleozoic rocks, probably cutting off the southward flow of the water, would be effective over the lowlands.

\section{MINERAL SPRINGS.}

The large springs of the limestone districts of the Paleozoic area have already been mentioned. Besides these there are a multitude of smaller springs, many of which yield mineral water of value for medicinal or domestic purposes. A considerable number of them have 
been developed as resorts, some of which are among the most important in the country. Sanitariums using spring water are common. The waters are generally used at the spring, but in 1902 seven springs reported sales amounting to 149,100 gallons, with a value of $\$ 52,575$. The springs reporting are as follows: ${ }^{a}$
Allen's Alterative Magnesia Spring, Hot Springs, Garland County.
Arkansas Lithia Springs, near Hope, Hempstead County.
Arsenic Spring, Hot Springs, Garland County.
Blanco Springs, near Hot Springs, Garland County.
Eureka Springs, Eureka Springs, Carroll County.
Potash Sulphur Spring, near Hot Springs, Garland County.
Ravenden Springs, Ravenden Springs, Randolph County.

\section{PRINCIPAL PUBLICATIONS.}

Mineral springs of the United States, by A. C. Peale: Bull. U. S. Geol. Survey No. 32 , pp. 118-122.

Preliminary list of deep borings in the United States, pt. 1, by N. H. Darton: Water-Supply and Irrig. Paper U. S. Geol. Survey No. 57, p. 12.

Arkansas [well and spring records], by A. H. Purdue: Water-Supply and Irrig. Paper U. S. Geol. Survey No. 102, pp. 374-388.

Summary of the water supply of the Ozark region in northern Arkansas, by G. I. Adams: Water-Supply and Irrig. Paper U. S. Geol. Survey No. 110, pp. 179-182. 


\section{TENNESSEE AND KENTUCKY.}

By L. C. GLenn.

\section{TENNESSEE.}

Topography.-In crossing Tennessee from east to west the following topographic divisions may be recognized: (1) The Valley of East Tennessee, (2) the Cumberland Plateau, (3) the Highland Rim or Plain within which the Nashville basin has been eroded, (4) the Western Valley of Tennessee River, (5) the Gulf Coastal Plain, and (6) the Mississippi Alluvial Plain or Bottoms.

Rainfall.-The rainfall is between 50 and 60 inches annually. In autumn, the driest season, it is 2 or 3 inches less than the average, and in winter, the wettest season, it is 2 or 3 inches more than the average; in spring it is slightly more and in summer slightly less than the average.

\section{VALLEY OF EAST TENNESSEE.}

Description.-The so-called Valley of East Tennessee is that part of the great Appalachian Valley that extends southwestward across the eastern end of the State from the Virginia to the Georgia line. Its width varies from 45 to 60 miles. It is limited on the southeast by the Great Smoky Mountains along the North Carolina line, and on the northwest by the eastern scarp of the Cumberland Plateau. The floor of this valley has an elevation of 900 feet at Chattanooga and of 2,000 feet along the Virginia line. Many long, narrow, parallel ridges trending northeast-southwest in the same direction as the valley itself rise above its floor. They are separated by long, narrow, minor valleys. The ridges are formed by the hard, upturned, folded and faulted Cambrian, Silurian, and Devonian rocks, while the intervening valleys have been eroded in the limestone or soft shale.

Water resources.-Along the eastern side of the valley the Great Smoky Range, which reaches an extreme height of over 6,500 feet, is carved along with its projecting spurs either from metamorphosed sediments of probably Cambrian age or from more ancient igneous rocks of various kinds. Among these spurs many bold freestone springs are found, and every ravine has its streamlet of pure, clear, 
and unfailing water. The region is rough and sparsely settled, and the springs furnish an abundant and satisfactory water supply.

In the valley proper the streams are usually broad, shallow, and rapid. Their waters are generally pure and clear, except after heavy rains. Innumerable springs are found throughout the valley. Because of the great variety in the rocks of the region the water of the springs varies greatly in character. From the limestones and dolomites large and bold springs of clear, hard but wholesome, water issue constituting the most common supply for household purposes. The waters often contain magnesian salts where the springs issue from the Knox dolomite. In general it may be said that their chief mineral contents are calcium, magnesium, and sodium carbonates, sulphates and chlorides, with occasionally iron sulphate and carbonate or aluminum sulphate or alum. Many sulphur, iron, and alum springs are found in the Devonian black shale. Sulphur waters are also found in the limestones and dolomites. Chalybeate waters occur in the sandstones and conglomerates, though freestone waters are more common. In several counties Epsom springs are known.

Some of these valley springs have earned a wide reputation for their medicinal qualities, and annually attract many visitor's in search of health, recreation, or rest. A few ship their waters.

In some cases these natural supplies are supplemented by cisterns, though the abundance of springs and their unfailing flow, no doubt largely due to the faulting of the rocks, render the use of cisterns less necessary than in many limestone regions. In those towns which are without a system of waterworks the use of cisterns is more prevalent, as they furnish the only safe water supply under such conditions. In the larger cities water supplies are obtained from near by rivers or other smaller streams. Although the valley is well settled the population is largely agricultural and scattered, and stream supplies may be regarded as safe except where contaminated by tan bark, wood pulp, or other similar industries.

\section{CUMBERLAND PLATEAU.}

Description.-The Cumberland Plateau crosses Tennessee in a northeast-southwest direction, and varies in width from about 35 miles near the Alabama line to about 50 miles near the Kentucky line. Its elevation is 1,500 feet on the Alabama line, 2,000 feet in the center of the State, and 3,500 feet near Cumberland Gap. The plateau surface stands about 1,000 feet above the adjacent regions on either side. The eastern edge is an abrupt scarp that is straight for miles. The western edge is an equally abrupt scarp, but is notched by the headwaters of streams that have eaten into the plateau from the west. The surface, while measurably flat, is diversified by shallow valleys and low ridges. 
Water resources.-The rocks of the plateau are of Carboniferous age. Much of the surface is underlain by sandstone, which forms an open porous soil if well drained. From this sandstone issue the numerous freestone springs that furnish so large a part of the water supply of the region. During summer and fall droughts sometimes occur, and many springs and streams decrease in volume or go entirely dry, so that water for household use and for stock becomes scarce while the small mills for grinding corn remain idle until rains set in. Open wells supplement the springs in many instances.

Supplies of water may be obtained by drilling a few hundred feet into the thick sandstone beds that underlie the larger part of the plateau. Such waters will not usually flow, but will rise within easy pumping distance of the surface. They may contain more or less iron from the sandstones or sulphur from the interbedded shales and coals. Wells drilled deeper into the underlying Mississippian or Silurian limestones or into the Devonian black shale usually obtain salt water, with greater or less amounts of natural gas or petroleum.

There are numerous chalybeate springs on the plateau, some of which are of local repute as summer resorts. Although none have been improved to any extent, the clear, cold, freestone waters, combined with the elevation and delightful summer temperature, bring many visitors from the lowlands during the heated season.

Much of the plateau is underlain by workable coal and mines are being opened at numerous places, each of which becomes the nucleus for the development of a mining town. With its growth the quality of its water supply, usually taken from open wells and springs, will deteriorate.

\section{HIGHLAND PLAIN.}

West of the Cumberland Plateau lies the Highland Plain, which extends westward to Tennessee River. The width of this plain is about 175 miles along the Kentucky line and 105 miles along the Alabama line. Its average elevation is approximately 1,000 feet. Viewed broadly, its surface is level; viewed in detail, it is gently undulating or cut by small streams into narrow but sometimes steep-sided valleys. In a few places the larger rivers, including the Cumberland, Duck, and Elk, have cut steep-walled valleys 300 or 400 feet deep and have eroded out of the very center of the Highland Plain a great oval basin 120 miles long and 50 broad, whose comparatively flat bottom is 300 to 400 feet below the encireling plain. This basin is known as the Nashville or Central basin and will be discussed in a subsequent paragraph.

\section{PLATEAU REgION.}

Description.-The siliceous beds of the Mississippian form the surface of the Highland Plain. These beds consist of limestones, siliceous 
shales, and chert. As they form the surface of this plain they have been exposed to the leaching action of the water so long that the calcareous matter has been removed to a considerable depth and the surface is a disintegrated mass of reddish clay and porous chert.

Water resources. - The waters of the Highland Plain are mostly of he clear freestone type, although some are chalybeate from the iron contained in the chert. Where the lime has not yet been entirely leached from the rocks the waters may be hard. Many springs are found on the Highland, although in numerous areas springs are weak or wanting, or fail during dry seasons. Many of the smaller streams dry up also. In such places deep drilling generally gives a water containing objectionable quantities of calcium and magnesium carbonates and sulphates, hence the main dependence for potable water in such cases must be cisterns, of which many are in use.

Along the eastern margin of the Highland Plain at the foot of the escarpment which rises to the Cumberland Platean many very large springs flow from the outcrop of the flat-lying Mississippian limestones underlying the sandstones of the plateau. These limestones receive a considerable part of the drainage which emerges along the edge of the Highland Plain in streams, many of which are large enough to turn a mill where they issue from their underground channels.

In the portion of the Highland area adjacent to the central basin are many sulphur springs, while on the steep slopes between the two the springs from the outcropping black Devonian shale contain sulphur, iron, and in some cases alum. No extensive area of this slope is made up of black shale, however, as it varies from only a few feet to 20 or 30 feet in thickness. Some of the sulphur and other mineral springs on the Highland and on the slope into the basin have beeen improved and have considerable reputation as summer resorts.

\section{NASHVILLE BASIN.}

Description.-The strata of the central portion of the Highland Plain have been arched into a low oblong dome which Elk, Duck, and Cumberland rivers have eroded until they have cut through the Mississippian and Devonian and into the softer limestones and shales of the Silurian. These have been in turn eroded, resulting in the undermining of the overlying rocks of the Highland Plain and the final formation of a basin of the dimensions already given. The bottom of this basin is flat or gently rolling. It slopes somewhat toward the Cumberland and other main streams and has some isolated knobs that rise to nearly the height of the adjacent Highland, while from the rim spurs project into the basin.

Water resources. - The Silurian limestones that form the floor of the Nashville basin dip away from its center in all directions, but at such IRR $114-05-14$ 
a low angle that they appear nearly flat. Many springs are found in these limestones, some of them being very large. They furnish clear, cold, hard water as a rule, though some of them contain sulphur. During the dry seasons many of the weaker springs and smaller streams go dry and difficulty is found in securing water supplies. Cisterns are extensively used, especially for housebold purposes, while ponds are dug or small streams dammed to secure water for stock. This region is the most fertile and most thickly populated in the State. Some cities, such as Nashville, get their water supply from rivers, others obtain water from deep wells which are pumped, while others without waterworks depend mainly on cisterns.

No persistent horizon of potable deep waters is known to underlie the basin surface. Water may be obtained almost anywhere by drilling a few hundred feet, but it is usually strongly impregnated with sulphur or is salty. In the lowest part of the basin the deep wells may flow. Several of the deep wells in Nashville are strongly sulphurous. Wells in other parts of the basin sometimes give off small quantities of natural gas, or are greatly injured by a slight exudation of petroleum. Many other wells, especially if not deep, furnish good water.

\section{WESTERN VALLEY OF TENNESSEE RIVER.}

The Highland Plain is bounded on the west by the western valley of Tennessee River, a north-south valley 400 to 600 feet deep and 8 or 10 miles wide. The rocks making the floor and most of the walls of the valley are Silurian limestones and shales, though Devonian, Mississippian, or even Cretaceous and Lafayette may in places form part of the wall. Iron and sulphur springs are numerous along the outer edges of the valley floor and in several places wells drilled years ago for salt yield an abundant flow of sulphur water, which is said to possess valuable medicinal qualities.

\section{GULF COASTAL PLAIN.}

Description.-The Gulf Coastal Plain extends from the Tennessee Valley westward to the bluffis overlooking the Mississippi River flood plain. Its width along the Kentucky line is about 65 miles; along the Mississippi line it is 105 miles. From an elevation of 600 to 800 feet in its southeastern portion its surface slopes west and northwest to an elevation of 270 feet at Memphis, and from 300 to 400 feet in the central and northwestern part of the area and along most of the bluff north of Memphis. The rocks of the region are unconsolidated sands and clays dipping gently westward, their lowest members outcropping in a narrow north-south belt just west of Tennessee River. The topography of the sandy formations is usually rolling to hilly, while 
that of the clays and loams is often flat when remote from streams, but hilly when near them.

Geology and water supply.-The oldest rocks of this region are the Coffee sands of Cretaceous age. They outcrop in a belt that has an average width of perhaps 4 miles and extends northward from Mississippi halfway across the State along the eastern edge of the Coastal Plain region. They overlap the Paleozoic rocks exposed in the western valley of the Tennessee. The best exposure is at Coffee Landing, on the Tennessee, where they consist of fine micaceous sands and thinly laminated dark clays with abundant lignitic material. Their base is not exposed here, but slightly over 200 feet were seen. The total thickness can not be much more than this. Westward they dip under the Rotten limestone, which is also of Cretaceous age. This latter consists of green sand and fine-grained joint clay of a leaden color and often contains an abundance of fossil shells. It forms a belt 8 or 10 miles wide extending northward from Mississippi; also halfway across the State. Its maximum thickness, 350 feet, is found along the Mississippi line, but it thins rapidly northward. The water obtained from springs and wells is in most places hard and disagreeable in taste and odor. Good water may be obtained, however, by going through it into the Coffee sand. Many such wells exist. They vary in depth according to location, the deepest being about 350 feet. Water rises nearly to the surface as soon as the Coffee sand is reached and is generally of good quality.

Next westward is a belt of sands and clays, which where they enter from Mississippi are 12 to 15 miles wide, but only about 6 miles wide where they pass into Kentucky. They are known as the Ripley beds, are of Cretaceous age, and dip gently westward. Their thickness is perhaps 400 to 600 feet. Their surface is usually hilly. They are water bearers, but open wells may go 80 to 100 feet deep for water, though in lower ground 40 to 60 feet is a common depth.

Above the sands and clays of the Ripley beds, the latest of the Cretaceous formations, lies the Porters Creek (Flatwoods) clay. This clay is of early Eocene age, and consists of light, leaden-gray clays, with occasional laminæ of fine micaceous sand. The lower part contains beds of micaceous sand, greensand, and some thin impure limestones. The formation probably has an average thickness of more than 200 feet, and extends from Mississippi northward across the State in a belt 5 or 6 miles wide. The water derived from it is not of good quality. Better water may be had by going through it and into the underlying Ripley sands.

The "Lignitic" group rests on the Porters Creek formation and extends westward across two-thirds of western Tennessee to the bluffs overlying the Mississippi. It is composed chiefly of sands, in which 
occur, especially in the eastern part of the area of outcrop, numerous lenses of plastic clays. In the western part of its area the upper part of the "Lignitic" is frequently marked by a bed of blue or dark lignitic clay about 150 feet thick. The total thickness of the "Lignitic" is 750 feet at Memphis. Its sands are water bearing throughout, but as they vary much and rapidly in coarseness, and consequently in quantity of water they can furnish, the proper depth of wells sunk into them must be determined by trial. Usually their lower part is the coarser, and the quality of the water yielded is generally suitable for any desired purpose. This group is by far the most valuable water-bearer in western Tennessee.

The Lafayette is spread as a thin blanket over all the preceding western Tennessee formations. It is a series of sands, clays, and gravels that are prevailingly red or orange in color and usually hardened, while in some places the sands have become cemented by iron into sandstones. The beds probably never exceed 50 feet in thickness and are more frequently less than 20 feet thick. Along the Tennessee and Mississippi River bluffs this formation consists very largely of gravel, while away from the neighborhood of these streams the gravel beds are thin or often wanting. When underlain by clays water is usually found at the base of the Lafayette. 'Along such of the stream valleys as cut through it numerous springs issue from these basal beds, while shallow wells may reach it anywhere. The water is usually good, provided the well is stopped in the Lafayette sand, but if it enters the top of an underlying clay or marl bed it is often poor. Over most of the region, however, the Lafayette rests on the "Lignitic" sands, and its base is then only locally water bearing, one well obtaining water while another only a few yards away may find none.

Loess overlies the Lafayette gravel in a belt 12 to 25 miles wide, extending north and south across the State. The thickness gradually decreases from 20 to 70 feet in the bluffs overlooking Mississippi River to an indefinite feather edge to the east. The loess is everywhere calcareous and wells sunk in it yield hard water. It naturally forms a rich soil and population is denser in this belt than elsewhere in western Tennessee. Many people in the loess region use cisterns, which are easily and cheaply constructed in the loess. Water of better quality may be obtained by deeper wells, drawing their supplies from the underlying sands of the "Lignitic."

Resting on the loess, and at times separable from it only with difficulty, or lying east of the loess belt and resting on the Lafayette, is a veneer of loam, clay, or sand that reaches in places perhaps 10 feet in thickness. It has generally been correlated with the Columbia. It is not of importance as a water-bearer. 
MISSISSIPPI ALLUVIAL PLAIN.

In the flood plain of the Mississippi River the deposits are recent silts. These contain water at slight depths, but it is of poor quality. Its level rises and falls with the varying stages of the river. Good water may be obtained from the underlying lignitic by deep boring. Cisterns are also used, though the soft alluvial deposits are not always solid enough to prevent the walls of the cisterns from cracking.

\section{COMMERCIAL SPRINGS.}

The following springs reported sales of water in the year 1902: ${ }^{a}$

Eastbrook Springs, Eastbrook, Franklin County.

Hinson Springs, Hinson Springs, Henderson County.

Horn Mineral Springs, Horn Springs, Wilson County.

Idaho Springs, near Clarksville, Montgomery County.

Larkins Spring, Madison, Davidson County.

Lockeland Spring, East Nashville, Davidson County.

Montvale Spring, Montvale, Blount County.

Red Boiling Springs, Red Boiling Springs, Macon County.

Rhea Springs, Rhea Springs, Rhea County.

Tate Epsom Spring, Tate Spring, Grainger County.

Whittle Springs, Whittle Springs, near Knoxville, Knox County.

Willow Brook Spring, Craggie Hope, Cheatham County.

Wright's Epsom Lithia Well, Mooresburg, Hawkins County.

The aggregate amount sold is stated as 247,429 gallons, valued at $\$ 36,315$.

\section{PRINCIPAL PUBLICATIONS.}

Mineral springs of the United States, by A. C. Peale: Bull. U. S. Geol. Survey No. 32 , pp. 97-106.

Preliminary list of deep borings in the United States, pt. 2, by N. H. Darton: WaterSupply and Irrig. Paper U. S. Geol. Survey No. 61, p. 49.

Tennessee [well records and spring records], by L. C. Glenn: Water-Supply and Irrig. Paper U. S. Geol. Survey No. 102, pp. 358-367.

\section{KENTUCKY.}

Climatic conditions in Kentucky are much the same as in Tennessee. The topographic belts which are found in Tennessee extend northward into Kentucky, and the geologic formations of the two States are very similar. The water resources of Kentucky accordingly resemble those of Tennessee in corresponding topographic regions, so that much already said concerning the hydrographic characteristics of these belts in Tennessee applies equally well to Kentucky. 
[No. 114.

\section{CUMBERLAND PLATEAU.}

The most eastern topographic division of Kentucky is the northward continuation of the Cumberland Plateau region of Tennessee. In Kentucky the flatness of the plateau surface, however, has disappeared, and in its stead the region is deeply dissected by streams, so that the actual surface consists of a maze of steep-sided mountains separated by almost. equally narrow, steep-walled valleys. The plateau surface is represented only by the uniform altitude of the mountain crests. The southeastern edge of the plateau has an elevation of 3,500 feet, and is sharply defined by the Cumberland Mountain scarp. The western edge of the plateau has an elevation of 1,500 feet in the south, and of 900 feet along Ohio River. In Kentucky the plateau is not sharply defined on the west, but falls away in isolated projecting spurs of irregular but not great height, extending out toward the next and lower topographic division, the Lexington Plain.

The rocks of the plateau are horizontal Carboniferous sandstones and shales. Springs abound, and while in dry summers many of them, and even the smaller streams, dry up, there is generally an adequate supply of water. Some shallow open wells are used, but they furnish an insignificant part of the water supply. Some of the springs, especially such as flow from coal horizons, contain iron or sulphur. These may also at times contain alum. Population is sparse, houses are well scattered, and the springs are usually safe and wholesome. Even the simplest of sanitary precautions are, as a rule, unheard of, and occasionally water is used from a pool or branch that is utterly unfit for drinking, and doubtless the cause of a considerable amount of sickness.

\section{LEXINGTON PLAIN.}

The Highland Plain of Tennessee extends northward into Kentucky, where it is known as the Lexington Plain. In detail its elevation varies considerably but it may be taken as averaging 1,000 feet in its eastern and central parts and 800,600 , or even 400 feet along Ohio River. The surface of much of this Lexington Plain is composed of Mississippian and Devonian sandstones, shales, and limestones.

In sandstone regions the water is usually soft, and springs are more abundant and constant than in the shale or limestone areas. In the Devonian black shale, sulphur, alum, and copperas springs are often found. In the limestone areas much of the drainage is underground, and at many places big springs occur, some of which are so large that they furnish an abundant supply of water for good-sized towns. Such waters are hard.

In the north-central portion of this Lexington Plain there is an ovalshaped area of 10,000 square miles with Frankfort almost in its center that is composed of Silurian limestones similar to those of the Nash. 
ville basin. Much of the drainage is underground, the water is hard, and springs are scarce in some portions. Water may be obtained by drilling generally at very moderate depths but it almost always smells slightly of petroleum or contains salt or other mineral matters rendering it unfit for domestic purposes. Streams dry up in the summer and ponds are dug to hold water for stock. Cisterns are very largely used.

Numerous mineral springs are found in the limestone region, some of which are noted health and summer resorts. They usually contain sulphur, iron, salt, or calcium and magnesium carbonate and sulphate.

In western Kentucky, on either side of the lower part of Green River, Carboniferous sandstones and shales are exposed in an oval area of 4,000 square miles which belongs topographically to the Lexington Plain but whose water supplies are in general much like those of the Cumberland Plateau region. Stream cutting has not been so deep as in the eastern part of the State and springs are somewhat less abundant, although sulphur and iron springs are numerous.

\section{GULF COASTAL PLAIN.}

That part of Kentucky which lies west of Tennessee River is known as the Jackson Purchase region. It is an area of unconsolidated sands and clays belonging to the Gulf Coastal Plain and forming a continuation of the similar area in western Tennessee.

Of the Cretaceous formations of Tennessee only the youngest, the Ripley, extends north into Kentucky. The Ripley sands and clays lie within 3 or 4 miles of Tennessee River and form a belt 5 to 10 miles wide. The formation is porous and open and becomes very dry during summer, so that open wells must frequently be sunk to a depth of 80 to 100 feet to insure adequate supplies. Cisterns and artificial ponds are extensively used. On the west the Ripley formation dips beneath the Porters Creek (Flatwoods) clay (basal Eocene), which gives more of a flatwood aspect to the topography here than it does in 'Tennessee. As in Tennessee, the water found in it is hard, "flat tasted," and not abundant. The thickness of the Porters Creek clay in Kentucky is not known, but it is probably not over 200 feet. It forms the surface in a belt 5 to 15 miles wide. Better water could be obtained in this area from the underlying Ripley sands, but the water probably would not flow except in very low places, though it would commonly rise nearly to the surface.

The western three-fifths of the Purchase region is composed of "Lignitic" sands and clays in which the coarser sand beds are water bearing. They are of variable character, however, and no one coarse stratum seems widely persistent. In the eastern part of the "Lignitic" area good water should be found within 200 to 300 feet of the surface. At Mayfield, for example, excellent water is obtained at a depth of 250 
feet. Near Mississippi River the depth will increase to 500, 600, or 700 feet, and the sands tend to become finer and less reliable as water bearers.

Lafayette sand and gravel, loess, Columbia loam, and Mississippi flood-plain alluvium all occur very much as they do in Tennessee, and bear similar relations to water-supply problems.

\section{COMMERCIAL SPRINGS.}

The following springs reported shipments of water in 1902: ${ }^{a}$

Anita Spring, Lagrange, Oldham County.

Bedford Springs, Bedford, Trimble County.

Bluelick Springs, Bluelick Springs, Nicholas County.

Crab Orchard Springs, Crab Orchard, Lincoln County.

Upper Bluelick Springs, Nicholas County.

The aggregate sales are given as 169,750 gallons, valued at $\$ 21,537$.

\section{PRINCIPAL PUBLICATIONS.}

Mineral springs of the United States, by A. C. Peale: Bull. U. S. Geol. Survey No. 32, pp. 106-118.

Preliminary list of deep borings in the United States, Pt. 1, by N. H. Darton: Water-

Supply and Irrig. Paper U. S. Geol. Survey No. 57, pp. 47-49.

Kentucky [well and spring records], by L. C. Glenn: Water-Supply and Irrig. Paper U. S. Geol. Survey No. 102, pp. 369-373.

Water resources of the Middlesboro-Harlan region of southeastern Kentucky, by G. H. Ashley: Water-Supply and Irrig. Paper U. S. Geol. Survey No. 110, pp. 177-178. 


\section{MISSOURI.}

\section{By Edward M. Shepard.}

\section{GENERAL CONDITIONS.}

Missouri has an abundant supply of potable waters, which, for the most part, come to the surface in springs generously scattered over a large portion of the southern half of the State, and to a less degree over the northern half.

North of Missouri River the country is covered by glacial drift, varying from a few feet to 150 feet in thickness. In this area the springs are small, but they occur frequently where erosion has cut into the drift, which thus becomes the main reservoir for the wells and springs of the region.

South of Missouri River the country is destitute of drift, but erosion has cut deep valleys along the borders of the Ozark Plateau, and in such localities some of the largest and finest springs of the country abound.

\section{TOPOGRAPHY.}

Topographically, Missouri may be naturally divided into four great districts: (1) the Northwest Plateau, (2) the North-Central Plain, (3) the Ozark-St. Francis Dome, and (4) the Southeastern Lowlands, all of which are outlined on fig. 33 .

The first district, the Northwest Plateau, includes the elevated portion in the northwestern third of the State, and is bounded on the southeast by the 900 -foot contour. This plateau rises gently to the northeast corner of the State, where an elevation of over 1,200 feet is reached. The strata generally dip from 10 to 15 feet to the mile, in a northwesterly direction, thus burying to a considerable depth the Coal Measures which outcrop on the southern border of the district.

The south boundary of the second division, or the North-Central Plain, starts arbitrarily on Mississippi River in St. Charles County, runs southwesterly until it joins the north boundary of the Ozark-St. Francis Dome (at approximately the 900 -foot contour) in Franklin County, which it follows to the northwest corner of Barton County on the Kansas line.

The Ozark-St. Francis Dome district is included in the large area between the last-described line and a line extending southwest from 
Cape Girardeau to the Arkansas boundary, following the 400 -foot contour.

The Southeastern Lowdands include the southeastern corner of the State south of the 400 -foot contour, and nowhere have an altitude much exceeding 400 feet.

\section{GEOLOGIC CONDITIONS.}

The Northwest Plateau is covered wholly by drift, which is underlain by the Lower and Upper Coal Measures. The North-Central Plain is partially covered by drift in the northeast, and underlain by Mississippian and Lower Coal Measures, with a fringe of Devonian

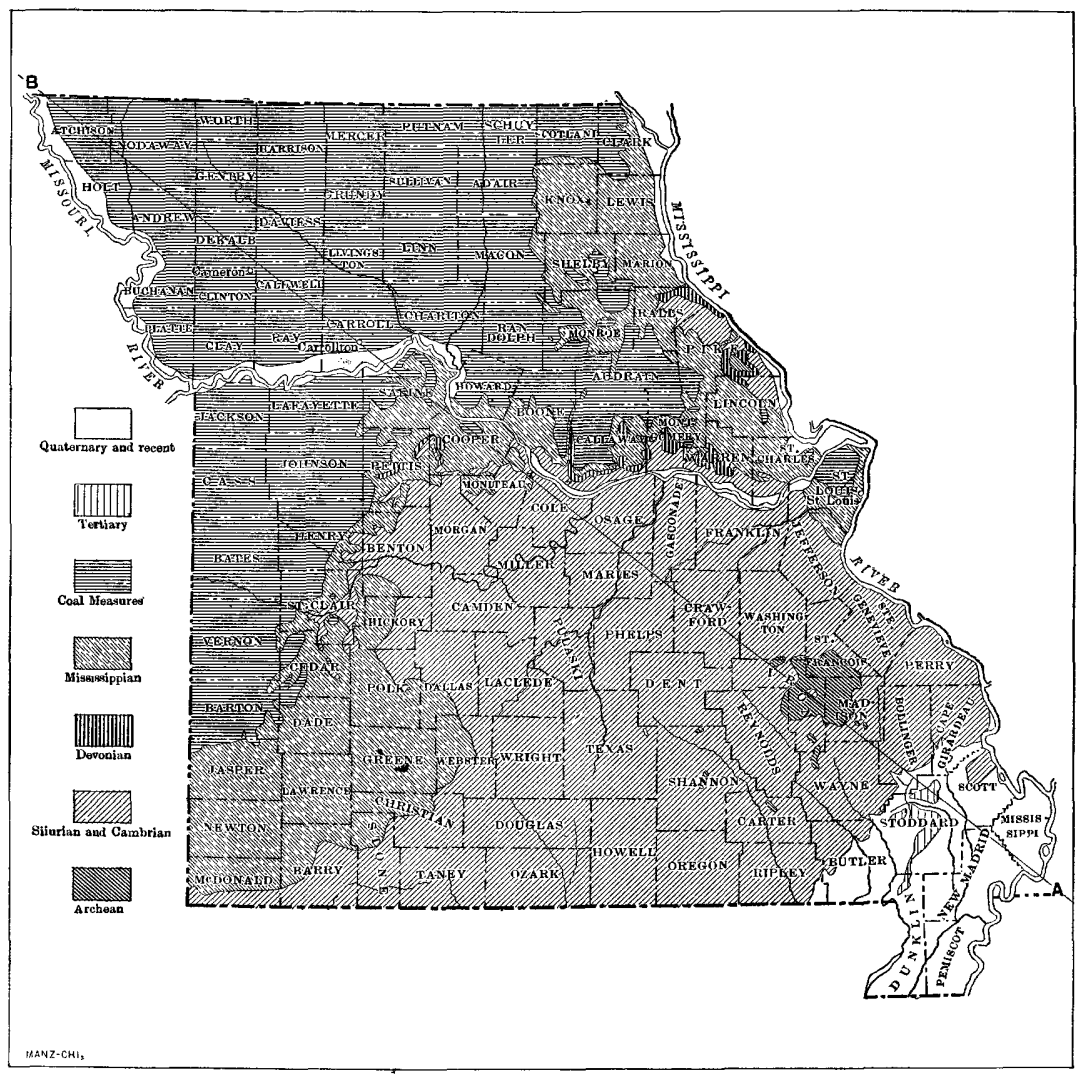

FIG. 31.-Geologic sketch map of Missouri.

and Silurian on the easter'n border. The Ozark-St. Francis Dome varies greatly in altitude and in geology. The St. Francis Mountains are made up of Algonkian granite and porphyry. The greater portion of the Ozark region is underlain by Cambrian rocks, composed of alternating beds of dolomites and sandstones. The southeastern lowlands are underlain almost entirely by the sands, clays, and gravels of the Tertiary. 


\section{CHARAC'TER OF THE WA'TER SUPPLY.}

\section{NORTHWESTERN PLATEAU DISTRICT.}

The rocks underlying this district belong entirely to the Lower and Upper Coal Measures. The underground water supply of this region is mainly derived from the drift. In the counties bordering the Missouri River, especially Atchison County, small springs are frequent in the bluffs, often occurring one-third of the way to the top. They are also frequent along the valleys of many of the streams. In the greater part of this district drills bave shown that the basal stratum of the Coal Measures is a porous sand rock containing occasional beds of bituminous shale, similar to the shale and sandstone forming the basal member (Cherokee shales) of the Coal Measures elsewhere in the State. An abundant supply of water is nearly everywhere obtained from this sandstone by drilling, as is shown by well records furnished by Mr. R. Hawkins, of Chillicothe.

The water from this stratum in widely different localities uniformly carries about 400 grains of salt to the gallon, with some iron, and occasionally sulphur. Mr. Hawkins states that farmers in this area agree that this is very good water for live stock. The pressure is sufficient in Livingston and adjoining counties to cause the water to rise 725 to 740 feet above sea level. Along Grand River bottom the water flows sluggishly out of the wells. As the rocks dip irregularly to the west and north from 10 to 15 feet to the mile the approximate depth of the water stratum may be calculated if the surface elevation is known and allowance is made for the local disturbances producing irregular folds in the strata. The water-bearing stratum varies from 20 to 70 feet in thickness and furnishes an abundant supply of water. Below this water level of the Cherokee shales and sandstones are other water-bearing strata, but, as a rule, they become more highly impregnated with mineral

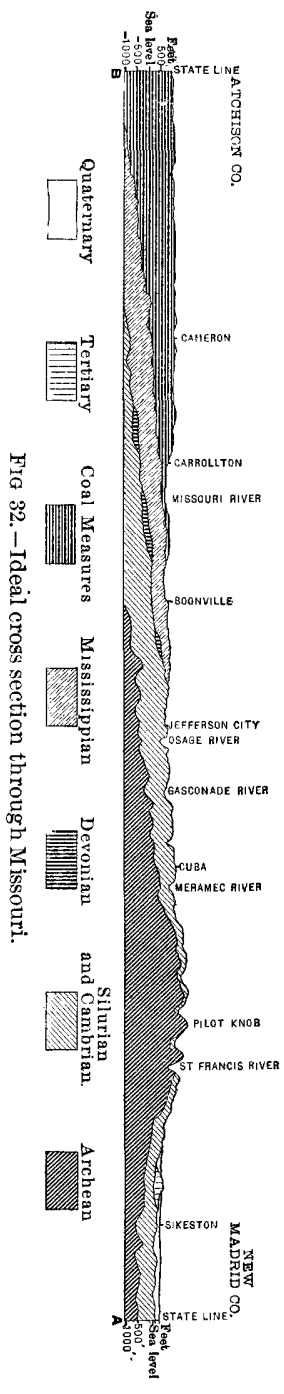
salts as the depth increases, until they are no longer potable.

A few small artesian districts are found in this area. At Tarkio, Atchison County, are seven small flowing wells, varying in depth from 196 to 220 feet. Some of these furnish the city with water. They are evidently derived from higher reservoirs in drift gravel, overlain by an impervious 
clay layer. Another flowing well at Bethany, 684 feet deep, furnishes water for the Heilbron Sanitarium. It flows a gallons per minute. The source is near the bottom of the well, in the Upper Coal Measures. Another flowing well is reported at Gallatin, Davis County, which probably obtains water from the Upper Coal Measures. There is also a flowing well at G. H. Lawson's, near Utica, Livingston County. The surface elevation here is about 750 feet. The water is saline, and derived from sand rock of the Cherokee shales. The well is 421 feet deep, and drilling was stopped in Mississippian limestone. The water flows sluggishly from the top. There

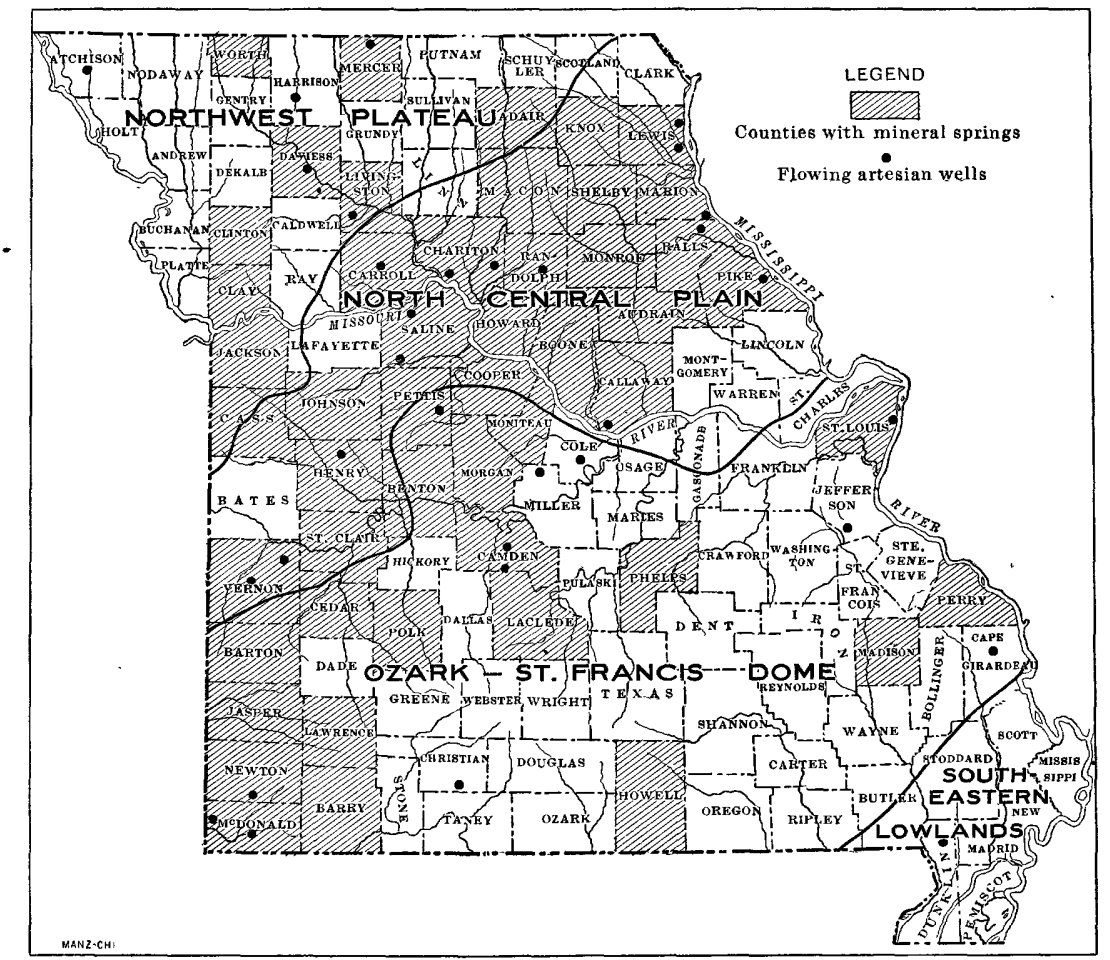

FIG. 33.-Sketch map of Missouri, showing water resources.

are a number of mineral springs and drilled wells supplying mineral waters in this district, some of which have a national reputation. One of the most noted and popular of these is Excelsior Springs, in the northeast corner of Clay County, about 30 miles northeast of Kansas City. In the group of springs at this place the best are the Regent and Siloam springs, both ferromanganese waters, derived from the Coal Measures shales. Two drill wells--the "Sulpho-saline," 1,460 teet deep, and the "Salt-sulphur," 1,370 feet deep-have been sunk in this vicinity, furnishing sulpho-saline waters. No record of these two wells has been preserved, but the writer believes that the waters 
are derived from the Jefferson City limestone (Second magnesian, of Swallow). The waters are carbonated and shipped to all parts of the country. Winslow has shown ${ }^{a}$ the similarity of the Excelsior Springs waters to those of St. Moritz and Mont d'Or in Switzerland and France.

Cities in this district generally derive their water from adjacent rivers. Wells and cisterns are the most common source of potable water. The former areshallow, from 20 to 50 feet deep, and generally have an abundant supply of water from the drift gravels. Broadhead makes the following statement: ${ }^{b}$ "Wherever limestone No. 78 [Bethany limestone] of the Upper Coal Measures prevails we may expect good streams of water just beneath. Springs of any kind are not common in either the Middle or Lower Coal Measures, but are more frequently found where the Upper Coal Measures prevail."

\section{NORTH-CENTRAL PLAIN DISTRICT.}

The greater part of this district is underlain by Lower Coal Measures and Mississippian rocks. Fresh-water springs are not very common, especially in the Lower Coal Measures. Salt and mineral springs, some of unusual size, abound. As regards the distribution of underground waters, the district is naturally divided into three sections - the eastern, middle, and southern. The eastern section is largely overlain by drift. Small springs are found at the base of rounded hills of drift and occasionally along outcroppings of the Burlington and Louisiana limestones, and in Warren County good springs are found at the base of the St. Peter (First) sandstone. The main dependence for water in this section, however, is in shallow wells in the drift and in cisterns. In the central section fresh-water springs are rare, and potable water is mainly derived from wells and cisterns, the wells being dug in loess, where that formation occurs. Good water mayalso be found in the limestones of the Henrietta or the sandstone of the Marais des Cygnes (Pleasanton) shales. This section is noted for the enormous brine springs which are so frequent in Saline and Howard counties. Around some of these brine springs buffaloes in the past have licked away the soil to a remarkable degree. At McAllister Springs is an old buflalo lick, where a valley approximately 25 feet deep, 200 feet long, and 100 feet wide has been excavated. These springs have become popular resorts.

The Big Salt Spring, in Saline County, is a remarkable example of one of these brine springs. The surface rock is near the base of the Mississippian, and the spring proper is an oval pool abont 25 feet in diameter. The water boils up all orer the surface of this pool, and is impregnated with sulphur. Its source is undoubtedly at a great depth. 
This spring exhibits a curious fluctuation in temperature. Meek described it in 1855, in his Geological Report on Saline County, as having a temperature of $60^{\circ}$, and as containing an abundance of sulphureted hydrogen. Woodward visited it in 1890 and in his report on The Mineral Springs of Missouri described it as having a temperature of $56^{\circ}$, with little or no sulphureted hydrogen. The present writer visited it in 1903 , when he found the temperature to be $64^{\circ}$, with considerable sulphureted hydrogen. Data from these three observations also indicate a steady decrease in the flow of this spring. The temperature obtained by Meek in springs in other localities checks closely with the data obtained by the present writer; therefore the variation is probably not due to difference in thermometers. Meek describes another brine spring adjoining this one as subject to sudden large fluctuations in flow, independent of rains or droughts. He states, "I had the satisfaction to see it in the act of rising. The water was seen to suddenly rise and flow out over perfectly dry ground." This central section seems to be a basin which receives the flow from the Ozarks from the southeast, being apparently inclosed on the south by the Sedalia fold, and probably on the west by smaller folds which have not yet been fully outlined. If this view can be fully verified it might account for the concentration of salines in these waters. The presence of a considerable amount of calcium chloride in all the deep wells and brine springs of this district would presuppose the theory that this was a basin early shut off from the sea, in which the original sea water became concentrated. This section is the most prominent artesian region in the whole State, and will be referred to later. The southwestern section of this North-Central Plain contains a few weak springs, and these are frequently impregnated with alum, sulphur, epsom salts, and sometimes with ferrous sulphate. These are especially noted in Bates, Vernon, and Barton counties. They are mainly derived from the Cherokee shales, which are frequently pyritiferous and magnesian. A number of valuable chalybeate springs are found in this section; they issue from the basal sandstone of the Cherokee shales.

As before stated, this North-Central Plain contains the main artesian areas of the State. In the eastern section of the district an artesian belt extends along the eastern slope of the Winfield-Rensselaer fold. The writer has traced this fold as far north as Rensselaer and believes it to extend still farther north into Lewis County. At Canton, in Lewis County, is an artesian well 906 feet deep, which was sunk in 1890. The first flow of water was struck at 870 feet, in the St. Peter sandstone (First sandstone of Swallow). Sixty feet of this porous sandstone was passed through in the bottom of this well. A gage at the mouth of the well indicates a pressure of 12 pounds. This well supplies the city with water and is leased by Messrs. Griffith and Maggard, who ship large quantities of the water abroad. This is 
one of the finest sulpho-saline waters in the State. The well is located on a high bluff overlooking Mississippi River and is surrounded with every adjunct for making a popular health resort. Two other artesian wells were sunk at Lagrange to a depth of 800 and 850 feet. Both obtained their flow from the St. Peter sandstone (First sandstone of Swallow). The water from these is mildly sulpho-saline and is largely shipped to Chicago and other points in Illinois. South of Lagrange, at Hannibal, in Marion County, two other flowing wells were struck at a depth of about 900 feet, the waters being also sulpho-saline, but neither is utilized commercially. Still farther south, at Louisiana, in Pike County, is another sulpho-saline artesian well, strongly impregnated with sulphureted hydrogen. This well is 1,350 feet deep and its flow is very strong. The log of the well has been lost, but it is believed that the main flow comes from the St. Peter sandstone (First sandstone of Swallow).

One of the most interesting wells in the State, and probably one of the oldest drill wells in the United States, is the Spaulding artesian well in the north part of Ralls County, 10 miles west of Hannibal. It was drilled by hand to a depth of 300 feet about 1823, by the Government, in search of brine for the manufacture of salt. The water is very strongly impregnated with salt and sulphureted hydrogen. The flow is very strong and has never perceptibly decreased. The source of the water is undoubtedly St. Peter sandstone (First sandstone of Swallow), as this horizon outcrops in greatly tilted beds a mile to the southeast. A hotel, lake, bath house, and pleasure grounds adjoin the well.

At Bowling Green, in Pike County, the B. B. springs carry 569 grains of mineral matter to the gallon, 475 grains of which are mag. nesium sulphate. The water is derived from Hannibal shales. Not far distant fron these are the Iris and Ionian springs, and the Kalinat well, owned by Mr. I. R. Stevens. The Kalinat water is somewhat similar to the B. B. water in composition, and probably has its source in the Hannibal shales.

This central district has already been referred to as the main artesian region in the State. Wells of this character are located at Huntsville, Randolph County; Salisbury and Brunswick, Chariton County; Carrollton, Carroll County; Sebree, Howard County; Sweet Springs and Malta Bend, Saline County, and Smithton, Pettis County. The Carrollton well is 241 feet deep. The principal flow of saline water was struck at a depth of 200 feet, at the base of the Cherokee shales. The Brunswick well, of sulpho-saline water, is 1,500 feet deep and was sunk at a cost of $\$ 1,500$. Its probable source is St. Peter sandstone (First sandstone of Swallow). A strong flow of very salt water was struck at 600 feet, probably in the Cherokee shales, but this was shut off by casing. The Salisbury artesian well, also sulpho-saline, was sunk by the city to a depth of 852 feet and at a cost of $\$ 2,500$. 
At Malta Bend, in Saline County, an artesian well was sunk to a depth of 1,250 feet. The first flow, strongly charged with salt and sulphureted hydrogen, was struck at 640 feet, in Cherokee (?) shales. At 840 feet a stronger flow of salt water was struck in sandstone (St. Peter sandstone?). At Sweet Springs a strong flow of sulpho-saline water, estimated at 840 gallons per minute, was struck in a well 1,074 feet deep. The cost of this well, $\$ 3,000$, was raised by subscription. Excepting a few chalybeate springs, the most notable springs in the central district are the Sweet and McAllister springs. A few years ago the former was a noted resort in the State, with a fine hotel and park. Since the burning of the hotel the property has depreciated, but the mildly saline water is still shipped from the bottling works. The McAllister springs are in a group located about 5 miles from Sweet Springs, the more important of them being the Black Sulphur and two salt springs situated in the old buffalo lick previously described. The conditions for well water are similar to those mentioned in the Lower Coal Measures of the eastern section.

In the western section of the North-Central Plain, on the western flanks of the Ozark dome, are two groups of artesian wells, one at Clinton, in Henry County, the other in Vernon County, at Nevada and Smithton. The writer is indebted to Dr. J. H. Britts, of Clinton, for records of the seven wells, five of them flowing, which were sunk at that place. Well No. 1 was sunk to a depth of 800 feet. At 425 feet a flow of 200 gallons per minute was obtained from the Moreau (Second) sandstone. At 800 feet a flow of 400 gallons was obtained from the Gunter sandstone (Third sandstone). Well No. 7, sunk to a depth of 818 feet, flowed 1,000,000 gallons daily, surpassing all the others combined. It derives its supply from the Gunter sandstone. This well, which yields a slightly alkaline sulphur water, furnishes an abundant supply for the city. Three of these wells are adjacent to one another, and their surplus waters form a beautiful lake, which, with a hotel and park, make a fine pleasure resort.

At Nevada, Vernon County, a well was sunk to a depth of 900 feet, at a cost of $\$ 2,500$. The principal water was reached at a depth of 550 feet, probably in the St. Peter sandstone. A beautiful park and lake surround this well. Another small artesian well is located at Smithton, in the same county.

The three beds of limestone of the Henrietta formation and some of the sandstone beds of the Cherokee shales are all water bearers and supply good waters.

OZARK-ST. FRANCIS DOME.

This is an area of decided uplift that extends from Missouri River to the Red in Arkansas, and from the Mississippi into Indian Territory. The rocks dip gently in every direction from the elongated 
axis. Erosion has cut deep valleys, especially on the eastern side. The two highest points are Taum Sauk, in the St. Francis Mountains, where an elevation of 1,800 feet is reached, and Cedar Gap, in Wright County, 1,700 feet above sea level. Structurally this area is somewhat complex, divergent anticlines merging into the main fold. There is strong evidence of two distinct periods of elevation. In the St. Francis Mountains the granites and porphyries are, it is believed, of Algonkian age. The major portion of the Ozarks are alternating beds of sandstones and dolomites belonging to the Silurian and Cambrian. Bordering these sandstones and dolomites are narrow belts of Devonian and Mississippian rocks. This is preeminently a district of great springs and caverns. In the St. Francis region, however, springs in the crystalline rocks are extremely rare. Considered geologically, the lowest water-bearing horizon, and the most prominent one in the State, is the Gasconade limestone (Third Magnesian). This has a maximum thickness of 500 feet, is frequently cavernous, and some of the largest springs in the country flow from it.

Mammoth Spring, in Arkansas, for example, just over the State line, with its source in Missouri, has a flow of 226,195,200 gallons per day. This is one of the largest springs in the world. Bennett's or Bryce's spring, in Dallas County, has a flow of 161,568,000 gallons per day. Ha Ha Tonka or Gunter's spring, in Camden County, has a flow of 158,982,000 gallons per day. Other immense springs are found in this formation. Greer Spring, in Oregon County, is reported by Prof. H. B. Shaw, of Missouri State University, in his paper on The Water Power of Missouri, published by the university press, to have a flow of 42,000 cubic feet per minute. Meramec Spring, in Phelps County, is reported by the same authority to have a flow of 7,500 cubic feet per minute. Double Spring, in Ozark County, the Waynesville and several other springs in Pulaski County, and a number in Miller, Crawford, and Morgan counties swell this record. As would be expected, great caves and enormous sink-holes abound, the latter marking the course of underground channels. The underground channel of the stream probably forming Mammoth Spring, in Howell County, is outlined by the "Grand Gulf," a wonderful sink threequarters of a mile long by 200 feet deep. From the bottom of this chasm a cave leads into a more recent channel, exposing the stream, which flows out as Mammoth Spring. The water from this formation is clear, cold, moderately hard, and carries from 10 to 15 grains per gallon-mainly lime and magnesian carbonates.

The Trenton limestone is a prominent water-carrier in Jefferson County. The "Big" or "House's" spring may be mentioned as an example from this horizon.

In the Delthyris shales, of the upper Silurian, springs are particularly abundant and in Perry County are often large.

IRR $114-05-15$ 
In the Chouteau group are found weak but highly mineralized springs. Next to the Gasconade limestone, the Burlington limestone is the most important water-bearing horizon in this area. Caves and large springs of remarkable purity, carrying from 15 to 20 grains of carbonates of lime and magnesia to the gallon, are found everywhere in the horizon, notably in Greene, Lawrence, Newton, McDonald, Barry, and Christian counties.

The St. Louis limestone, besides being cavernous, includes some large springs.

While only the more prominent water-bearing strata have been mentioned, it might be said that small but pure cold springs are numerous in all the formations of the Ozarks. A few chalybeate springs, issuing mainly from ferruginous sandstones, are found throughout the district. A few sulpho-chalybeate springs of considerable value issue from the Graydon sandstone of the Mississippian, notably those at Graydon and Eudora Springs, in Polk County, and at Paris Springs, in Lawrence County. Several cities in this district derive their water supply from large springs. Springfield, a city of 32,000 inhabitants, is supplied entirely from the Fulbright Spring, which issues from the Burlington. This remarkably pure spring carries only about 10 grains of mineral matter, mainly calcium carbonate, to the gallon.

A few small artesian wells are found in this district in McDonald, Newton, Christian, Camden, Miller, Cole, Jefferson, and Cape Girardeau counties. In St. Louis County is found a particularly interesting artesian basin, formed by Ordovician and Mississippian rocks dipping strongly underneath a patch of surface Coal Measures in the center.

\section{SOUTHEASTERN LOWLANDS.}

In this district the question of pure drinking water has been a serious problem. There are practically no springs. The country is low and frequently swampy, and the surface water contains considerable organic matter. The discovery of artesian water in a well sunk about one year ago at Campbell, Dunklin County, to a depth of 910 feet now points to an easy solution of this difficulty. The first flow of water in this well was reached at a depth of 135 feet, but the principal source was found at the bottom of the well. The water is soft and slightly charged with sulphur.

\section{COMMERCIAI SPRINGS.}

Besides being used as resorts or as adjuncts to sanitariums, 18 or more springs place the waters on the market. In 1902 these springs, a list of which is given below, reported shipments of 963,545 
gallons, valued at $\$ 204,270 .^{a}$ The water is used for table and medicinal purposes.
Akesion or Healing Spring, Sweet Springs, Saline County.
American Mineral Springs, St. Louis County.
B. B. Mineral Springs, Bowling Green, Pike County.
Blue Lick Springs, Blue Lick, Saline County.
Browns Lineville Springs, Mercer County, near Lineville, Iowa.
Eldorado Springs, Eldorado Springs, Cedar County.
Excelsior Springs, Excelsior Springs, Clay County.
Haymakers Lineville Springs, Mercer County, near Lineville, Iowa.
Jackson Lithia Spring, Jackson County.
Lineville Mineral Springs, Mercer County, near Lineville, Iowa.
McAllister Springs, McAllister, Saline County.
Magnesia Gusher Spring, Canton, Lewis County.
Monegaw Springs, Monegaw Springs, St. Clair County.
Mysterious Medical Spring, Canton, Lewis County.
Ponce de Leon Well, Desoto, Jefferson County.
Randolph Springs, Randolph Springs, Randolph County.
Sweet Springs, Sweet Springs, Saline County.
Windsor Spring, Windsor, St. Louis County.

\section{PRINCIPAL PUBLICATIONS.}

Mineral springs of the United States, by A. C. Peale: Bull. U. S. Geol. Survey No. 32 , pp. 164-170.

Preliminary list of deep borings in the United States, pt. 1, by N. H. Darton: WaterSupply and Irrig. Paper U. S. Geol. Survey No. 57, pp. 58-59.

Mineral waters of Missouri, by Paul Schweitzer: Missouri Geol. Survey, vol. 3, 1892. Missouri [well and spring records], by E. M. Shepard: Water-Supply and Irrig. Paper U. S. Geol. Survey No. 102, pp. 389-440.

Spring system of the Decaturville dome, Camden County, Mo., by E. M. Shepard:

Water-Supply and Irrig. Paper U. S. Geol. Survey No. 110, pp. 113-125. 


\section{IOWA.}

\section{By William Harmon Norton.}

The underground water resources of Iowa are of two classes. The first includes those bodies of ground water which are fed by the local rainfall and are reached by common wells, or issue as springs wherever the ground-water surface is reached by valleys. Artesian waters, the second class, comprise the more deeply circulating waters which move under pressure through permeable layers of the earth's crust.

\section{SHALLOW SUPPLIES.}

On account of the abundant rainfall of the State, there appears to be no considerable area where the waters of the first class are not found within easy drilling distance in quantities sufficient at least for domestic and farm uses. Their distribution, however, is governed by certain geologic conditions which will be briefly sketched.

\section{THE DRIFTLESS AREA.}

This area includes a relatively small tract in northeastern Iowa which was never covered by the various ice sheets which spread deposits of drift over the remainder of the State. Its maturely dissected surface has a greater relief than exists elsewhere in Iowa, having a maximum range of 600 feet. The ground water level lies low within the steep-sided and narrow ridges. The limestones which in part form the surface of these uplands are pitted with sinkholes through which the rainfall drains into cavernous passages and rapidly finds way to underlying massive and porous sandstones of great storage capacity, which supply copious springs wherever they are cut by the valleys.

\section{WATERS OF THE DRIFT.}

Outside the driftless area the State is covered with sheets of drift of various age. The most recent is the $W$ isconsin drift sheet, occupying the north-central portion of the State. It presents a surface with countless undrained depressions and streams which have hardly begun the work of erosion. Ground water here stands high, and exuding in the sags gives rise to the many lakelets and the extensive sloughs of the region. 
The Iowan drift sheet, which forms the surface in the northeastern portion of the State, has a topography that is somewhat older than

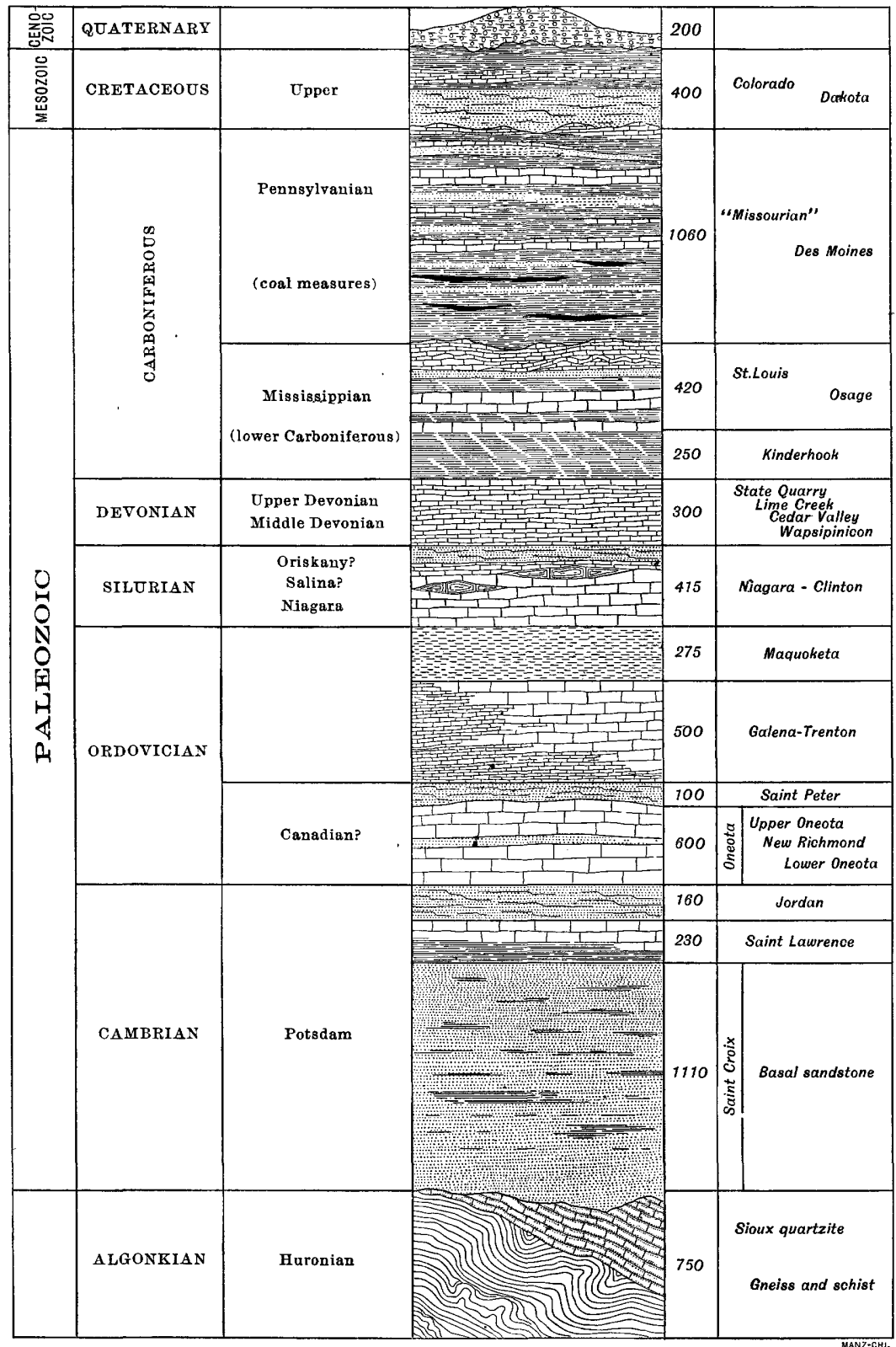

Fig. 34.-General geologic section of Iowa.

that of the Wisconsin, the lakelets and sloughs having been largely drained by the natural erosion of the streams. 
Except a narrow strip along Mississippi River, extending from Scott County southward, which was invaded from the east by the Illinoian ice, the remainder of the State is covered with the Kansan drift sheet, an old drift deeply weathered, and for the most part much cut by streams before the deposition of the surface silt known as "loess." Beneath the Kansan Iowa geologists have recognized still earlier drift, without surface outcrop, known as the "pre-Kansan."

Overlapping one another like the shingles on a roof, these broad sheets of stony clay, with their attendant beds of sand and gravel, largely control the distribution and the quality of the ground water of common wells. The stiff, stony clays of which the drift is chiefly composed are impervious and dry, water being found only in the seams of sand and gravel included within the mass of the drift sheet, and especially in the broad gravel and sand layers by which the successive sheets of drift are often separated, or which often immediately overlie the country rock. Thus the Buchanan gravel, a weathered and thoroughly oxidized deposit of Kansan age, is an important source of supply, even where lying beneath the stony clays of more recent ice invasions.

The drift is so thick and the distance to the various water-bearing layers so great that wells must frequently be sunk to depths of 100 feet or more. Except on special areas such as river plains, where ground water stands near the surface, the windmill is a marked feature of the typical Iowa landscape.

\section{ARTESIAN WATERS.}

The artesian field of Iowa is part of the extensive artesian area of the upper Mississippi Valley, which includes also a portion of Missouri, a large part of Illinois, and southern Minnesota and Wisconsin. The catchment area of the field lies for the most part in the two States last mentioned. From this gathering ground a succession of beds which supply all the requisite conditions for artesian wells slope southward. The series consists of many broad sheets of limestones, sometimes cavernous, of impervious shales, and of close-textured to porous sandstones, whose total thickness, as found by adding together the maximum thicknesses of the different formations, amounts to 6,000 feet. These strata, which include representatives of nearly all the stages of the Paleozoic system, and in western Iowa of some of the Mesozoic, rest on a floor of quartzites and schists of Algonkian age. In northern Iowa the strata also dip from the eastern and western boundaries of the State toward a median line, forming a shallow trough or syncline, whose axis lies in about the longitude of the upper Des Moines River. In southern Iowa the western limb of this syncline is depressed, and under the southwestern counties the rock sheets lie more nearly 


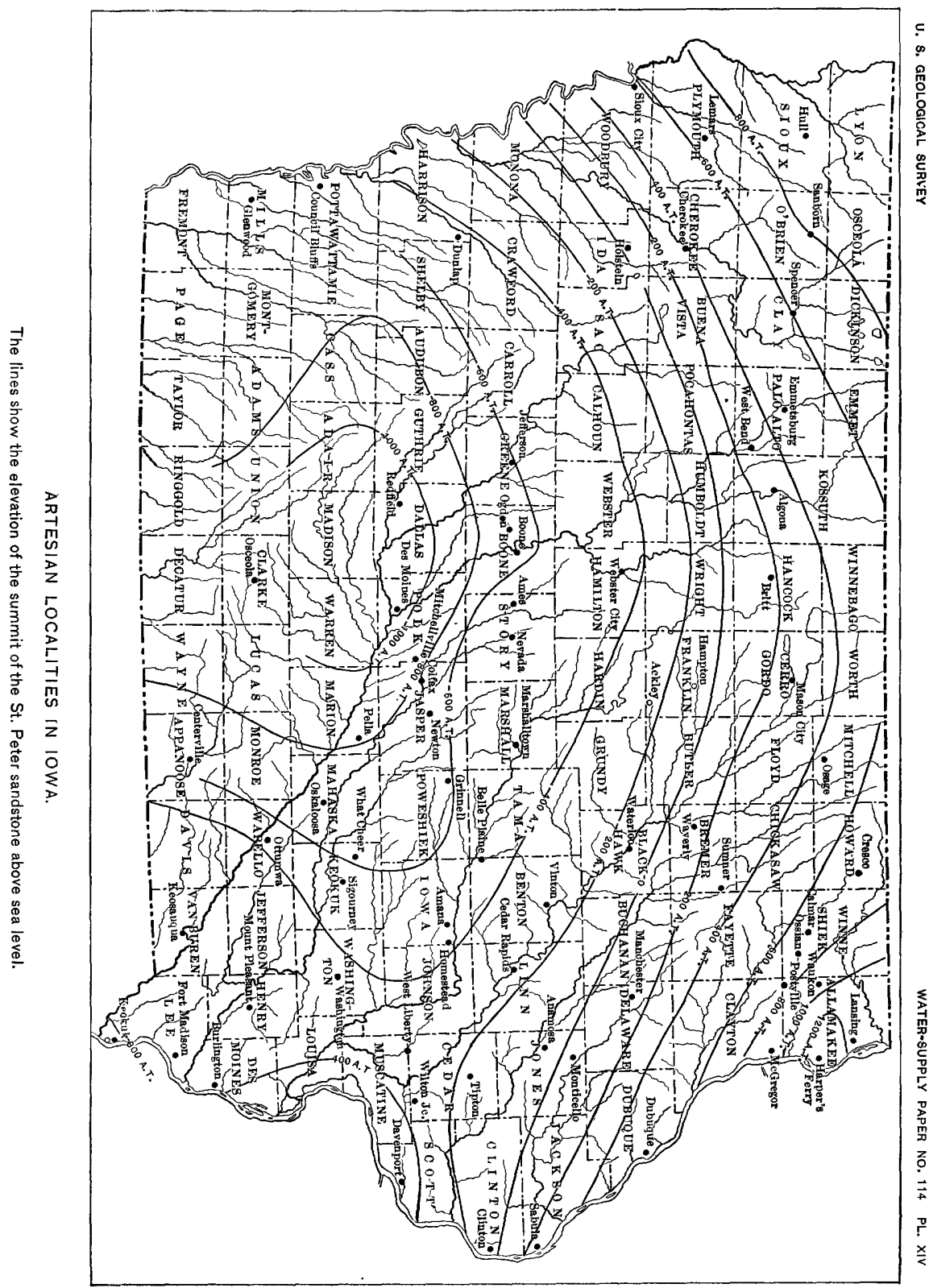


level. In southeastern Iowa the lower beds rise in a low dome now covered and concealed beneath later formations.

So exceedingly gentle are the dips of these strata that the catchment area is of great width, and the supply of the artesian reservoir correspondingly ample. Of perhaps still more importance is the consequence that even the basal water-bearing beds are within drilling distance over about four-fifths of the State. So far as known, their continuity is not interrupted by any fault or break barring the way of their percolating waters or presenting lines of leakage.

Cambrian rocks. - The lower division of the Cambrian may be called the St. Croix or basal sandstone. It rests directly on the Algonkian floor. It is at least 1,100 feet thick in the vicinity of the Mississippi River, but thins rapidly as it rises on the western side of the central syncline. All its pervious strata are water bearing, except where its summit lies above the ground-water surface along the Wisconsin border. Beyond the counties bordering the Mississippi in northeastern Iowa the nearly static waters of this deep reservoir are likely to be heavily mineralized. Thus at Cedar Rapids in a well that reached the Algonkian quartzite at 1,417 feet below sea level, the basal sandstone waters were so salty and so corrosive to the iron casing that the boring was plugged to shut off all water below that of the Jordan.

The most important water-bearing bed of the Iowa field is the Jordan sandstone, a light-colored, smooth-grained rock, from 100 to 200 feet thick. It is to this water-bearing stratum that drillers are usually encouraged to go, and it is here that they are often also urged to stop. The Jordan is separated by impervious shales and shaly dolomites, called the St. Lawrence, from the basal sandstone.

Ordovician, Silurian, and Devonian rocks.-At the base of the Ordovician is the Oneota (Lower Magnesian), a dolomitic formation, which may be divided into an upper and a lower division, separated by a bed of sandstone equivalent to the New Richmond of Wisconsin. With a thickness of from 300 to 600 feet, it appears to underlie the entire State, everywhere showing the perfect and complete dolomitization and admixture with arenaceous material characteristic of its outcrop. The flow of an artesian well is often notably increased as the drill penetrates this creviced and porous formation with its included sandy layers.

The St. Peter is a remarkably persistent formation whose normal thickness is about 100 feet. It is a bed of incoherent quartz sand, which, because of its freedom from clays and cementing material and because of the phenomenal roundness of its grains, is an exceptionally important water horizon. So distinct are its grains from those of any sandstone above it that the St. Peter is easily recognized by the experienced well driller as well as by the geologist. In northern Iowa, 
even as far west as Cherokee, it yields fair supplies of water derived from its outcrops in Minnesota.

Above the St. Peter is the Galena-Trenton, a body of limestone underlying considerable areas within the State. The Galena-Trenton is shaly at its base, and in places thoroughly dolomitized. The dolomitic phase, being porous and often creviced, occasionally yields artesian water, as at Davenport, the water apparently being derived from the underlying sandstone.

The Ordovician series includes as its highest member the Maquoketa shale, which has a maximum thickness of 275 feet, and which, in eastern lowa at least, effectively seals the formations beneath it. Where it lies near the surface and the Silurian (Niagara) limestone forms the country rock, it gives a water-tight floor, immediately above which water may often be obtained by ordinary wells in quantities sufficient for village supplies.

The Devonian and Silurian rocks are of slight importance except in southeastern Iowa, where the latter become arenaceous and yield a bountiful supply at Keokuk and Fort Madison.

Carboniferous rocks. - The importance of the Carboniferous system as a source of water supply is in part due to its wide extent west of Iowa River. Despite its great thickness-the lower or Mississippian division measuring 670 feet and the upper or Pennsylvanian division (Coal Measures) reaching a thickness of 1,060 feet-the permeable strata of the series are neither thick nor persistent. A number of flowing wells are, however, supplied from it, although their waters are often heavily mineralized and their discharge slight. The wellknown medicinal wells of Colfax furnish a typical example. In wells which reach the deep-lying beds beneath the Carboniferous, these upper waters, often impregnated with the sulphates of lime, soda, and magnesia, are not always effectively cased off.

Dakota sandstone.-The Dakota sandstone, which is a source of some importance in northwestern Iowa, is cut off from the great Dakota nield, where it carries an enormous volume of water under high head, by the mass of Sioux quartzite of southeastern South Dakota. In Iowa its water is under little head, and so far as tested is of poor quality.

Summary.-Successful artesian wells have been drilled in all parts of the State except on the high divides in southwestern Iowa, where the water-bearing rocks reach their greatest depth below the surface. More than 150 artesian wells-not counting those in glacial drift, which are numbered high in the hundreds-have already been drilled at an expenditure estimated at not less than $\$ 500,000$. The water supply of some of the larger cities of the State-such as Dubuque, Cedar Rapids, Clinton, and Boone-is drawn in considerable part from artesian wells, but is supplemented from other sources. In 
the cities the larger number of artesian wells are of private ownership, having been sunk by various manufacturing companies, such as packing establishments, breweries and bottling works, glucose works, and ice factories. In the number of artesian wells, Davenport heads the list with 14 or more. For smaller towns artesian water forms an ideal supply, and about 30 of such towns within the State have already availed themselves of it. Pure, unpolluted artesian waters are provided for a number of the State institutions, including the State College of Agriculture and Mechanic Arts, the two penitentiaries, two hospitals for the insane, and three of the minor institutions.

\section{MINERAI SPRINGS.}

Six of the springs of Iowa reported sales of their water for table or medicinal uses in 1902. They are as follows:

Boone Mineral Well, Boone, Boone County.

Colfax Mineral Spring, Colfax, Jasper County.

Fry's Colfax Mineral Springs, Colfax, Jasper County.

Lake View Medical Spring, Lake View, Sac County.

Ottumwa Mineral Springs, East Ottumwa, Wapello County.

White Sulphur Spring, near Davenport, Scott County.

The sales reached an aggregate of 152,050 gallons valued at $\$ 14,655,{ }^{a}$

\section{PRINCIPAI PUBLICATIONS.}

Mineral springs of the United States, by A. C. Peale: Bull. U. S. Geol. Survey No. 32, pp. 161-163.

Preliminary list of deep borings in the United States, pt. 1, by N. H. Darton: WaterSupply and Irrig. Paper U. S. Geol. Survey No. 57, pp. 39-41.

Artesian wells of Iowa, by W. H. Norton: Iowa Geol. Survey, vol. 6, 1897. 


\title{
MINNESOTA.
}

\author{
By C. W. HALL.
}

TOPOGRAPHY.

The topographic features of Minnesota are simple, and its relief is low. The highest point of the State-the Misquah Hills in the northeastern corner-is only 2,230 feet in altitude. The lowest point is the shore of Lake Superior at 602 feet. The average elevation is very close to 1,200 feet, since there are 42,390 square miles below and 41,897 square miles above the 1,200-foot level.

\section{WATER RESOURCES.}

\section{GENERAL CONDITIONS.}

The northeastern portion of the State seems so thoroughly well watered by streains, lakes, and springs that thus far there has been no strong demand for artesian water, and indeed the crystalline rocks lying immediately beneath the glacial drift offer an effectual bar to artesian boring. In the central portion of the State there is an occasional basin in which artesian waters gather and in which there are wells of moderate deptb. In these parts of the State much of the surface is too high to obtain flowing water, and is so high that only occasionally can supplies be obtained by pumping. Thus the southeastern and northwestern portions of the State are the only areas which may be regarded as artesian basins in any broad sense of that term.

Exploration for water in Minnesota during the last twenty-five years has shown that artesian waters are derived from a wide range of geological formations, which are grouped according to geologic age into Eo-Paleozoic, Cretaceous, and Glacial drift. There are few areas within the State where waters are not obtainable from at least one of these three groups, if they be obtained at all.

\section{WATER-BEARING STRATA.}

There are no water-bearing strata below the Paleozoic. Within the Cambrian and Ordovician rocks, which stretch in a widening belt from Duluth southward to the Iowa line, is a succession of sandstones alternating with shales, dolomites, and dolomitic limestones that yield copi- 
ous supplies of artesian waters. Comparatively little exploration has been done within this area from Duluth southward to Hinckley, the rocks being too thin and too high above the sea; but from Hinckley to the Iowa line scores of wells have been sunk, which, with very few exceptions, yield a supply of water.

Cambrian.-This series of dolomites, shales, and sandstones varies considerably, as shown by many exposures in the upper Mississippi region. In the St. Croix region is a series to which Dr. C. P. Berkey has given the name Basal sandstone. ${ }^{a}$ At the base of this series is a persistent sandstone, attaining a thickness of 1,000 feet at Minneapolis and gradually thinning out in all directions as though beneath this point was the deepest part of a great basin of deposition. So frequently has this bottommost sandstone layer been reached in artesian well boring, that its characters and those of the overlying rocks are thought to be pretty definitely established.

Above this sandstone is a bed of shales and dolomites of varying thickness and texture, which is called locally the St. Lawrence formation. Upon it rests another sandstone series called the Jordan, which locally attains a thickness of 116 feet. This is remarkably porous and is strongly water bearing, yet it is made up of unusually well-rounded and symmetrical grains, varying in coarseness from one-sixteenth of an inch down to granules of extreme fineness.

Ordovician. - Resting upon the Jordan sandstone is the Oneota formation, the most massive and uniform as well as the thickest bed of dolomite within the State. While the Oneota formation in many places is very porous through its dolomitization, it nowhere carries water sufficient to serve as a source of water supply.

Above the Oneota is a layer of sandstone called the New Richmond sandstone. Although this is a very thin layer, nowhere exceeding 20 feet in thickness and in places completely lost sight of by well borers, yet in a few localities it has become the source of a generous water supply. Upon this New Richmond sandstone, which appears to be the basal conglomerate of the Canadian series of the upper Mississippi Valley, rests a dolomite of somewhat unique characters, which for Minnesota has been named the Shakopee. This is of varying thickness and everywhere thoroughly dolomitized. It represents a formation much altered from its original condition. That it once was much thicker than at the present time there is every reason to believe. It sometimes carries small lenticular beds of sandstone, which in certain portions of the State appear as quite conspicuous features in the formation. Elsewhere their absence is a marked characteristic.

Resting upon the Shakopee with some unconformity, evidenced in part by the varying thickness of the Shakopee beneath, is a persistent sandstone called the St. Peter. This sandstone at Minneapolis and 
St. Paul is over 160 feet in thickness. Southward it thins to 75 or 80 feet, while at other points it becomes thicker. According to measurements in river valleys and artesian well borings its thickness is variable. This is an unusually strong water-bearing formation, and is utilized wherever it occurs as a source of water. To the north of Minneapolis, where the overlying rocks are removed and the St. Peter itself thinned by erosion, it yields water at varying depths, pumped by windmills for the use of the farm and the truck garden. The last of the Ordovician series in this part of the State is the TrentonGalena limestone. This has been so eroded by glacial wear that in places it is not more than 10 or 15 feet in thickness, but elsewhere, where protected from erosion, it attains a thickness of 200 or 300 feet. This rock contains no water, but when present serves as an effective cap in confining the waters of the underlying formations.

Cretaceous.-Less is known of the Cretaceous than of any series represented in the State. According to the records of wells, Cretaceous rocks come in from the Dakotas, where well-defined Cretaceous beds occur, and stretch over the divide of crystalline rocks and, in probably continuous beds of sandstones and shales, reach more than half across the State. Yet many portions of Minnesota, even in its western half, show no evidence of the existence of Cretaceons rocks between the glacial drift and the underlying pre-Cambrian rocks. The thickness of the Cretaceous varies and its altitude above the sea is far from uniform. The freedom with which water is obtained from this formation is a valuable factor.

Glacial drift.-This deposit is a remarkably persistent covering for all the older formations. In southeastern Minnesota for a few thousand square miles it is absent. Here the pre-Paleozoic rocks stand out at the surface as the prominent bed rock of the region. This area, named the driftless area by Chamberlin and Salisbury, is a part of the physiographic region embracing southwestern Wisconsin, northwestern Illinois, and northeastern Iowa. The glacial drift nearly everywhere carries water, the places where a sufficient supply can not be found being very few indeed. In thickness the deposits vary from 0 to 300 feet. Mr. Upham thinks that in the western half of the State they can not average more than 75 feet and in the eastern half they are 50 feet thick outside the so-called "driftless area" of the southeastern corner. The glacial drift affords waters through three distinct methods-artesian wells, shallow wells, and springs.

ARTESIAN BASINS.

The artesian basins of Minnesota may be briefly described as the (1) Southeastern artesian basin, (2) Red River Valley basin, and (3) small local basins.

Southeastern artesian basin.-This basin is within the area of the 
pre-Paleozoic rocks. Each one of the several sandstones in the series will yield water wherever it is present under the necessary conditions. The pre-Paleozoic rocks are in the form of a great arch or dome, the crest of which seems to lie in Rice, Goodhue, and Dakota counties. From this dome the Trenton limestone is worn away and the St. Peter sandstone has been subjected to erosion almost sufficient to sever its southern from its northern area. The lowermost of the sandstone

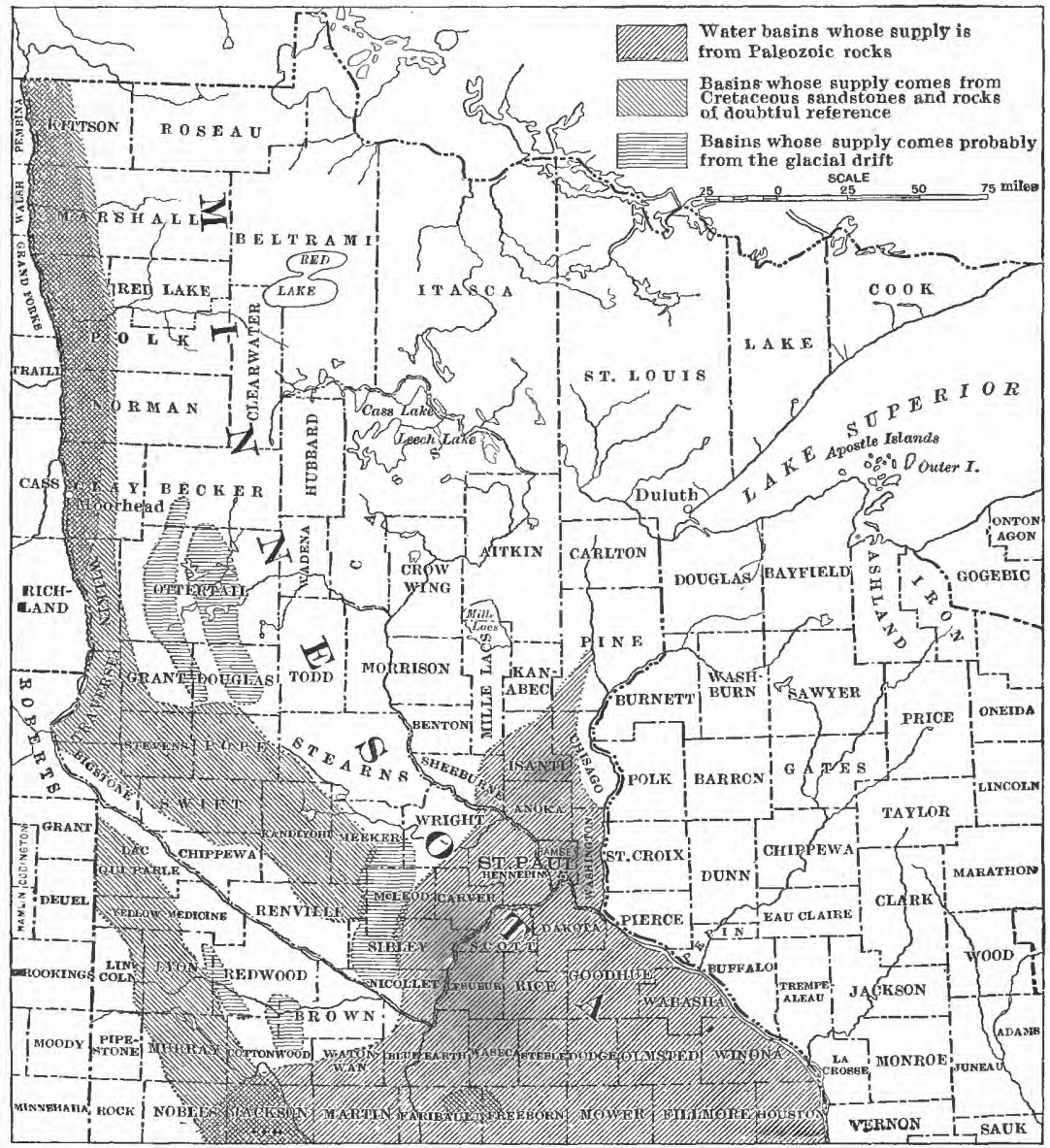

FIG 35.-Artesian basins of Minnesota.

series in this region seems to have a great thickening beneath Minneapolis and St. Paul. A well sunk in Lakewood Cemetery, Minneapolis (elevation 975 feet), disclosed granitic rocks 2,150 feet below the surface. Along the southern border of the State at Winona, Brownsville, and also La Crosse, Wis., granitic rocks were struck at about 525 feet below the level of the Mississippi, where the surface altitude was 625 feet. Since granitic rocks occur at St. Cloud at 1,200 
feet above sea level the basin-shaped nature of the bottom of this water-bearing district is clearly seen.

The Southeastern artesian basin lies within the portion of the State first settled. The population within this region is comparatively dense, being, it is estimated, about 100 per square mile. Several towns and many farmers get their principal water supply from artesian sources. It is estimated that 250 wells are now furnishing water within this area.

Red River Valley basin.-In Red River Valley all three of the great water-bearing series are drawn upon for artesian supplies. Comparatively few wells have been sunk to the Paleozoic rocks of northwestern Minnesota, but these few show that the Cambrian and Ordovician are water bearing. With exactly what formation in southeastern Minnesota Red River Valley sandstones can be correlated is impossible to determine with the data now available. The water is of fair quality, abundant quantity, and apparently permanent supply. The Humboldt well, the deep well at Moorhead, and a few others show the nature of the rocks and the quality of the water.

The second water-bearing beds are the Cretaceous sandstones. These are much more strongly developed in the southern end of the district than toward the north, and they show a very apparent tendency to thin out in passing eastward from the Red River and the Bois des Sioux River, which form the boundary between the Dakotas and Minnesota, toward the eastern border of the Red River basin. Indeed it is thought by some that the Dakota sandstone, the the remarkable water-bearing stratum of the James River basin, thins out and disappears before the Red River Valley is reached. Whatever the case, the sandstones which yield the water are uneven in texture, and of varying thickness and mineral composition. The number of wells within Red River basin in Minnesota drawing water from the Cretaceous sandstones is large. Mr. Warren Upham estimates ${ }^{a}$ that hundreds exist. Nearly every large farm in the valley has a deep, or artesian, well to supply farm buildings, gardens, and pastures. The surface water and the shallow well water are in many places so alkaline and so disagreeable to the taste that they can not be used successfully.

The third source of artesian waters is in the deeper layers of the glacial drift. Within the great plain of Red River Valley wells in the drift vary from 50 to 150 feet in depth, but in the moranic regions to the east of Lake Agassiz Plain a greater depth is frequently attained. The water from these wells is wholesome and is very generally utilized. 
By shallow wells is meant those wells from 10 to 100 feet in depth, sunk chiefly for domestic water supply. They are in general use among the farmers, and in the newer towns and villages there are large numbers of them. In older communities they are gradually being displaced by deep borings or, where conditions are favorable, by a supply from lakes or streams of recognized purity. Save in southeastern Minnesota these wells are almost invariably within the glacial drift. The water level in the drift follows so closely the general contour of the surface that there are few wells which do not yield a sufficient supply of wholesome water within shallow depths.

In the southeastern corner, within the so-called driftless area, shallow wells reach into the residual material derived from the alteration of the Paleozoic formations which occur in this portion of the State. The waters here are hard, but as a rule clear and wholesome. The water level is steadily sinking, so that farmers and others utilizing this supply are obliged to bore their wells deeper than formerly. Old wells must be deepened, and even then their supply is less than in former years. It is the general impression that the large demands for water from underground supplies exceed the inflow from the surrounding catchment areas, and thereby the diminution in quantity becomes a question of serious concern.

SPRINGS.

While springs occur throughout the State, there are certain structural conditions which locally prevent their formation. These are the stretches of modified drift and the glacial lake bottoms extended between the morainic belts characteristic of the topography of the State. There are not less than twelve of these moraines in the State. These belts of gravelly ridges and mounds are the source of supply of wholesome yet, in most areas, hard spring water.

There is no especial mode of occurrence noticeable in the distribution of springs. Their place of appearance depends upon the arrangement of the drift material through which or under which the water makes its way, beds of clay of greater or less extent being usually the determining factor. In the northeast portion of the State the conditions of occurrence are quite simple, since the waters gathered in the shallow glacial drift make their way out through the hollows worn by glaciation. In southeastern Minnesota springs occur along the river valleys and represent the completion of the underground circulation through the pre-Paleozoic rocks. The conditions of occurrence are determined by the depth of the river valley and the composition and texture of the rocks through which or between which the waters flow. 
The spring water of northeastern Minnesota seems to be softer than any other water in the State. Waters in southeastern Minnesota are, with scarcely an exception, hard. In the western part of the State the underground circulation is comparatively sluggish throughout the extent of the level tracts of glacial drift, which here carries a large proportion of fragments from calcareous shales and Mesozoic limestones. There are many alkaline springs as well as alkaline wells, and hardness is a universal characteristic of the water in this part of the State.

The following springs reported sales of water in 1902: ${ }^{a}$

Highland Spring, St. Paul, Ramsey County.

Indian Medical Spring, Elk River, Sherburne County.

Inglewood and Glenwood Springs, Minneapolis, Hennepin County.

Mankato Mineral Springs, near Mankato, Blue Earth Connty.

Trio Siloam Springs, Austin, Mower County.

The number of gallons sold is given as 2,217,000. The value was $\$ 415,140$.

\section{PRINCIPAL PUBLICATIONS.}

Mineral springs of the United States, by A. C. Peale: Bull. U. S. Geol. Survey No. 32, pp. 158-159.

Preliminary list of deep borings in the United States, pt. 1, by N. H. Darton: WaterSupply and Irrig. Paper U. S. Geol. Survey No. 57, pp. 55-57.

Minnesota [well records], by C. W. Hall and J. E. Todd: Water-Supply and Irrig. Paper U. S. Geol. Survey No. 102, pp. 441-488.

a Peale, A. C., Mineral Resources U. S. for 1902, U. S. Geol. Survey, 1904, p. 996. 


\title{
WISCONSIN DISTRICT.
}

\author{
By Alfred R. Schultz.
}

\section{LOCATION AND TOPOGRAPHY.}

Area included.-The Wisconsin district lies between Lake Superior and Lake Michigan, extending southward approximately to the parallel $41^{\circ} 30^{\prime}$, and comprising all of the State of Wisconsin, the Northern Peninsula of Michigan, and that portion of Illinois north of the Carboniferous deposits.

Topography.-In general the area is a broad plain, dipping toward the south. Portions of the area are rugged and rocky and broken by hills, which in the western part of Michigan rise to a height of 2,000 feet. North of a central elevation, which ranges between 1,500 and 2,000 feet, the remnants of a mass uplifted in early geologic times, there is an abrupt declivity which reaches to within a few miles

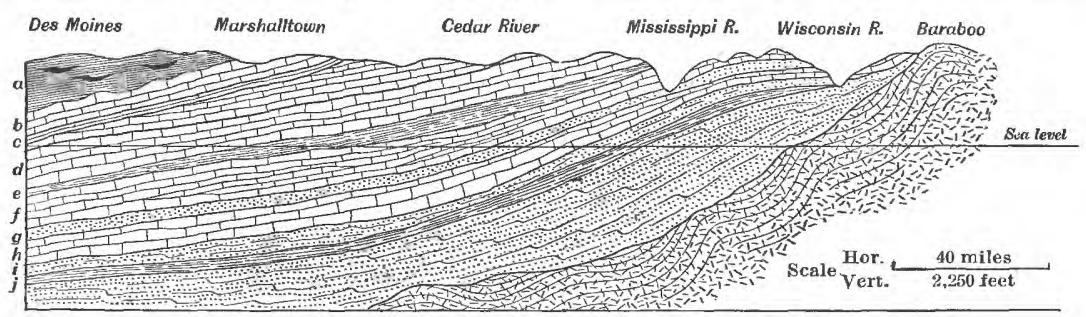

FIG. 36.-Geologic section from Baraboo, Wis., to Des Moines, Iowa. After Norton. $a$, Des Mcines; $b$, Mississippian; $c$, Kinderhook; $d$, Devonian-Silurian; $e$, Hudson beds; $f$, GalenaI'renton; $g$, St. Peter; $h$, Oneota; $i-j$, St. Croix, including Jordan, st. Lawrence, and Basal sandstone.

of the shore of Lake Superior, 622 feet above sea level. Across the entire northern portion of the area the divide is generally close to Lake Superior. It is lowest in the eastern half, where the Paleozoic rocks form the crest. South of the central elevation is a long slope, which in the southern part of the area is approximately 500 feet above sea level.

The central upheaval, together with two minor transverse swells, determined the chief drainage systems of the area and in a general way govern the circulation of the underground waters.

Among the minor topographic features are the elevations due to the Baraboo and Wausau quartzites, the Penokee-Gogebic and Marquette 
iron ranges in Michigan, and the sawtooth ridges of Keweenawan rock in the northwestern part of the district, all of which have affected the drainage and underground circulation. Extending from Green Bay, Wis., diagonally across the area to Rock Island, III., is a valley excavated in the soft, easily eroded Cincinnati shale. Its eastern boundary is a steep slope, composed of the resistant Niagara limestone. This valley is one of the most important of the district, many flowing wells being found within its borders. North of Green Bay the rivers, for the most part, cut directly across the underlying shale, but well borings show that the drift here is much deeper than over the Niagara limestone to the east, indicating the continuation of the ancient valley.

\section{GEOLOGY.}

Pre-Cambrian rocks. - The elevated central region of Wisconsin consists of pre-Cambrian granites, syenites, and schists, all having a very low crystalline texture and porosity.

North of the crystalline area are the Huronian deposits which form the Penokee-Grogebic iron range with its steep dip to the north, while on the northeast is the trough of the Marquette iron range. Rocks of the same age lie on the east, southeast, and on the southwest of the pre-Cambrian elevation, while small isolated outliers are found scattered over south-central Wisconsin.

The Keweenawan series, which overlies the Huronian, is confined to the northwestern portion of the area lying north of the Huronian of the Penokee-Grogebic iron range. The Keweenawan series extends from the most northern point of Keweenawan Point in a southwesterly direction across the district to St. Croix Falls, where it passes into Minnesota. The rocks lie in a synclinal trough whose axis bears northeast and southwest. In the northern half of the formation only the eastern portion of the trough remains, while the western portion probably lies beneath the surface of Lake Superior. The rocks consist of basic and acidic lavas, conglomerates, and sandstones, threefourths of which are igneous. The closing of the Keweenawan age also marks the end of volcanic activity within the area.

Potsdam sandstone.-Nearly surrounding these pre-Cambrian rocks, which carry very little water, is the Potsdam sandstone, which rests unconformably and horizontally upon the former. North of the crystalline rocks is a belt of sandstone of varying width bordering Lake Superior.

On the south the same formation extends in a crescent around the crystalline area, with its northeast prong joining the Iake Superior belt near Marquette, Mich., and its northwestern prong passing into Minnesota near St. Croix Falls, Wis.

The sandstone adjacent to Lake Superior in the western half of the 
area is of a red and brown color, well cemented and firm. Eastward the color becomes lighter and the eastern portion as well as that on the south is white or yellow, poorly cemented and unconsolidated, often crumbling in the band, while in some cases it is so hard that it might pass for a quartzite. The formation consists of fine calcareous sand, coarse siliceous sand, shales, marls, and layers of sand highly impregnated with iron oxide, thereby causing the water from some of the

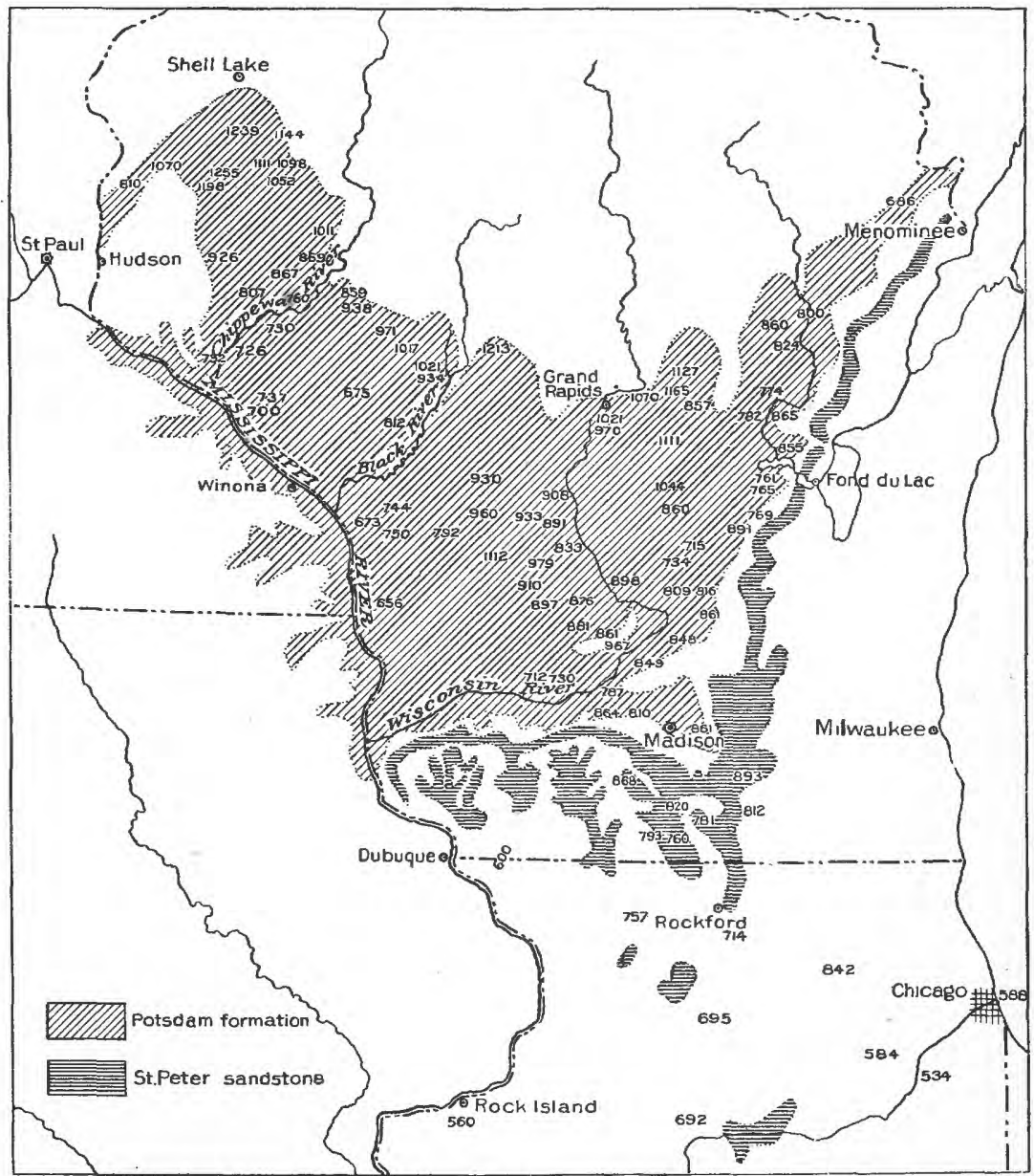

FIG. 37.-Wisconsin outcrop of Potsdam and St. Peter sandstones.

horizons to flow forth a blood red. The rock is very porous. Its grains are angular, and in some of the lower layers as coarse as No. 4 shot. The sandstone underlies the entire area to the east and south, dipping east, south, and west on the sides of the central elevation. Its thickness varies from nothing along the crystalline margin to 1,488 feet at Rockford, III. At Streator, III., it has a total thickness of more than 1,737 feet, showing a rapid increase toward the south. 
Lower Magnesian limestone.-Fringing the Potsdam sandstone on the south from the eastern part of Michigan to St. Croix River, in Polk County, Wis., is a narrow belt of Lower Magnesian limestone, varying in thickness from 50 to 200 feet. Along St. Croix and Mississippi rivers it caps many of the sandstone ridges. It is a dolomite, with considerable quantities of chert, crystalline quartz, and quartzose sand scattered through it near the middle of the formation.

St. Peter sandstone.-The St. Peter sandstone, which overlies the Lower Magnesian limestone, consists of a soft incoherent rock, of large well-rounded grains of quartz varying in color from white through yellow, pink, to a deep red. The formation is mapped in Michigan with the Lower Magnesian limestone and follows the eastern margin of that formation southward to the Illinois boundary, thence up the Mississippi to Vernon County, where it is all eroded. It reappears in Pierce and St. Croix counties. Isolated portions are also found farther south in Illinois, where erosion once more has brought it to the surface. The northern half of the eastern margin is considerably thinner, often being pinched out entirely, as shown by well records. The formation has a thickness varying from 0 to 250 feet in portions of Illinois.

Galena-Trenton limestone.-The Galena-Trenton limestone occupies a large surficial area extending from eastern Michigan southwest across the country to the Mississippi River, in Crawford County, Wis., and as far south as the southern boundary of the district. Small isolated patches are found capping the highest hills in Pierce and St. Croix counties in west-central Wisconsin.

The upper portion is a dolomite while the lower is more of a limestone. The various beds of this formation are often separated by shale. The rock contains many cracks and fissures which are partly filled with calcite, pyrite, marcasite, galena, and sphalerite. The combined thickness of the Galena-Trenton varies from 200 to 350 feet.

Cincinnati shale.-Overlying the Galena limestone is a formation composed largely of bluish to greenish shale with occasional thin bands of limestone. This shallow sea deposit is known as the Cincinnati shale and is one of the most impervious strata of the area. These soft shales are easily eroded and seldom exposed. They outcrop in a narrow belt seldom more than a few miles in width and close under the protecting Niagara limestone, extending from eastern Michigan southwestward to Rock Island, Ill., forming for the most part the Green Bay and Rock River basins. Another prong extends southeast from Lee County, Ill., around the Carboniferous deposits to the southern boundary of Ford County. A small area is found also in northwestern Illinois, along the Mississippi River. The thickness of the formation may be placed between 150 and 450 feet.

Niagarc limestone.-East of the Cincinnati shale occurs the Niagara 
limestone, which, in a few places, is separated from the shale by the Clinton iron-ore deposits. The Niagara deposit varies in thickness from 450 to 800 feet and extends from the eastern point of Michigan around the lake on its western shore, passing into Indiana southeast of Chicago. A small area is also found along the Mississippi River north of Rock River, capping many of the mounds in southwestern Wisconsin. The formation has a large surficial extent in the eastern part of the area. It is composed largely of calcium and magnesium carbonates and contains a large number of flints. Some portions are hard and cherty, while others are inclined to be sandy.

Later rocks.-Later deposits of rock within the area are of minor importance and occur over very small areas. In Milwaukee and Ozaukee counties in Wisconsin occur small deposits of the Lower Helderberg limestone, while in Milwaukee and St. Ignace, Mich., and south of Rock Island, IIl., occur remnants of a more extensive Devonian deposit.

Drift.--The entire area was overridden by glaciers, except a small part along Mississippi River, extending from Alma, W is., eastward to Grand Rapids, thence southward until it crosses the Mississippi again near Savanna, Ill., passing into Iowa. The ice sheet left a heterogeneous deposit of clay, sand, bowlders, etc., of varying thickness, burying and modifying the minor topographic features, and governing to a large extent the drainage and the occurrence of surface water throughout the greater portion of the area.

Lacustrine deposits. - Along the borders of Lakes Michigan and Superior are lacustrine deposits composed of alternating layers of red clay and beach sand. These deposits offer one of the cheapest and most satisfactory means of obtaining water for both farm and city purposes.

\section{WA'TER SUPPLIES.}

From the foregoing brief description of the topography, drainage, and geology of the district it may readily be understood that the source of water supply for the crystalline region, with the exception of some of the sandstone of the Keweenawan epoch and the sc.ter horizons of the Huronian, is restricted chiefly to the overlying bed of drift. This area as a whole has a very poorly developed drainage. The water table in most cases lies near the surface. Deep wells are seldom needed in this sparsely settled region. Cool, soft, and comparatively pure water may easily be obtained from the numerous springs, small streams, ponds, rivers, and lakes. Considerable difficulty, however, has been experienced in various places where a large quantity of water was required some distance from a lake or river; in such places the water-supply problem will take on a more and more serious aspect as the country becomes more thickly settled.

Potsdain sandstone.-The greatest of the rock water horizons of the 
area, and the one that universally furnishes a large supply of water, is the Potsdam sandstone, which nearly surrounds the crystalline rocks. To the south and east this formation is the great source of the artesian waters found scattered over the district. On the north a few records show that waters from its beds rise considerably above the level of Lake Superior. The impervious interbedded shales of this formation furnish ideal conditions for a good artesian supply at many places within the outcrop area itself. The shales, though not everywhere present, often give rise to several separate horizons of water-bearing rock. Wells of this nature may be found at Sparta, Whitehall, Durand, and numerous other places in $\mathrm{W}$ isconsin. Although the water from this formation does not reach the surface in many places, owing to the topography, it is always abundant, and may be depended upon as a supply for city purposes. On account of the adranced erosion and deep-cut valleys the entire Potsdam area west of Green Bay and north of Wisconsin River does not obtain any artesian water from beyond its own limits. Although water is abundant everywhere the artesian flows of this area are confined to the Mississippi Valley and its deeply eroded tributaries--St. Croix, Chippewa, Trempealeau, La Crosse, Wisconsin, Kickapoo, and Baraboo rivers--while on the east this artesian basin extends to Lake Michigan, and on the south it passes under the Carboniferous deposits. Whether artesian flows may be obtained depends largely upon the elevation above sea level.

Lower Magnesian limestone.-Along the eastern margin several water horizons are found above the Potsdam sandstone. Usually a sufficient supply for domestic use is obtained from the Lower Magnesian limestone, 50 to 100 feet from its top. In a few places this formation gives rise to flowing wells, which in some cases are caused by water from the Potsdam sandstone filling the cracks and fissures of the Lower Magnesian.

St. Peter sandstone.--The second greatest water horizon of the area is the St. Peter sandstone. Although of much less importance than the Potsdam, it furnishes an abundant supply of good water in the eastern and southeastern portions of the district. Northward it becomes of less importance, as it thins out and in many places pinches out entirely. In the southwestern part of the district artesian wells have generally not been obtained, as the rivers cut through well into this formation. However, in these parts the St. Peter sandstone always gives an abundant supply of water for domestic uses.

Galena-Trenton limestone.-The Galena-Trenton limestone, like the Lower Magnesian limestone, yields, in most cases, sufficient water for domestic use. It is seldom necessary to sink the wells more than 100 or 150 feet, and in some cases a sufficient supply for small cities has been obtained at 75 feet. In some localities, notably north of Green Bay, this formation gives rise to flowing wells. In some cases it 
appears that the water of this formation is obtained from the underlying St. Peter sandstone, the overlying Niagara limestone, etc.

Niagira limestone.-The Niagara limestone, although hard, compact, and in places highly impervious, furmshes a copious supply. Water is usually obtained from fissures, joint planes, or crevices at a depth considerably less than 200 feet. The formation furnishes requisite artesian conditions, and in a great many instances, particularly along the eastern half of its extent, between Manitowoc and Milwaukee, many fine flows are obtained.

Along the eastern margin of the district the artesian flows are confined to the vicinity of Lake Michigan and to a strip on each side of all the valleys. In the Green Bay and Rock River basins are many of the flowing wells of the interior. The rapid weathering of the impervious Cincinnati shale has reduced this part of the area to such a level that artesian waters might rise to the surface.

Lake deposits.-Besides these deeper-seated waters and the waters coming from the lacustrine deposits along the shores of Lake Michigan and Lake Superior, the area is well supplied with shallow underground waters, commonly known as surface water. Surface wells are found by the score all over the drift area and vary in depths from 10 to 80 feet, and in some case, as along the Kettle Range in eastern Wisconsin, reach a depth of 300 to 400 feet. Many of these wells are not free from contamination, and during the last few years many have gone dry. In 1903, however, nearly all the wells formerly dry had a good supply of water. Along some of the larger streans water is obtained from the river-washed sand and gravel by sinking wells from io to 40 feet. Many of these are open or drive wells.

\section{SPRINGS.}

Along both sides of the Kettle moraine glacial drift is the source of many fine surface springs and also of subteiranean springs that feed so many of the small lakes. Other strong springs from the drift are scattered over the district. In the northwestern part of the area these strong springs flow from the drift orerlying the trap rock, and in many cases the water gushes forth in a small stream several feet wide and over a foot deep. So strong are some of these that they have been utilized for water power, as at St. Croix Falls, where a 35-horsepower mill is operated by the water from a spring. Springs have their source in the upper surface of the Cincinnati shale along the east ridge of the Green Bay and Rock River valleys or along the contact of the Niagara limestone and the Cincinnati shale. The impervious shale stops the descending waters flowing through the fissured Niagara limestone, and it escapes at the first opportunity, producing inni:merable springs, both great and small, along the entire extent of this marked and important contact. Much of the water from this 
source never comes to the surface near the contact but flows underground through the sand and gravel beneath the red clay and gives rise to some of the fountains found east of Fond du Lac. The other important horizons are confined chiefly to the contact of the Potsdam sandstone and Lower Magnesian limestone and to the contact of the Galena-Trenton limestone and the St. Peter sandstone. In many cases in western Wisconsin springs also arise from various horizons of the Potsdam sandstone.

\section{MINERAL WATERS.}

Along the eastern margin a considerable number of strong springs flow from the Niagara limestone, of which the most noted are the famous Waukesha Springs, whose waters have long been on the market. Although considerable water is being bottled, this industry is still in its infancy and waiting for development. At present there are innumerable springs moderately charged with mineral matter and well adapted for certain medical uses, whose waters have never been analyzed. Most of the springs within the area contain a small amount of mineral matter averaging approximately 300 parts per $1,000,000$. Other springs of a much higher degree of purity are found, one containing only a little over two grains per gallon, three-fourths of which was in the form of carbonates. Most of the springs thus far have received but little attention outside their use for domestic purposes. In some cases springs have been and are being used for public water supples, as at Lancaster, Wis., where a spring with a daily capacity of 2,160,000 gallons furnishes the entire city with wholesome water. The deeper seated waters are used chiefly for city water supply and for various manufacturing industries.

In a few cases where the waters have rare medical properties, as at Sheboygan and Prairie du Chien, Wis., the waters have been bottled and placed on the market or used for special treatment at the sanitarium. The amount of mineral matter contained in the well water for the most part is comparatively small, in some cases being as low as 7 grains per gallon and seldom being more than 50 grains per gallon. However, in a few cases the amount exceeds 600 grains per gallon, while at Osceola, on Silver Brook farm, the water from the Potsdam sandstone at a depth of 50 feet contained a total of 993.9 grains per gallon, made up as follows: $\mathrm{NaCl}, 320.58$ grains; $\mathrm{CaCl}_{2}, 583.1$ grains; $\mathrm{MgCl}_{2}, 18.98$ grains; $\mathrm{CaSO}_{4}, 62.20$ grains; iron and aluminum oxides, 2.97 grains, and silica, 6.07 grains. Concerning this water, which has recently been analyzed, J. H. Long writes as follows:

This water is a very unusual and peculiar one because of the presence of so large an amount of calcium chloride. I do not recall any mineral spring in this country which resembles it in this respect, but some of the so-called bitter springs of Germany have a somewhat analogous nature. The water is too highly charged with mineral matters to be used in quantity as a medical beverage, but in special cases and for a limited time it might be profitably used. Such waters are often used for 
baths; in fact, that is their main application, and medical men could suggest the cases in which such a water as this one could be used properly.

There is no doubt that in the future these various fields will be greatly extended and many of the cities now without a system of waterworks will soon draw upon the underground channels for their supply.

A list of the springs which reported sales of mineral water in 1902 is given below: ${ }^{a}$

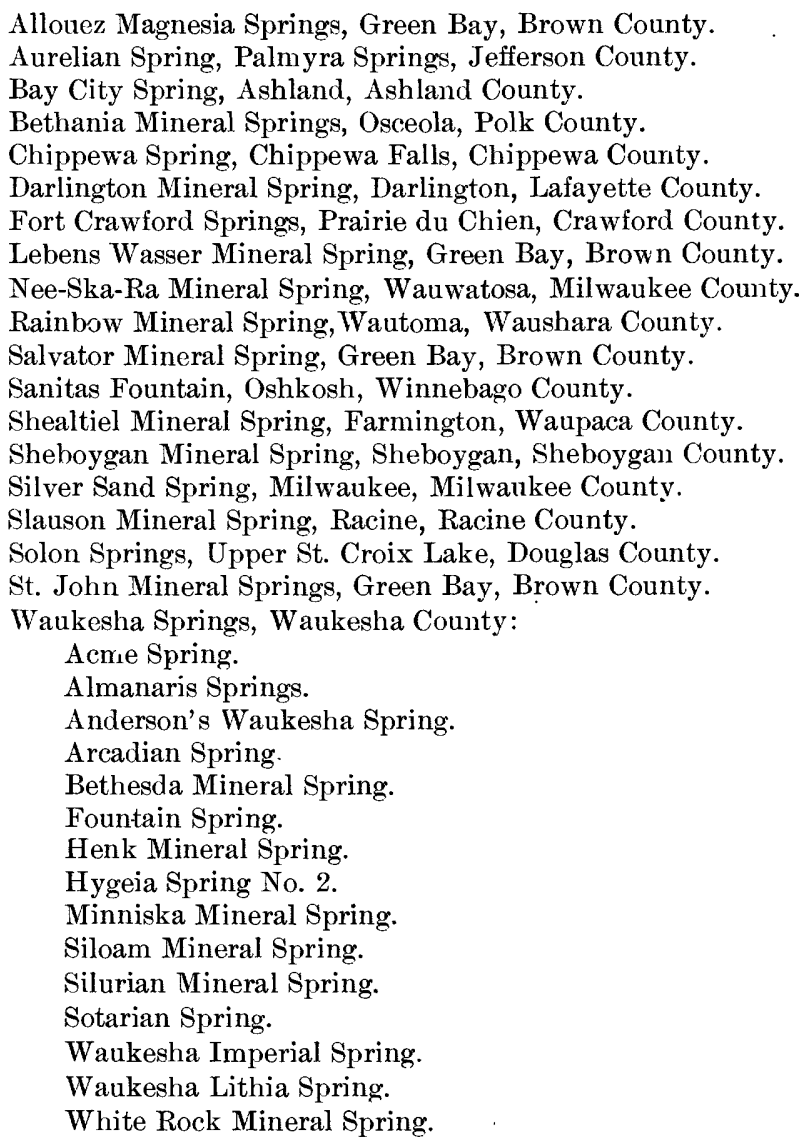

The reported sales reached a total of 5,982,948 gallons, with a value of $\$ 1,199,473$.

\section{PRINCIPAL PUBLICATIONS.}

Artesian wells, by T. C. Chamberlin: Wisconsin Geol. Survey, 1873-1879, vol. 1, pp. 689-701, 1883.

Mineral springs of the United States, by A. C. Peale: Bull. U. S. Geol. Survey No. 32, pp. 151-157.

Preliminary list of deep borings in the United States, pt. 2, by N. H. Darton: WaterSupply and Irrig. Paper U. S. Geol. Survey No. 61, pp. 65-66. 


\section{LOWER MICHIGAN. ${ }^{a}$}

\section{TOPOGRAPIIY.}

Lower Michigan is mainly a rolling area, with an elevation ranging generally between 600 and 1,000 feet above sea level. In the southern half of the peninsula the general level is broken by relatively low morainal ridges left by the glaciers which once covered the region. In the northern portion of the State the morainal deposits are much more pronounced, occurring as prominent northeast-southwest ridges, and in places rising to heights of over 1,500 feet. The topographic features are, in fact, due almost entirely in most areas to the accumulation of glacial drift, which may reach a thickness of 800 feet or more, and completely buries the irregularities of the underlying rock.

\section{GEOLOGY.}

Leaving out of account the glacial drift which has been mentioned above, and considering only the consolidated rocks, the Lower Peninsula of Michigan is structurally a great oval basin, toward which the rocks dip from all sides. The geographic center is in Gratiot County, about 50 miles north of Lansing. The strata are mainly of Carboniferous age, but a rim of Devonian rocks extends along the shores of Lakes Michigan and Huron from Mason County, on Lake Michigan, to Alpena County, on Lake Huron. Small areas or strips of Devonian rocks occur along the rim of the coal basin, in the extreme southeastern and southwestern portions of the State. A few dolomitic and other beds of Silurian age also occur at the extreme northern tip of the peninsula and along the shores of Lake Erie to the southeast.

The general character of the basin and the outcrop of its beds is shown in fig. 38 , while fig. 39 shows a cross section of the basin from west to east.

\section{UNDERGROUND WATER SUPPLIES.}

SUPPLIES OF THE DRIFT.

Eastern shore district. - -This district embraces the eastward-sloping strip lying between the moraines and the shores of Lakes Huron, St. Clair, and Erie, from Saginaw Bay to the southern limits of the State.

The surface deposits of the region, except in some of the valleys

$\alpha$ Compiled mainly from report by A. C. Lane on Water Resources of the Lower Peninsula of Michi. gan, Water-Supply and Irrigation Paper U. S. Geol. Survey No. 30, 1899. For facts relating to the Upper Peninsula of Michigan, see the description of the Wisconsin distriet, pp. 233 to 241. 
and in the old beaches along the lakes, are predominantly clay. The clays yield no water, but small supplies, which are liable to fail in times of drought, are found in pockets of gravel or sand in the clay, and a water-bearing layer commonly occurs at the contact of the drift with the underlying rock. Near the moraine the water-bearing sands

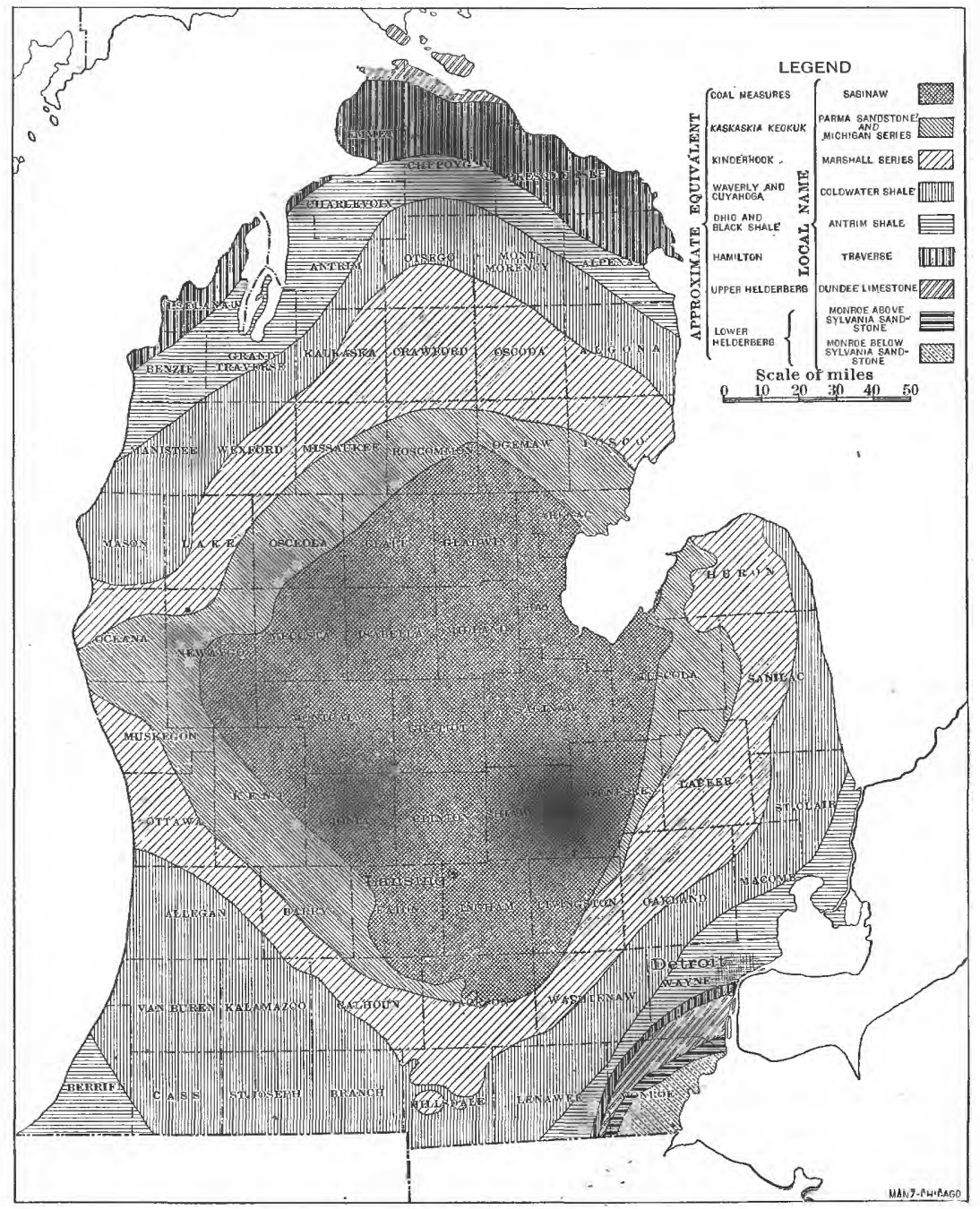

FIG. 38.-Geologic sketch map of lower Michigan.

are more numerous, and at least one city, Ypsilanti, obtains its public supply from wells in the drift. The waters in the upper part of the drift are of good quality, but in the lower part they are of ten charged with salt and other minerals, or with gas derived from the underlying rocks from which the waters come. Some of the wells flow. In the stream and other gravels and sands of the valleys and in the sandy 
beaches bordering the lakes good waters are often obtained by shallow wells, but the wells are liable to fail in especially dry seasons.

Saginaw Valley district.-This distrist includes the drainage basin of Saginaw River and portions of adjacent regions. The surface is flat, the streams generally flowing in shallow valleys. It is covered with clayey drift or hardpan, or with clays deposited in a glacial lake, the deposits averaging from 80 to 100 feet. Sand ridges occur near the lake.

The sand ridges carry water in moderate amount and subject to contamination. Sands and quicksands within the clay frequently yield somewhat hard water, which may even flow. The wells are easily clogged. Water equally good and with a greater head can be obtained by drilling into the underlying sandstones. Some of the drift wells

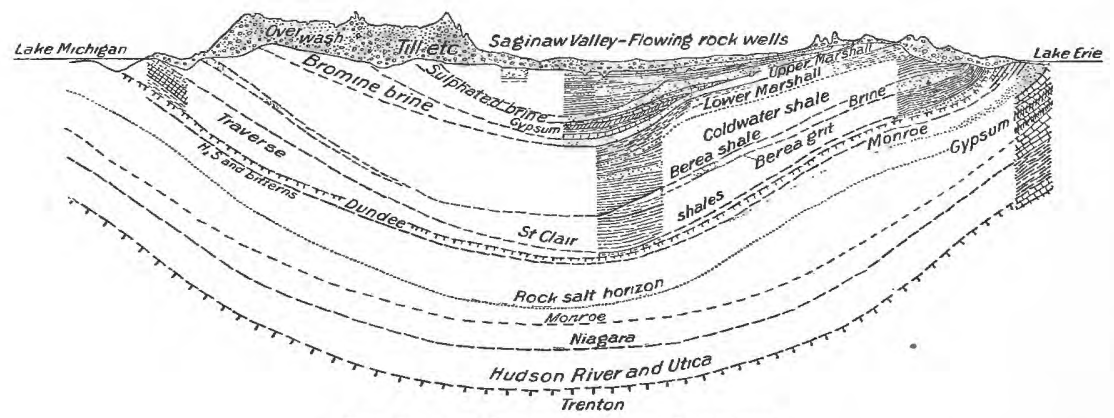

FIG. 39.--Section across lower Michigan.

carry calcium sulphate derived from gypsum in the drift, and gas is not uncommon.

Northeastern shore district.-This area embraces the drainage area of the Thunder Bay River and a few small streams emptying into the lake in its vicinity. To the southwest lies a high moraine containing some of the highest land in the State. The surface consists of a series of morainal ridges with intervening tracts covered by sand. Water can be obtained from this sand, though it frequently lies at a considerable depth. Springs emerge where the clay layers are cut by streams. Deep wells in the drift find sands with water, which will sometimes rise to the surface from beneath till and clays. The water is quite hard, but is otherwise generally excellent. It is hardly suitable for use in boilers.

Western shore district.-This district lies along the northwest and west coast of the peninsula, and extends inland far enough to include a portion of the high morainal ridges. The surface is drift, the rocks frequently lying from 500 to 600 feet below the surface. The drift is generally clayey, but contains many beds of sand, some of which can be reached by driven wells. Sometimes, in the more porous drift, wells 
Wm. A. Lamb.

must be sunk 300 to 400 feet to obtain water. The waters are seldom saline.

North-central district.-This area includes the upper portions of the drainage basins of Manistee, Muskegon, and Au Sable rivers and adjacent areas. The surface consists mainly of sandy drift, yielding water to shallow driven wells. In the few deep wells that have been sunk, the thickness of the drift is found to be 350 to 500 feet, or more.

Saginaw moraine district.--This area includes the region of the Saginaw moraines in the central part of the State, and southwest of the Saginaw Valley district. The region is one of morainal drift, the deposits being generally from 100 to 500 feet thick. The composition of the drift is very variable, and many water-bearing sands occur. The underlying rock furnishes a reliable source of water, and a few wells have been drilled into it. Wells some times flow in the lower districts.

South-central district.-This district includes the land in the central portion of the State lying south of the Saginaw district. The drift is usually thick. The water conditions are much the same as in the Saginaw district.

ROCK WATERS.

Trenton limestone. - This limestone has been penetrated at Monroe, Wyandotte, Dundee, Blissfield, and Dowagiac. It yields a strong, but impure brine, with traces of oil and gas.

IIudson and Utica shales.-These shales have been penetrated by a few wells drilled to the Trenton limestone. They are similar to the Coldwater and St. Clair shales.

Niagara and Clinton linestones.-These are penetrated only in southeastern Monroe County, southwest of Kalamazoo and north of Frankfort. Water was obtained from these beds at Dundee and Britton, but they are otherwise undeveloped.

Monroe and Salina beds.-These beds are mainly buff marls, dolomites, and rock salt, but at the top there is a persistent sandy bed yielding much water. The waters are mainly brines, but fresh water has been found in one or two horizons near the outcrop.

Dundee limestone.-This is a light limestone full of tlint and carries considerable quantities of water charged with salt, hydrogen sulphide, and other minerals, making it the source of some of the most valuable mineral water of the State.

Traverse series. - This series consists of alternations of limestones and shales with an aggregate thickness of 500 feet or more. In the northern part of the State the series yields water freely in some cases, and even in the southern part water is obtained from several of the limestones.

Antrim shales.-These are blue to black shales underlying the Berea grit. They yield neither fresh water nor brines in any amounts. 
Berea shale and grit. - Below the Coldwater shales lies about 130 feet of black or chocolate shales, while beneath these in turn is about 60 feet of white to brown sandstone yielding at any considerable depth pure brines with some gas.

Coldwater shales.-These shales are generally fine grained, micaceous, and bluish. They carry little water, but small amounts are obtained from sandy layers in a few wells.

Lower Marshall sandstone.-This formation is about 260 feet in thickness and consists of ferruginous, sandstones, flags, etc., underlying the Upper Mar'shall sandstone. It yields good water, rather chalybeate.

Napoleon or Upper Marshall sandstone.-This sandstone, which belongs to the Carboniferous system, is rarely less than 50 feet thick, and underlies the drift in a broad belt extending from Saginaw Bay southwest to the southern boundary of the State in Hillsdale County. It yields copious supplies of fresh water through many flowing wells that have been sunk to a depth of about 250 feet through the western part of Huron County to Sebewaing. Wells sunk to greater depths, if the rocks of the Michigan series are not properly cased off, yield salt water. Southwest of Lansing and Mason the water is generally good.

Michigan series.--This series consists of shales, hydraulic limestones, and gypsum beds immediately overlying the Upper Marshall sandstone. The waters are almost universally salt or bitter, and must be carefully cased off in all wells going to a deeper horizon for fresh waters. This series can be traced beneath the drift by the composition of the water. Included in the Michigan series is the Grand Rapids limestone.

Parma sandstone. - The Parma sandstone unconformably overlies the Michigan series and is generally separated from the Marshall by a thin bed of shales, but in places merges with it. The waters of both the sandstone and limestone are generally hard, though in some cases they are pure. They have seldom been used for brines.

Overlying the Parma is a series of shales, sandstones, coal, fine clays, iron ores, etc., yielding much water of a highly mineralized character and frequently of medicinal value. Wells are very numerous throughout the region.

\section{MINERAL SPRINGS.}

The following 28 springs reported sales in 1902, amounting to $8,653,690$ gallons, with a value of $\$ 275,763 .{ }^{a}$

Alma-Bromo Spring, Alma, Gratiot County.

Andrews Magnetic Mineral Springs, St. Louis, Gratiot County.

Bromo-Hygeia Mineral Well, Coldwater, Branch County.

Clementine Spring, Mount Clemens, Macomb County.

Cooper Farm Spring, Birmingham, Oakland County.

Eastman Mineral Springs, Benton Harbor, Berrien County.

El Cajon Mineral Springs, El Cajon Beach, Alpena County. 
Frankfort Springs, Frankfort, Benzie County.

Magnetic Mineral Spring, Spring Lake, Ottawa County.

Midland Mineral Springs, Midland City, Midland County.

Moorman Springs,.Ypsilanti, Washtenaw County.

Mount Clemens Sprudel Water, Mount Clemens, Macomb County.

No-che-mo Mineral Spring, Reed City, Osceola County.

Original Mount Clemens Mineral Spring, Mount Clemens, Macomb County.

Pagoda Spring, Mount Clemens, Macomb County.

Plymouth Rock Well, Plymouth, Wayne County.

Ponce de Leon Springs, Paris Township, Kent County.

Premier (formerly Excelsior) Mineral Springs, Benton Harbor, Berrien County.

Prosit Flowing Well, Oak Grove, Flint, Genesee County.

Red Cross Mineral Well, Big Rapids, Mecosta County.

Royal Oak Mineral Springs, Royal Oak, Oakland County.

Salutaris Spring, St. Clair Springs, St. Clair County.

Sanator, formerly Americanus Well, Lansing, Ingham County.

Sterling Spring, Crystal Falls, Iron County.

Victory Springs, Mount Clemens, Macomb County.

Welcome Island Lithia Springs, near Pontiac, Oakland County.

Wurtzel's Mineral Spring, Thomastown, near Frost, Saginaw County.

Zauber Wasser Springs, Hudson, Lenawee County.

\section{PRINCIPAL PUBLICATIONS.}

Mineral springs of the United States, by A. C. Peale: Bull. U. S. Geol. Survey No. 32, pp. $145-150$.

Water resources of the Lower Peninsula of Michigan, by A. C. Lane: Water-Supply and Irrig. Paper U. S. Geol. Survey No. 30, 1899.

Lower Michigan mineral waters, by A. C. Lane: Water-Supply and Irrig. Paper U. S. Geol. Survey No. 31, 1889.

Preliminary list of deep borings in the United States, pt. 1, by N. H. Darton: WaterSupply and Irrig. Paper U. S. Geol. Survey No. 57, pp. 51-54.

Michigan [well records], by W. F. Cooper: Water-Supply and Irrig. Paper U. S. Geol. Survey No. 102, pp. 489-512.

IRR $114-05-17$ 


\section{ILLINOIS.}

\section{By Frank Leverett.}

\section{INTRODUCTORY STATEMEN'T.}

This brief discussion of water conditions in Illinois is restricted chiefly to the relative value of the several geologic formations as water-bearers. Several other topics relating to water conditions, namely, rainfall, drainage basins, run-off and regimen of streams, navigation, water power, city, village, and rural water supply, artesian wells, and water analyses have been discussed by the author in some detail in earlier reports of this Survey. ${ }^{a}$ A chemical survey of the water supplies of Illinois is the topic of a report of 98 pages by Dr. A. W. Palmer, issued by the University of Illinois in 1897, and a later report of 254 pages by the same author giving the results of several thousand analyses has been issued by the University within the last year.

\section{GEOLOGIC COLUMN.}

The rock formations either exposed or within reach of the wells of Illinois extend through the Paleozoic series from the Cambrian to the later part of the Carboniferous, including perhaps the Permian, as indicated in the table on page 249 . There is then a wide gap, the next formation being the Cretaceous, which has been found to underlie the Ohio River at Cairo, but is not known to be exposed in the State. ${ }^{b}$ On the borders of the Ohio in southern Illinois are deposits of Tertiary age, consisting mainly of clay, micaceous sand, and a ferruginous, pebbly conglomerate. These deposits are probably separated from the Cretaceous by an interval of some consequence, and are known to be separated from the next later formation developed in Illinois, the Pleistocene, by a wide interval. In the table on page 249 the several drift sheets of the Pleistocene are presented because these divisions of the drift are of importance in discussing the water conditions. They should not, however, be given the rank of the divisions in the Paleozoic series. The table begins with the newest formation and extends to the oldest,

$a$ Water resources of Illinois, Seventeenth Ann. Rept. U. S. Geol. Survey, pt. 2, 1896, pp. 695-849. The Illinois Glacial lobe, Mon. U.S. Geol. Survey, vol. 38, 1899, 817 pp.

b Nickles, J. M., Report of Illinois Board of World's Fair Commissioners, p. 217, Springfield, 1895. H. W. Rokker, State printer. 


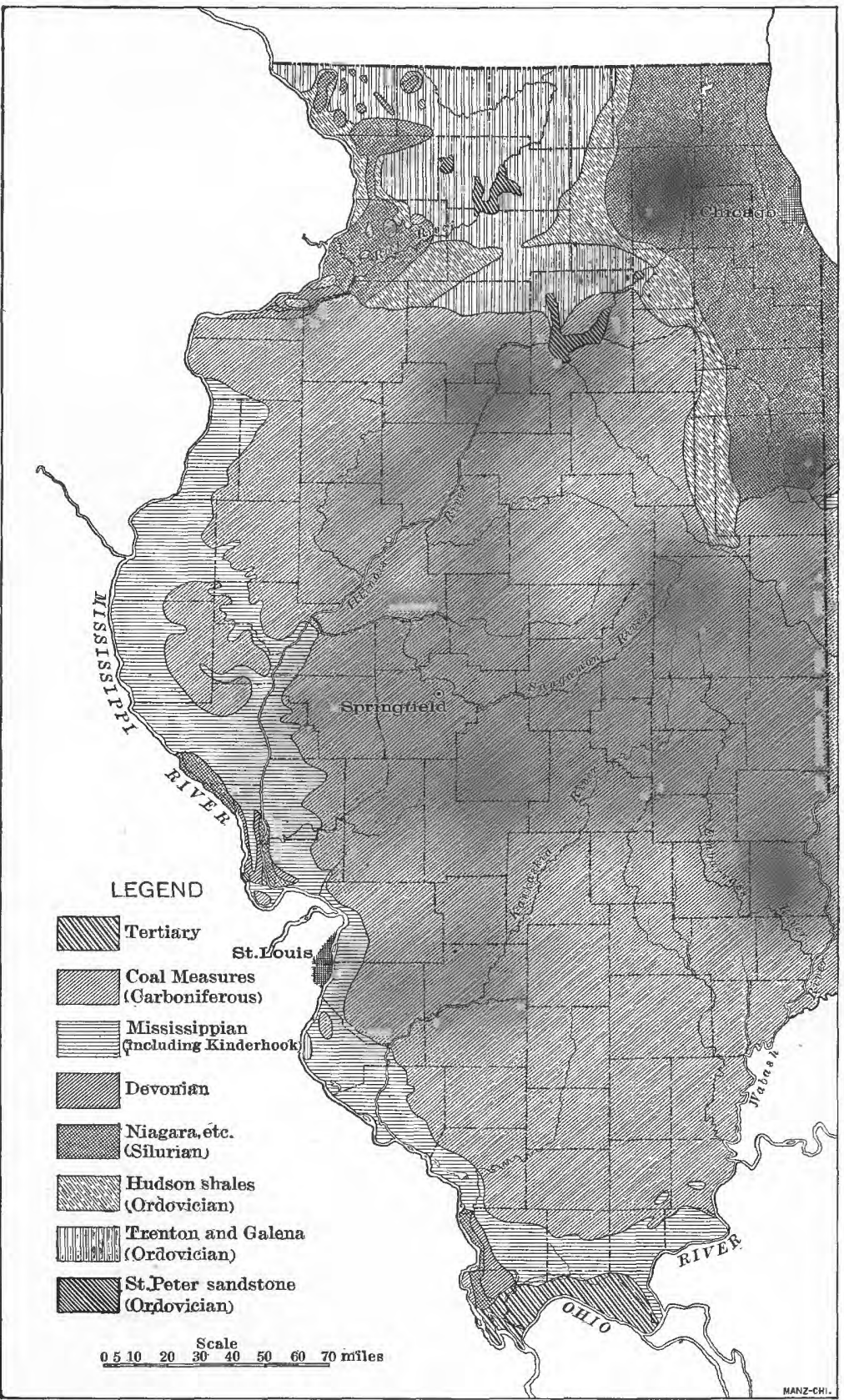

GEOLOGIC SKETCH MAP OF ILLINOIS. 
this being the order in which they are met by the drill. The extent of the several formations which lie beneath the Coal Measures has not been tested by a sufficient number of borings to permit even approximate calculations. The figures given are largely conjectural.

Geologic column of Illinois.

\begin{tabular}{|c|c|c|}
\hline Formation. & $\begin{array}{l}\text { Extent in } \\
\text { State. }\end{array}$ & Thickness. \\
\hline Wisconsin drift sheet (Pleistocene). & $\begin{array}{r}\text { Square miles. } \\
19,000\end{array}$ & $\begin{array}{l}\text { Feet. } \\
\quad 5-200\end{array}$ \\
\hline Iowan drift sheet and main loess deposit (Pleistocene) - & a 45,000 & $5-60$ \\
\hline Illinoian drift sheet (Pleistocene) ... & 53,000 & $10-200$ \\
\hline Kansan drift sheet (Pleistocene).... & $\pm 1,800$ & $\pm 10-100$ \\
\hline Pre-Kansan drift-sheet? (Pleistocene) .... & $?$ & $?$ \\
\hline Tertiary deposits (perhaps of two or more epochs). & 700 & $\pm 10-100$ \\
\hline Cretaceous deposits. . & \pm 10 & ? \\
\hline Permian beds?......... & ? & ? \\
\hline Upper Coal Measures (Carboniferous) .. & 19,000 & $\pm 10-700$ \\
\hline Lower Coal Measures (Carboniferous) . . . . . . . . . . . & 36,000 & $\pm 10-1,000$ \\
\hline Conglomerate sandstone (Carboniferous) ....... & $\pm 30,000$ & $20-500$ \\
\hline Chester group (Carboniferous) ... & $\pm 15,000$ & $10-800$ \\
\hline St. Louis group (Carboniferous) .... & $\pm 30,000$ & $20-250$ \\
\hline 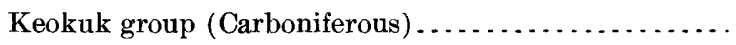 & $\pm 30,000$ & $100-200$ \\
\hline Augusta or Burlington limestone (Carboniferous). & $\pm 30,000$ & $25-200$ \\
\hline Kinderhook group (Carboniferous). & $\pm 30,000$ & $50-330$ \\
\hline Black slate (Devonian) .......... & $\pm 35,000$ & $10-60$ \\
\hline Hamilton limestone (Devonian)... & $\pm 35,000$ & $10-120$ \\
\hline Corniferous limestone (Devonian)... & $?$ & $5-25$ \\
\hline Oriskany sandstone (Devonian). & $?$ & $40-200$ \\
\hline Niagara group (Silurian) ......... & $\pm 45,000$ & $70-400$ \\
\hline Hudson River group (Ordovician) ...... & $\pm 48,000$ & $40-275$ \\
\hline Trenton group (Ordovician) .......... & $\pm 55,000$ & $45-450$ \\
\hline St. Peter sandstone (Ordovician) ....... & $\pm 55,990$ & $40-420$ \\
\hline Lower Magnesian limestone (Cambrian) ............ & 56,000 & $\pm 200-1,000$ \\
\hline Potsdam sandstone (Cambrian) . & 56,000 & $\pm 300-1,000$ \\
\hline
\end{tabular}

$a$ The loess covered all of Ilinois outside the Iowan drift, but was in part taken up by the Wisconsin ice sheet.

The entire thickness of the Paleozoic series of rocks ranges probably from a little more than 2,000 to possibly 6,000 feet. Two borings just outside the State at Burlington, lowa, and St. Louis, Mo., are reported to have reached pre-Cambrian rocks at 2,400 and 3,800 feet, respectively. So far as known to the writer no wells in the State have reached the bottom of the Paleozoic system, though several have been sunk to depths of more than 3,000 feet. One at Aledo, only a 
few miles from the Burlington well, terminated in Potsdam sandstone at a depth of 3,115 feet, and one at the Jacksonville waterworks has a depth of 3,028 feet. Probably the deepest boring in the State is one at St. John, Perry County, which reached a depth of 3,750 feet, and may not have entered the Potsdam sandstone.

\section{PRINCIPAL WATER-BEARING FORMATIONS.}

Potsdam sandstone.-The Potsdam sandstone is by far the most capacious water-bearing formation in the State. It is a porous rock, and as it is very thick and outcrops over a large area in Wisconsin, the intake is sufficient to give an unlimited supply of water to wells which reach this formation in Illinois. It is, however, within easy reach of wells only in a few counties in the northern and western portions of the State. In the northern part it has been reached by numerous wells as far south as Illinois River and is probably within reach of wells in the portion of the State west of the south-flowing part of the river. On the north border of the State the water is sufficiently fresh in most cases to be suitable for drinking, but upon passing southward it becomes brackish and in many cases unsuitable for domestic use.

St. Peter sandstone.-Next after the Potsdam sundstone should be mentioned the St. Peter sandstone, which is the source of supply for a large number of artesian wells in the northern and western parts of the State. The quality of water obtained from it is usually good, and is adequate to the needs of the smaller cities and towns. But in the larger cities, especially in Chicago, it can scarcely furnish the amount of water needed, and for that reason many wells have been sunk to the Potsdam formation. The porous or water-bearing portion of the formation varies from a thickness of 40 feet up to 150 feet or more.

In several instances wells have obtained good supplies of water from the sandstone beds which appear in the Lower Magnesian formation between the Potsdam and St. Peter sandstone. It is found that this formation is made up more largely of sandstone beds in northern Illinois than in the region of outcrop in Wisconsin, as may be seen by records of wells published in the reports by the author above cited.

Galena limestone.-The Galena limestone is very largely of porous rock, and in the region of outcrop in northern Illinois is a good waterbearer. The drill has shown that parts of it, buried deeply beneath later formations in western Illinois, will yield strong artesian wells, so that it is unnecessary at such points to sink to the St. Peter or lower formations.

Niagara limestone.-The Niagara limestone is another great waterbearer, not only in northern Illinois, where it immediately underlies the drift, but often also when under the cover of other rocks. The water seems in many cases to be traversing the formation in streams 
or veins, probably along fissures, and the depth to these veins may vary greatly in neighboring wells. The fissures were probably opened widely by atmospheric action before the formation was buried beneath the drift or older rocks. An objectionable feature of many wells obtaining water from the Niagara limestone is the presence of sulphureted hydrogen, formed from the decomposition of pyrites present in the limestone. There are, however, numerous wells in which this is not a pronounced feature, and the water is otherwise palatable and wholesome.

Devonian limestones. - The Devonian limestones are ordinarily poor water-bearers compared with the Niagara limestone, yet, in certain localities, they afford sufficient water to supply local needs. Their outcrop is also much more restricted than that of the Niagara, being confined to small areas in the western and southern parts of the State.

St. Louis limestone.- -The limestone formations of earlier Carboniferous age have outcrops over several counties in western and southern Illinois, and, though not great water-bearers, are drawn upon largely where the glacial deposits are either wanting or are too thin to supply the water.

Chester sandstone.-The Chester group of southern Illinois contains sandstones which are generally good water-bearers, but their outcrop is limited and they soon pass to so great a depth as to make drilling to them expensive. The water in the deep-lying beds is also liable to be brackish or unsuitable for domestic use.

"Conglomerate" sandstone. -The "Conglomerate" sandstone which underlies the Coal Measures in central, eastern, and southern Illinois is not likely to become a valuable source of water for domestic use, for it is a very thin formation in the northern part of its field, and where thick in the southern part is generally buried deeply under Coal Measures. In the latter situation it is usually charged with salt water.

Coal Measures.--The sandstone beds of the Upper and Lower Coal Measures constitute probably half the thickness of the formations, and they are generally permeated with water which, however, is suitable for domestic use only at a few horizons, usually within 200 feet of the surface, for at other horizons and at greater depth there are often either salt or sulphates to render the water objectionable. These formations, however, usually supply the needs of residents in places where the drift cover does not furnish a sufficient amount of water.

Tertiary deposits. - The Tertiary deposits are of limited extent and shallow depth and afford a very unimportant part of the water supplies of the State. In the region where they occur wells are often sunk to the underlying limestone.

Glacial deposits. - The glacial deposits are probably more often drawn upon than all other formations combined, for they are surface formations and the water is reached by wells of moderate depth such as 
nearly every resident can afford. There are probably more than a half million wells in these deposits. The complexity of the glacial formations, however, is such that in a large part of the glaciated area it is difficult to forecast the results of boring into them. It is estimated that about 70 per cent of the glacial drift is a compact clayey material affording very little water, except by slow seepage. The remaining 30 per cent would, if distributed to the best advantage, be adequate to the needs of residents. But unfortunately there are tracts of considerable extent in which the drift is almost wholly of a clayey constitution, while other tracts have a superabundance of water-bearing material. A somewhat detailed study of these deposits has shown that the distribution of the sand and gravel beds depends to a large degree upon the drainage conditions attending the melting of the ice. In the repeated advances which the ice made into this region the sand and gravel beds distributed by the water from the melting of a given ice sheet were overridden and buried deeply in places by the deposits from a later ice sheet. Then, too, there appear to have been minor oscillations of the ice front in each stage of glaciation by which sand and gravel beds, which had been spread out at the edge of the ice sheet, were covered by clay deposits laid down during the readvance of the ice. In western and southern Illinois the sand and gravel found in the drift seem to have been deposited as the result of these minor fluctuations, for they are distributed in very irregular and limited areas. In central, eastern, and northeastern Illinois there are, in addition to such beds, more extensive ones lying between the main drift sheets. It is also found that throughout the State a large amount of sand and gravel and abundance of water are usually found along the line of pre.-Glacial valleys. In the northern part of the State, north from a line running from Rock Island to Watseka, there is a large amount of gravelly and sandy drift at or near the surface. Farther south the surface sand and gravel are generally restricted to the valleys of the main drainage lines. Pl. XVI indicates the relation of the drift to the wells. It shows the areas in which wells are obtained almost wholly from the drift, areas in which drift and rock wells are each used extensively, and areas in which it is generally necessary to go into the rock to obtain water. There are inany weak wells within the areas of thick drift, but in the great majority of cases farmers have penetrated to waterbearing beds or veins, which afford an adequate supply.

\section{IOCALITIES FAVORABLE FOR ARTESIAN WELIS.}

Artesian wells as here discussed include only wells which overflow, whether from the rock or from the glucial formations. It should be understood, however, that a large number of wells not classed as artesian are under the same hydrostatic pressure as those that flow and the water rises to a similar altitude above sea level. 


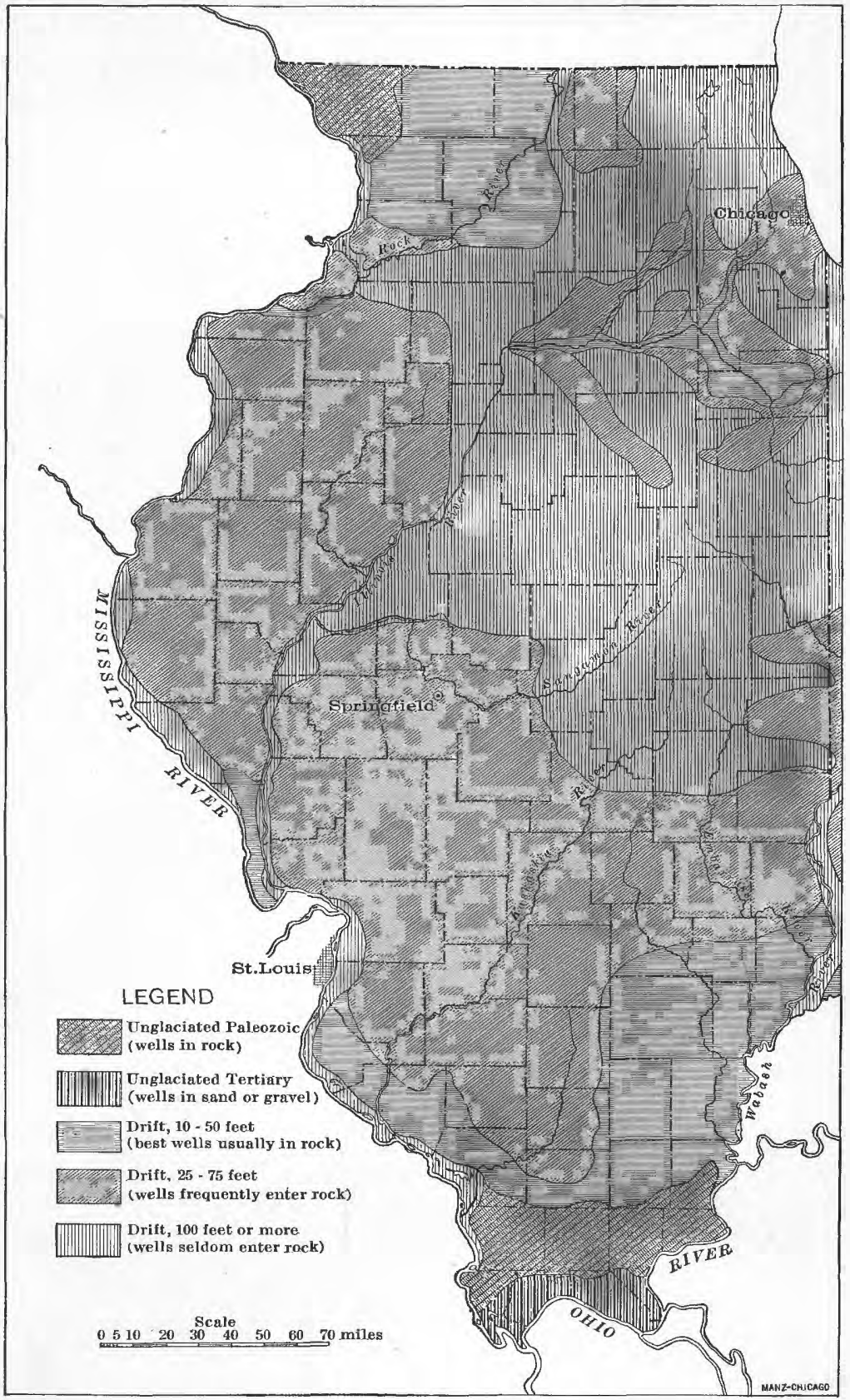

MAP SHOWING THICKNESS OF DRIFT IN ILLINOIS. 
The artesian wells obtained from the several rock formations in northern and western Illinois must generally be situated on ground less than 700 feet above sea level, for it is well established that water will not rise above that height, except in the extreme northern part of the State or in localities where the greater head is obtained from drift formations, which constitute the main source of supply for the wells. In southwestern and southern Illinois the ground must be considerably lower than in northern and western Illinois to obtain a flow. In the latitude of St. Louis, and south from there, the head is generally as low as 500 feet above tide, and flows are obtained only at a few points, there being a less uniform head or hydrostatic pressure than in the northern and western parts of the State. The most favored part of the State for deep artesian wells is that lying north and west of Illinois River. The following section (fig. 40) is along a line from Wisconsin River in western Wisconsin southward to Cap au Grès near the mouth of Illinois River through a region where artesian wells are very successful. It will be observed that northward from Aledo the section shows but one shale bed - the Hudson - and this is wanting north of Galena, but south from Aledo the Kinderhook, Devonian, and Coal Measures shales comprise a considerable portion of the section. It is thought that the intake is not restricted to the outcrop of the sandstone in Wisconsin, but that the limestones and other pervious beds farther south take in a large amount of water.

There are only a few small areas in Illinois in which the drift furnishes flowing wells. These areas are usually on the slopes of moraines, or along valleys in which there is a thick filling of drift. The intake appears to be on the moraines or possibly on outlying gravel plains in the

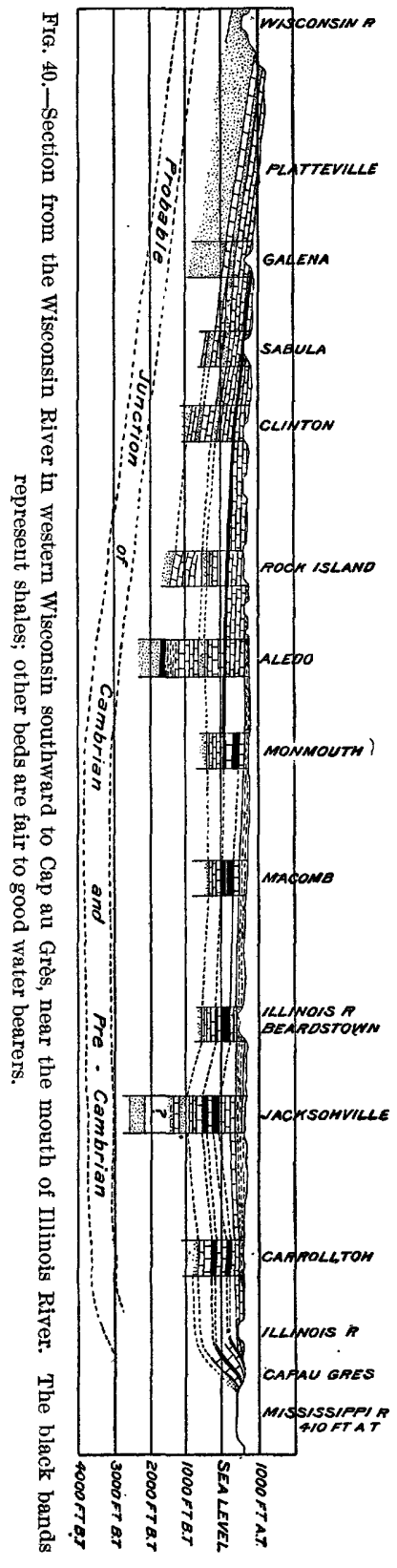
first instance, and on higher ground bordering valleys in the second instance. In these wells, as in those which obtain their supply from the rock, the rise of water, or hydrostatic pressure, is in many cases 
no greater than in neighboring wells that do not overflow, the overflow being due to the low altitude of the surface. The largest flowing well district is in a basin lying on the north slope of a morainic system in Iroquois County and border portions of adjacent counties in eastern Illinois, and comprises an area of about 500 square miles. There is a smaller district with exceptionally strong flows around Potomac, in northern Vermilion County. Other small districts occur near Plattville, in Kendall County; near Earlville, in northern Lasalle County; near Sycamore, in northern Dekalb County; near Palatine, in northern Cook County, and along Salt Creek Valley, in northern Cook and eastern Dupage County. There are a few flowing wells along the north fork of Chicago River, in northern Cook and southern Lake counties. Flowing wells are also common in low-lying tracts among moraines of Lake, McHenry, and Kane counties. The combined area of all these small districts will probably not greatly exceed that of the Iroquois district (500 square miles). Occasional flowing wells are scattered over the central part of the State, chiefly along river valleys, and there are very few in the western and southern portions in similar situations.

\section{WATERS IN RELATION TO HABITATION.}

The census of 1900 gives Illinois a population of $4,821,550$, which warrants the assumption of a present population of about 5,000,000. About half of this population derives the supply for drinking and many other domestic uses from surface water, Lake Michigan furnishing water for the 2,000,000 or more people of Chicago, and several other small cities along the lake, and the streans of the State furnishing a supply for about 300,000 people living in the small cities and villages. It is estimated that about a half million people obtain their drinking water from wells of considerable depth. There thus remains about $2,000,000$ people who are supplied from wells of shallow depth. A small part of the population, residing principally in the driftless parts of the State, depend entirely upon rain water collected in cisterns, and rain water is used to a small extent in every community throughout the State for drinking water, and is used extensively for other domestic purposes. Spring water is also in use to a very limited extent throughout the State.

The chemical survey of the waters of the State instituted at the University of Illinois in 1895, and conducted by Prof. A. W. Palmer, has called attention to the quality of the water from the several sources in use. Up to the present time about 11,000 sanitary analyses and 500 mineral analyses have been made, representing conditions in 100 of the 102 counties and about 500 cities, villages, and hamlets. From the 
latest report, ${ }^{a}$ covering the period 1897 to 1902 , inclusive, the following results of the survey are taken. The rain water in use by the residents is seldom properly filtered and the ordinary cistern filter, "as commonly managed or rather neglected, frequently is almost worse than useless, inasmuch as it soon becomes surcharged with matters which it has removed from some of the water, and then, instead of purifying the water that subsequently passes through, often becomes a source of offense if not of danger."

"In general, water taken from lakes, from streams, or from the ground, when these sources of supply are in their original or natural condition, is perfectly wholesome and unobjectionable, but with increasing population and longer occupancy of the ground the conditions change and contamination becomes inevitable." For this reason Professor Palmer remarks that it would be best for even the people of the smallest towns to use for drinking purposes only the water supplied by one general plant, the sanitary condition of which could and should be thoroughly and periodically investigated by experts acting under the direction of a water commission or the State board of health.

This chemical survey has shown that the normal shallow drift waters contain chlorides, sulphates, carbonates, and silicates of calcium, magnesium, potassium, and sodium, with minute quantities of iron and aluminum compounds, together with considerable quantities of nitrates, but only minute quantities of saline ammonia and albuminoids; organic matters are almost entirely absent; nitrites are frequently present in notable quantity. The normal deep drift waters contain in general the same mineral salts as the shallow waters, but usually the quantity of iron is considerable, and the nitrates are either entirely absent or present in but minute quantity, while free ammonia is abundant and albuminoids are present in considerable quantities. "Oxygen consumed" is high, and the water residue blackens upon being heated, showing that it contains much organic matter. The waters from shallow wells are well aerated and are clear, sparkling, cool, and of agreeable taste; those from the deeper wells contain little or no oxygen, possess in many cases a disagreeable taste, due to the presence of marsh gas, accompauied occasionally by minute quantities of sulphureted hydrogen, and are either turbid or become turbid quickly on exposure to air, owing to the oxidation of the iron carbonate which they contain and the consequent precipitation of insoluble ferric compounds.

"Although these unpleasant characteristics of the deep drift waters give rise to much prejudice and objection to their general use for drink, nevertheless, from the sanitary standpoint they are usually to

$a$ Chemical Survey of the Waters of Illinois. Report for the years 1897-1902, by Arthur William Palmer. Published by the University, 1903, 254 pages. 
be preferred to the clear and palatable waters of the shallow wells, since the evidence of numerous analyses shows that they are less subject to pollution with refuise animal matters than are the latter, while the organic matters which they contain are derived from buried vegetable remains and are comparatively harmless. ${ }^{a}$

\section{MINERAI SPRINGS.}

Though not so abundant as in more rugged areas, springs are nevertheless numerous in Illinois. Those of the drift are probably the most abundant numerically, but the individual springs are generally small, sometimes being mere seeps. Such waters vary in character according to the constitution of the drift, but in general they are hard, and frequently carry considerable iron in solution. In the Coal Measure rocks they are very often highly charged with iron sulphate or carbonate, salt, hydrogen sulphide, etc., while in the limestone the waters are generally very hard. Springs are numerous, and sometimes of considerable size in the limestones and older sandstones, especially along the bluffs of Mississippi River.

A considerable number of the mineral springs are the sites of resorts of more or less importance. Many report sales of water for medicinal or table purposes. The 22 springs reporting to the United States Geological Survey in 1902 are as follows: ${ }^{b}$

Abana Spring, Libertyville, Lake County.

Anna or Cave Mineral Springs, Anna, Union County.

Aqua Vitæ Mineral Springs, near Maquon, Knox County.

Aurora Lithia Spring, Montgomery, Kane County.

Black Hawk Springs, Rock Island, Rock Island County.

Blue Grass Springs, Montgomery, Kane County.

Cumberland Mineral Spring, near Greenup, Cumberland County.

Deer Lick Mineral Spring, Dearfield, Lake County.

Diamond Mineral Spring, Grantfork, Madison County.

Elmhurst Mammoth Spring, Elmhurst, Dupage County.

Glen Flora Mineral Springs, Waukegan, Lake County.

Gravel Springs, near Jacksonville, Morgan County.

Macinac Mineral Spring, Woodford County, near Carlock.

Magnesia Spring, Montgomery, Kane County.

Min-ni-Ni yan Spring, Bristol, Kendall County.

Mokena Mineral Spring, Mokena, Will County.

Original Springs, Okawville, Washington County.

Perry Mineral Springs, Perry Springs, Pike County.

Red Avon Mineral Spring, Avon, Fulton County.

Sanicula Springs, Ottawa, Lasalle County.

Sylvan Dell Spring, Galewood, Cook County.

White Diamond, formerly Spouting Mineral Spring, South Elgin, Kane County.

a Chemical Survey of the Waters of Illinois. Report for the years 1897-1902, by Arthur Williarn Palmer. Published by the University, 1903, pp. 8-9.

b Peale, A. C., Mineral Resources U. S. for 1902, U. S. Geol. Survey, 1904, p. 996. 
The aggregate sales of these 22 springs are given as $1,767,955$ gallons, with a value of $\$ 89,565$.

\section{PRINCIPAL PUBLICATIONS.}

Mineral springs of the United States, by A. C. Peale. Bull. U. S. Geol. Survey No. 32, pp. 142-144.

Preliminary list of deep borings in the United States, pt. 1, by N. H. Darton: Water-Supply and Irrig. Paper U. S. Geol. Survey No. 57, pp. 25-30

Water resources of Illinois, by Frank Leverett: Seventeenth Ann. Rept. U. S. Geol. Survey, pt. 2, pp. 695-849.

Wells of Illinois, by Frank Leverett: Mon. U. S. Geol. Survey, vol. 38, pp. 550-787. Description of the Danville quadrangle, by M. R. Campbell and Frank Leverett: Geol. Atlas U. S., folio 67, U. S. Geol. Survey.

Description of the Chicago district, by W. C. Alden: Geol. Atlas U. S., folio 81, U. S. Geol. Survey.

Description of the Patoka quadrangle, by M. L. Fuller and F. G. Clapp: Geol. Atlas U. S., folio 105, U. S. Geol. Survey.

Geology of Illinois as related to its water supply, by Charles W. Rolfe: Report on Chemical Survey of the Waters of Illinois. University of Illinois, 1903, pp. 41-56. 


\section{INDIANA.}

\section{By Frank Leverett.}

\section{INTRODUCTORY STATEMENT.}

This brief discussion of water conditions in Indiana, like that of Illinors, is restricted chiefly to the relative value of the several geologic formations as water bearers. A more detailed discussion of drainage systems, underground waters, mineral springs, and water supplies for cities and villages will be found in a paper ${ }^{a}$ by the author which appears in the Eighteenth Annual Report of the United States Geological Survey (pp. 425-559) and a discussion of the wells of Indiana, taken up county by county, in Water Supply and Irrigation papers Nos. $21^{b}$ and $26 .^{c}$ The geologic structure of Indiana has been discussed in part or as a whole in several of the reports of the State geological survey, but except the very excellent discussion of mineral waters in the Twenty-sixth and Twenty-seventh Annual Reports, the State reports contain little information concerning water supplies. A paper on the "Natural Gas Field of Indiana," by A. J. Phinney, in the Eleventh Annual Report of the United States Geological Survey (pp 509-742), presents many data concerning water supplies.

\section{GEOLOGIC COLUMN.}

The formations exposed in Indiana extend with but slight breaks from the Hudson River group to the Coal Measures. There is then a wide gap, the next formation being of Tertiary (?) age, after which another interval appears between the Tertiary (?) and the glacial formations. The table on page 259 gives the formations penetrated by the drill, beginning with the newest and extending to the oldest. It also includes the formations below the Hudson River group which have been reached by the drill.

$a$ Water resources of Indiana and Ohio.

$b$ Wells of northern Indiana.

$c$ Wells of southern Indiana. 
Generalized section of the rock formations of Indiana.

[Modified from section of A. J. Phinney in the Eleventh Annua] Report of the U. S. Geological Survey, pp. 624-625.]

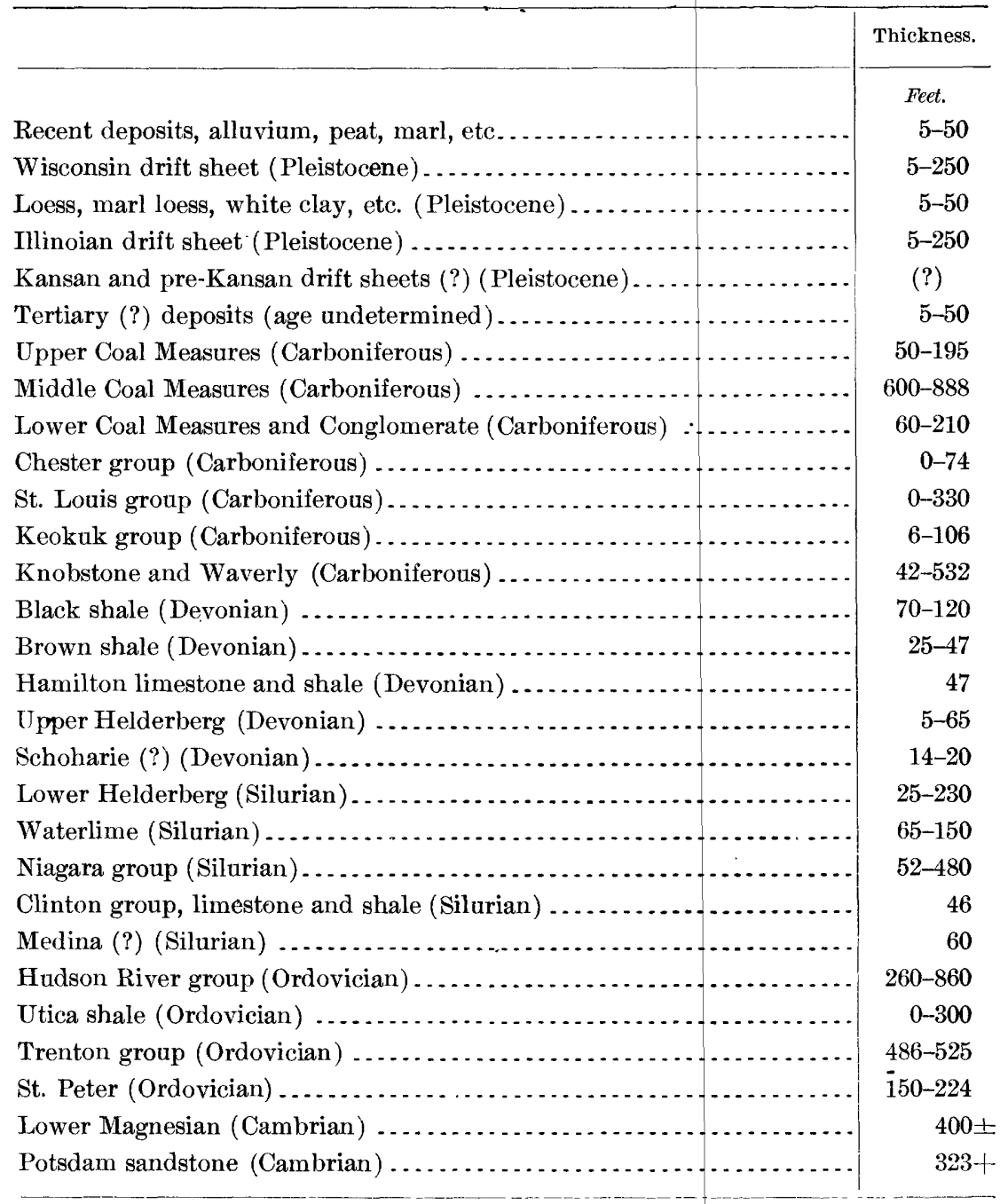

\section{PRINCIPAL WATER-BEARING FORMATIONS.}

St. Peter sandstone.-The St. Peter sandstone, in the Indiana field, usually is a calcareons, loose-textured rock, saturated with salt water, containing more or less sulphate of magnesia and sulpureted hydrogen. It may, however, be potable in the extreme northwest part of the State.

Trenton limestone.-The porous portion of the Trenton limestone, except in parts of the State where it carries natural gas and oil, is also saturated with salt water, the water taking the place of the gas and oil as the latter become exhausted by pumping.

IRR $114-05-18$ 
Hudson beds.-The Hudson group is a very poor water bearer, being composed largely of shale. It is used to a limited extent, however, at its outcrop in the southeastern part of the State to supply water for domestic use.

Clinton and Medina beds. - The Clinton and Medina are comparatively thin formations with very limited areas of outcrop, and are, as a rule, inferior water bearers.

Niagara limestone.-The Niagara group consists largely of a limestone which, as in Illinois, contains a large amount of water, generally palatable and suitable for domestic use. In some cases, as in Illinois, the water is charged with sulphureted hydrogen produced through the decomposition of pyrite included in the limestone. This limestone furnishes probably the most abundant supply of water suitable for domestic use to be found in any single rock formation, since it is struck at moderate depth in much of the eastern part of the State. When it passes under the cover of later formations and sinks to considerable depths the water becomes brackish and is unsuitable for domestic use.

Waterlime and Lower Helderberg limestones.-The limestone formations above the Niagara to the base of the Devonian shale afford good supplies of water in the region of outcrop, water being generally struck in veins or fissures, as in the Niagara limestone. The outcrops are, however, comparatively few, since these formations are ordinarily buried under very heavy deposits of drift. Their value as water bearers is found chiefly along the Wabash Valley above Delphi and in the southern part of the State, where the drift is thin or wanting.

Devonian shale.-The Devonian shale which underlies heavy deposits of drift in the northern part of the State and also a narrow strip leading west of north from Ohio River at New Albany to the Tippecanoe near Monon is perhaps the poorest water-bearer in the State, but it is so generally deeply covered by water-bearing beds of drift that there is little need of penetrating it.

Waverly shale.--The Waverly shale, which is found on the north border of the State, like the Devonian shale, is a very poor waterbearer, and like it, too, is concealed deeply beneath water-bearing beds of drift.

Knobstone formation. - The Knobstone formation from the central part of the State southward constitutes the knobs or most hilly tracts of southern Indiana, and includes some sandstones as well as shales. It is covered by drift north from northern Brown County, and the drift-covered portion is not drawn upon for wells to any notable degree. The driftless portion of this formation is only sparsely settled and the residents depend to a large degree upon springs which issue from the sandstone beds along the valley slopes. The water is ordinarily fresh and much softer than that obtained from neighboring limestone formations. 
Whosica -1 Lasins.

U. S. GEOLOGICAL SURVEY

WATER-SUPPLY PAPER NO. 114 PL XVII

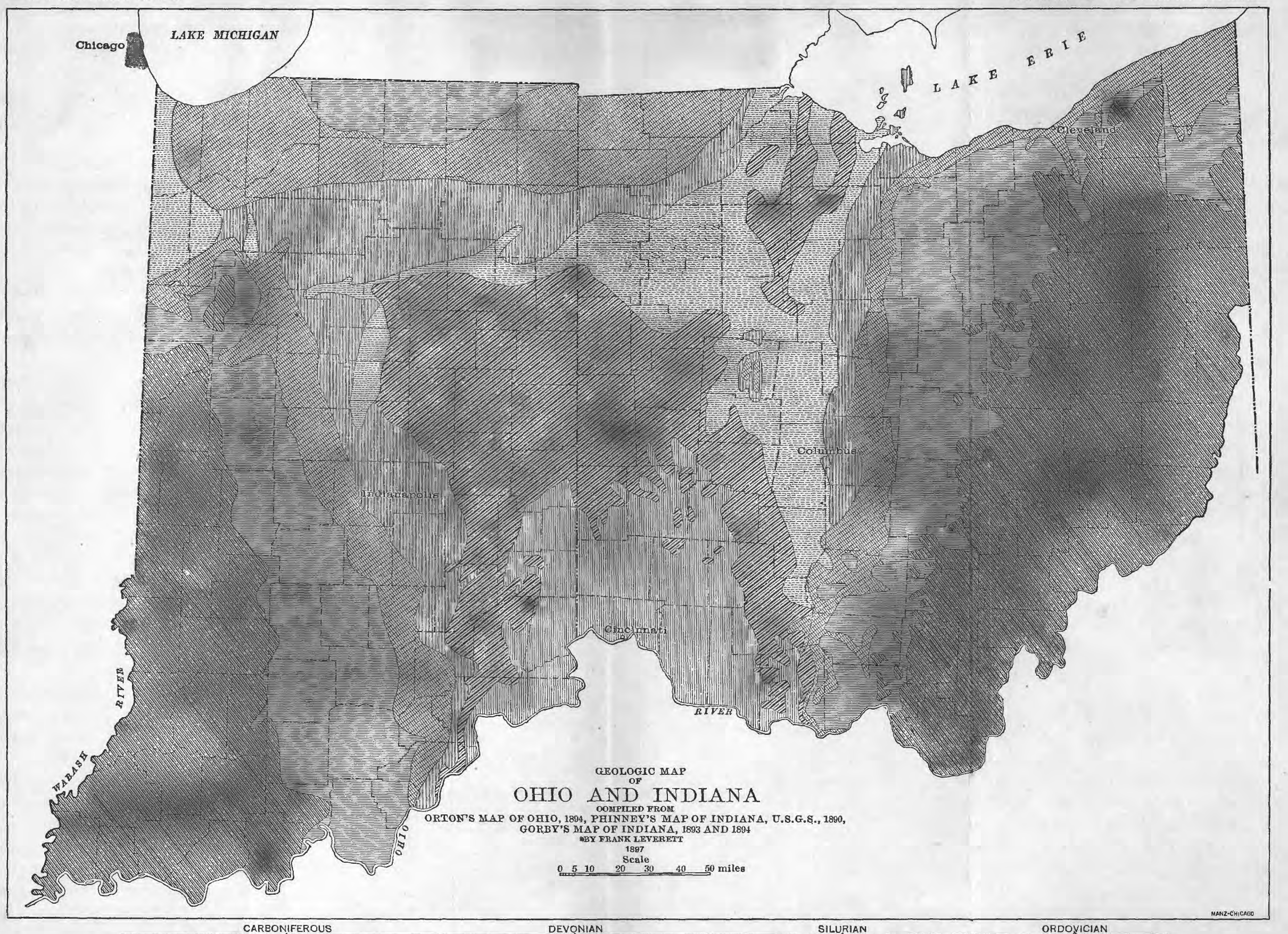

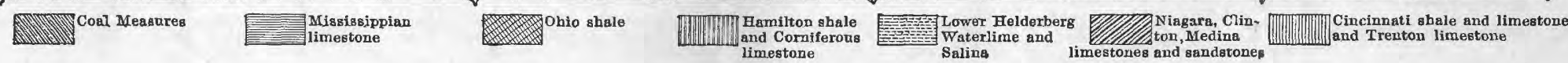


St. Louis limestone beds.-The St. Louis limestone belt occupies in its outcrop a width of about 20 miles, and extends from Ohio River in Harrison County, west of north through Washington, Orange, Lawrence, Monroe, Owen, Morgan, Putnam, and Montgomery counties to the borders of the. Wabash Valley above Attica. It is unglaciated as far north as northern Monroe County, and furnishes the sole supply for the residents, with the exception of the rain water collected in cisterns. There are some localities in which the expense of sinking wells into the limestone far enough to strike water is so great that cistern water has come into use for drinking as well as for other domestic purposes. In the drift-covered portion of this limestone belt a large part of the wells are obtained without entering the limestone, though its several members appear to be good water bearers wherever penetrated.

Chester sandstone.-The sandstones which come in between the limestone group and the Coal Measures form a narrow strip running from Perry County, on Ohio River, west of north to the Wabash Valley at the vicinity of the great bend near Attica. The region between Ohio River and White River is either driftless or carries only a thin deposit of drift, and the sandstone supplies water at moderate depths and also is the source of many springs, usually of fresh water.

Coal Measures.--The Coal Measures of the southwestern part of Indiana are either unglaciated or covered to only a slight depth with drift, but in western Indiana they are so thickly covered that wells are either obtained in the drift or at the junction of the drift with the rock. Wells which have been sunk into the rock have in some cases struck "copperas water" at moderate depths, and salt water is usually encountered at depths of more than 200 feet. To obtain good water in this region exploration should be made by the drill until fresh water free from sulphates has been reached. Waters with objectionable properties which occur at higher levels can then be cased out, as is impracticable when the wells are dug. In some localities it seems necessary to use rain water collected in cisterns, the sulphates in the waters from the rock being so generally present that good wells are very difficult to obtain.

Tertiary deposits.-The Tertiary deposits are of very limited extent, and the only places in which they appear to be of value as waterbearers are found where the gravels have been redeposited in the Ohio Valley, in which case they sometimes yield springs of considerable strength, some of which are to be found below Rockport.

Drift.-The glacial deposits of Indiana extend to Ohio River, in the southeastern part of the State, but the drift border runs northward from near Jeffersonville to northern Brown County, and thence westward into Monroe County, passing a little north of Bloomington. The 
course is then southwestward across Greene, Martin, Dubois, Pike, Gibson, and Posey counties to the mouth of the Wabash. From about the latitude of Indianapolis southward the thickness of the drift is very moderate, except along the line of pre-Glacial valleys, but in nearly all parts of the State north of this latitude there is a heavy deposit which in places reaches a thickness of 500 feet, and averages about 200 feet. The average thickness in the entire glaciated portion of the State is estimated to be about 130 feet. There are a few counties in the southeastern part, and small tracts in the southwestern, where the drift is composed very largely of compact clayey material, which is such a poor water-bearer that wells have been sunk into the rock formations. Elsewhere in the State it is the exception to find a well extending to the rock without encountering more or less waterbearing gravel and sand. In the areas of thickest drift the gravel and sand generally greatly preponderate over clayey material. The large amount of gravel and sand in the drift of this State seems due to the fact that there was a crowding or converging of ice lobes which entered the State from the great basins of Lake Michigan, Saginaw Bay, and Lake Erie, which would naturally produce a great amount of glacial drainage.

In the Illinois district, where the single ice lobe from the Lake Michigan basin was free to spread widely, the streams occupied only a small part of the glaciated area, and thus left wide strips in which there was very little movement of waters to carry away the clayey material. In Indiana as well as in Illinois there were oscillations of each of the several ice lobes, which have resulted in alternations of beds of various degrees of coarseness and permeability to water. In the final retreat of the ice an extensive but comparatively thin sheet of sand was deposited over the district between the Kankakee and Tippecanoe rivers in northwestern Indiana, but elsewhere in northern Indiana the surface capping is largely clay. The inferior quality of much of the water in the rock formations of Indiana is more than made good by the great abundance of excellent water in the drift, so that the State is, as a whole, highly favored in its water supply for all domestic uses.

The map of Indiana and Ohio, PI. XVIII, shows not only the relation of the wells to the drift, but also the parts of the State in which the drift is of exceptional thickness. It should perhaps be stated that in the portion where the drift is but 25 to 75 feet thick wells are commonly obtained without entering the rock, and rock wells are nearly as rare as in the districts where there is more than, 100 feet of drift. 


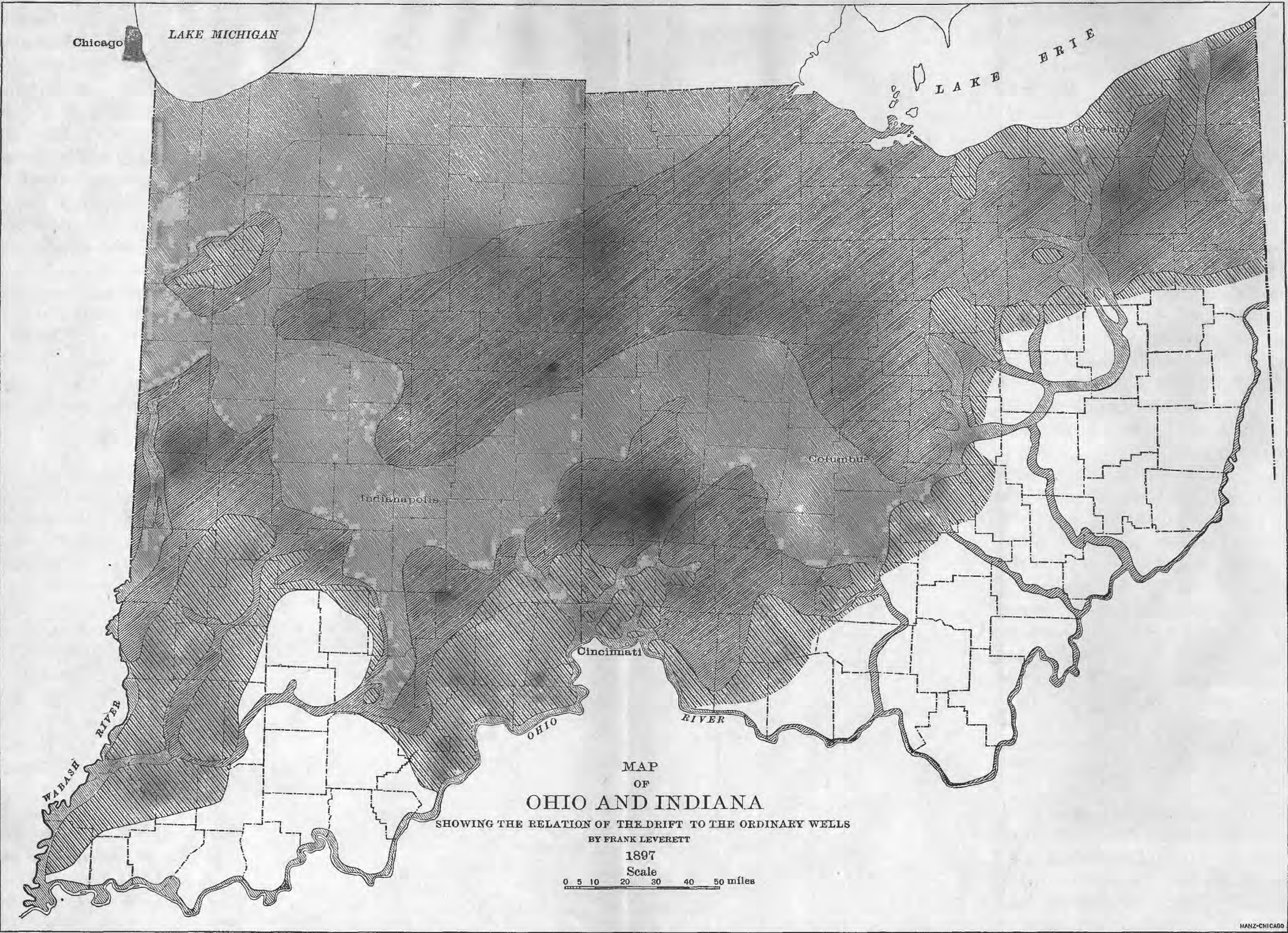

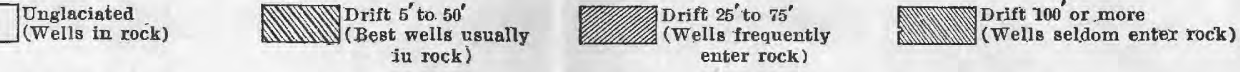




\section{LOCALITIES FAVORABLE FOR ARTESIAN WELLS IN INDIANA.}

There are no extensive areas in this State where artesian wells may be obtained, except perhaps in the northwestern counties where the conditions are similar to those of the neighboring part of 'Illinois. Elsewhere occasional flows have been obtained in the valleys of the main streams or exceptionally low parts of interfluvial tracts. The deep borings were sunk usually for the purpose of obtaining oil or gas, little attention being given to the head attained by water. The data are therefore insufficient to warrant definite statements concerning the head to be expected at any given place or conclusions concerning the regularity or lack of regularity in the hydrostatic pressure.

Flowing wells from the drift have only been obtained in very small areas, which, like those of Illinois, are situated usually on the iceward side of prominent moraines or in the valleys. Numerous instances will be found recorded in the papers by the author referred to above.

\section{MINERAL WATERS.}

Mineral waters are of common occurrence in Indiana, and include the waters of both springs and wells. Mr. W. S. Blatchley has recently made an extended study of such waters and has published a detailed report treating of their character and uses. ${ }^{a}$ Over 100 springs or wells are described and a large number of analyses given. Dr. Robert Hessler has made a report on the medicinal properties and uses of Indiana mineral waters. ${ }^{b}$

Springs occur in nearly all parts of the State and in rocks of widely different types. Those from the coal-bearing rocks of the Carboniferous are relatively small, but carry large amounts of mineral matter, especially salt, iron sulphate, iron carbonate, and hydrogen sulphide. The springs in the limestone regions generally carry much lime, but hold little of the substances mentioned as characterizing the Coal Measure rocks. Some of these are of great volume, welling up from fissures, or from between beds, or emerging from caves. In some instances the volume is sufficient to furnish water power for mills.

Up to 1886 few deep wells had been drilled, but since that date more than 14,000 bore holes have been sunk. Some of these flowed, and in many others the water rose nearly to the surface. Large supplies are sometimes obtained. Much of the water is highly mineralized and of medicinal value, and wells have been developed in many instances into important resorts.

aIndiana Dept. Geol. Nat. Resources, Twenty-sixth and Twenty-seventh Ann. Repts., pp. 11-158. b Ibid., pp. 159-224. 
The water is to a considerable extent used at the individual wells or springs, but in 1902 shipments from 16 springs amounted to 273,380 gallons, with a value of $\$ 236,501$. The average price per gallon is the highest in the country. ${ }^{a}$ Following is a list of the springs reporting:

Attica Lithia Springs, Attica, Fountain County.

Elliott Springs, Willow Valley, Martin County.

Emerald Spring, Indiana Mineral Springs, Warren County.

French Lick Springs, French Lick, Orange County.

Greenwood Mineral Well, Greenwood, Johnson County.

Kickapoo Magnetic Spring, Kickapoo, Warren County.

King's Mineral Spring, Muddyfork, near Dallas, Clark County.

Laxine Spring, Mount Moriah, Brown County.

Lodi Artesian Well, Silverwood, Fountain County.

Magnetic Mineral Spring, Terre Haute, Vigo County.

Mudlavia, formerly Indiana Mineral Springs, Mudlavia, Warren County.

Mudlavia Artesian Sulphur Spring, Mudlavia, Warren County.

Porter Mineral Springs, near Porter's Depot, Porter County.

Shelbyville Lithia Spring, Shelbyville, Shelby County.

West Baden Springs, West Baden, Orange County.

Winona Lithia Spring, Winona Lake, Kosciusko County.

\section{PRINCIPAL PUBLications.}

Water resources of Indiana and Ohio, by Frank Leverett: Eighteenth Ann. Rept. U. S. Geol. Survey, pt. 4.

Wells of northern Indiana, by Frank Leverett: Water-Supply and Irrig. Paper U. S. Geol. Survey No. 21, 1899.

Wells of southern Indiana, by Frank Leverett: Water-Supply and Irrig. Paper U. S. Geol. Survey No. 26, 1899.

Description of the Danville quadrangle, by M. R. Campbell and Frank Leverett: Geol. Atlas U. S., folio 67, U. S. Geol. Survey.

Description of the Chicago district, by W. C. Alden: Geol. Atlas U. S., folio 81, U. S. Geol. Survey.

Mineral waters of Indiana, by W. S. Blatchley: Indiana Geol. Survey, vol. 26, pp. $11-158$.

The medicinal properties of Indiana mineral waters, by Robert Hessler: Indiana Geol. Surv., vol. 26, pp. 159-226.

Description of the Ditney quadrangle, by M. L. Fuller and G. H. Ashley: Geol. Atlas U. S., folio 84, U. S. Geol. Survey.

Description of the Patoka quadrangle, by M. L. Fuller and F. G. Clapp: Geol. Atlas U. S., folio 105, U. S. Geol. Survey: 


\section{HIO. \\ By Frank Leverett.}

\section{INTRODUCTORY S'TATFMEN'T.}

A somewhat detailed discussion of drainage systems, mineral springs, and water supply for cities and villages will be found in a paper by the author which appears in the Eighteenth Annual Report of the United States Geological Survey. ${ }^{a}$ The drainage features, both present and pre-Glacial, and the glacial formations in their relation to water supplies are treated at some length by the author in Monograph XLI of this survey. The rock waters and flowing wells of Ohio are discussed by Edward Orton in a paper in the Nineteenth Annual Report of the United States Geological Survey. The paper covers the subject of the relative value of the several geologic formations as waterbearers. In Ohio the State board of health is required by law to approve all public water supplies when introduced, and their reports may be consulted for analyses made in accordance with this law. A report published in 1898 contains an exceptionally full discussion of water supplies, and includes the paper by Orton, referred to above.

\section{GEOLOGIC COLUMN.}

[Modified from paper of Edward Orton in Nineteenth Annual Report of the U. S. Geological Survey.]

\begin{tabular}{|c|c|}
\hline Formation. & Thickness. \\
\hline & Feet. \\
\hline Recent deposits, alluvium, peat, marl, etc...... & $5-50$ \\
\hline Wisconsin drift sheet (Pleistocene) $\ldots . \ldots \ldots \ldots \ldots \ldots$ & $0-300$ \\
\hline The loess or white clay (Pleistocene) ..... & $3-15$ \\
\hline Illinoian drift sheet (Pleistocene) ..... & $10-250$ \\
\hline 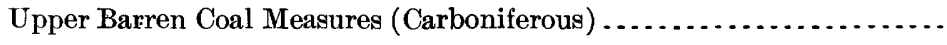 & $500 \pm$ \\
\hline Upper Productive Coal Measures (Carboniferous) .............. & $200 \pm$ \\
\hline Lower Barren Coal Measures (Carboniferous) ......... & $500 \pm$ \\
\hline Lower Productive Coal Measures (Carboniferous) ............ & $250 \pm$ \\
\hline Conglomerate Coal Measures (Carboniferous) & $250 \pm$ \\
\hline
\end{tabular}




\begin{tabular}{|c|c|}
\hline Formation. & Thickness. \\
\hline Logan group (Eocarboniferous) & $\begin{array}{l}\text { Feet. } \\
\quad 0-300\end{array}$ \\
\hline Cuyahoga shale (Eocarboniferous) $\ldots \ldots \ldots \ldots \ldots$. & $150-450$ \\
\hline Berea shale and grit (Carboniferous) $\ldots \ldots \ldots \ldots$ & $25-150$ \\
\hline Bedford shale and sandstone (Carboniferous) & $50-150$ \\
\hline Ohio shale, etc. (Devonian) .. & $250-2,500+$ \\
\hline Corniferous limestone (Devonian). & $25-100$ \\
\hline Onondaga limestone (Silurian). & $20-600$ \\
\hline Niagara group, limestone and shale (Silurian)..... & $150-350$ \\
\hline Clinton limestone (Silurian) .............. & $20-150$ \\
\hline 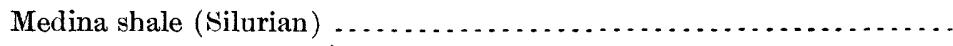 & $25-150$ \\
\hline Hudson River group, shales and limestones (Ordovician) ....... & $300-800$ \\
\hline Utica shale (Ordovician) ... & $0-300$ \\
\hline Trenton group (Ordovician) ... & $300-600$ \\
\hline
\end{tabular}

\section{CHARACTERISTICS OF WATERS OF DIFFERENT DEPTHS.}

The following general principles have been stated by Orton in the report above mentioned:

1. The subterranean waters from a comparatively shallow depth carry, as a rule, dissolved carbonates. Lime and magnesia are the leading bases, but potassium and sodium also occur in small quantities. Iron is unfailingly present, and often in notable quantity. These wells are common sources of potable supply.

2. Water from a greater depth holds dissolved chlorides as well. Chloride of sodium is by far the most common, but chlorides of magnesium and calcium are also often added. The presence of chlorides is seldom shown in water at less than 100 feet in depth, and where found they are confined to a few formations of the Ohio column. It is very rare that the drill descends to 300 feet without encountering saline water or water too highly mineralized with other elements to be acceptable for the highest uses. Aside from that of a few wells in glacial drift no water of the State is known that comes from a depth greater than 500 feet and still remains free enough from mineral solutions to warrant its use as potable.

3. Sulphates are generally found in the deeper waters, but are also found in the shallower waters. The most common compound is calcium sulphate; but sodium sulphate is not infrequent.

4. Sulphides also, particularly sulphureted hydrogen, though often rising to the surface in so-called sulphur springs, are especially characteristic of waters found in limestones, and nearly all of the water of the great Ohio shale system is characterized in this way. Sulphides pass into sulphates very promptly and by reactions easily understood.

\section{RELATIVE VALUE OF DIFFERENT ROCK FORMATIONS AS WATER-BEARERS.}

Of the large number of formations present in Ohio, as indicated in the section above, Orton considers only the following to be important water-bearers: Trenton limestone, Clinton limestone, Niagara limestone, Onondaga limestone, Corniferous limestone, Logan sandstone, 
Berea grit, Carboniferous conglomerates, and certain sandstone beds of the Coal Measures.

Trenton limestone.--The waters of the Trenton limestone are all highly mineralized and have a strong, bitter, or saline taste; they are also charged heavily with sulphureted hydrogen.

Clinton limestone.-The Clinton limestone affords a large number of springs along its outcrop in Preble, Montgomery, Warren, Greene, and Clinton counties. This limestone when under a deep cover of later formations carries water too highly mineralized for a potable supply. It is therefore utililized for domestic purposes only along the line of outcrop.

Niagara limestone.-The Niagara limestone contributes its most important supplies of water where it immediately underlies the glacial drift in a few counties in the western part and a narrow strip leading from there southward to Ohio River in Adams County. Orton refers to the effect of atmospheric agencies in enlarging the joints of the limestone and establishing underground reservoirs and channels for waters which sink into this formation from the overlying drift deposits.

Onondaga limestone. - The Onondaga limestone is considered by far the most important source of underground water. The great area of its outcrop in the west-central and northern portions of the State, as well as the thickness of the formation and its soluble character, furnish the basis for this estimate. A considerable number of cities and villages depend upon this limestone for water supply.

Corniferous limestone.--The Corniferous limestone is considered of small importance as a source of water because of its comparatively small area of outcrop. Several flowing wells in the city of Columbus have, however, been obtained from it, and there are numerous springs issuing from it along the Scioto Valley.

Logan sandstone.-The Logan sandstone is a water-bearing stratum wherever found at the surface. It outcrops prominently in Richland, Ashland, and Wayne counties. Artesian wells have been obtained from it at several points in Wayne County, and the water supply of Orrville is from this source.

Berea grit.-The Berea grit is also a good water bearer along the line of its outerop and often affords supplies when covered by the Cuyahoga shale to moderate depths. Such is the case at the village of New London.

Coal Measures.--The Conglomerate Coal Measures contain a white and pebbly sand of great purity - the Sharon conglomerate-which in its outcrop in northeastern Ohio affords excellent wells. The city of Massillon now derives its supply from this source. Cuyahoga Falls also stands on this conglomerate and the wells of the village are largely obtained in it. 
The water supply of the Coal Measures proper is rather inferior. Excellent water can be secured almost everywhere, but it is considered doubtful if the supply will be adequate for the growing towns that are located within the boundaries of this formation. It is probable that the streams of the region will need to be drawn upon for public water supply.

Drift.-The glacial deposits furnish by far the largest amount of potable water to be obtained within the State. These deposits cover nearly three-fourths of the State, the southeastern portion only being unglaciated. The valley gravels have been carried down the main valleys of the driftless portion of the State and hold much of the water of the valley drainage at convenient depth for wells; the quality of water is generally excellent. The Illinoian drift sheet extends beyond the Wisconsin only in a few counties in the central and southwestern parts of the State. This drift sheet is composed largely of clayey material except along the line of pre-Glacial valleys, where there is found to be a large filling of sand or coarser water-bearing material. Within the limits of the Wisconsin drift the moraines are usually composed in large part of gravelly or sandy material, but in some cases wells have to be sunk to considerable depth to strike strong water veins. On the plains between the moraines beds of sand and gravel are usually found sandwiched between beds of clay or till at convenient depth. Throughout the greater part of the drift-covered portion of the State good wells are obtained at depths of 50 feet or less, and there are only a few localities in which it is necessary to sink to depths of 100 feet or more. There are, however, localities in which strong supplies are obtained at moderate depth, and yet borings have been sunk 100 feet in order to obtain flowing wells.

Much of the surface portion of the drift is a clayey material which protects wells obtained in underlying deposits from surface contamination. Even the areas covered by great glacial lakes in the northwest part of the State have usually. a clayey soil, the principal exception being a belt of sand north of Maumee River in Fulton and Lucas counties. The relation of wells to drift formations may be seen by reference to the map, Pl. XVIII.

\section{LOCALITIES FAVORABLE FOR ARTESIAN WELLS.}

Artesian wells from rock formations are comparatively rare, although the water is usually under considerable hydrostatic pressure. Orton calls attention to strong flowing wells near Orrville obtained from the Logan conglomerate or sandstone and to flows at Massillon from the Sharon conglomerate and to a few others at points scattered over the State. There appears to be no extensive areas of artesian water open to development in the State from any of the rock formations. The glacial deposits are a much more productive field for exploration. 
Flowing wells have been obtained without entering the rock in a belt on the inner slope of the great morainic system that runs from southeastern Michigan across northwestern Ohio into Indiana. Hundreds of wells have already been obtained in Williams, Defiance, and Fulton counties. The wells range from shallow fountains, differing but little from boiling springs, in which pipes are driven only 10 to 20 feet into the ground up to borings nearly 200 feet in depth. In much of that region the thickness of the drift is 150 to 200 feet or more. Flowing wells are also found along the line of deep pre-Glacial channels in Allen, Auglaize, and Mercer counties at depths rànging from 100 feet or less up to 350 feet, and wells have in some cases been continued to depths of more than 400 feet without striking the rock. Records of many of these wells are presented in the report by Orton, mentioned above. There are many other places in Ohio where flowing wells are found in small areas of a square mile or less to which attention has been directed by the author in Monograph XLI. These wells are usually on the iceward slope of moraines, and the region of intake is probably restricted largely to the moraine adjacent to them. They are of various depths, from 20 feet or less up to 100 feet or more. Probably further exploration with deep borings would enlarge such flowing well areas or increase the number of areas in which flows are obtained, for in a great many districts the occurrence of abundant water at moderate depths has freed the residents from the necessity of drilling deeply to test the chances for artesian waters.

\section{MINERAL SPRINGS.'}

Both the drift and the rocks of Ohio yield a considerable number of springs. The springs of the drift vary with the nature of the local materials, but are generally hard and may carry much iron. The rock waters of the Coal Measures are frequently salt or chalybeate, while those of the limestones are generally hard. Many of the springs have been developed as resorts, while others place their water on the market for medicinal or other purposes. Twenty such springs reported sales in 1902, the amount of which aggregated 1,948,840 gallons, with a value of $\$ 172,746 .{ }^{a}$ The springs reporting are as follows:

Alba Spring, Rockfort, Cuyahoga County.

- Arcadian Springs, Mineral Springs, Adams County.

Buckeye Lithia Spring, near Martins Ferry, Belmont County.

Concord Crystal Spring, Concord, Lake County.

Crum Mineral Spring, Austintown, Mahoning County.

Crystal Rock Spring, near Sandusky, Erie County.

Deerfield Mineral Springs, Deerfield, Portage County.

Fargo Mineral Springs, Ashtabula, Ashtabula County.

Green Spring Artesian Mineral Well, Green Springs, Sandusky County.

Knisely Mineral Springs, Bucyrus, Crawford County. 
La Fountaine Springs, Fountain Park, Champaign County.

Magnetic Magnesia Well, Canton, Stark County.

Oakridge Spring, Greensprings, Sandusky County.

Painesville Mineral Spring, Painesville, Lake County.

Puritas Spring, Rockport, Cuyahoga County.

Purtlebaugh Mineral Spring, Urbana, Champaign County.

Rex Ferro-Lithia Springs, New Richmond, Clermont County.

Ripley Brom-Lithia Springs, Ripley, Brown County.

Talewanda Mineral Springs, near College Corner, Preble County.

Wheeler Mineral Springs, Youngstown, Mahoning County.

\section{PRINCIPAL PUBLICATIONS.}

Mineral springs of the United States, by A. C. Peale: Bull. U. S. Geol. Survey No. 32, pp. 130-134.

Preliminary list of deep borings in the United States, pt. 2, by N. H. Darton: WaterSupply and Irrig. Paper U. S. Geol. Survey No. 61, pp. 21-28.

Water resources of Indiana and Ohio, by Frank Leverett: Eighteenth Ann. Rept. U. S. Geol. Survey, pt. 4.

Rock waters of Ohio, by Edward Orton: Nineteenth Ann. Rept. U. S. Geòl. Survey, pt 4 . 


\title{
WEST VIRGINIA.
}

\author{
By M. L. Fuller.
}

West Virginia has through a large portion of its area a rugged topography. It is mountainous only in the eastern part, where it borders the Appalachian ridges, but even in the western portion it is so cut by streams with intervening narrow ridges that there is little even moderately level land, except the narrow strips along some of the streams. The conditions are therefore very favorable for springs, which, with spring-fed streams, constitute the main source of water supply over a large part of the State.

Topographically and geologically it may be divided into two distinct belts: (1) The Appalachian Mountain belt, including the Shenandoah Valley, and (2) the Cumberland Plateau.

\section{APPALACHIAN MOUNTAIN BELT.}

This term is here used, as elsewhere in the report, in its broad sense, and includes the area of folded rocks lying between the crystalline rocks of the Piedmont Plateau of Virginia on the east, and the area of gently folded to nearly flat rocks of the Allegheny Plateau on the west. The belt is crossed by the "handle" of West Virginia, and a narrow strip along its whole eastern boundary is included. The rocks are mainly Cambrian, Silurian, and Devonian in age, although a few small areas of Carboniferous rocks are included, especially near the western borders of the belt. The rocks include quartzites, sandstones, shales, and limestones, the latter occurring principally in the Shenandoah Valley at the extreme eastern extension of the panhandle, and as a strip along the western base of the mountain belt. The former belongs to the Cambro-Silurian rocks, and the latter to the Carboniferous.

Except in the Shenandoah and other smaller valleys, this area is thinly inhabited, and small springs constitute the main source of water supply. In the limestone valleys wells are sometimes resorted to, but reliance in the main is placed on cisterns, because of the uncertainty of the occurrence of water in the limestone. A few large springs issue from the limestones, from the more porous sandstones, 
and more rarely from the shales. The waters are often mineralized and of medicinal value, and a considerable number of springs have been developed as resorts. Some of the waters are thermal.

\section{CUMBERTAND PLATEAU.}

The greater portion of the area of the State falls within what may be termed the Cumberland Plateau, which may be considered as entering the State from Kentucky on the south. The plateau does not present an even surface, but has been cut by streams until only narrow-crested ridges remain to represent the original level. In a broad way the slope is to the northwest, away from the mountains, the altitude varying from 3,500 feet at the western base of the mountains to less than 1,000 feet near the Ohio River. The river bottoms are sunk several hundred feet below the upland level. At the northern boundary of the State the Cumberland Plateau merges with the Allegheny Plateau of Pennsylvania.

The rocks belong mainly to the coal-bearing division of the Carboniferous, and are either inclined at a low angle or gently folded. Because of the numerous springs few attempts have been made to obtain water by deep borings, but the wells drilled for oil and gas frequently obtain abundant water, some of which flows in the synclines or under other favorable conditions.

The stratified deposits along Ohio River and some of the other large streams yield good water to shallow wells, but their area is limited.

\section{MINERAT SPRINGS.}

In 1902 nine springs reported sales of mineral water. The total output is stated to be 92,310 gallons and to have a value of $\$ 25,343 .^{a}$ Several of the springs are also developed as resorts.

Capon Springs, Capon Springs, Hampshire County.

Greenbrier Alum Spring, near Lewisburg, Greenbrier County.

Greenbrier White Sulphur Springs, White Sulphur Station, Greenbrier County.

Magnesia Spring, No. 2, near Wheeling, Ohio County.

Manacea Irondale Spring, near Independence, Preston County.

Pence Spring, Pence Springs, Summers County.

Red Sulphur Springs, Red Sulphur Springs, Monroe County.

Triplet Well, Calf Creek, Grant District, Pleasants County.

Webster Springs, Webster Springs, Webster County.

\section{PRINCIPAL PUBLICATIONS.}

Mineral springs of the United States, by A. C. Peale: Bull. U. S. Geol. Survey No. 32 , pp. 69-73.

Preliminary list of deep borings in the United States, pt. 2, by N. H. Darton: WaterSupply and Irrig. Paper U. S. Geol. Survey No. 61, pp. 61-64. 


\section{N D EX.}

A.

Abbeville, La., section from Eldorado, Ark., to _._._._ 184

Absorption, methods and extent of $--20-21$ Addison, Me., spring near, water from, analysis, flow, etc., of 54,56

Adirondack province, New York, extent of

Alabama, artesian systems of _._- 167-169 artesian systems of, map showing

crystalline schists of, artesian water from

mineral springs in

publications on water resources of

springs in _._. $164,165,166,167,168$ wells in _..._. $164,165,167,169$ wells, brine and gas, in

Allegheny Plateau of Maryland, wells in

of New York, extent of

of Pennsylvania, extent of geology

169

116

82

104

105

Analyses, spring water from Maine_ 52-53,

$55-56$

spring water from Vermont___- 63, 64

water of Lake Champlain _....

waters of Illinois________ 254-256

Annona formation in Louisiana and southern Arkansas, character of.

Antrim shales in Michigan, character of .

Appalachian area of Georgia, geology and underground waters of _._._._. 154-155, 156-157

of Maryland, extent and geology of

wells in

of New Jersey, geology and water resources of wells and population in -..

of North Carolina, geology and underground waters of -

of Pennsylrania, extent of _... geology of _._.

of Virginia, geology and underground waters of _._._ 132-133

of West Virginia, geology and water resources of

271

Appalachian Mountains, character of and water conditions in - 39-40

Archimedes limestone in Arkansas, water resources of _._._. 192

Arkadelphia formation in Louisiana and southern Arkansas, character of _. 180

Arkansas, northern, geologic map of_ $\quad 188$ geology of _. mineral springs in _._._._._. 196-197 publications on water resources of relief map of 188 resources of _. $188-189$ sections in _._. 190,193 sections in Louisiana and _._ 183,184 springs in _._. 191 topography of _._. 188 water resources of _.____ 191-197 wells in _._._._._. 191, 192

Arkansas, sonthern, and Louisiana, artesian areas in, map showing

deep-water prospects in; map showing

geology of

water horizons in _....... 181-186

wells in

Aiken, S. C., crystalline floor at, depth to

Artesian conditions in Alabama - 167-169

in Arkansas, northern_._._. 194, 196

in Iowa _._.

in Minnesota

Artesian fiows, essential conditions of _._.

Artesian wells in Alabama in Illinois, localities favorable for _.

in Indiana, localities favorable for

in Missouri _..._._._._._._. 214-215

in Ohio, localities favorable for _.

See also Wells; Wells, deep, etc. Atlanta, Ga., well at._._. 144

well at, depth of ......... 28

Atlantic Coastal Plain. See Coastal Plain.

Auburn, Me., spring near, water from, analysis, flow, etc., of $54,55,56$ 
B.

Baltimore, Md., sections at and near $\quad 120$

Baltimore district, Md., geology of - 120-121 well prospects and water horizons in _... 121-123

Bangor, Me., spring near, water from, flow, use, etc., of _.....

Baraboo, Wis., section from Des Moines, Iowa, to _......

Barre, vt., water system at

Basal sandstone. See st. Croix sandstone.

Batesville sandstone in Arkansas, water resources of .........

Bayley, W. S., paper by, on underground waters of Maine - 41-56

Bedding planes, definition of and effect on passage of water _..............

Berea grit in Ohio, water resources of -

Berea shale of Michigan, water resources of .

Berkey, C. P., on Basal sandstone

Berkshire Valley, Mass., geology and water supply of _.......

Big Salt Spring, Mo., description of _...

Biloxi sand in Mississippi, character and water resources of --

Bingen sand in Jouisiana and southern Arkansas, water resources of _.____ 180, 182-183

Bluehill, Me., springs near, water from, analysis, flow, ete., of _...

Boone chert in northern Arkansas, water resources of

Boston Mountains, Ark., water resources of

Boutwell, J. M., information furnished by

Bowling Green, Mo., springs at

Brine and gas wells in Alabama

Britts, J. H., information furnished by

Brownstown formation in Louisiana and southern Arkansas, thickness of

Brunswick, Me., spring near, water from, analysis, flow, use, etc., of _..._...

Brunswick beds in New Jersey, character of

Buckfield, Me., spring near, water from, analysis, flow, ete., of _.

Buhrstone. See Tallahatta formation.

Buhrstone beds in South Carolina, water horizons in

Burlington, Vt., wells at and near...-

Burlington limestone in Missouri, water resources of

246

227 c.

Page.

Cambrian rocks of Illinois, water resources of _._. 250

of lowa, water resonrces of _.._ 223

of Minnesota, water resources of $\quad 227$

of New York, geology and water resources of _..._._._._ $83-84$

of Pennsylvania, geology and water resources of _._._- 107

of Wisconsin, geology of _-_- 234-236 water resources of -..-- 237-238

See also names of formations.

Cameron, La., section from Locksburg, Ark., to

Cap au Grès, section from Wisconsin River to

Carboniferous rocks of Illinois, water resources of _..._. 251

of Indiana, water resources of 260-261

of Iowa, water resources of _-__ 224

of Pennsylvania, geology and water resources of

See also names of formations.

Castine, Me., wells at $46-47$

Catahoula beds in Louisiana and southern Arkansas, character and water horizons of _._. 180,186

Catchment conditions, discussion of _- 20-24

Catskill province, New York, extent of

Ca verns, solution, occurrence of

Chalk, porosity of

Chamberlin, T. C., on essential conditions of artesian flows

Champlain, Lake, water of, analysis of

Channel, underground, plate showing

springs from -.............

Chesapeake formation in Delaware, character of _........ 111

in Maryland, character of _._ 117

water horizons in _..... 119

in Virginia, character of

water horizons in _._._-_. $\quad 129$

Chester, S. C., well at

Chester sandstone in Illinois, water resources of ...........

in Indiana, water resources of

Chlorine, normal, in waters of Massachusetts

82

251

261

73

Chouteau group in Missouri, springs from

Cincinnati shale in Wisconsin district, occurrence and character of _._.

Circulation in rocks of different types, disenssion of _______-_ 21-24

City supplies. See Public watersupply systems.

Claiborne formation in Louisiana and southern Arkansas, character of ............ 
Clarendon Spring, Vt., water from, analysis of .

Clay, water from, character and amount of -

Clay marl series of New Jersey, subdivisions of

Cleavage, in slate, plate showing

relation of occurrence of underground water to

Clinton beds in Indiana, water re sources of

in Michigan, water resources of

in Ohio, water resources of

Coal Measures, water resources of, in lllinois

water resources of, in Indiana

in lowa

in Ohio

Coastal Plain, character of and water conditions in

of Alabama, geology of

of Georgia, geology and underground waters of _ 153-154, 155

of Maryland, geology of _..._.

114

wells of

117-118

of New Jersey, geology and water supply of _._.__ 97-100 wells and population in _- 101, 102

of North Carolina,cross section of

137 geology and water horizons

in - 136-138

of Pennsylvania, geology and water supply of _._._. 108

of South Carolina, geology of - 146-149 of Virginia, geology of _ _ 127-128 water horizons of _._._. 128-129

see also Gulf Coastal Plain.

Cockfield beds in Louisiana and southern Arkansas, character and water resources of _. 180,185

Coffee sands in Tennessee, geology and water resources of

Coldwater shales in Michigan, water resources of _........

Columbia formation, character of, in Delaware

character of, in Georgia ......

in Maryland ................

in South Carolina

in Virginia

Commercial springs. See Springs, mineral.

Conglomerate, water from, character and amount of

Conglomerate sandstone of Illinois, water resources of ......

Connecticut, faults in, effect of, on underground waters.....

geology and water supply of irrigation in

mineral springs in

publications on water resources of

rainfall in
Page.

Connecticut, springs in water-supply areas in, map showing -

wells in _._._._. $77,78,79,80$

Connecticut Valley, Mass., geology and water supply of__-_ $\quad 71$

Contamination of wells in Georgia $154-157$

of wells in Maine

in South Carolina

Corniferous limestone in Ohio, water resources of _..._-_-_- 267

Cretaceous rocks of Minnesota, occurrence of

of Mississippi, geology and underground waters of _- 172-173

of New Jersey, geology and water resources of

of New York, geology and water resources of

of South Carolina, geology and water horizons of

Crosby, W. O., paper by, on underground waters of Massachusetts and Rhode Island

Crystalline area in Connecticut, geology and water supply of - 78-79

in Delaware, character of rocks of

of District of Columbia, geology

- and water resources of _. 124-125

of New Jersey, geology and water supply of -_-_-_ 95-96 wells and population in.-- 101

of Pennsylvania, geology and water supply of - 106-107

of Virginia, geology and underground waters of

Crystalline rocks of South Carolina, Coastal Plain, depth to..-

See also Pre-Cambrian rocks.

Crystalline schists of Alabama, artesian water from

Cumberland Plateau of Kentucky, water resources and geology of .

of Tennessee, water resources and geology of _..___-_ 199-200

of Virginia, geology and underground waters of _....-.

of West Virginia, geology and water resources of ...--

D.

Dakota sandstone of Iowa, water resources of

Darton, N. H., paper by, on underground waters of Delaware_-_. 111-113

Darton, N. H., and Fuller, M. L., paper by, on underground waters of District of Columbia _..._._._._._. 124-126

paper by, on underground waters of Maryland _..._._. 114-123

IRR $114-05-19$ 
Darton, N. H., and Fuller, M. L., paper by, on underground waters of Virginia____ 127-135

Lelaware, geology of publications on water resources of _................ sections in water horizons in _._._..._._. 111-112 wells and well prospects in

Delthyris shale of Missouri, springs of -

Des Moines, Iowa, section from Baraboo, Wis., to

Devonian rocks of New York, geology and water resources of .-

of Pennsylvania, geology and water resources of

Dip, effect of, on absorption of water relation of outcrop to, flgure showing -

District of Columbia, geology of mineral springs in publications on water resources of

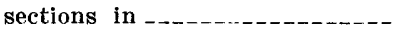
water horizons and prospects of wells in 217

Dolomite, porosity of

Drift in Berkshire Valley, Mass., extent of

in Connecticut, water resources of _- $79-80$

in Illinois, thickness of, map showing -.._._._. 252 water resources of _._._. 251-252

in Indiana, thickness of, map showing _._._. 262

water resources of _._._._. 261-262

in Iowa, water resourres of $-220-222$

in Michigan, lower, water resources of _._.___-_ 242-245

in Minnesota, water resources of _-_._.

in Ohio, thickness of, map showing

water resources of

in Pennsylvania, geology and water resources of

in Wisconsin district, occurrence and character of ......

Drift area, extent of, and water conditions in

Drilled wells. See Wells, drilled.

Dug wells. Sèe Wells, dug.

Dundee limestone in Michigan, water resources of .

Durham, Me., spring at, water from, analysis, flow, etc., of _-_ 52,53

\section{E.}

East Boothbay, Me., spring at, water from, analysis, flow, etc., of
East Orrington, Me, spring near, water from, flow, use, etc., of --_-

East Poland, Me., spring at, water from, analysis and flow of _._._._._. 52, 53

East Tennessee, valley of, water resources of ___-_-_- 198-199

East Turner, Me., spring near, water from, analysis, flow, use, etc., of _-___-____ 51, 52

Eastbrook, Me., spring near, water from, analysis, flow, use, etc., of - -

Eldorado, Ark., section from Abbeville, La., to

Eocene rocks of South Carolina, geology and water horizons of -

See also names of formations.

Eutaw beds in Mississippi, water resources of _..........

Eutaw sand in Alabama, water resources of _-_____- 167-168

Evaporation, discussion of _._._._. 20

F.

Fairfield, Me., spring near, water from, analysis, flow, use, etc., of _._._._._. 51,52

Faults, definition of

effect of, on artesian water_._._ 35

on passage of water._._._ 23

on underground waters of Connecticut_._._.

in Newark system in New Jersey

springs along map showing

Fissure springs, discussion of _-..- 31-32

Flatwoods clay. See Porters Creek clay.

Fleming formation in Louisiana and southern Arkansas, character of

Florence, s. c., crystalline foor at, depth to _.......-

Florida, artesian areas in, map showing -

geology of

mineral springs in publications on water resources of _... 163

springs in

topography of _._._.

underground waters of _._. 160-162

wells in _._.

Flows, artesian, essential conditions of _.

See also Artesian wells, artesian conditions, etc.

Foliation, relation of, to occurrence of ground water......

Fort Ethan Allen, Vt., well at, depth of _- - - 
Fuller, M. L., paper by, on occurrence of ground water

Page.

paper by, on underground waters of Florida 18-40

water 159

on underground waters of

New Hampshire_______ 57-59

on underground waters of

North Carolina_____- 136-139

on underground waters of

Pennsylvania _._._._. 104-110

on underground waters of

West Virginia________ 271-272

Fuller, M. L., and Darton, N. H., paper by, on underground waters of District of Columbia _._._._._._ 124-126

paper by, on underground waters of Maryland _._._-_- 114-123

on underground waters of Virginia 127-135

G.

Galena limestone in Illinois, water resources of _......

Galena-Trenton formation in Iowa, water resources of

in Wisconsin district, occurrence and character of

water resources of

Gardiner, Me., springs near, water from, analysis, flow, use, etc., of

Gas and brine wells in Alabama..-

Gasconade limestone in Missouri, springs from

Georgia, flowing wells in, map showing areas of - 156

geology of

mineral springs in

publications on water resources of -

wêlls in

Geyser springs, discussion of Glacial drift. See Drift.

Glacial till. See Till; Drift.

Glenn, L. C., paper by, on underground waters of South Carolina__._______ 140-152

paper by, on underground waters of Tennessee and Kentucky

198-208

Gneiss, water in

Grand Gulf group in Alabama, ex-

tent of

in Alabama, water resources of _-_..._. 166-167

in Mississippi, water resources of 176-177

Grand Isle, Vt., wells at_______- 64

Granite, porosity of

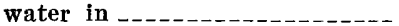

Graydon sandstone in ,Missouri, springs from

Gravel and sand, water from, character and amount of
Greenville, Me., wells at

Page.

Gregory, H. E., paper by, on underground waters of Connecticut

Ground water, occurrence and amount of _._. 24

sources of _______

See also Underground water.

Gulf coast, rainfall along

Gulf Coastal Plain of Kentucky, geology and water resources of _._. 207-208

of Tennessee, water resources of _-_._-___-_ 202-204

H.

Hall, C. W., paper by, on underground waters of Minnesota _-_-_-___._-_- 226-232

Harrison, Me., spring at, water from, analysis, flow, etc., of __- 54, 56

Hatchetigbee formation in Mississippi, water resources of

Henrietta formation in Missouri, water resources of

Highland Plain of Tennessee, water resources of

Holmes, J. A., information furnished by - - -

Fudson group in Indiana, water resources of

in Michigan, water resources of I.

Illinois, artesian wells in, localities favorable for

drift in, map showing thickness of -

geologic column of _-_-_-__- 248-250 geologic map of _._._. 248

mineral springs of _._._._._. 256

publications on water resources of -

water-bearing formations of -- 250-252

waters of, character of ______ 254-256

Impervious rock, spring at outcrop of, plate showing _._._._.

Indiana, artesian wells in, localities favorable for

drift in, map showing thickness of - 262

geologic column of -_-_-_-_-- 258-259

geologic map of _._._._._. 260

mineral springs of

publications on water resources of - 264

water-bearing formations of -- 259-262 Iowa, artesian localities in, map showing - 222

geologic section of mineral springs of publications on water resources of -

rainfall in _..... 20

underground waters of

2

0
4

2


Jackson beds in Louisiana and southern Arkansas, character of

in Mississippi, character of _-_ 176

Johnson, L. C., paper by, on underground waters of Missis. sippi________ 171-178

Johnson, Vt., spring water from, analysis of .

Jointed rock, wells in, supply for, figure showing

Joints, circulation of water along, flgure showing

definition of, and effect on passoge of water

in Newark system of New Jersey _...-._-

openings of, plate showing

springs along, map showing

Jordan sandstone in Iowa, water resources of

in Minnesota, water resources of

\section{K.}

Kentucky, mineral springs in_._-_publicatious on water resources of _.

springs in _._.

water resources and geology of _.

Keweenawan series in Wisconsin district, occurrence and character of -.-.-----

Kingfleld, Me., spring near, water from, analysis, flow, etc., of _-

Kittatinny Valley, N. J., geology and water supply of

Knapp, G. N., paper by, on underground waters of New Jersey _._.

Knobstone formation in Indiana, water resources of

L.

Lafayette formation in Alabama, extent and water resources of _._........

in Georgia, character of

in Maryland, character of

in Mississippi, character of _._ $\quad 177$

in South Carolina, geology of _ 148-149

in Tennessee, geology and water resources of

in Virginia, character of

Lake. See next wold of name.

Lake deposits of Wisconsin district, water resources of

Lakes, public supplies obtained from, in Maine

Lane, A. C., cited on underground waters of Lower Michigan
239
Leverett, Frank, paper by, on underground waters of Illinois

Page.

by, on underground waters

of Indiana__._._._. 258-264

on underground waters of Ohio__________-_ 265-270

Lewiston, Me., spring near, water from, analysis, flow, etc., of _.......

Lexington Plain of Kentucky, water resources and geology of __.___._. 206-207

Lignitic group in Alabama, artesian horizons in _-_._-_ 168-169

in Kentucky, water resources of $\quad 207$

in Mississippi, geology and water horizons of

in Tennessee, geology and water resources of _-_-___-_ 203-204

Limestone, porosity of _______- 23

water from, character and amount of _..........

wells obtaining water from, variation in supply of, figure showing -

Lisbon formation in Alabama, water resources of

Lockatong beds in New Jersey, character of

Locksburg, Ark., section from Cameron, La., to________ 183

Loess in Tennessee, geology and water resources of $\ldots \ldots . .$. .

Logan sandstone in Ohio, water resources of

Long Island, Maine, spring ou, water from, use, etc

Louisiana, mineral springs of publications on water resources of _. 187

sections in

Iouisiana and southern Arkansas, artesian areas in, map showing_.._._._._. 182

deep water prospects in, map showing - 181

geology of

water horizons in

wells in _._._._._._._. 182,183

Jower Helderberg limestone in Indiana, water resources of --

Lower Magnesian limestone in Wisconsin district, occurrence and character of --

in Wisconsin district, water resources of

See also Oneota formation.

Lower Marshall sandstone in Michigan, water resources of.

M.

McCallie, S. W., paper by, on underground waters of Georgia 
Magothy formation in Maryland, character of

in Maryland, water horizons in

Maine, flowing wells in, map showing location of

geology of

lakes used for public supplies in

private supplies in

public supplies in

publications on water resources of

rivers used lor public supplies in

springs in

springs used for public supplies in _.....

topography of

wells in

Maquoketa shale in Iowa, character of _............

Marais des Cygnes shales in Missouri, water resources of.

Marion, S. C., crystalline floor at, depth to

Marl series in New Jersey, subdivisions of -

Marlbrook formation in Louisiana and southern Arkansas, character of

Maryland, publications on water resources of

Page.

117

119

49

41-42

45

$47-56$

$43-47$

56

44

$48-56$

46

41

$6-48$

224

213

146

98

180

123

sections in

118,120

springs in

streams in

topography and geology of _-_ 114-115

water horizons in _._._._. 118-120

wells in

Massachusetts, geology of Rhode Island and

68-69

mineral springs in

68-69

principal publications on water resources of _._._._.

water-supply areas in Rhode Is-

land and

waters of, normal chlorine in

Matawan formation in Delaware, character of .........

Medina beds in Indiana, water resources of -

Michigan, lower, geologic map of

publications on water resources

of

73

111

260

243

section across................

topography and geology of .....

underground waters of

Michigan series in Michigan, water resources of

Midway beds in Louisiana and southern Arkansas, eharacter of

in Mississippi, character of

Mineral springs. See Springs, mineral.

Minnesota, artesian basin in, map showing

247

244

242

$-247$

246

180

174
Minnesota, artesian basins in. ... 228 280 publications on water resources of _. 232

rainfall in

springs in _._._._._._. 231-232

water resources of

wells in

Missisquoi Spring, vt., water from, analysis of

Mississippi, geologic map of geology and underground waters

of -

mineral springs of

publications on water resources of _.

springs in _...

$173,174,175,176,177-178$

wells in

$172,173,174,175,176,177$

Mississippi delta, rainfall in

Mississippi-Great Lakes basin, character of and water conditions in

Mississippian rocks of Mississippi, geology and water resources of

See also names of formations.

Missouri, artesian wells in _._._. 214-215

geologic map of

geology of _._._._._._. 210

mineral springs of

publications on water resources of _._. 219

section through

springs in $213-214,215,216,217,218,219$

topography of underground waters of.....- 211-218 water resources of, map showing _. wells in _- 211-212, 214, 215, 216, 217

Monroe limestone in Michigan, water resources of _._._._._ $\mathbf{2 4 5}$

Montpelier, Vt., water system at_-_- $\quad 60$

Municipal supplies. See Public water-supply systems.

\section{N.}

Nacatoch sand in Louisiana and southern Arkansas, water resources of _._- $180,183-184$ basin, Tenn., water re sources of - 201

Navesink formation in Delaware, character of _._._. 111

New England, rainfall in 
Page.

New Hampshire, geology of publications on water resources of _...... springs in topography of wells in

New Jersey, geology and water supply of

94-103

mineral springs in

publications on water resources<smiles>[GeH2]=CC#C[Te]</smiles>

sections across southern

topographic provinces of _-____ 93-94

underground water areas in, map showing _.........-

wells in Coastal Plain, statistics of _.

New Richmond sandstone in Minnesota, water resources of -

in Wisconsin, correlation of

New York, geology and underground waters of

map showing geologic areas and spring localities in

mineral springs of

physiography of

$87-91$

publications on water resources of -

springs in $83,84,85,86,87$

wells in

Newark area of New Jersey, geology and water supply of

Niagara limestone in Illinois, water resources of _._._-__- 250,267

in Indiana, water resources of

in Michigan, water resources of

in Wisconsin district, occurrence and character of _-_. 236-237

Nobleboro, Me., spring near, water from, analysis, flow, etc., of _.

Normal chlorine in waters of Massachusetts

North Carolina, geolngy and water horizons of 136-139

mineral springs of

publications on water resources of -

rainfall in 20

wells in Coastal Plain region_ 137-138

Northeast Harbor, Me., spring near, water from, flow, use, etc., of

Norton, W. H., paper by, on underground waters of Iowa_ 220-225

Norway, Me., spring near, water from, flow, use, etc., of

\section{o.}

Ohio, artesian wells in, localities favorable for _._._._-_ 268-269

drift in, map showing thickness of
Ohio, geologic column in

Page.

geologic map of

publications on water resources of ........ 270

mineral springs in underground water in, charac-

teristics of _- 266

water-bearing formations in - 266-268

wells in

Oneota formation in Iowa, water resources of - 228

in Minnesota, water resources of 227

Onondaga limestone in Ohio, water resources of 267

Ontario province, New York, extent of

Orangeburg, S. C., crystalline floor at, depth to

Ordovician rocks of Arkansas, northern, water resources of _- 191

of Iowa, water resources of _- 223-224 of Minnesota, water resources of _._._-______-_ 227-228

of New York, geology and water supply of _-_-_._-_-_-_ 84-85

See also names of formations.

Orton, Edward, on waters of Ohio_. $\quad 260$ Ozark-St. Francis Dome, Mo., water resources of _..._-_. $216-218$

P.

Paleozoic rocks in Arkansas, northern, water resources of 191-195

in Georgia, geology and underground waters of -.-- 154-155,

156-157

in Louisiana and southern Arkansas, character of -.--

see also names of formations.

Pamunkey formation in Delaware, character of ..........

in Maryland, character of ..... water resources of

in Virginia, character and water resources of _-

Parma sandstone in Michigan, water resources of

Pennsylvania, geologic subdivisions of, figure showing -..-- 105

geology of _.

mineral springs in _._._._._. 109

publications on water resources of _... 110

streams and lakes in

topography of ....... 104

wells in - 106-108

Pentremital limestone in Arkansas, water resources of

Perkins, G. H., paper by, on underground waters of Vermont _._-

Permeability of rocks, discussion of - 21-24 Piedmont Plateau, character and water resources of 
Piedmont Plateau of Georgia, geology and underground waters of _..........-

of Maryland, extent and geology of -

wells in _._.

of New Jersey, geology and water resources of _-____- 96--97

wells and population in _- 101, 102

of North Carolina; geology and underground water of _-_ 138

of Pennsylvania, extent of _._._ 104

geology of _..._..._. 104-105

of South Carolina, geology and water resources of

of Virginia, geology and underground waters of _.....-

Pine Point, Me., spring near, water from, flow, use, etc., of --

Pittsfleld, Me., spring near, water from, flow, use, etc., of --

Poland, Me., spring near, water from, analysis, flow, etc., of - 52, 54, 56

Pollution. See Contamination.

Pontchartrian clay in Mississippi, character and water resources of

Porosity, relation of, to occurrence of ground water

Port Hudson group in Mississippi, character and water resources of -...-_..-_.

Porters Creek clay in Kentucky, geology and water resources of _.............

in Tennessee, water resources of

Portland, Me., spring 63 miles from, water from, analysis, flow, etc., of _...-.

Potomac formation in Delaware, character of

in District of Columbia, geology and water resources of_ $125-126$

in Maryland, water horizons in _..._ 118-119, 120, 121, 122

in North Carolina, occurrence and character of _._._. 136-137

in South Carolina, geology and water horizons of _--- 146-147

in Virginia, character of and water horizons in

Potsdam sandstone in Illinois, water resources of _.......-.

in Wisconsin district, occurrence and character of --_-- 234-235 water resources of

porosity of _- 23

Pre-Cambrian rocks of New York, geology and water supply of -

of Wisconsin-district, occurrence and character of

See also Crystalline rocks.

Precipitation, See Rainfall.

83
Public water-supply systems in

$$
\text { Maine - }
$$

in Vermont

60-62

Pumps, kinds of

Purdue, A. H., paper by, on underground waters of northern Arkansas _._._-_ 188-197

\section{Q.}

Quartzite, water from, character and amount of

Quaternary rocks of Mississippi, geology and water horizons of _........-.

of New York, geology and water supply of Se also Drift.

$\mathbf{R}$.

Rainfall, amount of

disposal of _. $20-21$

in Connecticut _... $\quad \mathbf{7 6}$

in eastern United States, figure showing

in Tennessee

in Vermont..... 60

relation of run-off to

Rancocas formation in Delaware, character of

. Raritan formation in Delaware, character of _........

in New Jersey, character of Redbank formation in Delaware, character of -..--

Red River Valley, Minn., artesian conditions in _..._-_.-- 230

Rhode Island, geology of Massachusetts and

mineral springs in

publications on water resources of -

water supply areas in Massachusetts and

111

111

Ripley formation in Alabama, water resources of

168

in Kentucky, geology and water resources of

in Mississippi, water resources of

in Tennessee, geology and water resources of

207

173

203

Rivers, public supplies obtained from, in Maine.

Rocks, permeability and storage capacity of _._. 21-24

Rocks, water-bearing, discussion of - 25-28 Rotten limestone in Tennessee, geology and water resources of

203

See also Selma chalk.

Run-off, relation of rainfall to 
S.

Sabine group in Jouisiana and southern Arkansas, character and water resources of

Saco, Me., spring near, water from, analysis, flow, etc., of - 51, 54, 55

Saginaw Valley, Mich., underground water's in ..............

St. Albans, Me., spring near, water from, analysis, flow, etc., of -- - - -

St. Croix sandstone in Iowa, water resources of ...........

St. Louis limestone in Illinois, water resources of

in Indiana, water resources of -

St. Peter sandstone in 1llinois, water resonrces of

in Indiana, water resources of

in Iowa, water resources of -...

in Minnesota, water resources of _._.

in Missouri, water resources of _

213 ,

$214,215,216$

in Wisconsin district, occurrence and character of outcrop of, map showing water resources of _........

Salina beds in Michigan, water resources of

Salt springs in Missouri

Salt water, origin of

Sand, porosity of

Sand and gravel, water from, char acter and amount of

Sandstone, porosity of

water from, character and amount of

view of, under microscope

Schistosity, relation of, to occur rence of ground water...

Schists, water in

Schultz, A. R., paper by, on underground waters of Wiscon sin district___._._. 233-241

Sea water, ground water derived from

Seepage, recovery of underground water by

29-30

Seepage springs, discussion of _..._. $\quad 30$

Selma chalk in Mississippi, occurrence of

Severn formation in Maryland, character of

Shakopee formation in Minnesota, occurrence of -

Shepard, E. M., paper by, on underground waters of Missouri 209-219

Silurian rocks of New York, geology and water supp!y of _-_- 85-86

of Pennsylvania, geology and water supply of

See also names of formations.

107 See also Solution caverns.

Slate, cleavage in, plate showing ---water from, character and amount of _.........

Smith, E. A., paper by, on underground waters of Alabama _._.

Solution caverns, relation of, to occurrence of ground water

South Britain, Conn., springs along faults or joints near, map showing

South Carolina, geology and water horizons of _..._-__-_ 140-152 publications on water resources of - 152

sections in eastern_._._. 148 springs in__._._._._._. 141-142 streams in subdivisions and climatic features of _-_ 140

wells in _._._._._. 142-145, 149-152

South Poland, Me., spring at, water from, analysis, flow, etc., of _...... 54,56

Spaulding well, Mo., description of _- 215

Spring at outcrop of impervious rock, plate showing

Spring water, analyses of, from Maine________ 52-53, 55-56 analysis of, from Vermont_-_-- 63, 64 Springs, occurrence and character of, in Alabama ... 164, $165,166,167,168$

occurrence and character of, in Arkansas, northern _._. 191

in Connecticut_..... $78,80-81$

in Florida_._... 161, 162-163

in Kentucky_._._. 206, 207, 208

in Maine _._._._._._. $48-56$

in Maryland

in Minnesota

in Mississippi $173,174,175,176,177-178$

in Missouri__. 212, 213-214, 215, 216, 217, 218, 219

in New Hampshire

in New York _- 83, 84, 85, 86, 87-91

in South Carolina _._._. 141-142

in Tennessee_._._._._. 199 , $200,201,202,203,204,205$

in Vermont

in Wisconsin district__._. 239-241

public supplies obtained from,

in Maine

recovery of underground waters by means of :-_._. 30-32

Aee also Springs, mineral. mineral. 
Springs, mineral, analyses of water from, of Vermont occurrence of, in Alabama

in Arkansas _..

in Connecticut_..... 80-81

in District of Columbia

in Florida_._._-_._-_ 162-163

in Georgia_._._. 157

in Illinois_._._._. 256

in Indiana _._._._- 263-264

in Iowa_........... 225

in Kentucky _... 208

in Louisiana____._._._- 186

in Massachusetts ______ $73-75$

in Michigan, lower_____ 246-247

in Mississippi_._._._-_ 177-178

in Missouri _._._-____- 219

in New Jersey

in New York _._______ 87-91

in North Carolina______ 139

in Ohio _._._-_._-_ 269-270

in Pennsylvania

in Rhode Island_._._._. 75

in Tennessee._...... 205

in Vermont

in Virginia _._._._._. 133-134

in West Virginia _._._. 272

in Wisconsin district._. 240-241

see also Springs.

Stockton beds in New Jersey, character of

Storage capacity of rocks. See Permeability.

Stream deposits in Pennsylvania, water supply of

Streams in South Carolina, water supply obtained from 145,152

run-off of, relation of rainfall to 20

Strong, Me., spring near, water from, analysis, flow, etc., of $--54,56$

Sucarnochee formation in Mississippi, character of

T.

Taconic province, New York, extent of _._.

Tallahatta formation in Mississippi, water resources of ._._.

Temperature of underground waters, discussion of _-______ 28-29

Tennessee, mineral springs in publications on water resources of

Tuscaloosa formation in Alabama,

rainfall in 20,198 springs in in --199 , topography of $--198,199,200-201,202$ valley of East, water resources of ___ 198-199 water resources of 199, 200, 201-202, 203-205 wells in 203,204
Triassic rocks, geology and water resources of, in New York

geology and water supply of, in Pennsylvania_.........

in Virginia _..........

'Triassic sandstone, porosity of of Connecticut Valley, geology and water supply of water from, character of

in Mississippi, water resources of -

U.

Page.

202 195-196

261 174-177

Underflow, lines of, figure showing-Underground channel, plate showingsprings from Underground water conditions in discussion of _._._-_- 35-40

Underground waters, occurrence of $-18-40$ recovery of _._._.______ 29-34 temperature of _._-_._-_-_-_- 28-29 See also Ground water.

Upper Marshall sandstone. See Napoleon sandstone.

Utica shales in Michigan, water resources of _.........eastern United States, 
v.

Vaughan, T. W., information furnished by

Veatch, A. C., paper by, on underground water of Louisiana and southern Arkansas _._-__-____- 179-187

Vermont, drift, water-bearing, of, map showing_-_-_-_-_-_

lakes and ponds in

mineral springs in 65-66

publications on water resources of

public supplies in.

springs in

topography and geology of 60-62 62-64

Vicksburg formation in Louisiana and southern Arkansas, character of _..._._.

in Mississippi, character of

Vienna, Me., spring near, water from, analysis, flow, use, ete., of _..._.

Village supplies. See Public water supply systems.

Virginia, mineral springs in 133-134 physiographic divisions of _-_-- 127 publications on water resources of _sections in eastern_._._._. 128 wells in coastal plain of $\ldots+\ldots 120-131$

w.

Water, salt. See Salt water.

Water, sea. See Sea water.

Water, spring. See Spring water.

Water, underground. See Underground water.

Water-bearing formations, discussion of -

features of, figures showing

Water supply. Sec Public watersupply systems.

Waterlime beds in Indiana, water resources of

Waterville, Me., spring near, water from, analysis, flow, use, etc., of -

Waverly shale in Indiana, water resources of -

Weathered rocks, occurrence of water in., paper by, on under-

Weeks, F. B., paper by, on underYork_________.__ 82-92

Wells at Atlanta, Ga., character of _- 28

Weils, contamination of, in Georgia 154,157 contamination of, in Maine - $\quad 48$

Wells, in South Carolina

in limestone, variations in, flgure showing ..........

kinds of, description of
Wells, occurrence and character of, in Alabama - 164, 165, 167, 169 occurrence and character of, in

Arkansas, northern_.._ 191, 192

in Arkansas, southern, and

Louisiana _._._._._. 182, 183

in Connecticut _... $77,78,79,80$

in Delaware

in District of Columbia

in Florida _.

in Georgia _._. 154

in Louisiana and southern

Arkansas . . . . . _ _ 182, 183

in Maryland _._._._. 116-119, $121,122,123$

in Minnesota

in Mississippi_.._. 171 , $172,173,174,175,176,177$

in Missouri _._._._- 211-212, $214,215,216,217$

in New Hampshire _..._. 58

in New Jersey _._._._._. 98-102

in New York__-_- 83, 84, 85, 86

in North Carolina, Coastal

Plain region of -...-- 137-138

in Ohio _._. 269

in Pennsylvania _._._. 106-108

in South Carolina_..... 142-145,

149-152

in 'Tennessee -

in Vermont

in Virginia,Coastal Plain_ 129-131

See also Wells, artesian; Wells, deep, etc.

Well, artesian, plate showing _._._- 30

Welts, artesian, in Alabama_._- 165

in Illinois, localities favorable for

in Indiana, localities favorable for - 262

in Missouri

in Ohio, localities favorable for -

See also Wells; Artesian conditions; Artesian fiows.

Wells, bored, kinds of

Wells, deep, in South Carolina_..._. 143-

145,152

in Vermont

Wells, drilled, in Maine _._._._ 46-47, 48

kinds of

relative size and capacity of dug wells and, figure showing

Wells, driven, character and advantages of

Wells, dug, character and advantages of -

relative size and capacity of drilled wells and, figure showing - 26

Wells, open, in South Carolina

Wells, shallow, in Alabama_._. 164

in South Carolina..... 151-152 
INDEX.

West Hancock, Me., spring near, water from, analysis, flow, use, etc., of _.__-_ 54,55

West Pownal, Me., spring near, water from, analysis, flow, etc., of _.__ 54,55

West Scarboro, Me., spring near, water from, flow, use, etc., of

Page.

West Virginia, mineral springs of . publications on water resources of underground waters of $271-272$

Wilmington, S. C., crystalline floor at, depth to

Wisconsin district, geology of - 234-237 mineral springs of
Wisconsin district, publications on water resources of Potsdam and St. Peter sandstones in, map of outcrop of - 235

section in 233

springs in

topography of

underground waters of _._._. 237-241

Wisconsin River, section from Cap au Grès to_.........- 253

Z.

Zircon, Me., spring at, water from, analysis, flow, etc., of_-- 54,55 


\section{LIBRARY CATALOGUE SLIPS.}

[Mount each slip upon a separate card, placing the subject at the top of the second slip. The name of the series should not be repeated on the series card, but the additional numbers should be added, as received, to the first entry.]

\section{Fuller, Myron L[eslie] I873-}

... Underground waters of eastern United States.

Myron L. Fuller, geologist in charge. Washington, Gov't print. off., I905.

285 p., 11. illus., XVIII pl. (incl. maps) 23 $3^{\mathrm{cm}}$. (U. S. Geological survey. Water-supply and irrigation paper no. 114)

Subject series: O, Underground waters, 31 .

Includes papers by M. L. Fuller, W. S. Bayley, G. H. Perkins, W. O. Crosby, H. E. Gregory, F. B. Weeks, G. N. Knapp, N. H. Darton, L. C. Glenn, S. W. McCallie, E. A. Smith, L. C. Johnson, A. C. Veatch, A. H. Purdue, E. M. Shepard, W. H. Norton, C. W. Hall, A. R. Schultz and F. Leverett.

Bibliographies at end of articles.

1. Water, Underground-U. S.

\section{Fuller, Myron L[eslie] 1873-}

... Underground waters of eastern United States.

Myron L. Fuller, geologist in charge. Washington, Gov't print. off., I905.

285 p., 11. illus., XVIII pl. (incl. maps) $23^{\mathrm{cm}}$. (U. S. Geological survey. Water-supply and irrigation paper no. 114)

Subject series: O, Underground waters, 31.

Includes papers by M. L. Fuller, W. S. Bayley, G. H. Perkins, W. O. Crosby, H. E. Gregory, F. B. Weeks, G. N. Knapp, N. H. Darton, L. C. Glenn, S. W. McCallie, E. A. Smith, L. C. Johnson, A. C. Veatch, A. H. Purdue, E. M. Shepard, W. H. Norton, C. W. Hall, A. R. Schultz and F. Leverett.

Bibliographies at end of articles.

1. Water, Underground-U. S.

U. S. Geological survey.

Water-supply and irrigation papers.

no. I I4. Fuller, M. L. Underground waters of eastern United States. I905.

U. S. Dept. of the Interior.

see also

U. S. Geological survey. 
WS 1. Pumping water for irrigation, by H. M. Wilson. $1896.57 \mathrm{pp}, 9 \mathrm{pls.}$

WS 8. Windmills for irrigation, by E. C. Murphy. 1897 . $49 \mathrm{pp}, 8$ pls.

WS 14. New tests of certain pumps and water lifts used in irrigation, by O. P. Hood. 1898. $21 \mathrm{pp}_{4}$ $1 \mathrm{pl}$.

WS 20. Experiments with windmills, by T. O. Perry. $1899.97 \mathrm{pp}, 12 \mathrm{pls.}$

WS 29. Wells and windmills in Nebraska, by E. H. Barbour. 1899.85 pp., 27 pls.

WS 41. The windmill; its efficiency and economic use, Pt. I, by E. G. Murphy. 1901.72 pp., 14 plg.

WS 42. The windmill, Pt. II (continuation of No. 41). 1901. 75-147 pp., 15-16 pls.

WS 91. Natural features and economic development of Sandusly, Maumee, Muskingum, and Miami drainage areas in Ohio, by B. H. Flynn and M. S. Flynn. 1904.130 pp.

\section{SERIES L-QUALTTY OF WATER.}

WS 3. Sewage irrigation, by G. W. Rafter. 1897. 100 pp., 4 pls.

Ws 22. Sewage irrigation, Pt. II, by G, W. Rafter. 1899.100 pp, 7 pls.

WS 72. Sewage pollution near New York City, by M. O. Leighton. 1902.75 pp., 8 pls.

WS 76. Observations on flow of rivers in the vicinity of New York City, by H. A. Pressey. 1903. 108 pp., 13 pls.

WS 79. Normal and polluted waters in northeastern United States, by M. O. Leighton. $1903.192 \mathrm{pp}$. WS 103. Review of the laws forbidaing pollution of inland waters in the United States, by E. B. Goodell. 1904. $120 \mathrm{pD}$.

WS 108. Quality of water in Susquehanna drainage basin, by M. O. Leighton. 1904.76 pp., 4 pls. WS 113. Strawboard waste, its damage to water resources and its economic disposal. 1905. 52 pp., 4 pls.

\section{SERIES M-GENRRAL HYDROGRAPHIC INVERTIGATIONS.}

WS 56. Methods of stream measurement. 1901. $61 \mathrm{pp} ., 12 \mathrm{pls}$.

WS 64. Accuracy of stream measurements, by E. C. Murphy. 1902. 99 pp., 4 pls.

WS 76. Observations on the How of rivers in the vicinity of New York City, by H. A. Pressey. 1903. $108 \mathrm{pp} ., 13 \mathrm{pls}$

WS 80 . The relation of rainfall to run-of, by G. W. Rafter. $1903.104 \mathrm{pp}$.

WS 81. California hydrography, by J. B. Lippincott. $1903.488 \mathrm{pp}, 1 \mathrm{pl}$.

WS 88. The Passaic flood of 1902, by G. B. Hollister and M. O. Leighton. 1903,56 pp., 15 pls.

WS 91. Natural features and economic development of Sandusky, Matumee, Muskingum, and Miami drainage areas in Ohio, by B. H. Flynn and M. S. Flynn. 1904.130 pp.

WS 92. The Passaic thood of 1903 , by M. O. Leighton. 1904. 48 pp., 7 pls.

WS 94. Hydrographic manual of United States Geological Survey, by E. C. Murphy, J, C. Hoyt, and G. B. Hollister. 1904. 76 pp., 3 pls.

WS 95. Accuracy of stream measurements (second edition), by E. C. Murphy. 1904. 169 pp., 6 pls WS 96. Destructire floods in the United States in 1903, by E. C. Nurphy. 1904.81 pp., 13 pls. WS 106. Water resources of the Philadelphia district, by Florence Bascom. 1904.75 pp., 4 pls. WS 109. Hydrography of Susquehanna River drainage basin, by J. C. Hoyt and R. H. Anderson. 1905. 215 pp., 28 pls.

SERIES N-WATER POWER.

WS 24. Water resources of State of New York, Pt. I, by G. W. Rafter. 1899.92 pp., 13 pls.

WS 25. Water resources of State of New York, Pt. II, by G. W. Rafter. $1899.100-200$ pp., 12 pls.

WS 44, Profles of rivers, by Henry Gannett. 1901 , 100 pp., 11 pls.

WS 62. Hydrography of the Southern Appalschian Mountain reglon, Pt. I, by H. A. Pressey. 1902, $95 \mathrm{pp}, 25 \mathrm{pls}$

WS 63. Hydrography of the Southern Appalachian Mountain region, Pt. II, by H. A. Pressey. 1902. 96-190 pp., 26-44 pls.

WS 69. Water powers of the State of Maine, by H. A. Pressey. 1902. 124 pp., 14 pls.

WS 105. Water powers of Texas, by T. U. Taylor. 1904.116 pp., 17 pls.

Ws 107. Water powers of Alabama and stream measurements in Mississippi, by B, M. Hall. 1904. 253 pp., 9 pls.

WS 109. Hydrography of Susquehanna River drainage basin, by J. C. Hoyt and R. H. Anderson. 1905. 215 pp., 28 pls.

IRR $114-8$

[Continued on fourth prge of cover.] 
WS 4. A reconnaissance in southeastern Washington, by I. C. Russell. 1897.96 pp., 7

WS 6. Underground waters of southwestern Kansas, by Erasmus Haworth. 1897. 65 I

WS 7. Seepage waters of northern ttah, by Samuel Fortier. 1897.50 pp., 3 pls.

Ws 12. Undergronad waters of southeastern Nebraska, by N. H. Darton. 1898 . 56 pp.,

WS 21. Wells of northern Indiana, by Fraak Leverett. 1899. $\$ 2$ pp., 2 pls.

Ws 26. Wells of soutbern Indiana (continuation of No. 21). by Frank Leverett. 1899.

WS 30. Water resourcus of the Lower Peninsula of Michigan, by A.C. Lane. 1899. 971

WS 31. Lower Miehigan mineral waters, by A. C. Lane. $1899.97 \mathrm{pp.,} 4 \mathrm{pls}$,

WS 34. Geology and water resources of a portion of sontheastern South Dakotr, by J. E $34 \mathrm{pp}, 19$ pls.

WS 53. Geology and water resources of Nez Perces County, Idaho, Pt. I, by I. C. Russe pp. $10 \mathrm{pls}$.

WS 54. Geology and water resources of Nez Perces County, Idaho, Pt. II, by I. C. R 87-141 pp.

WS 55. Geology and water resources of a portion of Yakima County, Wash., by G. O. Smi pp., 7 ple.

WS 57. Preliminary list of deep borings in the United States, Pt. I, by N. H. Darton. 1

Ws 59. Development and application of water in soutbern California, Pt. I, by J. B 1902. 95 pp.y 11 pls.

WS 60. Development and application of water in southern California, Pt. I, by J. I 1902. $96-140 \mathrm{pp}$.

WS 61. Preliminary list of deep borings in the United States, Pt. II, ly N, H. Darton.

WS 67. The motions of underground waters, by C. S. Slichter. $1902.106 \mathrm{pp}, 8 \mathrm{pls}$

B 199. Geology and water resourees of the Snake River Plains of Idaho, by I. C. Russe pp., 25 pls.

WS 77. Water resonrces of Molnkai. Hawaiian Islands, by Waldemar Lindgren, 1903.

WS 78. Preliminary report on artesian busins in southwestern Idaho and southeaster I. C. Russell. $1908.53 \mathrm{pp}, 2$ pls.

PP 17. Preliminary report on the geology and water resonrces of Nebraska west of the and third meridian, by N. H. Darton. $1903.69 \mathrm{pp}, 43 \mathrm{pls}$.

WS 90. Geology and water reeources of part of the lower James River Valley, South Da Tođd and C. M. Hall. 1904.47 pp, 29 pls.

WS 101. Underground waters of southern Louisians, by G, D. Harris; with discussions of water supplies and for rice irrigation, by M. L. Fuller, 1904. 98 pp., 11 pls.

WS 102. Contributions to the hydrology of eastern tinited States, 1993, by M. L. Fuller.

Wg 104. Underground waters of Gila Valley, Axizona, by W. T. Lee. $1904.71 \mathrm{pp}$, 5 pls.

WS 106. Water resources of the Philadelphir district, by Florence Bascom. 1904. 75 pF

WS 110. Contributinns to hydrology of eastern United States, 1904, M. L. Fuller, geolog 1905. 211 pp. 5 pls.

PP 32. Geology aad underground water resources of the central Great Plains, by N.H. I 483 pp, 72 pls.

WS 111. Preliminary report on undexground waters of Washington, by Henry Laudes. $1 \mathrm{pl}$.

WS 112. Undertlow tests in the drainage basin of Los Angeles River, by Homer Hamlin. 7 pls.

WS 114. Underground waters of esatern United States, M. L. Fuller, geologist in $r$ - pp., 18 pls.

The following papers also relate to this subject: Underground waters of Arkansas Val Colorarlo, by G. K. Gilbert, in Seventeenth Annual, Pt. I; Preliminary report on artes a. partion of the Dakotas, by N. H. Darton, in Seventeenth Annual, Pt. II; Water resa nois, by Frank Leterett, in Seventeenth Annual, Pt. II; Water resources of Indiana Frank Leverett, in Eighteenth Annual, Pt. IV; New developments in well boring and eastern South Dakota, by N. H. Darton, in Eighteenth Annual, Pt. IV; Rock water Edward Orton, in Nineteenth Annual, Pt. IV; Artesian well prospects in the Atlantic region, by N. H. Darton, Bulletin No. 138.

\section{Sgities P-Hydrographic Progress Reports.}

Progress reports may be found in the following publications: For 1888-89, Tenth \& for 1889-90, Eleventh Annital, Pt. II; for 1890-91, Twelfth Annual, Pt. II; for 1891-92, Thirts Pt. U1; for 1893-94, Bulletin No. 131; for 1895, Bulletin No. 140; for 1896, Eighteeath A1 WS 11; for 1897, Nineteenth Annual, Pt, IV, WS 15, 16; for 1898, Twentieth Annual, Pt. for 1899, Twenty-flrst Annual, Pt. IV, Ws 35-39; for 1900, Twenty-second Annua], Yt. TV, 1901 , WS 65,66 , 75; for 1902 , WS 82-85; for 1903, WS $97-100$.

Correspondence should be addressed to 